
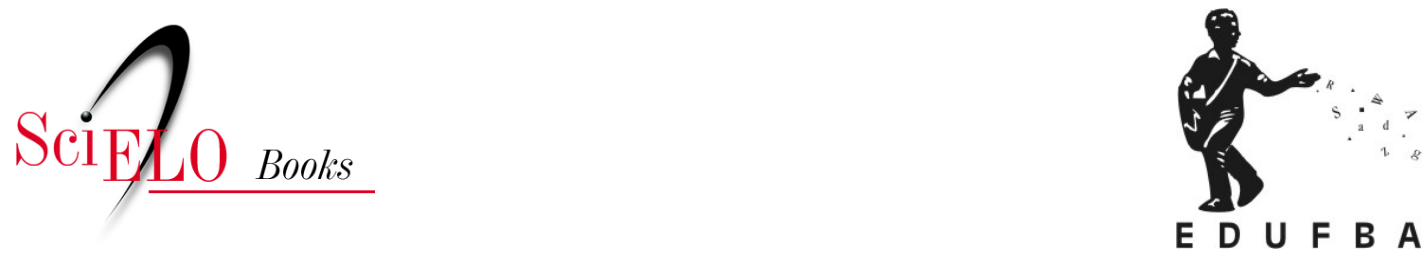

\title{
Comensalidades em Trânsito
}

\author{
Maria Claudia da Veiga Soares Carvalho \\ Fabiana Bom Kraemer \\ Francisco Romão Ferreira \\ Shirley Donizete Prado \\ (orgs.)
}

\section{SciELO Books / SciELO Livros / SciELO Libros}

CARVALHO, M. C. V. S., KRAEMER, F. B., FERREIRA, F. R., and PRADO, S. D., eds. Comensalidades em trânsito [online]. Salvador: EDUFBA, 2020, 307 p. Sabor metrópole series, vol. 11. ISBN: 978-65-5630-177-8. http://doi.org/10.7476/9786556301778.

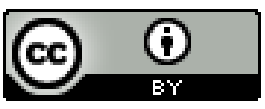

All the contents of this work, except where otherwise noted, is licensed under a Creative Commons Attribution 4.0 International license.

Todo o conteúdo deste trabalho, exceto quando houver ressalva, é publicado sob a licença Creative Commons Atribição 4.0.

Todo el contenido de esta obra, excepto donde se indique lo contrario, está bajo licencia de la licencia Creative Commons Reconocimento 4.0. 

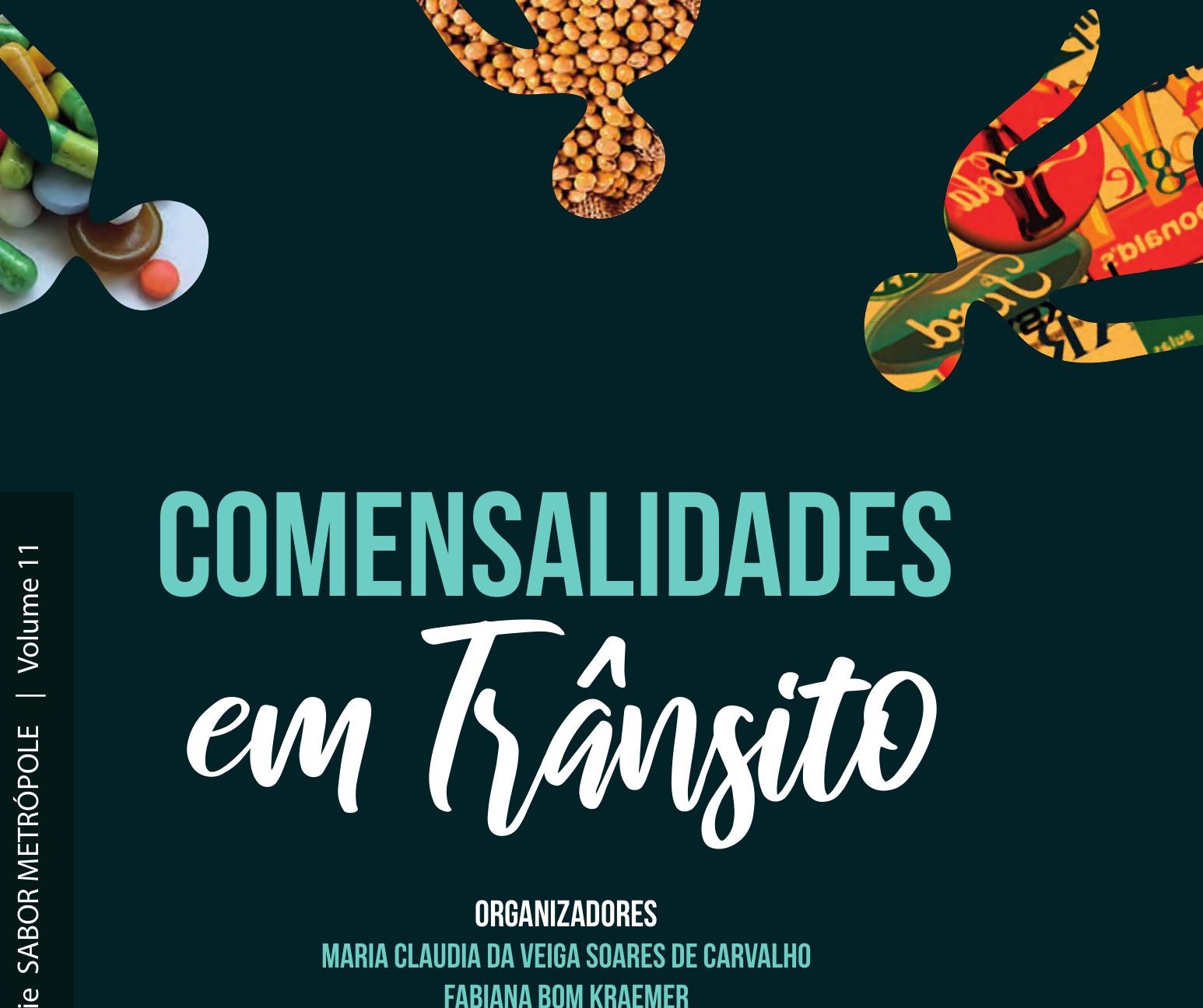

FRANCISCO ROMÃO FERREIRA

SHIRLEY DONIZETE PRADO

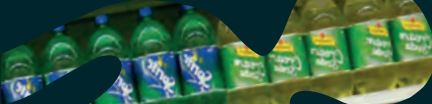

A. $3 \times 3=1=$
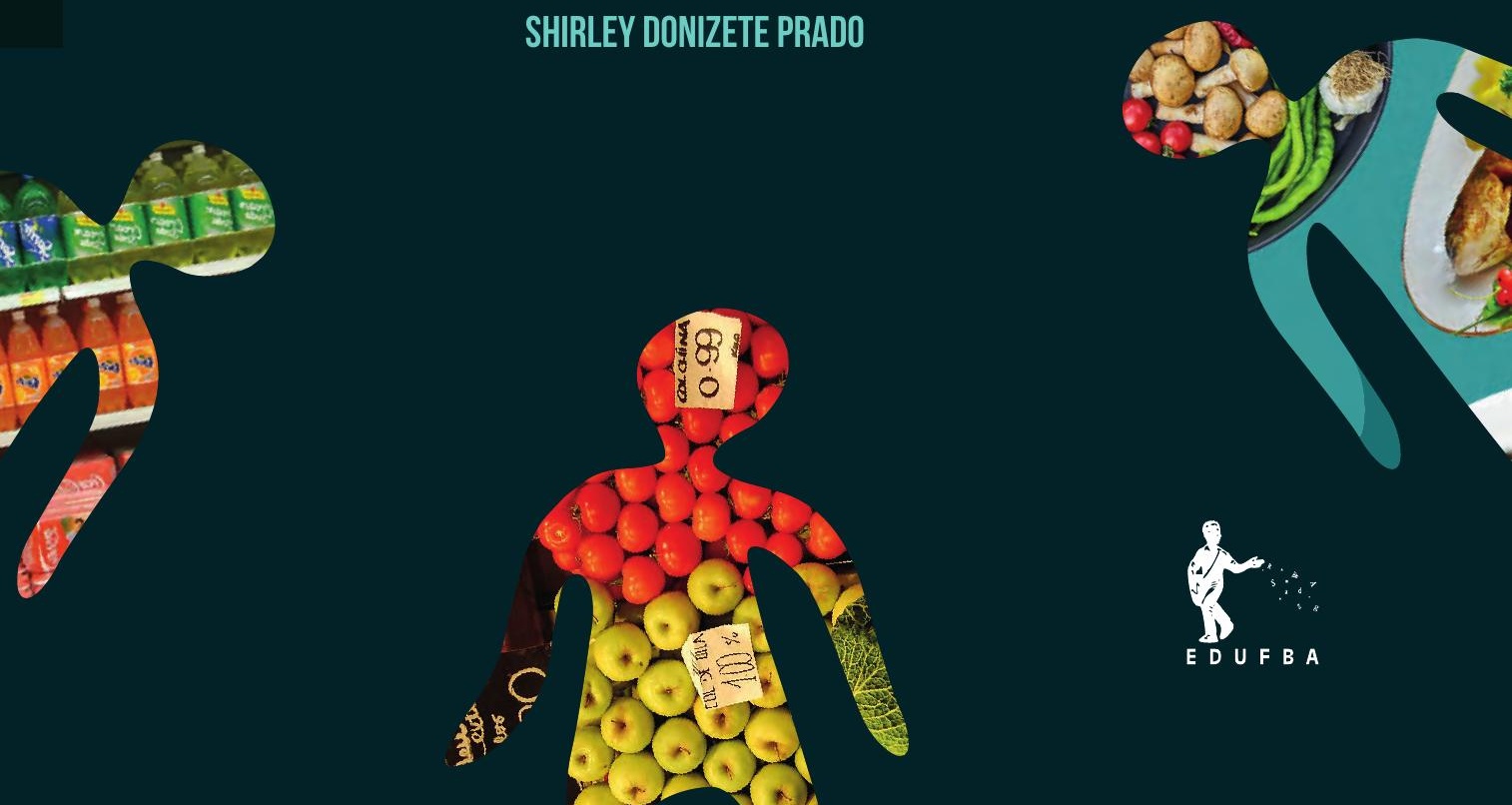


\section{COMENSALIDADES em Trangito}




\section{UNIVERSIDADE FEDERAL DA BAHIA}

Reitor

João Carlos Salles Pires da Silva

Vice-reitor

Paulo Cesar Miguez de Oliveira

Assessor do Reitor

Paulo Costa Lima

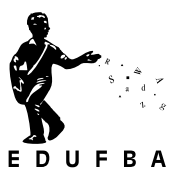

EDITORA DA UNIVERSIDADE FEDERAL DA BAHIA

Diretora

Flávia Goulart Mota Garcia Rosa

Conselho Editorial

Alberto Brum Novaes

Angelo Szaniecki Perret Serpa

Caiuby Alves da Costa

Charbel Niño El Hani

Cleise Furtado Mendes

Evelina de Carvalho Sá Hoisel

Maria do Carmo Soares de Freitas

Maria Vidal de Negreiros Camargo
(Série Sabor Metrópole, v. 11)

A Série Sabor Metrópole

é organizada por

NECTAR Núcleo de Estudos sobre Cultura e Alimentação Instituto de Nutrição Universidade do Estado do Rio de Janeiro

LACON Laboratório de Comunicação, Cidade e Consumo Faculdade de Comunicação Social Universidade do Estado do Rio de Janeiro

Esta coletânea foi organizada por

\section{REDE NAUS}

Rede Ibero-Americana de Pesquisa Qualitativa em Alimentação e Sociedade

Em parceria com

\section{LADIG'E}

Laboratório Digital de Educação Alimentar Instituto de Nutrição Josué de Castro Universidade do Federal do Rio de Janeiro Rio de Janeiro, Brasil

\section{NECTAR}

Núcleo de Estudos sobre Cultura e Alimentação Instituto de Nutrição Universidade do Estado do Rio de Janeiro Rio de Janeiro, Brasil

Apoio: 


\section{COMENSALIDADES

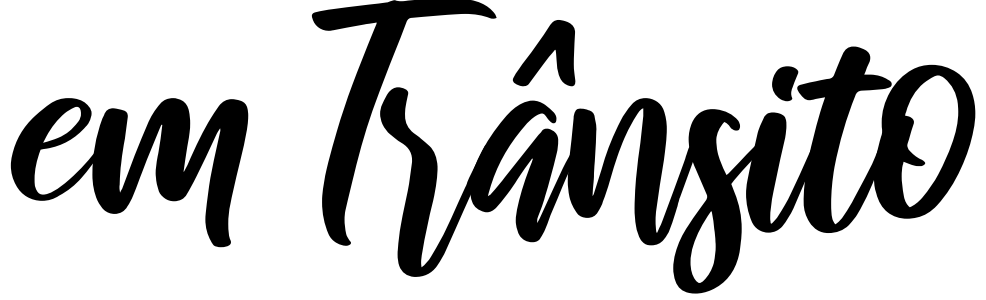

ORGANIZADORES

MARIA CLAUDIA DA VEIGA SOARES DE CARVALHO

FABIANA BOM KRAEMER

FRANCISCO ROMÃO FERREIRA

SHIRLEY DONIZETE PRADO

Salvador

Edufba

2020 
Autores, 2020.

Direitos para esta edição cedidos à Edufba.

Feito o Depósito Legal.

Grafia atualizada conforme o Acordo Ortográfico da Língua Portuguesa de 1990, em vigor no Brasil desde 2009.

Capa Gustavo Bastos Monteiro

Projeto gráfico e editoração Gabriel Cayres

Revisão Equipe da Edufba

Normalização Marcely Moreira

SISTEMA UNIVERSITÁRIO DE BIBLIOTECAS - UFBA

Comensalidades em trânsito / Maria Claudia da Veiga Soares de Carvalho... et al.(organizadores) Salvador: EDUFBA, 2020.

307 p.

ISBN: 978-65-5630-031-3

1. Nutrição. 2. Alimentos - Consumo. 3. Hábitos alimentares. I. Carvalho, Maria Claudia da Veiga Soaes de.

CDD - 613.2

Elaborada por Fernanda Xavier Guimarães: CRB-5/1675

Editora afiliada à

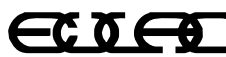

ASOCIACION DE EDITORIALE UNIVERSITARIAS DE AMERICA ATINA Y EL CARIBE

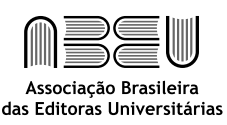

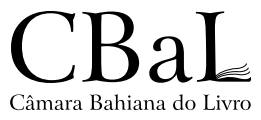

Editora da UFBA

Rua Barão de Jeremoabo

$\mathrm{s} / \mathrm{n}$ - Campus de Ondina

40170-115 - Salvador - Bahia

Tel.: +55 $713283-6164$ 


\section{AGRADECIMENTOS}

Registramos nossos agradecimentos ao Conselho Nacional de Desenvolvimento Científico e Tecnológico (CNPq), à Coordenação de Aperfeiçoamento de Pessoal de Pessoal de Ensino Superior (Capes), à Fundação de Amparo à Pesquisa do Estado do Rio de Janeiro (FAPERJ), à Universidade Federal do Rio de Janeiro, ao Instituto Oswaldo Cruz da Fundação Oswaldo Cruz e à Universidade do Estado do Rio de Janeiro (UERJ), pelo apoio financeiro nas modalidades auxílio e bolsa aos projetos "Consumo alimentar como problema complexo: reflexões conceituais" e "Educação alimentar em equipamentos sociais urbanos de alimentação e segurança alimentar e nutricional", o que viabilizou parcela relevante da produção desta obra. 



\section{Sumário}

11

O consumo alimentar como modo de perceber no mundo Maria Claudia da Veiga Soares Carvalho, Fabiana Bom Kraemer, Francisco Romão Ferreira e Shirley Donizete Prado

\section{PARTE I - CULTURA E CONSUMO ALIMENTAR}

17

Mote, llamas y piedras ausentes: etnografía de una kalapurca cuseña Laura Pey e Jesica Carreras

41

Dinâmicas culturais na alimentação: da formação das cozinhas à construção das identidades nacionais de Brasil e Portugal Talita Prado Barbosa Roim

67

Discursos sobre o comer de um grupo de trabalhadores: códigos de identificação do saudável nas práticas de alimentação Nathália César Nunes, Fabiana Bom Kraemer, Shirley Donizete Prado e Maria Cláudia Veiga Soares de Carvalho

\section{5}

Breves considerações sobre gastropolítica

Ewerton Reubens Coelho-Costa

\section{5}

"Cultura alimentar local" e reflexões sobre o "lugar": múltiplos sentidos em transformação Carolina Daltoé da Cunha, Shirley Donizete Prado, Fabiana Bom Kraemer e Luciane da Costa Moás 
Lactancia materna, red de apoyo y la penalización de la pobreza: reflexiones etnográficas sobre una opresión de género y clase Ana Gretel Echazú Böschemeier e Lucrecia Raquel Greco

\section{PARTE II - CÓDIGOS IDENTITÁRIOS E ALIMENTAÇÃO}

\section{5}

Identidades deslocadas em territórios estrangeiros: a comensalidade no filme Persépolis Silvana Silveira Campos, Francisco Romão Ferreira, Cristiane Marques Seixas e Eliane Portes Vargas

\section{7}

"Eu sou um petisco carioca!": correlações entre o biscoito Globo, a identidade e o imaginário do Rio de Janeiro Alessandra de Figueredo Porto e Cíntia Sanmartin Fernandes

\section{3}

Alimentação, direitos humanos e fluxos migratórios Caroline Filla Rosaneli, Anna Silvia Penteado Setti da Rocha, Tatyana Scheila Friedrich e Rodrigo Alvarenga

\section{5}

Vivências na interface dos campos da alimentação e educação Carolina Muniz Pessanha D’Almeida de Brito, Letícia da Silva Coutinho, Maria Cláudia da Veiga Soares Carvalho e Verônica Oliveira Figueiredo

\section{5}

Caridade para os merecedores e salvação para os doadores: sentidos da comida distribuída para a população em situação de rua Julia Horta Nasser, Shirley Donizete Prado, Francisco Romão Ferreira e Daniela Menezes Neiva Barcellos 
Discursos sobre alimentação saudável na Educação Básica: dissonâncias ou alternativas de educação alimentar? Vanessa Nascimento Moreira, Maria Cláudia da Veiga Soares Carvalho, Eliane Portes Vargas e Flávia Milagres Campos 



\section{O CONSUMO ALIMENTAR COMO MODO DE PERCEBER NO MUNDO}

Temos o prazer de apresentar esta coletânea que resulta de parceria entre o Laboratório Digital de Educação Alimentar (LADIG’E) do Instituto de Nutrição Josué de Castro da Universidade do Federal do Rio de Janeiro (UFRJ) e o Núcleo de Estudos sobre Cultura e Alimentação (NECTAR) do Instituto de Nutrição da Universidade do Estado do Rio de Janeiro (UERJ).

Corresponde à quarta iniciativa da Rede Ibero-Americana de Pesquisa Qualitativa em Alimentação e Sociedade (REDE NAUS) em matéria de publicações e que, assim, se consolida como uma via através da qual fluem conhecimentos, construindo cooperação acadêmica e firmando a liberdade para criação humana como referência central.

Para chegarmos a esta obra, partimos de uma chamada dirigida aos estudiosos ibero-americanos, à qual obtivemos resposta numericamente muito expressiva e de elevada qualidade analítica. Selecionar os textos que ao final seriam publicados exigiu de nós avaliação bastante criteriosa e de alto refinamento orientada por referenciais centrados no eixo temático teórico e metodológico que definiu o movimento de construção desta linha de debates.

Assim, este encontro de pesquisadores reúne estudos sobre comida, identidades sociais e subjetividades. Um conjunto que consolida esse modo de produzir e divulgar conhecimentos e saberes e que reafirma uma 
liberdade para orientar novas metodologias para novos objetos de análise no campo das Ciências Humanas e Sociais em Alimentação.

Nessa coletânea voltamos nosso olhar para o caráter transitório dos códigos identitários que vamos assumindo em função de determinados consumos. Consumir uma comida ou outra, em grupo ou sozinho, postando nas redes sociais ou não é parte de um modo inerente ao espírito humano de afirmar, e também de negar, identidades. $\mathrm{O}$ consumo na sociedade contemporânea marca um processo que organiza o modo como percebemos o mundo. Se há um fluxo de significação de alimentos como frutas, legumes e verduras como ícones modernos de alimentação saudável, será essa a condição transitória de significação que nos fará sentir mais ou menos saudáveis. A experiência do comer e da comensalidade é inerente ao momento presente no qual os objetos materiais e simbólicos são depositários de narrativas e memórias que flutuam na cultura em aromas, formas, gestos e emoções.

O que nos cabe na organização desta coletânea é favorecer e valorizar espaços para o debate como uma ponte transitória que nos conduz, em meio a essas significações contemporâneas, à construção de identidades singulares imbricadas numa modernidade capitalista e industrial. Nosso objetivo é apresentar análises neste contexto de negociação e trocas simbólicas entre agentes sociais presentes nos campos de pesquisa, oferecendo ao leitor um cardápio de alternativas que desdobram identidades e inventam novos sentidos para a comensalidade contemporânea em diferentes contextos sociais.

A conexão com teorias das Ciências Humanas e Sociais abre novas abordagens críticas e de cunho qualitativo sobre objetos de pesquisa do campo da Saúde. Priorizamos os recursos teóricos que desnaturalizam verdades, desafiando-nos a enfrentar discursos hierarquizados e submissos, e também analisar a pluralidade e criatividade de outros no processo de fluxos transitórios. São criticadas afirmações de identidade como uma essência humana, assim como também a premissa moderna de uma 'autonomia individual' nas escolhas alimentares. $\mathrm{O}$ modo como nós nos percebemos como sujeito desdobra-se em uma existência transitória e plural de um fluxo de acontecimentos. A concepção de identidade não se assemelha ao DNA. Os códigos identitários são efeito de conjunções discursivas que operam uma miríade de significados do universo simbólico de uma cultura ou coletividade. Através da linguagem, os discursos ligam nossa intimidade mais sensível e 
singular, mas em formas transitórias que vão dando sentido de pertencimento às nossas vidas em cada momento.

Assim, dividimos os capítulos em dois momentos segundo a orientação temática: "Cultura e consumo alimentar" com seis capítulos e "Códigos identitários e alimentação" com outros seis. São analisados padrões de comida de verdade e de alimentação saudáveis em práticas discursivas situadas em espaços diversos, desde cozinhas até textos de livros escolares. Alguns estudos identificam o modo como padrões de vida saudável silenciam vozes e produzem violência simbólica. Os textos que selecionamos para leitura buscam refletir alternativas de pertencimento a um tipo de sociedade mais solidária que queremos e precisamos construir.

Maria Claudia da Veiga Soares Carvalho Fabiana Bom Kraemer Francisco Romão Ferreira Shirley Donizete Prado 

Partel 



\section{MOTE, LLAMAS Y PIEDRAS AUSENTES ETNOGRAFÍA DE UNA KALAPURCA CUSEÑA}

LAURA PEY

JESICA CARRERAS

\section{INTRODUCCIÓN A LA PROBLEMÁTICA (O EL POR QUÉ DE ESTA ETNOGRAFIA)}

La kalapurca es un plato tradicional andino muy antiguo que se prepara y consume en el norte de Chile, el sur de Bolivia y noroeste argentino. De origen aymara, su nombre deriva de las palabras qala (piedra) y phurk'a (acción de asar). (CERRÓN-PALOMINO, 2006) Esto se debe a que, en la mayoría de los casos, para su cocción se emplean piedras calientes. Sin embargo, existen tantas formas de denominarlo (calapurca, carapulca, calapulcra, pari rucru, entre otras) ${ }^{1}$ como ingredientes que pueda llevar su receta. Algunas kalapurcas tienen más ingredientes (pueden llevar carne, papa, mote, ${ }^{2}$ cebolla, yerba buena), otras menos. Las carnes que se utilizan varían de una región a otra, pudiendo ser de llama, alpaca, pollo, cordero; todas ellas desmenuzadas. Debido a la cantidad de ingredientes alóctonos

1 En este capítulo optamos por llamarlo "kalapurca”, al igual que lo hacen en Cusi Cusi.

2 La palabra mote viene del quechua mut'i y es el nombre genérico que se le otorga a distintos granos o legumbres (maíz, trigo etc.) hervidos durante muchas horas. 
que se le han incorporado, la antropóloga Sonia Montecino (2004) considera que, en la actualidad, se trata de un plato "mestizo" donde se combinan lo ancestral, lo colonial y lo actual. Pero según la autora, hay un elemento fundamental para la cocción que no varía y éstas son las piedras calientes. (MONTECINO, 2003; 2004; 2007)

Ahora bien, ¿cómo fue nuestra primera aproximación al plato y por qué decidimos escribir sobre él? Ambas autoras formamos parte de un equipo de investigación interdisciplinaria ${ }^{3}$ que trabaja hace más de una década en la microrregión de Cusi Cusi (Puna de Jujuy, Argentina). Uno de los objetivos actuales del equipo es relevar las lógicas y narrativas que operan en la construcción del pasado por parte de la gente contemporánea; y cómo éstas se activan al habitar el paisaje local. A la par, desde una mirada arqueológica, algunos/as investigamos cómo se habitó y construyó el paisaje a través del tiempo contemplando diferentes ejes temáticos y escalas temporales, teniendo en cuenta que Cusi Cusi es habitado desde, al menos, 8000 años AP. (VAQUER; CÁMERA, 2018) En particular, nosotras compartimos el interés por la producción y consumo local de alimentos que existen en la microrregión desde el Siglo XIII. Una estudia el consumo de restos faunísticos en contextos agropastoriles; la otra investiga la producción de alimentos desde el punto de vista agrícola. En definitiva, a ambas nos une un interés conjunto: la cocina y la comida andina.

Desde hace varios años nuestros/as compañeros/as de equipo realizan entrevistas etnográficas en búsqueda de las historias e interpretaciones locales sobre el paisaje y el pasado. (VAQUER; PETIT DE MURAT; DI TULLIO, 2018) En la mayoría de las visitas a las casas del pueblo, muchas de las mujeres niegan saber cosa alguna sobre el pasado, dicen no recordar, dejan que su marido cuente. El 3 de mayo de 2017, estuvimos invitados/as a participar en los festejos del aniversario del pueblo y fue allí cuando probamos por primera vez la kalapurca cuseña. Ésta fue cocinada por un grupo de mujeres del pueblo y presentada como el plato típico tradicional local, una receta ancestral que se prepara en épocas festivas como el aniversario

3 Proyecto Arqueológico y Antropológico Pallqa dirigido por el Dr. José María Vaquer. En la actualidad, nuestras investigaciones se enmarcan en el proyecto 'Paisaje, memoria y territorio en Cusi Cusi (Rinconada, Jujuy): hacia un diálogo interepistémico', FiloCyT FC19-068. 
del pueblo y la Señalada. ${ }^{4}$ Ese plato, entonces, tenía historia, y esa historia estaba en manos de ellas. Fue así como nos decidimos a volver cada 3 de mayo a compartir y participar de la experiencia, un intercambio de saberes que condensa los dos ejes que nos interesan, la cocina andina y el pasado.

Tras dos primeras experiencias (CARRERAS; PEY, 2019), hemos entendido a la kalapurca cuseña como un plato nativo condensador de historias familiares, de distintas trayectorias y distintos paisajes. Una comida que lleva cebolla, mote de maíz, caldo de llama, puré de tomates, orégano y sal, y cuyo ingrediente principal es la carne de llama local desmenuzada. Hemos comprendido que la carne de llama se comporta, en términos de Weismantel (1994) como un validator, es decir, un ingrediente indispensable e irremplazable, a diferencia de los demás. Se trata de un ingrediente clave que hace directamente al entramado pastoril cuseño y remite a la identidad del pueblo que siempre busca reforzarse en los eventos locales.

A su vez, cocinando con las cuseñas no solo hemos aprendido que este plato data de, al menos, la época fundacional del pueblo, sino también que antes el protagonismo de las piedras en su preparación era mayor: en forma de pecana y kutana rumis $^{5}$ para procesar sus ingredientes, y en forma de esas piedras redonditas y lisitas que antes le echaban a la olla. Hoy en día, éstas últimas ya no forman parte de la receta local. Teniendo en cuenta los requisitos antes mencionados, para que una kalapurca sea considerada como tal, decidimos llamar a estas piedras el "ingrediente ausente”. (CARRERAS; PEY, 2019) Sin embargo, hemos observado que aún perviven en lo nominal (qala-phurk'a) y en el recuerdo, en todas las historias que nos han narrado al respecto. Y no solo nos han contado muchas historias, sino que gesto a gesto, nos han narrado las diferentes formas que existen y han existido de cocinar este plato. Cada 3 de mayo, las mujeres cuseñas nos recuerdan que el pasado no siempre se narra con la palabra, sino también con el cuerpo. El pasado se cuenta haciendo la kalapurca.

Tras una tercera experiencia etnográfica, y entendiendo a la cocina como una práctica más de memoria social, en esta oportunidad nos proponemos

4 Uno de los eventos más importantes del calendario ritual-productivo pastoril, llevado a cabo en la estación húmeda y en el que los animales de la hacienda son marcados siendo así incorporados a la familia del/a pastor/a.

5 Instrumentos líticos de molienda. 
continuar documentando las prácticas culinarias en torno a este plato en Cusi Cusi. Nos interesa seguir explorando la kalapurca cuseña como condensadora de sentidos, temporalidades e historias centrándonos en los gestos y sabores involucrados en su preparación.

\section{SER EN EL MUNDO Y CORPORALIDAD}

Habitar el mundo implica dos instancias interpretativas: una corporal (pre discursiva) y una narrativa (discursiva). Esto se debe a que el ser humano no existe como forma pura y aislada, sino que desde el primer momento en que intenta comprenderse y autodeterminarse ya se encuentra en relación. (HEIDEGGER, 2009) Es decir, el mundo está ahí previamente a cualquier análisis que podamos hacer del mismo. Nuestra forma de habitar es situada y a esto se refiere Heidegger cuando habla de Dasein (ser o estar aquí). Para el ser humano no existe otra forma de ser que no sea ser-en-el-mundo.

En sintonía, Merleau-Ponty (1993) nos invita a entender que la forma que tenemos de situarnos en este mundo es siempre corporal. El cuerpo es quien media todas las relaciones con el mundo, y llegamos a conocerlo mediante la percepción. Por ello, la corporalidad es el elemento constitutivo de los sujetos. Desde una perspectiva fenomenológica, el filósofo propone un abordaje dialéctico de la corporalidad. Éste consiste en comprender y describir la experiencia práctica del cuerpo en la vida social. Es dicer, la materialidad del cuerpo y su capacidad pre-reflexiva de relación con el mundo a través de percepciones, sensaciones, gestos y movimientos construidos socialmente, pero también, socialmente constituyentes (allí radica el carácter dialéctico). En este trabajo nos interesa recuperar este abordaje, esta mirada, reparando particularmente en aquellos movimientos y gestos construidos socialmente.

\section{TÉCNICAS CORPORALES Y GESTOS EN EL COCINAR}

Aquí proponemos al/la lector/a comprender el cocinar como un conjunto de técnicas y, en algunos procesos particulares, como un conjunto de técnicas corporales. Una técnica puede definirse como "todo acto eficaz tradicional”. (MAUSS, 1979, p. 342) Según Mauss (1979), a pesar del uso de herramientas, nuestro medio técnico más común es el cuerpo. En este sentido, una técnica corporal es la forma en la que los hombres y mujeres 
hacemos uso de nuestro cuerpo en las distintas sociedades. Nuestra forma de movernos nunca es natural, sino que es adquirida mediante el aprendizaje y la imitación a lo largo de la vida. Cada técnica tiene su forma y el gesto manual se aprende lentamente. (MAUSS, 1979) Generalmente, usamos como referentes a personas que poseen mayor experiencia y/o autoridad en la ejecución de la técnica que aprenderemos. Por lo tanto, el aprendizaje de la técnica es social.

Centrándonos en los gestos específicos que componen a las técnicas, para André Haudricourt (2010), un gesto implica un cuerpo que ejerce un movimiento; muchas veces con relación a un objeto, con una determinada fuerza y en un determinado contexto. Esto último es muy importante ya que el gesto carece de sentido si no es en relación con un medio ambiente, una situación dada y un contexto social específico. En este caso, pensaremos en las relaciones entre materias primas (que luego serán ingredientes), utensilios y cocineras. Decimos cocineras ya que, en la cocina andina (como en muchas otras) las mujeres son las verdaderas agentes de las técnicas desde pequeñas. (PAZZARELLI, 2010) Entonces, el cocinar está compuesto por una serie de técnicas y éstas implican la replicación de gestos muy específicos.

En el caso del empleo de utensilios y elementos propios de la cocina, debemos tener en cuenta que la herramienta permanece inseparable del gesto que la hace técnicamente eficaz. (LEROI-GOURHAN, 1989) De hecho, en la cocina, cada implemento implica un gesto (no se bate igual con un tenedor que con un batidor manual y ini hablar de una batidora eléctrica!). Pero, aunque el gesto implique la manipulación de un objeto (por ejemplo, picar una cebolla con un cuchillo pequeño), o se realice simplemente con las manos (por ejemplo, amasar la harina del pan), "requiere toda una movilización del cuerpo que se balancea en una cadencia al ritmo de los esfuerzos sucesivos exigidos por la tarea que se va a ejecutar". (GIARD, 1999, p. 208)

Las técnicas son elecciones culturales fuertemente vinculadas con las representaciones sobre el mundo que posee cada sociedad. Por esto no resulta extraño que muchos de los gestos empleados en la cocina se repitan en diferentes esferas de actividades de la vida cotidiana. Sillar (1996) menciona algunos casos andinos en donde se replican técnicas asociadas al tratamiento del alimento en otros contextos que, desde nuestra mirada 
occidental, no poseen relación. Por ejemplo, moler minerales para producir el antiplástico de la pasta cerámica con la misma técnica (y hasta los mismos instrumentos) que se emplea para moler granos para producir harina. ${ }^{6}$ A partir de estas recurrencias, el arqueólogo plantea entender a las técnicas como metáforas culturales que remiten a una misma red de sentidos. En específico, las transformaciones que deben atravesar ciertos elementos para ser consumidos -incorporados- se vinculan directamente con la forma de comprender y habitar el entorno por parte de una sociedad.

Otros autores, como Alberti (2012, p. 17-25), entienden a los actos técnicos más que como metáforas, como "equivalentes ontológicos" de procesos parecidos en otros dominios, considerando que es el proceso técnico en sí el que define las relaciones ontológicas y no a la inversa. En sintonía, en "Hacer mundos con gestos", la filósofa Bardet (2019) sugiere que un gesto, más que una forma corporal, es un modo de relación entre los elementos que lo componen. $\mathrm{Y}$ en este sentido, el cuerpo mismo puede pensarse como una serie de gestos, es decir, de relaciones que ayudan a construir y sostener el mundo que se habita. Esas relaciones se establecen con los elementos que nos rodean ya sean objetos, plantas, animales, humanos u otros seres. Los gestos, entonces, nos hablan de -sino es que ayudan a construir- la manera en la que se conciben estas relaciones. En esta línea, Pazzarelli (2010) repara en la importancia del hervido y el molido en la esfera culinaria andina, en particular, en el caso del preparado de la sopa. Según el autor, "con cada golpe del batán y con cada hervor de las ollas las mujeres se encontrarían produciendo sopas, pero también liberando e incorporando las energías necesarias para la continuidad de la vida, en todos sus sentidos". (PAZZARELLI, 2010, p. 176)

\section{CONTAR Y PERCIBIR HISTORIAS CON EL CUERPO}

Si las técnicas y los gestos se aprenden mediante la observación e imitación, por más innovaciones que involucremos en el proceso, es inevitable que la reproducción de éstas nos remita al momento del aprendizaje. Y la situación de aprendizaje está inmersa en un contexto, una temporalidad definida y a un/a

6 Tras consultar fuentes etnohistóricas y etnográficas, Sillar concluye en que el gesto de moler se asocia a una percepción andina particular sobre cómo se deben procesar los materiales antes de ser productivos. Deben molerse, aplastarse, para ser incorporados de manera funcional y simbólica a la sociedad ya sea en forma de harina o de arcilla. (SILLAR, 1996, p. 267) 
referente. Más allá de la actual existencia de una prolífica cantidad de cursos y libros de cocina, en el cocinar cotidiano aún sigue primando el aprendizaje directo y éste generalmente se da en el ámbito del hogar, de la familia. "Las recetas familiares” son más que una enumeración de pasos (aquí proponemos entenderlos como gestos) e ingredientes, son una forma de memoria; una cadena de recuerdos que viajan desde el/la más joven de sus transmisores/as hasta el momento casi mítico de gestación del plato en la historia. Al mismo tiempo, cada uno/a de sus cocineros/as va a marcar su impronta en el proceso.

En síntesis, cocinar es una práctica más de rememoración. Se recuerdan no solo los ingredientes y gestos aprendidos, sino también las historias, las personas involucradas, una genealogía familiar y, en casos como el de la kalapurca, los orígenes de un pueblo. Entonces, la comida y la forma en la que se la prepara están estrechamente ligadas a la identidad de una sociedad. De hecho, así como se recuerda al cocinar, también se puede olvidar. Si se olvidan las acciones, los gestos, aquellas recetas que los acompañan también desaparecen, es decir, se borra una parte de la memoria de aquella familia o pueblo. (GIARD, 1999, p. 210)

Pero no solo se recuerda al cocinar, sino también al comer. Desde la antropología de los sentidos, Le Breton (2007, p. 257) propone entender la comida como un "objeto sensorial total”. La experiencia de la comida queda envuelta o sintetizada en el concepto del sabor. El sabor, para el autor, no solo remite lo que se percibe desde el sentido del gusto. Por el contrario, el sabor de un plato es una experiencia corporal sinestésica que trasciende su composición química, incluyendo las temperaturas, texturas, sonidos, formas, aromas, colores y paisajes que intervienen en la obtención y preparación de cada uno de los alimentos que componen el plato. En este sentido, comer se vuelve un "acto sensorial total” (LE BRETON, 2007, p. 263) donde un sabor puede hacernos viajar mediante el recuerdo en el tiempo y el espacio. Al mismo tiempo, el comer es una recapitulación -y reactualización- del mundo sensorial específico en el que la sociedad vive y reproduce cotidianamente. (CÁRDENAS-CARRIÓN, 2014)

\section{ETNOGRAFÍA}

Uno de los pilares fundamentales del trabajo etnográfico es la observación participante. Esta instancia del trabajo de campo permite incorporarnos a 
actividades de la vida cotidiana de otras personas. Como afirma Pablo Wright (1994), el sujeto-etnógrafo desplaza su ser-en-el-mundo a un lugar diferente. Nos exige usar nuestros cuerpos como otros lo hacen. (CITRO, 1999) Es que el conocimiento etnográfico está fundamentado por esa participación personal (que involucra las percepciones de los sentidos), en la experiencia de campo. En esta línea, Silvia Citro (1999, p. 92) plantea el descentramiento del rol tradicional del etnógrafo/a, proponiendo que las dimensiones personales, afectivas y socioculturales del investigador/a se integren a las experiencias de campo. La estructura ontológica del etnógrafo/a es la que sufre modificaciones en su contacto con las personas. (WRIGHT, 1994, p. 366-367) Aquí, entendemos a la cocina y a la alimentación como un hecho social total. Consideramos, entonces, "que el acto [o hecho] social total sea total no solo significa que todo aquello que se observa forma parte de la observación, sino también y, sobre todo, que en una ciencia en que el observador es de la misma naturaleza que su objeto, éste es también parte integrante de su observación”. (LÉVI-STRAUSS, 1979, p. 25, traducción propia) Por eso, lo que les pasa a nuestros cuerpos de etnógrafas en este desplazamiento ontológico (WRIGHT, 1994), resulta central, ya que nos permite situar nuestro análisis y nuestras interpretaciones.

Por lo tanto, consideramos necesario situarnos a nosotras mismas. Además de ser arqueólogas, recibidas en la Universidad de Buenos Aires, somos mujeres. Y este no es un dato menor para esta etnografía particular. Ambas nos criamos en la provincia de Buenos Aires, y desde pequeñas nos enseñaron a cocinar. Aprendimos con tareas simples al principio, observando y colaborando en diversas prácticas culinarias. Alcanzar ingredientes a la persona que cocinaba, cortar verduras, servir y alcanzar la comida, levantar los platos de la mesa, lavar la vajilla utilizada, son tareas con las que nosotras estamos sumamente familiarizadas en nuestra vida cotidiana. Actualmente cocinamos en nuestras casas todos los días. Picamos, hervimos, salteamos, revolvemos, hidratamos, condimentamos, horneamos, asamos. Sin embargo, a la hora de observar y participar de las prácticas culinarias en las que intervienen las mujeres de Cusi Cusi, necesitamos desaprender lo que hemos aprendido (tanto conceptual como corporalmente). Porque, aunque nuestra forma de cocinar y la forma de cocinar de ellas pueden tener puntos de contacto, existen muchas prácticas en la cocina que son ajenas a las nuestras, movimientos, técnicas, instrumentos, utensilios, formas de 
cocción. En la práctica etnográfica nos vemos en la necesidad de olvidarnos de nuestras formas, de observar e imitar el gesto ajeno. En definitiva, nos vemos en la necesidad de reaprender a cocinar.

Además de la observación participante, hemos realizado entrevistas a diferentes mujeres de la comunidad de Cusi Cusi. En el campo, desde lo discursivo, hemos dejado de referirnos a ellas con el nombre de entrevistas, y utilizamos en su lugar la palabra "charla”. (CARRERAS; PEY, 2019) Estas charlas se basaron en la técnica de la entrevista abierta, es decir conversaciones que poseen una estructura y una dirección, con temas dirigidos de acuerdo a los intereses compartidos de las partes implicadas. La entrevista abierta es útil para reparar en lo pragmático, es decir, en cómo los sujetos "actúan y reconstruyen el sistema de representaciones sociales en sus prácticas individuales”. (ALONSO, 2003, p. 71)

\section{CUSI CUSI}

En arqueología nos referimos al trabajo de campo con el término campaña. Las campañas requieren de mucha planificación previa. Se planifican las fechas, los objetivos, la comida que llevaremos, si iremos con vehículo propio o nos movilizaremos hasta el lugar en servicio de transporte de pasajeros. Planificamos todo lo que podemos planificar. Pero claro, por más que una planee minuciosamente, el solo hecho de llegar al campo implica un entramado de varias situaciones inciertas.

Cusi Cusi es un pueblo que se ubica en la puna de la provincia de Jujuy, cerca del límite geográfico actual entre Argentina y Bolivia. Se encuentra a gran altura, por encima de los 3800 metros sobre el nivel del mar, con un clima de escasas lluvias, y gran amplitud térmica. En el pueblo viven aproximadamente 243 personas. Podríamos decir muchas cosas sobre el pueblo, pero elegiremos algunas que nos resultan necesarias para situar este trabajo.

Para eso, empecemos por contextualizar nuestra llegada. En todo el pueblo hay un solo teléfono, ubicado en el edificio municipal, que es atendido por una persona cuyo trabajo consiste en cronometrar y cobrar el tiempo de uso y en caso de que ingrese una llamada, buscar al/la destinatario/a por el pueblo y avisarle. No hay señal de celular. Recién en el año 2015 comenzó a funcionar un "ciber" con internet en el Centro Integrador Comunitario (C.I.C.), y en mayo de 2019, wifi en la plaza central del pueblo. En este 
contexto, avisarle a la comunidad de nuestra llegada resulta una tarea complicada e infructuosa. Una llega cuando llega.

En mayo de 2019, nos disponíamos a realizar una nueva campaña etnográfica, en el marco del aniversario del pueblo. Ese año, el equipo de trabajo éramos solo nosotras dos. En Tilcara (Quebrada de Humahuaca, Jujuy) nos enteramos que el 1 de mayo, además de ser feriado internacional por el día del trabajador, no iban a salir ómnibus durante todo el día debido al acatamiento de un paro convocado por organismos que nuclean a los trabajadores del transporte. Ahí empezó lo que nosotras denominamos coloquialmente "surfear la incertidumbre".

Una de las formas de llegar a Cusi Cusi, la que nosotras solemos utilizar con más frecuencia cuando no contamos con el vehículo del equipo, consiste en tomarse un ómnibus que sale desde Abra Pampa, ciudad cabecera de la puna jujeña. Este ómnibus pertenece a quien generalmente es su chofer, don Burgos, y sale hacia Cusi Cusi, con paradas intermedias en algunos pueblos como Santo Domingo, Liviara y Loma Blanca los días lunes, miércoles y viernes a la mañana. Una vez que llega a Cusi Cusi, vuelve hacia Abra Pampa. El 1 de mayo de 2019 fue miércoles. Además de la incertidumbre del horario, no sabíamos si el Burgos saldría o no. Si se adhería al paro, resultaría imposible llegar al pueblo para el aniversario, ya que podríamos llegar recién el viernes 3 , pasado el mediodía. Desde Tilcara nadie sabía indicarnos una forma de comunicarnos con la terminal de Abra Pampa para averiguar. Trabajo detectivesco de por medio, logramos dar con el número del teléfono celular de don Burgos, que ante la pregunta de si salía al día siguiente, nos respondió que sí. ¿Aún con el paro de transporte? Ya le dije que sí, señorita. El 1 de mayo, a las nueve de la mañana, de manera muy puntual, el Burgos salió rumbo a Cusi Cusi.

La incertidumbre continúa cuando una llega al pueblo, alrededor de las dos de la tarde, pleno horario de siesta, muy común en el norte de nuestro país. Generalmente, a partir de la una del mediodía, hasta pasadas las cinco de la tarde, la gente suele encontrarse en sus hogares, las calles están vacías, y localizar a alguien que nos brinde información se vuelve una tarea por demás compleja. Siempre que llegamos, no sabemos dónde dormiremos, cuándo se desarrollarán las actividades o si las autoridades son las mismas que el año anterior. A esa hora, solo queda esperar a que el pueblo se despierte, y las actividades afuera de las casas se reanuden. Y siempre 
(gracias a la hospitalidad de las autoridades y comunarios/as) no importa la cantidad de eventos inciertos que hayamos tenido que atravesar, la tarde de nuestra llegada contamos con un lugar donde dormir. Las planificaciones empiezan a readaptarse a los nuevos eventos, de la misma forma que nuestros cuerpos tienen que empezar a acostumbrarse a la altura. Nuestras categorías, de repente, se ven interpeladas por las cuseñas, donde el tiempo y su manejo es distinto al nuestro.

Cusi Cusi tiene como actividad económica tradicional el pastoreo, que consiste en la cría de ganado de ovinos y mayormente camélidos. Las llamas abundan en el campo, y hasta en el mismo pueblo, donde de vez en cuando puede verse a alguna paseando despistada. El pastoreo implica que los pastores y pastoras se muevan mucho en el paisaje. Cada familia suele tener más de una casa en diferentes puntos altitudinales, además del domicilio en el pueblo. Esto está relacionado con que los animales necesitan moverse en función de las pasturas disponibles, y los pastores y pastoras se mueven con ellos. Otras de las fuentes laborales que tienen mayor representatividad en el pueblo son la minería, el sector público y de servicios y la elaboración de tejidos por parte de mujeres (a nivel familiar). También existe la Cooperativa Agroganadera Cuenca Río Grande San Juan Limitada, destinada a la ganadería y la Cooperativa Agrícola de Comunidades Altoandinas Limitada o CADECAL, focalizada en la producción de quinua.

\section{COCINAR EN CUSI CUSI}

En esta línea, el concepto de "hacer la comida", específicamente "hacer la kalapurca” tiene significados diferentes para las cocineras de Cusi Cusi y para nosotras. Durante la kalapurqueada del año 2018, ya habíamos tenido el primer acercamiento a esta diferencia. (CARRERAS; PEY, 2019) Ese año las encargadas de realizar la kalapurca eran Balbina y su madre, doña Claudia (una mujer de unos 50 a 60 años). Días previos al evento fuimos varias veces a charlar con ellas, haciéndoles preguntas sobre esta comida, e indicando nuestra intención de ver cómo la hacían. Doña Claudia, ante la pregunta de cuándo se hacía la kalapurca, nos indicó que el mismo día que se servía. Pero otras mujeres, durante entrevistas que habíamos realizado antes, nos habían dicho que la carne y el mote, ingredientes básicos y constitutivos de la kalapurca, se cocinaban el día anterior. 
Empezamos a dudar. A dudar de nuestra capacidad de hacernos entender (queríamos ver cómo lo hacían), de la fidelidad de nuestra informante (¿sabría doña Claudia verdaderamente cuándo se hacían las cosas?), de las buenas intenciones de nuestra informante (¿no sería que doña Claudia no quería que nosotras veamos cómo se hacía?) y del entendimiento conceptual (¿no sería que 'hacer' la kalapurca era distinto para doña Claudia que para nosotras?). Porque la receta que todas nos relataban incluía pasos previos, como cocinar el maíz o hervir la carne. (CARRERAS; PEY, 2019, p. 48)

Porque para nosotras, cocinar implica seguir una receta, constituida por una serie de pasos necesarios, algunos simultáneos, otros que no permiten la superposición. Durante la kalapurqueada del año 2019, empezamos a entender que estábamos imponiendo nuestras categorías de cuándo se empezaba a cocinar el plato. ¿Por qué queríamos ver cuando se hervía el mote, y no cuando se cosechaba el maíz?

Algunas de las mujeres del pueblo nos habían dicho que la encargada de la kalapurqueada de ese año sería Candelaria, la mujer del comunero. ${ }^{7}$ Cuando nos acercamos hasta su casa para consultarle si podíamos aprender a cocinar y ayudarlas en la preparación, nos indicó que la kalapurca se hacía el día que se servía. Teniendo en cuenta nuestra experiencia del año anterior, preguntamos cuándo hervían el mote y cuándo tizaban la carne, ya que nunca lo habíamos podido ver. La noche anterior, fue la respuesta. Ahí entendimos que "hacer la kalapurca" remite al momento en que todos los ingredientes (la carne de llama deshilachada, el mote, la cebolla salteada) se unen en una gran olla a través del caldo. Aunque al mote tuvieron que hervirlo antes, al igual que la carne de llama, "el hacer" remitía a esa olla y a ese caldo, condensadores de la esencia del plato de kalapurca.

\section{HACER LA KALAPURCA}

La kalapurca este año se hizo en el marco de la $77^{\circ}$ fiesta patronal en honor a la Santa Cruz del Señor del Milagro y del $39^{\circ}$ Aniversario de la comisión municipal. El programa incluía diversas actividades, a desarrollarse durante

7 Autoridad principal de la Comunidad Aborigen. La Comunidad Aborigen de Cusi Cusi se denomina Orqho Runas, que en quechua significa 'la gente del cerro’. 
varios días, desde campeonatos de fútbol femenino, izamiento de la bandera nacional a cargo de diferentes entidades de importancia en el pueblo, rezo de la novena y luminaria a cargo de la Iglesia Católica, cuarteada, bandas de sikuris. Todo programado con horarios estipulados. El plato fuerte del evento sucedería el sábado 4 de mayo, con la llegada del Gobernador de la Provincia de Jujuy y la inauguración de una piedra basal para montar (en otro momento, claro) una antena $4 \mathrm{~g}$ para celulares. Para la ocasión se invitó a lo que ellos denominan residentes, que son cuseños y cuseñas que hoy en día viven en otras partes del país, y también se recibió a visitantes provenientes de la localidad de Soniquera en Bolivia, con los que los cuseños suelen mantener relaciones de reciprocidad.

En este contexto, durante tres días seguidos, un grupo de mujeres se dedicó a cocinar para dar de comer a la gente que organizaba las actividades, a los residentes que llegaron de visita, a los visitantes bolivianos, a las antropólogas y a todo aquel que se acercara al lugar. Cocinaron en el patio del Centro Cívico, que se comparte con el Club River Plate de Cusi Cusi. Se trata de un patio interno, rodeado de varias habitaciones cuyas puertas tienen salida a él. En el centro, habían construido con ladrillos grises huecos una estructura sobreelevada, donde se colocaron las ollas. Debajo, el fuego, generado a partir de la combustión de un arbusto típico de la zona, denominado tola. ${ }^{8}$ En una de las habitaciones se encontraban 12 llamas trozadas, $\mathrm{y}$ otros tantos corderos, que fueron comprados por la comunidad aborigen para el evento. También había bolsones de verdura, cajas y botellas de vino tinto, paquetes de fideos y de arroz, salsa de tomate, condimentos y otros ingredientes que serían utilizados durante toda la jornada. El humo, de a ráfagas, invadía el patio y hacía llorar los ojos de aquellos/as que nos encontrábamos cerca.

El grupo de personas que una podía encontrar en ese patio era variado y dependía de la hora, no siempre estaban las mismas cocineras, no siempre había la misma cantidad de ollas en el fuego. Desde temprano a la mañana, hasta bien entrada la noche, había mujeres cocinando y hombres y niños entrando y saliendo de las habitaciones, en busca de objetos o

8 En la Puna de Jujuy se denomina tola a diversas especies vegetales de la familia Asteraceae o Compositae (géneros Parastrepiaq, Baccharis, Fabiana, entre otros). Son arbustos que forman matorrales o estepas características llamadas ‘tolares' y cuyo hábitat se ubica entre los 3.800 y 4.300 msnm. 
simplemente recibiendo un plato de comida. No sabemos con exactitud si en algún momento de la noche se retiraron, y ese patio quedó vacío. De día, las mesas, auxiliares de cocina y sustitutas de mesadas, eran corridas en busca de la sombra que otorgaban las paredes de las habitaciones circundantes. De noche, un potente reflector iluminaba la zona.

\section{TIZAR LA CARNE}

El viernes por la noche, Candelaria (que tiene entre 35 y 40 años) nos informó que al día siguiente iban a cocinar la kalapurca. Nos dijo que ellas (la mayoría mujeres de su generación) iban a empezar a las cinco de la mañana, porque había que preparar, además, el desayuno y el almuerzo para los visitantes, pero que nosotras podíamos llegar a las ocho. Con temor de volver a perdernos el momento en el que se desmenuza la carne, nos levantamos muy temprano.

En el preparado de la kalapurca, como señala Montecino (2004), el desmenuzamiento de la carne en hilos es el proceso clave de la preparación. Es la ejecución de determinadas técnicas lo que hace que la kalapurca sea kalapurca, y no sea otra comida. El gesto técnico de desmenuzar la carne, en Cusi Cusi es denominado "tizar". Esta es una palabra, y un gesto muy particular, que se asocia con el mundo del tejido. El tizado (también denominado "despelado") consiste en la limpieza de la lana tras el esquilado y es un paso previo al hilado. Se utilizan las manos para estirar la lana, extrayendo las durezas y motas, obteniendo como resultado una lana más fina lista para hilarse mediante el huso o pushka. En el caso de la carne, es necesario que ésta se haya hervido muchas horas para poder tizarse. El gesto en sí es muy preciso, como una suerte de "pellizco" continuo que permite separar la lana (o la carne) en pequeños y finos trozos. ${ }^{9}$ Tanto si se aplica a la carne o a la lana, el resultado se concibe como "hilitos", la kalapurca lleva "hilitos de carne" que previamente fueron tizados. Otro factor que comparten el universo del tejido con el de la kalapurca, a través del gesto del tizado, es la edad en la que se aprende a obtener estos hilitos. Las cuseñas nos han comentado que es una tarea que se le suele dar a los/as más jóvenes, a los/as niños. Es un gesto que, como la mayoría,

9 Ver: https://www.youtube.com/watch?v=BomJOTM_6Qg. 
se aprende por imitación y repetición. En este caso, repetición continua durante horas y horas de trabajo ya que ambas tareas - el tizado de lana y el tizado de la carne para la kalapurca - requieren mucho tiempo.

Aquel sábado por la mañana, apenas llegamos nos sirvieron el obligado (y necesario) mate cocido con bollo (pan), y una vez finalizado comenzamos a ayudar a cocinar. Candelaria, que sabía de nuestro interés en el tizado, nos había reservado dos vértebras con carne en una ollita, para que no nos perdamos la oportunidad de hacerlo. Aún era de noche, y el frío puneño de mayo se hacía sentir en las caras y en las manos. En una mesa al lado del fuego, tres mujeres, entre ellas Dominga (la mayor del grupo, de aproximadamente 50 años), arrancaban trozos de carne con sus manos de las vértebras hervidas de llama. Nos sumamos a la actividad, imitando sin conseguirlo, los movimientos de las otras cocineras. El frío no colaboraba con la motricidad fina que los dedos necesitan para realizar ese movimiento, al que nosotras no estamos acostumbradas. La carne extraída de la olla estaba aún tibia y servía, por un breve momento, para calentar las manos. Dominga tizaba a una velocidad sorprendente, imposible de seguir, y conseguía largos hilos de carne. Su técnica consistía en arrancar un pedazo de carne, arrojarlo a una olla, y después con movimientos rápidos y precisos de sus dedos, realizar el deshilachado. Nuestros platos se diferenciaban a simple vista de los de aquellas manos experimentadas. Eran pedacitos de carne cortados con dedos semi congelados, que en nada se asemejaban a esos hilos de carne estilizados de Dominga. Cada tanto, las tizadoras nos tocaban las manos y, al percibir el frío de nuestros dedos, nos indicaban que nos arrimemos al fuego, que así no podíamos tizar.

\section{MEZCLAR CON TODO EL CUERPO}

Mientras tanto, en una de las grandes ollas colocadas encima del fuego, se freía la cebolla que constituiría la base de la kalapurca. Dominga fue la encargada de realizar otra de las etapas clave en la preparación de este plato, el mezclado de la carne con el mote. El mote, ya hervido desde el día anterior, aguardaba reservado en una olla alta. Dominga arrojó la carne de todos nuestros platos en una tercera olla de metal, bajita y de boca ancha. Se puso en cuclillas, y con sus manos comenzó a mezclar. Un poco de carne, un poco de mote. Todo su cuerpo estaba involucrado 
en la tarea, sus rodillas flexionadas, sus piernas sosteniendo el peso de su cuerpo, los brazos haciendo fuerza mientras sus manos, cual cucharas gigantes, con movimientos envolventes integraban esos dos ingredientes tan distintos entre sí. Citando a Giard (1999, p. 155), "todo el cuerpo habitado por el ritmo del hacer".

Para realizar la mezcla, el conocimiento de las proporciones viene de la experiencia, las cantidades no son iguales ni parejas. En otra ocasión una cocinera nos dijo, tras sumar carne a la kalapurca: "sino van a pensar que aquí no hay llamas”. (CARRERAS; PEY, 2019) El resto de las tizadoras de carne seguimos con la tarea, porque la orden de Dominga fue que este ingrediente escaseaba. Cada nuevo plato de carne se incorporaba a la mezcla. Cuando ella consideró que había conseguido el balance necesario, lo agregó a la olla con la cebolla sofrita y, valiéndose de un cucharón de metal, revolvió mientras agregaba el caldo. La kalapurca, con su forma final, hervía a borbotones.

Cuando el sol de la mañana empezaba a iluminar el patio, Candelaria le pidió a Dominga que empezaran a servir la kalapurca. El momento en el que la condimentaron no lo vimos. La urgencia de lavar nuestras manos llenas de grasa, después de que las utilizamos como instrumentos de corte, hizo que nos lo perdiéramos. Las cocineras que hasta ese momento habían estado abocadas a la preparación de ese plato, ya habían comenzado a cortar cebollas, tomates y morrones para hacer la ensalada que, más entrado el mediodía, acompañaría el asado. La kalapurca se sirvió en platos de metal y con cuchara a todo aquel que se acercara.

\section{COCINA COLECTIVA}

Estar a cargo de cocinar durante los festejos por el aniversario implica, ante todo, tomar muchas de las decisiones. Cuándo hay que empezar a cocinar el estofado, si la cantidad de carne destinada al asado del almuerzo es suficiente, si ya es hora de empezar a hacer la kalapurca. Durante los tres días en los que se cocina desde temprano a la mañana hasta bien entrada la noche, hay horarios que cumplir. El reloj rige gran parte de las actividades culinarias, ya que darle de comer a tanta gente no es tarea sencilla. Pero el reloj no es solo un reloj físico. La percepción del tiempo se siente corporalmente durante esas largas jornadas de cocina. Se empieza cocinando bien temprano 
a la mañana, con un reflector como iluminación y con el frío de la noche que aún se siente en el cuerpo. Con el pasar de las horas, el sol no solo comienza a iluminar, sino que también aumenta considerablemente la temperatura. Ese sol que con sus primeros rayos nos hace a todos amontonarnos en su franja de calor, al mediodía empieza a calcinarnos y logra que nadie quiera quedar a su merced. Nos obliga, como ya hemos mencionado más arriba, a refugiarnos en los pocos lugares de sombra disponibles. Es que de eso se trata la amplitud térmica: calor durante el día, frío durante la noche. Porque, además, la comida es un marcador de tiempo. Divide y estructura el día. La kalapurca, por ejemplo, se come entre el desayuno y el almuerzo.

En este contexto, si bien Candelaria fue la encargada de la cocina ese año, el resto de las cocineras también tomaron decisiones. Fue, además, la encargada de repartir tareas. La kalapurca, por ejemplo, estuvo a cargo de Dominga. Sin embargo, el anchi de chicha, ${ }^{10}$ que nos había remarcado que también era tradicional de su cultura, lo realizó ella enteramente. Esto marcó un criterio de autoridad, dado que Candelaria era la única que sabía prepararlo. Era su especialidad.

Una de las mujeres estuvo siempre atenta al avivado del fuego, ya que debe permanecer prendido durante largas horas, y debe tener la potencia necesaria para hacer hervir el contenido de ollas con más de cien litros de capacidad. Para eso, en el patio había una gran cantidad de tolas cortadas y secas. El fuego permanece prendido durante toda la jornada de cocina. Es, muchas veces, el que marca el ritmo y el centro del espacio. No siempre hubo la misma cantidad de ollas, dependía del horario, las actividades planificadas, las comidas que debían cocinarse. Y esa variedad en el número de ollas se evidenciaba, a su vez, en los diferentes módulos sobre los que se apoyaban. Como ya hemos mencionado, se construyeron estructuras con ladrillos huecos grises, y a medida que se necesitaba más espacio de cocina, se colocaban otros, agrandando el espacio construido. Todas las comidas que se cocinaron a lo largo del evento se hicieron en este espacio. La kalapurca, el mote, el anchi de chicha, el estofado, el asado, la sopa. Todas preparadas en sus ollas y recipientes distintivos. La sopa, plato infaltable de cada

10 El anchi es un postre tradicional del noroeste argentino. Se prepara a base de sémola de maíz, azúcar y jugo de limón. En este caso, se trata de un anchi preparado a base de chicha, una bebida andina producto de la fermentación de algún grano como maíz o trigo. 
comida puneña, se hace en olla de barro que, al ser permeable y porosa, permite retener y condensar el sabor de la comida.

Algo que nos interesa remarcar a partir de nuestras observaciones en esta experiencia de cocina comunitaria es la relación con los utensilios de cocina. En el cocinar cotidiano, el de todos los días, cuando se cocina para los niños que vuelven del colegio, o en los puestos en el campo, cuando se prepara el almuerzo o la cena, los instrumentos que se utilizan son personales, son del ámbito de la casa. En cambio, cuando la cocina es comunitaria, cuando son muchas las manos que intervienen en las ollas, los utensilios pertenecen al grupo. Durante la kalapurqueada del año 2018, organizada por la comisión pro-templo de la iglesia católica, los platos, tazas, cucharas y ollas que se usaron fueron de la parroquia, y se marcan, con pintura esmaltada, las siglas correspondientes. Lo mismo sucede con los utensilios que pertenecen a la comisión municipal, o en el caso de la kalapurqueada del 2019, al Centro Cívico. Cada institución está equipada con platos hondos de metal (blancos, con algunas flores en colores), cucharas (todas las comidas se comen o bien con la mano o bien con cuchara), ollas (de metal, de todos los tamaños), una pava (generalmente grande y de metal), tazas plásticas, cucharones, algunas ollas de barro. Lo mismo sucede con los colchones. Todas las instituciones cuentan con varios que son utilizados en las numerosas ocasiones en que los cuseños reciben gente invitada.

En el Centro Cívico, en ese patio con corazón de fogón las cocineras se quejaban de que los cuchillos no cortaban. El rallador tampoco rallaba. Se encontraban gastados por el uso. Además, no había mesadas o lugares cómodos donde poder cortar, picar, trozar o tizar. Pero más allá de las quejas de las cocineras, y de cierta incomodidad, todo se resolvía a gran velocidad. Las improvisadas mesadas eran escritorios rotos de la escuela y algunos tablones sobre caballetes, la falta de tablas de cortar se resolvía cortando arriba de las mesas de madera. Ante la ausencia de suficientes cucharones, cuando las ollas eran muchas sobre el fuego, se usaban palos largos para revolver. Cuando la cantidad de cocineras superaba el número de cuchillos disponibles, o bien nos turnábamos en su uso o alguna iba a buscar un cuchillo extra a sus casas (que después se aseguraba de llevárselo consigo nuevamente). El tema del rallador maltrecho, lamentablemente, no tuvo solución. Se lo usó de todas formas, con sus filos desafilados y su asa rota. 


\section{SOBRE LOS GESTOS Y LAS TÉCNICAS DEL CUERPO}

Anteriormente planteamos que las técnicas pueden entenderse como metáforas culturales, es decir, son formas de corporizar la manera en la que se entiende y se construye el mundo dentro de una sociedad. (SILLAR, 1996) Esto explicaría el porqué muchas veces se retoman técnicas específicas de un área para aplicarse en contextos - y materiales - totalmente distintos. En el proceso de preparación de la kalapurca nos encontramos con una técnica particular - el tizado - que remite no solo en lo nominal sino también en lo gestual, a la esfera textil. Al respecto, podría señalarse que en Cusi Cusi la actividad textil se encuentra, generalmente, en manos de las mujeres del pueblo al igual que la cocina de la kalapurca. A su vez, y como mencionamos anteriormente, las técnicas involucradas se aprenden a temprana edad, sobre todo la técnica del tizado (ya sea de carne o de lana). Sin embargo, en un contexto andino, que se retome en la cocina un gesto del mundo del tejido no es extraño y posee una connotación particular.

En los Andes el tejido es una "actividad mágica y fundamental en la creación del mundo, en su nítida relación con la hilvanación de las palabras le acompañan”. (ARNOLD; YAPITA; APAZA, 1996, p. 411) Arnold y Yapita - junto a una tejedora aymara, Cipriana Apaza - han explorado las relaciones analógicas que existen entre el universo del tejido y la agricultura en Chukiñapi, Bolivia. Para los/as autores/as dichas analogías no son solo maneras de hablar o juegos de metáforas, sino que se trata de "un sistema de razonamiento, una manera de construir el mundo y luego entender las relaciones entre las diferentes dimensiones del mundo". (ARNOLD; YAPITA; APAZA, 1996, p. 410) Se trata de una misma red de significados que se revela mediante las analogías discursivas, y por qué no gestuales. Si pensamos al gesto como un modo de relación entre los elementos que lo componen (BARDET, 2019), la carne, para ser parte de la kalapurca o, mejor dicho, para ser kalapurca, debe ser previamente hervida y tizada, convertida "en hilitos". Lo mismo ocurre con la lana. Antes de ser tejido, la lana también debe ser tizada e hilada. El hilo se presenta, entonces, como la unidad mínima de sentido en ambos campos.

En cuanto al uso de instrumentos, anteriormente mencionamos que la herramienta se vuelve inseparable del gesto que la hace eficaz. En la vida cotidiana de las mujeres cuseñas (como en la vida cotidiana de quienes cocinamos en el hogar), los utensilios y elementos de cocina acompañan 
a los gestos y biografías de cada cocinera. En su cocina, una conoce cuál cuchillo corta mejor, cuál cucharón funciona mejor de acuerdo con la preparación, qué olla emplear para la sopa y cuál para el puchero, entre otras. Pero, ¿qué ocurre cuando el cocinar es colectivo y los instrumentos no son los conocidos o los deseables? En esta kalapurqueada pudimos observar con asombro el esmero y velocidad con la que se resolvía la falta del instrumento adecuado. A falta de tablas o mesadas, se usaron escritorios averiados y tablones, a falta de cucharones, palos de viejas escobas y, a falta de buenos cuchillos, se trajeron los propios. Todas estas modificaciones ante las técnicas habituales implicaron modificaciones en los gestos y la corporalidad de las cocineras.

En el 2018, por ejemplo, la mesa que se consiguió era muy bajita y pequeña, por lo que debían turnarse de a una o dos para picar los ingredientes del estofado. Ambas picadoras sentadas en un banquito improvisado. Este año, la altura de las tablas y escritorios impidió la posibilidad de que alguna se sentara, pero su tamaño permitió la colaboración de varias cocineras en simultáneo. A nosotras, por ejemplo, esto nos facilitó no solo la conversación con ellas sino también la imitación de la técnica de cortado (cómo tomar el cuchillo, el tamaño y grosor de cada rebanada del vegetal cortado, dónde y cómo amontonar lo ya picado para su posterior uso). Por último, en cuanto al rallador defectuoso (indispensable para preparar la yasgu $\left.a^{11}\right)$, su uso implicó una readaptación de la técnica del rallado: había que sujetarlo con mucho cuidado para no lastimarse y había que ejercer mayor fuerza para que el tomate sea efectivamente transformado en puré.

\section{COCINA COMO PRÁCTICA DE MEMORIA}

Mediante las entrevistas, hemos preguntado a todas las mujeres si sabían hacer kalapurca, a lo que contestaban que sí. Las más jóvenes hacían este plato en grupo, nunca solas. Todas narraban que antes esta comida se hacía con piedritas calientes, de allí su nombre. Pero que ahora ya no. Las explicaciones de por qué se usaban antes estos elementos fueron muy variadas.

11 También conocida como llajwa o llasjua, es una salsa picante preparada a base de una variedad de ají llamada locoto y tomate triturado. Se le puede agregar sal y, según la región, cebolla picada, yerba buena, perejil o kirquiña (similar al cilantro). Se consume en Bolivia, el noroeste argentino y norte de Chile. 
Algunas nos dijeron que debía darle sabor a la comida, otras que mantenía el calor del plato. Candelaria fue más determinante, nunca preparó ella misma la kalapurca con piedras, pero la probó y no le sintió diferencia en el gusto. “Además, quién tiene el tiempo hoy en día”, sentenció. El tiempo se refleja en la receta a través de aquel ingrediente ausente, las piedras. El sabor del pasado se encuentra entramado en cada plato que se sirve y relata su propia historia, esta vez en la ausencia, en la reflexión sobre el cambio con respecto a otros tiempos.

Pero la narración no agota esta transmisión. ¿Qué pasa cuando el pasado se narra de otra manera? Porque no solo aprendemos a cocinar a partir de las recetas narradas. Aprendemos en la práctica, mirando cómo cocinan otros. Copiamos movimientos, gestos, aprendemos cómo condimentar, qué ingredientes usar, cuándo agregar agua o sacar la olla del fuego. Dentro del universo de prácticas de cocina que hemos incorporado a lo largo de nuestra vida, por ejemplo, la carne tizada no forma parte de nuestro repertorio. El tizado requiere de un gesto aprendido (e incorporado), que nuestros dedos no han practicado, que no nos han enseñado. Las cocineras cuseñas lo hacían con naturalidad. Buscaban en ese hacer un producto final específico, que nuestras manos no lograban terminar de comprender. El pasado y la historia de la comida se narra en las prácticas culinarias, en el gesto utilizado para cortar la cebolla, en el tizado de la carne de llama, en la forma de revolver el mote. Se narra de forma distinta al discurso.

Finalmente, tras los dos primeros acercamientos pudimos comenzar a entender (no solo con la mente sino también con el cuerpo) cuál era el sabor de la kalapurca cuseña. Descubrimos que éste sintetiza el arduo trabajo de pastoreo; la historia de vida de las ollas que intervinieron en la cocción; el sonido del agua del río Cusi; las tonalidades rojizas y amarillas de los cerros; las melodías ejecutadas por los sikuris desde los primeros encuentros en la "Iglesia Vieja" del pueblo. Además, sintetiza todas las kalapurqueadas del 3 de mayo, pero también de todas las Señaladas y Todos Los Santos. Al mismo tiempo, el sabor de la kalapurca cuseña articula los diferentes paisajes de origen de sus ingredientes constituyentes y que consideramos son un reflejo de la lógica de movilidad pastoril. (CARRERAS; PEY, 2019)

Sin embargo, aunque aún se encuentran todos aquellos elementos y significados, el sabor de esta kalapurca se nos presenta distinto. Es diferente 
en tanto existen otras kalapurcas con las que compararlo. En esta ocasión, encontramos que su sabor tiene mezclado entre sus hilitos de carne, entre el mote y el caldo, el calor del día y el frío de la noche cuseña. Sabe a tres días maratónicos de cocinar sin descanso; a esas noches de dormir poco y planificar mucho. Tiene el sabor de una organización diferente, con mujeres jóvenes a cargo. A muchos platos siendo preparados al mismo tiempo, compartiendo el fuego dibujado por el continuo ensamblaje de ladrillos huecos. Al humo cuyo olor permanece en las ropas mucho tiempo después para recordarnos dónde hemos estado. Sabe al entusiasmo de recibir y agasajar a mucha gente. Y un poco, también a las antropólogas "gringas" que, aunque sin buena técnica, pero con mucho esmero, intentaron tizar carne por primera vez en sus vidas culinarias.

Tras todo lo narrado, y a modo de reflexión final, podemos afirmar que no todas las historias se cuentan con palabras. En Cusi Cusi, los gestos que hacen a la kalapurca ayudan a construir y sostener las historias del mundo que habitan sus pobladores/as, y estos gestos, cada 3 de mayo, están en manos de las mujeres. Así, la kalapurca se compone de "acciones de mujeres, voces de mujeres que hacen habitable la tierra” ya que, en la cocina, las cuseñas "trabajan para dar forma al mundo" (GIARD, 1999, p. 229), para contarnos su versión de la historia. Una historia que, gesto a gesto, nos narra a sus madres, abuelas y ancestras, hasta llegar a aquella primera olla donde hirvió, entre piedras, el primer caldo de kalapurca.

\section{REFERENCIAS}

ALBERTI, B. Cut, Pinch and Pierce: image as practice among the early formative la candelaria, first millennium ad. In: DANIELSSON, M. B.; FAHLANDER, F.; SJOSTRAND, Y. (org.). Encountering imagery: materialities, perceptions, relations. Stockholm: Stockholm Studies in Archaeology, 2012. p. 13-28.

ALONSO, L. E. Sujeto y discurso: el lugar de la entrevista abierta en las prácticas de la sociología cualitativa. In: ALONSO, L. E. La mirada cualitativa en sociologia: una aproximación interpretativa. Madrid: Fundamentos, 2003. p. 67-88.

ARNOLD, D.; YAPITA, J. D.; APAZA, C. Mama trama y sus crías: analogías de la producción de la papa en los tejidos de Chukiñapi. In: ARNOLD, D. Y.; YAPITA, J. D. Y. (comp.). La madre melliza y sus crías: una antología de la papa. La Paz: Hisbol: ILCA, 1996. p. 373-411.

BARDET, M. Hacer mundos con gestos. Buenos Aires: Cactus, 2019. 
PROCESO del tizado, lana de oveja. [S. l.: s. n.], 2017. 1 vídeo (25 seg). Publicado pelo canal Benyelin Sofia Meneses Burbano. Disponível em: https://www.youtube. com/watch?v=BomJOTM_6Qg. Acesso em: 12 out. 2018.

CÁRDENAS-CARRIÓN, B. M. Construcciones culturales del sabor: comida rarámuri. Anales de Antropología, Ciudad de México, v. 48, n. 1, p. 33-57, 2014.

CARRERAS, J.; PEY, L. Explorando las formas de cocinar una kalapurca en Cusi Cusi (Puna de Jujuy): etnografía de un plato andino. Antropologías del Sur, Santiago, v. 6 , n. 12, p. 39-59, 2019.

CERRÓN-PALOMINO, R. Carapulca. Boletín de la Academia Peruana de la Lengua, Lima, v. 41, p. 149-165, 2006.

CITRO, S. La multiplicidad de la práctica etnográfica: reflexiones en torno a una experiencia de campo en comunidades tobas. Cuadernos del Instituto Nacional de Antropología y Pensamiento Latinoamericano, Buenos Aires, v. 18, p. 91-107, 1999.

GIARD, L. Hacer de Comer. In: CERTEAU, M.; GIARD, L.; MAYOL, P. La invención de lo cotidiano. Ciudad de México: Universidad Iberoamericana y Biblioteca Francisco Xavier Clavigero, 1999. p. 151-256. (Série Habitar, cocinar, t. 2).

HAUDRICOURT, A. Des gestes aux techniques: essai sur les techniques dans les sociétés pré-machinistes. París: Édition de la Maison des Sciences de l'Homme, 2010 .

HEIDEGGER, M. Ser y Tiempo. Madrid: Trotta, 2009.

LE BRETON, D. El sabor del mundo: una antropología de los sentidos. Buenos Aires: Nueva Visión, 2007.

LEROI-GOURHAN, A. El medio y la técnica. Madrid: Taurus, 1989.

LÉVI-STRAUSS, C. Introducción a la obra de Marcel Mauss. In: MAUSS, M. Sociología y Antropología. Madrid: Tecnos, 1979. p. 13-24.

MAUSS, M. Técnicas y movimientos corporales. In: MAUSS, M. Sociología y Antropología. Madrid: Tecnos, 1979. p. 337-356.

MERLEAU-PONTY, M. Fenomenología de la percepción. Barcelona: Planeta Agostini, 1993.

MONTECINO, S. Cocinas Mestizas de Chile: la olla deleitosa. Santiago de Chile:

Santander Santiago y Museo Chileno de Arte Precolombino, 2004.

MONTECINO, S. De piedras y cocciones: calapurca. Patrimonio cultural, Concepción, n. 42, p. 20-21, 2007.

MONTECINO, S. Piedras, mitos y comidas: antiguos sonidos de la cocina chilena: la calapurca y el curanto. Atenea, Concepción, n. 487, p. 33-49, 2003.

PAZZARELLI, F. La importancia de hervir la sopa: mujeres y técnicas culinarias en los Andes. Antípoda, Córdova, n. 10, p. 157-181, 2010. 
SILLAR, B. The Dead and the Drying: techniques for transforming people and things in the Andes. Journal of Material Culture, London, v. 1, n. 3, 259-289, 1996.

VAQUER, J. M.; CÁMERA, Y. Las relaciones entre el paisaje, las narrativas y la praxis arqueológica en Cusi Cusi (Rinconada, Jujuy): una mirada hermenêutica. Revista del Museo de La Plata, La Plata, v. 3, n. 1, p. 38-56, 2018.

VAQUER, J. M.; PETIT DE MURAT, F.; DI TULLIO, M. Prácticas, narrativas y temporalidad en Cusi Cusi (Rinconada, Jujuy): una mirada hermenéutica. Andes, Salta, 2018. No prelo.

WEISMANTEL, M. J. Alimentación, género y pobreza en Los Andes ecuatorianos. Quito: Abya-Yala, 1994.

WRIGHT, P. Experiencia, intersubjetividad y existência: hacia una teoría práctica de la etnografia. Runa, Buenos Aires, v. 20, p. 347-380, 1994. 


\title{
DINÂMICAS CULTURAIS NAALIMENTAÇÃO DA FORMAÇÃO DAS COZINHAS À CONSTRUÇÃO DAS IDENTIDADES NACIONAIS DE BRASIL E PORTUGAL ${ }^{1}$
}

\author{
TALITA PRADO BARBOSA ROIM
}

\section{INTRODUÇÃO}

No mundo em que vivemos atualmente, cada vez mais globalizado e conectado, debates sobre regionalismos, nacionalismos e identidades nacionais têm retornado ao campo de debates das ciências sociais e humanas a fim de pensar sobre diferentes rumos políticos e caminhos econômicos que os diferentes países, em suas diferentes conjunturas, têm tomado como medidas de políticas internacionais, bem como de políticas públicas para o desenvolvimento interno e externo dessas nações, como por exemplo, alimentação adequada e soberania e segurança alimentar e nutricional (SSAN).

1 Esse texto faz parte da pesquisa financiada pelo Programa Nacional de Pós-Doutorado da Coordenação de Aperfeiçoamento de Pessoal de Nível Superior (PNPD-CAPES) no Programa de Pós-Graduação em Antropologia Social da Universidade Federal de Goiás. 
Discutir tais temas tornam-se necessários na medida em que movimentos políticos e sociais que estariam aparentemente superados, retornam à baila com força e intensidade nas posições conservadoras que alguns países centrais dentro política internacional vêm aderindo e reafirmando.

A partir dessa realidade que nos apresenta, justifica-se a escolha do tema da formação de Estados-nações e construção de identidades e cozinhas nacionais. Entender os processos pelos quais Brasil e Portugal passaram para chegar às suas configurações sociais atuais é importante para refletir e analisar o tempo presente. De modo que, voltar à história do Brasil, à formação do pensamento social, aos projetos de formação da nação brasileira e de identidade nacional se fazem úteis para rever e rediscutir "o que faz o brasil, Brasil”. (DAMATTA, 1986) ${ }^{2}$

Os projetos políticos de configuração de nação são construções sociais mediadas pelos interesses políticos e culturais de cada período e contexto sócio-histórico. Dentro de uma perspectiva antropológica, baseando-se em Benedict Anderson (2008) tomamos como conceito “[...] a seguinte definição de nação: uma comunidade política imaginada - e imaginada como sendo intrinsecamente limitada e, ao mesmo tempo, soberana”. (ANDERSON, 2008, p. 31)

Nesse sentido, as comunidades se distinguem não porque são falsas ou autênticas, mas porque têm estilos diferentes de serem imaginadas, pensadas e, também de serem percebidas e vividas. Para Anderson (2008), a nação é imaginada como soberana porque o conceito nasce no Iluminismo, momento histórico em que revoluções estavam ocorrendo na Europa, questionando e destruindo a legitimidade dos reinos dinásticos hierárquicos de ordem divina. Dessa maneira, a ideia do que seja nação é imaginada como uma comunidade soberana e seus aspectos legitimadores.

Assim, a soberania é conseguida por meio do Estado e sua consolidação seja pela via política (normatizações, leis, regras sociais), seja pela via cultural (língua, costumes, vestimentas, cozinha). São os elementos cotidianos legitimados pelo Estado que permitem enaltecer o que é diferente e específico em cada nação e o que lhes é motivo de orgulho, formando identidades.

2 Parafraseando a obra do autor Roberto DaMatta O que faz o brasil, Brasil? (publicado originalmente em 1986), especialmente na diferenciação que o autor faz ao conceituar alimento e comida. 'O alimento é algo universal e geral, diz respeito a todos os seres humanos [...]. Comida se refere a algo costumeiro e sadio, alguma coisa que ajuda a estabelecer uma identidade, definido, por isso mesmo, um grupo, uma classe, ou pessoa'. (DAMATTA, 1991, p. 55) 
Os frutos culturais do nacionalismo - a poesia, a prosa, a música, artes plásticas - mostram esse amor com muita clareza, e em milhares de formas e estilos diversos. Por outro lado, como é difícil encontrar frutos nacionalistas semelhantes expressando medo e aversão. (ANDERSON, 2008, p. 200)

Para ser possível analisar a constituição da cozinha brasileira e a eleição dos ingredientes e pratos típicos que a compõem, proponho a reflexão sobre a relação entre Brasil e Portugal, em uma perspectiva teórica que nos permita relacioná-las com as noções de colonizador e colonizado dentro de um processo de trocas culturais, em que os dois países se envolvem mais intensamente entre o período histórico e político do processo de descolonização ao império, da independência à formação da república no Brasil e, consequentemente, seus desprendimentos e novos entrelaçamentos com a nação portuguesa.

Assim, proponho pensar na tríade - nação, alimentação e literatura relacionando-a com o resgate histórico do Brasil Imperial e de Portugal no período colonial, e suas representações em obras de literatura clássica - Eça de Queiros e Machado de Assis -, admitindo que em uma perspectiva antropológica é possível “[...] submeter conceitos preestabelecidos à experiência de contextos diferentes e particulares, assim ela [a antropologia] procura dissecar e examinar, para então analisar a adequação de tais conceitos”. (PEIRANO, 1990, p. 3, grifo nosso)

Diante de tal método pretende-se reconstruir os caminhos da formação da cozinha brasileira e da cozinha portuguesa como elementos fundadores de identidades nacionais, formulando uma ideia de nacionalidades construídas pelas diferenças. (HALL, 2004)

\section{LITERATURA, ALIMENTAÇÃO E FORMAÇÃO DE NAÇÃO}

O comportamento relativo à comida liga-se diretamente ao sentido de nós mesmos e à nossa identidade social, e isso parece valer para todos os seres humanos. (MINTZ, 2011, p. 31)

Portugal tem o papel de país civilizador no processo de desenvolvimento da nação brasileira, porém tal posição vai sendo trocada e muitas vezes invertida ao longo dos entrelaçamentos culturais e políticos com o 
Brasil. Os marcos históricos das trocas culturais aqui enfatizados se referem à chegada da corte portuguesa em 1808 e, a partir de então, o caminho percorrido para a independência (1889) e a formação da Primeira República brasileira (1889-1930).

As trocas culturais entre Brasil e Portugal são intensas, complexas, controversas e congregam situações pertinentes para a consolidação das duas nações, bem como suas identidades nacionais e reconhecimento enquanto países autônomos que, a partir de questões políticas desempenham aspectos importantes para concretização de suas cozinhas e, em consequência, dos projetos de legitimidade da nação.

Nos detemos nesse momento à análise de alguns aspectos da vida e obra de dois representantes da intelligentsia portuguesa e brasileira do período, ${ }^{3}$ tanto de Machado de Assis, eleito por alguns, mas discutidos por outros, ${ }^{4}$ como um dos intelectuais a formar o pensamento social genuinamente brasileiro; e Eça de Queirós, intelectual português que para além da obra literária, ocupou cargos políticos e teve relação direta com o Brasil via textos jornalísticos publicados em jornal do país.

Tais aspectos serão tratados nessa sessão a fim de criarmos caminhos possíveis para articular o que sugerimos como objetivo a ser discutido: formação de cozinhas nacionais como aspectos importantes na construção e consolidação de estados nacionais.

O objetivo é estudar os processos (ELIAS, 2011) de construção de identidades nacionais dos dois países sob o viés do cotidiano alimentar e a formação de suas cozinhas, buscando diferentes fontes de dados: literatura; ciência; documentos históricos; representações socioculturais. "A identidade nacional, como todo processo de construção de identidade, tem uma dimensão interna na qual se acentuam os traços de similaridades, ao mesmo tempo, uma dimensão externa, que define uma diferença em relação ao outro". (OLIVEIRA, 1990, p. 11-12)

3 Interseccionando o período histórico abordado nesse capítulo (1808 e 1930) com o período de vida e de morte de Eça de Queirós (1845-1900) e de Machado de Assis (1839-1908).

4 Existem discussões sobre a produção literária de Machado de Assis e de suas influências estrangeiras, porém não cabe aqui entrar nesse embate por não ser o foco no momento. Para aprofundar essa discussão, consultar o artigo de João Hernesto Weber do ano 2003, intitulado Machado: do discurso romântico da nacionalidade à crítica radical da nação. 
As trocas materiais de produtos e modos de fazer entre a cozinha portuguesa e a cozinha brasileira contribuem para a formação das identidades nacionais, posto que se encontram entrelaçadas - ora mais, ora menos nos processos políticos e econômicos dos dois países.

A afirmação de papel simultâneo de colonizador e colonizado de Portugal sustenta a análise sobre as relações estabelecidas entre o Brasil e o processo de independência e Primeira República. Portugal enquanto país colonizador, que ditava leis, normas e regras às suas colônias possuía status político de Império, dominante sobre o Brasil, este status passa a se transformar no século XIX, quando D. João VI transfere a corte para o Brasil, tendo a cidade do Rio de Janeiro como capital do império português.

Em meados do século XVIII, novas ideias começaram a surgir. O príncipe regente português, D. João $\mathrm{V}$, centralizou a política de 'colonização' de todo o vasto império que se estendia da América do Sul ao sul da Ásia. Seu objetivo era convencer não portugueses a se estabelecerem no Brasil e, em 1748, apenas dois anos antes de sua morte, ele empregou um agente incumbido de trazer milhares de açorianos daquelas superlotadas ilhas do Atlântico para o extremo sul do Brasil e para o Pará, na foz do Rio Amazonas ao norte. Esses planos lançaram apena um modesto sucesso, mas lançaram a base para os futuros planos de colonização patrocinados pelo Estado. (LESSER, 2015, p. 35, grifo do autor)

A mudança geográfica da capital do Império português para o Brasil passa a ditar também transformações políticas, econômicas e socioculturais, destacando o aumento da imigração entre os dois países e o aumento das movimentações financeiras e das atividades econômicas.

Mediante esses fluxos, as trocas culturais também se intensificam. Em relação aos hábitos e técnicas alimentares evidenciam-se a doçaria, seus saberes e fazeres, as confeitarias e os usos do chá.

O hábito de tomar chá foi introduzido pela família real e tornou-se uma instituição no Rio de Janeiro. Homens de letras, políticos e famílias em geral chegavam às confeitarias em grande número para o 'five o' clock tea', horário após o qual não era de bom tom às mulheres de fino trato permanecerem no recinto. (BELLUZZO, 2010, p. 92, grifo do autor) 
Partindo da discussão sobre os mitos da formação da nação brasileira, temos como base da alimentação a carne seca, o feijão e a farinha de mandioca, tríade básica presente desde a chegada dos portugueses ao Brasil, conforme descrições de viajantes que visitaram o país, como Saint-Hilaire (de 1816 a 1822) e Debret (1815), que relataram sobre uma mistura de cozinhas, de seus instrumentos, ingredientes e os modos de fazer. (SILVA, 2005)

As quitandeiras serviam angu com miúdos de carne de vaca, coração, fígado, bofe, língua, moela [...] E a esse prato acrescentavam folhas de nabo, pimentão verde ou amarelo, salsa, cebola, louro e tomates; tudo reduzido à consistência de um molho de boa liga. (DEBRET, 2000 apud BELLUZZO, 2010, p. 32)

O fato é que a cozinha brasileira é complexa e passa por diferentes movimentos históricos, sociais e econômicos. A influência africana na formação do gosto, na escolha de ingredientes e na constituição de pratos e receitas é amplamente discutida, mas com muitas divergências. A partir da discussão sobre os mitos da "invenção da brasilidade" (LESSER, 2015), é possível chegar à questão central sobre culturas étnicas e o racismo no Brasil.

À medida que o Brasil passava de colônia de Portugal (1500-1822) a império independente (1822-1889), para em seguida se tornar república (de 1889 até o presente), uma série de processos levaram à criação de uma sociedade pluralista, com uma hierarquia racial que colocava a branquidão no topo e a negritude na base. A fluidez desses termos e de seus significados, entretanto, fizeram com que o Brasil se tornasse uma nação multicultural, embora seus cidadãos geralmente vissem a si próprios e a seu país como se tornando progressivamente mais brancos. Termos como branco, negro, europeu, índio e asiático (entre outros) não tinham significado fixo no contexto brasileiro. Pessoas e grupos entravam e saíam dessas categorias sempre mutáveis, e a identidade nacional brasileira, era em geral, simultaneamente rígida (a branquidão era consistentemente valorizada) e flexível (o significado de branquidão era maleável). (LESSER, 2015, p. 38)

Essa é uma discussão muito importante que deve ser cuidadosamente estudada e abordada em momento oportuno, porém não deixo de ressaltar 
que esse debate é central para compreensão sistêmica da formação da cozinha e a formação de nação e de identidade nacional brasileira. Da mesma forma é de igual importância analisar a herança da culinária indígena, do cultivo e saberes acerca da alimentação. ${ }^{5}$

Nessa elaboração e formas de reconstruir um ethos brasileiro e formas de se alimentar, endente-se que a construção da culinária se torna mais evidente no período da independência e depois, da república.

A discussão sobre a formação nacional, inclusive de nossa culinária, pode ser situada entre 1870 e 1930, quando envolveu nos debates as elites econômicas e os intelectuais de todo o país. As cozinhas regionais emergiram como tema a partir de 1920, e de maneira mais forte no Nordeste. O segundo aspecto que merece menção é que, quando dizemos 'cozinhas regionais', em geral, estamos nos referindo, com maior ênfase, às cozinhas populares. Nesse ponto, têm pouca importância, por exemplo, os livros de culinária que expressam modas internacionais e atravessaram o Atlântico, influindo na prática culinária das grandes cidades da América. Temos também uma evolução distinta, marcada em primeiro lugar pela violenta liquidação da população nativa e pela direção dada à alimentação negra pelos colonizadores. Ao chegarmos à segunda metade do século XIX, as elites nacionais estavam mais sensíveis ao processo internacional de afrancesamento culinário do que a descoberta do que 'valeria a pena comer' e incorporar as suas vivências, escolhendo pratos em meio a um vasto e desorganizado repertório de comidas populares. (DÓRIA, 2014, p. 148, grifo do autor)

Ao ultrapassarmos essa ideia limitadora das três raças na formação da cultura brasileira é possível pensar nos processos políticos, sociais, econômicos e culturais que levaram aos discursos e teorias racistas do final do século XIX e início do XX, como as teorias evolucionistas de branqueado da população brasileira e as políticas de migração europeia

5 De certo é um assunto vasto que nos encaminha para várias direções e questões fundamentais na formação do Brasil. Não pretendo de maneira alguma dar conta de tudo, por ser claramente impossível tratar de assuntos tão complexos em apenas um capítulo. Entretanto, pontuo que a partir do debate em torno da comida e da cozinha é possível discutir diferentes aspectos sociais e marcadores de diferenças, como raça, gênero, classe, dentre outros temas clássicos das ciências sociais, que são evidenciados ao longo do texto. 
para cumprir tal função, podemos aprofundar os debates sobre as práticas culturais e no conceito de processo civilizador cunhado por Norbert Elias (2011) na tentativa de compreender os discursos acerca da identidade nacional no Brasil.

As identidades que começam a surgir da necessidade de reordenar territórios, de constituir uma nação forte e independente passa a ser um movimento estratégico de regimes políticos que os tomam como meio de unificar os países. Falamos um pouco sobre a formação de cozinhas a partir da relação Brasil e Portugal. Tentemos agora, relacioná-las com a literatura, com a eleição de dois grandes nomes: Eça de Queirós e Machado de Assis.

Em Portugal, como em toda a Europa, movimentos e manifestações nacionalistas ocorreram nesse período de afirmação dos estados nacionais. José Maria de Eça de Queirós (1845-1900) assume este papel de nacionalista enquanto uma personalidade pública, em que sua vida social, bem como suas obras, abrangem o contexto da sociedade portuguesa.

Suas obras clássicas - Os Maias e o Crime do Padre Amaro, por exemplo - são reconhecidas e estudadas também no Brasil. Sua inserção no campo da literatura brasileira ocorre não somente pela origem do idioma, mas também de sua aproximação com o país como jornalista e com as viagens e textos que estreitaram os laços políticos, sociais e culturais entre Brasil e Portugal. Eça dedicou-se à escola literária realista com descrições amplas e detalhadas dos acontecimentos cotidianos da realidade portuguesa, dentre eles, os hábitos alimentares e os modos à mesa portugueses.

Eça de Queirós pertencia à classe intelectual burguesa de Portugal, ocupou cargos públicos e obteve reconhecimento na literatura, preocupou-se em descrever e criticar a sociedade de seu tempo, sendo que o Brasil também fez parte dessas preocupações. "Falar do Brasil, para ele, seria uma maneira de se falar também de Portugal, Antonio Candido - numa perspectiva brasileira - mostra então os impactos do ficcionista português em sua geração, que teve atuação decisiva na formação do pensamento crítico de nosso país”. (ABDALA JÚNIOR, 2000, p. 10)

Eça de Queirós firmou no Brasil a imagem de um libertário: a denúncia do que havia de podre na realidade, valendo-se do manto diáfano da fantasia, de acordo com suas palavras. Essa imagem foi construída por sua obra de ficção e por suas colaborações jornalísticas. Elza Miné discute, nesse sentido, intervenções de 
Eça que foram decisivas na configuração dessa personalidade, em que os gestos do artista confluíam para o do cidadão. Nesse diálogo Brasil-Portugal ouve querelas, como a que envolveu Eça e Machado. (ABDALA JÚNIOR, 2000, p. 10)

Candido conta que Gilberto Freyre nos anos de 1930 distribuiu questionários para pessoas nascidas pouco antes ou pouco depois da Proclamação da República a fim de coletar dados sobre escola, esportes, moda, literatura e convicções dessa população para compor seu livro intitulado Ordem e Progresso. ${ }^{6}$ Dentre as respostas destacou-se uma rede nacional de apreço à Eça de Queirós estendendo-se por gerações. "Eça era tão lido e querido, que o sociólogo [Freyre] chega a incluí-lo entre os que contribuíram para a unidade intelectual do Brasil”. (CANDIDO, 2000, p. 11, grifo nosso)

Segundo estudiosos contemporâneos do autor, a cozinha descrita por Queirós é uma cozinha burguesa.

O texto mais exemplar e programático sobre o tema talvez seja o artigo conhecido como 'Cozinha Arqueológica', publicado em 1893, na Gazeta de Notícias. Nele, Eça afirmou: 'a mesa constituiu sempre um dos fortes, se não o mais forte alicerce das sociedades humanas' e 'O caráter de uma raça pode ser deduzido simplesmente de seu método de assar a carne' (III, p. 1226). A declaração ressalta a intrínseca relação entre comida e sociedade, que Eça reforça, ao adicionar: 'a cozinha e adega exercem uma tão larga e direta influência sobre o homem e a sociedade', por isso 'dize-me o que comes, dir-te-ei o que és' (III, p. 1226). (ANDRADE, 2015, p. 205, grifo do autor)

As obras e textos de Eça de Queirós são permeadas de descrições de pratos, jantares e banquetes que apontam os hábitos da época e as distinções sociais como marcadores de diferenças e construção de identidade, vindo ao encontro de estudos como os do próprio Elias $(2011)^{7}$ e os do antropólogo José Sobral (2007) que escreve sobre a cozinha portuguesa dividida a

6 Ordem e Progresso foi publicado originalmente em 1957. Para maiores informações consultar a obra de Freyre (2010).

7 Elias (2011) afirma que os modos de destrinchar a carne também é um aspecto do processo civilizador na sociedade de corte. Consultar a Parte IV Dos Modos à Mesa, presente no capítulo 2 (A civilização como transformação do comportamento humano). 
partir do contexto de classes, da cozinha burguesa, refinada e influenciada pelo processo civilizador da alta cozinha francesa e; da cozinha popular, rústica e simples, baseada nos hábitos regionais de pescadores e trabalhadores rurais do país.

As tramas de Eça de Queiroz em que aparecem trufas e ostras são cenários de luxo e requinte, onde tais alimentos - assim como também champanhes, Portos de determinada safra, produtos com excelência determinada pela referência geográfica, como as ostras de Marennes ou peixe da Dalmácia, ou pela raridade, chá de Naipó - aparecem como símbolo de distinção de classe, símbolos do gosto burguês. (SILVA, 2012, p. 29)

Eça tinha um grande interesse pelo Brasil pois via o país como uma extensão de Portugal devido o processo de colonização. Fato é que Eça nunca veio ao Brasil, mas conquistou a população brasileira de sua época a partir de seus escritos jornalísticos bem como suas obras literárias. O escritor português teve mais leitores aqui do que em seu país de origem. "Esse fato se explica pelo entrecruzamento das expectativas do escritor e seu público-leitor, entre estes e os mediadores críticos. Eça, republicano encontrava no Brasil formas de poder simbólico identificadas com o republicanismo que se respaldavam em esferas do poder político, fato que não ocorria em Portugal e sua monarquia decadente". (ABDALA JÚNIOR, 2000, p. 99)

Esse escritor fez-se tradição no Brasil, isto é, suas atitudes estético-literárias associaram-se a um habitus libertário, um modelo de pensamento-ação que sensibilizou a intelectualidade do país até a metade do século XX. Em algumas regiões brasileiras, como no Nordeste, sua produção soava subversiva mesmo nos anos da ditadura militar iniciada em 1964. O papel político de Eça no Brasil foi destacado por Paulo Cavalcanti, um dos mais entusiastas queirosianos brasileiros, em seu texto clássico Eça de Queirós, agitador no Brasil. (ABDLADA JÚNIOR, 2000, p. 100)

Abdala Júnior (2000) afirma que Eça era visto como escritor suspeito, inclusive no século XX como foi indicado acima, tanto em Portugal como no Brasil, um dos motivos era por defender ideais anti-imperialistas, 
influenciando autores brasileiros, como Graciliano Ramos, em relação às iniquidades da vida social brasileira.

$\mathrm{O}$ autor português criticou o discurso nacionalista conservador de Portugal e simpatizou com as políticas republicanas do Brasil. Em seu Brasil imaginário defendeu o brasileiro e sua identidade nacional, ainda que suas descrições eram por vezes limitadas e preconceituosas.

A carreira jornalística de Eça de Queirós no Brasil iniciou-se em 1880 na Gazeta de Notícias, com intervalos nas publicações entre 1883 e 1886, e um novo silêncio entre 1889 e 1991, retorna em janeiro de 1892 permanecendo até 1897.

O conjunto de matérias enviadas para o Rio de Janeiro constitui-se, assim, no que se pode considerar a obra jornalística de Eça de Queirós, pensada e elaborada tendo em vista o público brasileiro, por meio de um mesmo e único vínculo - a Gazeta de Notícias -. Este jornal desempenhou um papel de fundamental importância na impressa brasileira no último quartel do século XIX e início do século XX. (MINÉ, 2000, p. 43)

Miné (2000, p. 46) ainda diz que "em termos contemporâneos, poderíamos, sem dúvida, considerar Eça de Queirós um dos grandes “colunistas” da Gazeta de Notícias, notabilizando-se entre aqueles que, no Brasil, construíram essa espécie jornalística, com nível e brilho”.

No contexto brasileiro, Joaquim Maria de Machado de Assis, considerado um dos maiores escritores brasileiros, nasceu no Rio de Janeiro em 1839 e morreu em 1908, na cidade natal. Possui ampla obra literária em diversos estilos, dentre eles os contos e os romances, possui também textos de opinião pública sobre a conjuntura do país de sua época. (MAGALHÃES JÚNIOR, 2008)

Diferentemente de Eça de Queirós, Machado não se dedicou a grandes descrições acerca da alimentação ou das maneiras à mesa. Pelo contrário, criticou essas características na obra O Primo Basílio de Eça, afirmando ser exagero as descrições gastronômicas, vendo como um problema cultivado pela escola realista de literatura. (FANTINI, 2012)

Apesar de as obras de Machado não conter as riquezas de detalhes de pratos, costumes à mesa etc., mesmo que discretamente, os mencionou em seus trabalhos, e os apreciou em vida. Belluzzo (2010) descreve o seu apreço 
por boa comida e hábitos à mesa em suas visitas as padarias e confeitarias do Rio de Janeiro, uma clara influência da corte portuguesa no Brasil, ao mesmo tempo em que o autor reconhecia os contrastes do país, uma vez que Machado vivenciou, bem como analisou e foi um crítico de acontecimentos políticos importantes do país. "Foram momentos de efervescência social, sobretudo em virtude da abolição da escravatura”. (BELLUZZO, 2010, p. 83)

Dentre as importantes ocorrências dessa questão, a autora menciona alguns marcos importantes, como por exemplo, a proibição do tráfico negreiro em 1850, a Lei do Ventre Livre promulgada em 1871 e a própria Abolição em 1888, registrado por Machado no trecho da seguinte crônica.

Houve sol, e grande sol, naquele domingo de 1888, em que o Senado votou a lei, que a regente sancionou, e todos saímos à rua. Sim, também eu saí à rua, eu o mais encolhido dos caramujos, também eu entrei no préstito, em carruagem aberta [...]; todos respiravam felicidade, tudo era delírio. Verdadeiramente, foi o único dia de delírio público que me lembro ter visto. (ASSIS, 2008 p. 938 apud BELLUZZO, 2010, p. 83)

Ainda, é possível perceber que Machado se posicionou em defesa aos hábitos e costumes brasileiros no sentido tal de pensar questões sobre nacionalidades. Machado de Assis expressou sua visão política acerca da nação brasileira em diversos textos de modo subjetivo e como crítica social, ao defender que um escritor é fruto de seu tempo e espaço, o que expressa traços de um pertencimento nacional e de uma literatura que defende o nacionalismo. (FANTINI, 2012)

Machado apresenta pequenos lampejos sobre costumes alimentares como distinção social em alguns de seus romances, como no caso de Memórias Póstumas de Brás Cubas, em que o personagem principal mostra as distinções sociais nas relações entre senhores e escravos, na divisão da casa enquanto espaço privado, onde a cozinha praticamente faz parte da senzala e não das dependências em que seus proprietários circulam.

Ou ainda, quando se refere aos banquetes dos senhores descrevendo os aparelhos de jantar refinados, os talheres e castiçais de prata importados de Portugal. E, também, quando descreve sobre a confecção de doces em compota de frutos típicos do país, como o doce de coco, as marmeladas, o melado e o cará. (ASSIS, 1994) 
$\mathrm{O}$ autor também contribuiu em jornais e periódicos brasileiros, como por exemplo, Jornal das Famílias (1863), Ilustração Brasileira (1878), O Cruzeiro (1878); Gazeta de Notícias (1888 a 1893), Imprensa Fluminense (1888), escrevia sobre diferentes comportamentos, tendências e modismos que se passavam na metrópole, criticando a elite, mesmo participando dela.

A novidade dos restaurantes requintados atendia uma clientela seleta com 'menus' em francês que ofereciam magníficas ofertas de iguarias estrangeiras elaboradas com todo o esmero. Eram oásis gastronômicos que prosperaram, porém ficavam restritos a um público europeizado e exigentes. Porém, como Machado bem sabia, o 'banquete da vida', fosse ele habitado por iguarias nacionais ou estrangeiras, nem sempre era 'uma delícia' para seus contemporâneos. A grande maioria da população livre e dos escravos alimentavam-se de feijão, carne seca, farinha de mandioca, pirão e angu, comida essa que não experimentou quaisquer aperfeiçoamento e os requintes granjeados pelas mesas mais favorecidas, ao longo de praticamente todo o século XIX e início da jovem República. (BELLUZZO, 2010, p. 144, grifo do autor)

Podemos perceber que Machado de Assis foi um crítico da sociedade brasileira e como homem de seu tempo preocupou-se em compreender o processo histórico ao qual estava inserido e, ainda que compartilhasse de uma posição privilegiada, mantendo um status social elevado, frequentando teatros, confeitarias e restaurantes de preços elevados e pouco acessíveis. $\mathrm{O}$ autor tinha consciências das desigualdades sociais do Brasil e contribuiu para a construção da crítica de determinados comportamentos e tendências adotados na sociedade brasileira.

A aparente opulência representada pela sofisticação dos costumes gastronômicos das elites não atenuou (nem poderia fazê-lo) a melancolia machadiana, ou seja, ela em relação à condição humana em geral, seja ela em relação à situação social do Brasil. Com esse pano de fundo, talvez a típica reação de Machado de Assis aos feéricos cardápios que presenciou fosse a de 'ajuntar os restos de festim, mandar fazer o que a arte culinária chama roupa velha, e comê-la com os amigos, sem vinho'. (ASSIS, 2008, p. 948 apud BELLUZZO, 2010, p. 144, grifo do autor) 
Compreende-se que o processo de construção do discurso sobre identidade ou cultura brasileira pode partir de duas situações: do campo científico para o senso comum; ou do senso comum para o campo científico; “ $[. .$.$] o$ importante a ressaltar é a interação entre cultura erudita e cultura popular e a circulação de ideias”. (OLIVEN, 1989 apud OLIVEN, 2002, p. 16)

Ainda, conforme Mintz (2003), as comidas de um país são antes que nacionais, regionais. Isso é fato, tanto no Brasil quanto em Portugal, pois são nas localidades e nas regiões que o cotidiano transcorre e se desenvolve e, consequentemente, formam no regional o que lhes é nacional.

Machado e Eça foram contemporâneos e em várias circunstâncias suas vidas e obras se entrecruzaram, com críticas de um a outro, de posicionamentos sobre a política e a literatura. Os autores como homens de seu tempo, vivenciando a conjuntura histórica e cultural do Ocidente sobre a consolidação dos Estados-nações e suas expressões nacionalistas perante o resto do mundo para travar disputas entre poderes políticos, econômicos e culturais.

Os dois autores traçaram uma trajetória pública para além do ofício de escritor com envolvimento político e opiniōes sobre os projetos nacionais. A relação entre eles não era harmoniosa, trocavam duras críticas.

Um dos grandes agentes a aquecer o polêmico cenário do nosso jornalismo oitocentista é o escritor português Eça de Queirós, que, do outro lado do Atlântico, colabora em periódicos brasileiros. Nesse contexto, irrompe um clima de mal-estar entre Eça e Machado de Assis, quando este decide responder de viés ao que acredita ser um desrespeitoso motejo daquele em relação aos brasileiros em geral, ao imperador do Brasil e, particularmente, ao próprio Machado. (FANTINI, 2012, p. 113)

Machado e Eça debatiam opiniões e publicavam suas provocações e suas respectivas respostas nos jornais brasileiros, indicando uma disputa por legitimidade de expressão no e sobre o país, de suas representações, de suas condutas políticas e formação do estado brasileiro e sua literatura. As críticas vinham desde os estilos de escrita de um e de outro, bem como de posicionamentos políticos. Dentre eles, a formação do Brasil e do povo brasileiro. Eça em determinados textos e contextos inferiorizou o Brasil e os brasileiros com insultos ao imperador e ao próprio Machado. 
As trocas de informações eram intensas nesse momento de transição de império para república. Assim também o era nas trocas materiais, de produtos e modos de fazer entre a cozinha portuguesa e a cozinha brasileira contribuindo também para a formação das identidades nacionais, posto que se encontram entrelaçadas - ora mais, ora menos - nos processos políticos e econômicos dos dois países. Braga (2010) aponta para o desenvolvimento desse tipo de comércio em Portugal e da sua aceitabilidade por parte dos portugueses.

Sabendo-se que, à medida que os portugueses se foram fixando no Brasil, levaram seus hábitos e costumes alimentares, mas que estes tiveram que ser adaptados à realidade do novo espaço, não é de se estranhar que a trilogia alimentar no Brasil colonial tenha sido diferente. Isto é, à metropolitana carne, pão e vinho contrapõe-se a colonial carne (seca), feijão e mandioca. Se, por regra, se pode destacar abundância de carne (verde ${ }^{8}$ ou seca), de peixe (fresco ou seco) e, sobretudo, de frutas, não é menos verdade que tais alimentos não chegavam a todos e que o Rio de Janeiro era um espaço bastante bem abastecido. (BRAGA, 2010, p. 167)

\section{DINÂMICAS CULTURAIS E FORMAÇÃO DAS COZINHAS DE BRASIL E DE PORTUGAL}

Traçar a formação da identidade nacional e aspectos da civilização brasileira por meio do estabelecimento de sua cozinha, na escolha, por vezes arbitrárias e outras por interesses políticos e econômicos, de produtos, ingredientes e de pratos típicos, torna-se possível entender a cozinha como elemento cultural e político na construção de identidades nacionais. A culinária pode ser duplamente considerada como marcador de identidades, tanto para o discurso oficial quanto para as vivências cotidianas de pessoas comuns. É um dos elementos em que cozinhas, receitas, pratos são classificados como nacionais para legitimar um país, um governo ou diferentes tipos de

8 Carne verde é uma expressão utilizada em Portugal, mas também no Brasil - sobretudo em textos do século XIX e início do século XX - para referir-se à carne fresca in natura. 
interesses, como de unificação, ou até mesmo separação de territórios. Ao mesmo tempo em que é um dos aspectos mais fortes em relação ao reconhecimento e pertencimento de um grupo.

Os traços de aproximações das construções de identidades nacionais entre os dois países são acentuados por meio dos hábitos e costumes regionais. (OLIVEN, 2002) No caso de Portugal, José Manuel Sobral (2007) ao analisar o histórico das receitas e dos produtos utilizados para a confecção de pratos típicos, relacionando-os às observações de campo que realizou em um festival de comidas típicas na região de Ribatejo, ${ }^{9}$ percebe dois principais contrastes das regularidades regionais: o primeiro trata-se dos elementos utilizados na região litorânea do país, relacionados à pesca e aos elementos utilizados no mundo agrícola; e o segundo contraste seria o das diferenças e oposições entre norte e sul do país. Assim, o autor percebe que o Festival é "[...] uma festa que exalta as especificidades regionais constitutivas do todo nacional”, e define (assim como Oliven (2002) aponta no caso brasileiro) que nessa situação "o nacional é o regional”. (SOBRAL, 2007, p. 25)

No Festival os aspectos regionais são representados pelos elementos que constituem o universo rural e os que constituem o universo da pesca em Portugal, que atualmente encontra-se em declínio e, em alguns casos, até mesmo desapareceu.

Os símbolos escolhidos para representar o país no Festival são os mesmos símbolos que foram utilizados nos projetos nacionais do Estado Novo de Portugal. ${ }^{10}$ Por sua vez, o Estado Novo utilizou-se dessas representações que serviram como dispositivo para legitimar uma identidade nacional, propondo no discurso oficial identificar uma cultura nacional genuína junto às massas populares.

Essas representações referiam-se aos trabalhos desenvolvidos nas zonas rurais e marítimas, como a agricultura e a pesca, importantes para a economia do país pré-industrial do século XIX, exaltando os trabalhos manuais, o artesanato e os saberes tradicionais das regiões, relacionando-as à ideia de nação, de um país unificado e majoritariamente rural.

9 Trata-se do XXIV Festival Nacional de Gastronomia, que teve lugar em Santarém em 2004, estudado por Sobral (2007) na busca por compreensão do processo de formação da identidade portuguesa e da cozinha nacional.

10 O Estado Novo foi em Portugal um regime político autoritário de cunho nacionalista e corporativista, de inspiração fascista, liderado por António Oliveira Salazar e durou 41 anos, entre os anos de 1933 a 1974. 
Para compreender esses elementos que foram selecionados para representar o país oficialmente, Sobral (2007) retoma a história do país e da Europa para analisar o contexto do período e as dinâmicas desse movimento. Por meio da literatura e outras fontes históricas, o autor identifica a predominância do uso e apropriação da cozinha francesa na sociedade de corte portuguesa, desde os cardápios e serviços até os costumes apresentados nas festas e jantares oficiais.

Sobral (2007) faz um comparativo entre os menus oficiais do século XIX e os menus oferecidos no Festival de Santarém, em que ambos demonstram uma situação de contraste extremo com a exaltação do nacional e do regional. Os cardápios do século XIX evidenciavam as diferenças entre cozinha de rico e cozinha de pobre, assim, mais que a defesa de uma nacionalidade, esses cardápios abrigam uma manutenção dos status quo por meio da distinção social.

A cozinha francesa predominava nas classes dominantes portuguesas representativas de um processo civilizador, mas a cozinha regional era enaltecida em determinados eventos sociais para demarcar as especificidades do português por meio de seus hábitos alimentares. Aos ricos recomendava-se a cozinha internacional, aos pobres a cozinha nacional - composta pelos elementos regionais da classe rural trabalhadora.

José Sobral (2007) demonstra claramente que a cozinha nacional portuguesa fora designada como comida de rico e, por sua vez, a comida regional como comida de pobre. Esse é um dos principais aspectos que a formação das duas cozinhas se aproxima e se inter-relaciona. Como já apontado no início do capítulo, no Brasil acontece de modo muito semelhante, onde a cozinha regional brasileira é entendida como cozinhas populares, enquanto a nacional se relaciona com as influências das cozinhas internacionais, especialmente por meio dos finos restaurantes dos hotéis que eram frequentados pela burguesia brasileira. (DÓRIA, 2014; BELLUZZO, 2010)

No caso brasileiro, o sentimento nacionalista intensificou-se na sociedade principalmente no período da a regência do príncipe D. Pedro I, após D. João VI e sua corte deixar o país em 1821. O fim da monarquia e o início do império brasileiro e as lutas políticas de D. Pedro por uma constituição parece ter contribuído para o início da conscientização do Brasil enquanto Estado-nação, deixando de ser colônia para ser autônomo, ainda que no comando de um português. 
Assim, podemos entender que a Independência do Brasil seria o resultado de um processo anterior, já iniciado em 1822. "É em torno da figura de Pedro II que em muito se personificou a unidade do Estado Nacional, assim como a responsabilidade de introdução da modernidade no país, o projeto iluminista que integra o Brasil à cultura ocidental, ao mundo civilizado”. (DUTRA, 2004, p. 95)

Entretanto, segundo diversos historiadores, não houve participação popular nesse movimento e a legitimidade do novo regime político começa a ser viabilizada com a elite política dos grandes estados em ascensão São Paulo, Minas Gerais e Rio Grande do Sul -, instaurando-se a república oligárquica a partir do modelo federativo (DUTRA, 2004), que já vinha sendo reivindicado desde o império.

Tendo em vista que a constituição da nação enquanto uma instituição é relativamente nova no processo histórico da sociedade ocidental, datando pouco mais de duzentos anos, "[...] ela pressupõe a existência de cidadãos com direitos igualitários, de uma sociedade secularizada, com instituições independentes e desenvolvidas. No Brasil, como nos demais países da América Latina, em sua gênese, nação e modernidade caminham juntas”. (OLIVEN, 2002, p. 17)

No século XIX Machado de Assis já havia se ocupado da questão da nacionalidade na literatura brasileira. Em um ensaio publicado em 1837, embora reconhecesse a legitimidade de um 'instinto de nacionalidade' por parte da literatura da então jovem nação brasileira, ele argumentava que não se devia carregar no uso do local sob o risco de restringir a compreensão das obras a um grupo muito restrito. Para Machado, 'um poeta não é nacional só porque insere nos seus versos muitos nomes de flores ou aves do país, o que pode dar uma nacionalidade ao vocabulário e nada mais'. (OLIVEN, 2002, p. 20, grifo do autor)

Essa discussão sobre o que é ser brasileiro e a valorização da pátria é retomada de modo mais explícito na semana modernista de 1922, que representa a busca pela nacionalidade brasileira valorizando sua cultura, partindo da afirmação de brasilidade.

Oliven (2002) retoma os preceitos da Semana da Arte Moderna de 22 com o ideal nacionalista na busca pelo reconhecimento universal, contrapondo-os com o Manifesto Regionalista iniciado por Gilberto Freyre em 1926, que partia da valorização dos costumes e tradições regionais. 
No manifesto é possível encontrar a preocupação da manutenção das tradições, inclusive as culinárias, cujo autor afirmou: “[...] uma cozinha em crise significa uma civilização inteira em perigo, o perigo de descaracterizar-se”. (FREYRE, 1976, p. 76 apud OLIVEN, 2002, p. 28)

É neste período, entre guerras, que mudanças ocorrem e instigam novas reflexões sobre o país, que passava por uma consolidação política e enfrentava crises consequentes da quebra da bolsa de Nova York (1929) e, precedia a Segunda Guerra Mundial (1939). Neste momento, “o nacionalismo ganha ímpeto e o Estado se firma”. (OLIVEN, 2002, p. 31)

Desde a Independência do Brasil, passando pelos diferentes momentos históricos e as mudanças políticas, o pensamento social brasileiro é constituído de tais questões, ora enaltecendo o nacional, ora o regional, mas sempre com a perspectiva da construção e reconhecimento da nação e da construção da identidade brasileira.

Assumindo essas características torna-se mais evidente o processo de formação da cozinha brasileira que varia e privilegia ora os elementos nacionais ora os elementos regionais, dependendo dos interesses políticos e econômicos, bem como dos movimentos culturais e sociais do momento histórico em questão.

A alimentação como problema central da questão nacional está presente no Brasil pelo menos desde a Primeira República, em que se via a fome e a pobreza como um problema social. Já no século XX, após a Revolução de 1930 em que se constitui a Era Vargas, se tem um projeto político-pedagógico para a construção da nação pensando a nutrição no cenário mundial por meio da ciência. Josué de Castro aproxima-se do discurso sanitarista desenvolvimentista, em que reconhece a questão da fome como um problema de saúde pública.

O projeto civilizatório nacional configurado no modelo explicativo-causal e nas medidas saneadoras da fome e do atraso brasileiros, presentes nessas ideias veiculadas pelo INUB, teria por premissa uma reforma social orientada pela ciência e liderada pelo Estado, na qual progressismo, patriotismo e política alimentar convergiriam em um investimento no homem, para remoção dos obstáculos ao nation and state building erguendo a nacionalidade e redimindo-a do atrasa. E inscrevendo o Brasil na civilização não mais da comida bárbara, mas da alimentação pública. (BIZO; LIMA, 2010, p. 204-205, grifo do autor) 
Nesse ideal de nação, "de acordo com os autores, sendo a "subalimentação nacional" o principal e mais complexo problema do país, representaria um desvio aos dirigentes e requeria urgente solução”. (BIZO; LIMA, 2010, p. 198) Nesta máxima, superar a fome, superaria o barbarismo e elevaria a civilização da nação, uma vez que a fome traz subnutrição e com ela doenças, conflitos sociais, derrotas políticas e militares. A fome, portanto, afetaria a condição nacional como um país de fome, ou seja, uma sub nação.

Neste período o projeto nacional preocupa-se no reconhecimento do país por suas glórias e beneficies, eliminando-se problemas tidos como particulares de países de "terceiro mundo" e não desenvolvidos.

\section{CONSIDERAÇÕES FINAIS}

"O comportamento relativo à comida liga-se diretamente ao sentido de nós mesmos e à nossa identidade social, e isso parece valer para todos os seres humanos”. (MINTZ, 2001, p. 31) Os hábitos alimentares no Brasil passam por mudanças significativas após a instalação da corte portuguesa no Rio de Janeiro com a inserção de diferentes ingredientes e de novos modos de fazer e de comer. As transformações dos costumes à mesa, de socialização e do fluxo de portugueses e brasileiros, trazem transformações políticas e sociais importantes, assim como reflexões acerca das identidades coletivas de quem nasceu brasileiro e de quem escolheu o país como nova morada.

O final do século XVIII e início do XIX é muito representativo na construção de sentimentos relacionados à brasilidade e ao significado do que é ser brasileiro, que perpassam questões políticas e culturais entre Brasil e Portugal, indo além das questões internas, como por exemplo, do processo de independência do país.

As trocas simbólicas e materiais entre os dois países são dinâmicas importantes e chave de explicação para o entendimento da formação da nação brasileira.

A definição gradativa do território, a formação de uma mentalidade luso-brasileira e o sentimento de independência caracterizaram um sentido mais acentuado de nacionalidade do que o próprio processo de independência. Marcado por fatores externos relacionados à vida política europeia, o processo de independência, na realidade, pouco contribuiu para a construção do sentimento nacional. (OLIVEIRA, 1990, p. 77) 
Representantes do pensamento social desse período, como Eça de Queirós e Machado de Assis demonstraram por meio de seus artigos (científicos e de opinião) a formação de um sentimento e de um discurso nacional que apontavam para as particularidades de suas nações, que perpassavam por elementos e fenômenos desde o âmbito privado, dos hábitos e costumes cotidianos, até o âmbito público, das políticas públicas e normativas instauradas para consolidar seus projetos nacionais.

É fato que o período destacado neste artigo designado como Primeiro Império até a constituição da Primeira República, passando por todo o processo de Independência do Brasil é um dos momentos cruciais para a formação da identidade nacional, da demarcação de fronteiras, reconhecimento das diferenças culturais e, consequentemente, da formação do que se entende hoje por culinária ou cozinha brasileira.

Um período de efervescência política, econômica, social e cultural que demarca o processo civilizador do Brasil, da constituição do caráter nacional, dos marcadores sociais da diferença, dos status quo do país. Um momento em que as migrações se intensificaram e com isso as trocas materiais e imateriais que contribuíram para pensar ou "inventar" a brasilidade a partir da formação de identidade nacional, etnicidade e políticas de imigração. (LESSER, 2015)

Tratando especificamente da formação da cozinha brasileira temos nesse período o desenvolvimento de certas práticas que seguiram o fluxo do mundo do trabalho e das convenções sociais que se estabilizavam conforme o país crescia em número de habitantes e de estrangeiros que aqui se acomodavam. "O hábito de comer fora de casa foi imposto aos segmentos sociais de baixa renda devido ao horário de trabalho das casas comerciais, que encerrava seu expediente às 22 horas”. (BELLUZZO, 2010, p. 67)

Nesse sentido diferentes estabelecimentos começaram a surgir para suprir essa demanda. "Os portugueses ofereciam opções populares, como tavernas, botequins e casas de pasto, ${ }^{11}$ em geral frequentados por funcionários públicos, operários, caixeiros e pequenos comerciantes”. (BELLUZZO, 2010, p. 67)

11 Segundo Belluzzo (2010) as tavernas e botequins eram um tipo de armazém que vendiam bebidas alcoólicas, como vinho e cachaças e petiscos e comidas caseiras com preços acessíveis. Já as casas de pasto serviam dois tipos de refeições mais elaboradas e mais custosas: o prato de colher - constituídos de ensopados, guisados e angus - e o prato de garfo, com meu fixo e pratos mais leves e refinados acompanhados de meia garrafa de vinho. 
Além desses havia restaurantes mais sofisticados, mais comumente situados em hotéis recém estabelecidos no Brasil seguindo os moldes da gastronomia francesa e, portanto, da profissionalização das práticas de cozinha.

\begin{abstract}
Enquanto franceses e italianos predominavam nos restaurantes e confeitarias, a cozinha portuguesa permanecia nas tavernas, nos botequins e casas de pasto. Aí eram servidos caldos verdes, caldeirada de peixe, bife a cavalo, bacalhau à lagareira ou à moda do Porto, sardinhas, olla podrida (depois denominada 'cozido carioca') e galinha à cabidela. (BELLUZZO, 2010, p. 93 grifo do autor)
\end{abstract}

Mediante essa explanação e, seguindo os relatos históricos de Rosa Belluzzo (2010) percebemos que há dois movimentos em relação à culinária, primeiro o já discutido movimento regionalista que preza as especificidades das regiões ao que diz respeito aos hábitos alimentares, não só no uso de ingredientes, mas, também, nos modos de preparo, nas tradições regionais que foram sendo constituída a partir de uma culinária popular, do cotidiano; e em segundo, o movimento nacionalista, que busca uma universalidade no sistema alimentar do Brasil, caracterizando determinados pratos, como por exemplo, a tão discutida feijoada, ${ }^{12}$ como prato tipicamente nacional, que busca modos de fazer mais elaborados, sofisticados, que demandam técnicas e saberes profissionais, apontando para um processo civilizador do país, na qualificação profissional, na constituição de um habitus $^{13}$ (ELIAS, 2011) e costumes moldados a uma classe dominante do país, assumindo um discurso oficial.

Os dois movimentos - tanto no Brasil quanto em Portugal - contribuem para a compreensão da formação das cozinhas e das identidades nacionais, que se aproximam no modus operandi de se relacionar com a comida e desenvolver uma cultura alimentar ampla e complexa.

12 A feijoada enquanto prato típico brasileiro é discutida por diferentes autores que trazem diferentes perspectivas e historicidades em sua constituição. Para mais detalhes sugiro consultar as já presentes referências Belluzzo (2010) e Dória (2014) e, para aprofundar no assunto consultar o livro A vitória da feijoada de 2012 do historiador Almir Chaiban El-Kareh.

13 Utilizo aqui o conceito de habitus cunhado em 1933 por Norbert Elias em seu livro O processo civilizador, em que é compreendido como um aspecto consequente do processo civilizador da sociedade ocidental, cuja gênese está no que o autor chama de Sociedade de Corte, onde aspectos da vida individual e da social foram se moldando conforme ideias e práticas específicas de autocontrole e controle dos afetos que vão sendo elaborados, transformados e sofisticados em um longo processo histórico. 
No esforço aqui realizado de pensar acerca do tema das trocas culturais e materiais na alimentação entre Brasil e Portugal e suas contribuições para formação de identidades nacionais, podemos, ainda que de maneira superficial, indicar mais proximidades do que se mostra inicialmente entre as duas nações. Portugal tem o papel de civilizador no processo de desenvolvimento da nação brasileira, porém invertido ao longo dos entrelaçamentos culturais e políticos com o Brasil. Aponto isto não apenas no campo da alimentação, mas sobretudo, dos significados e representações de que cada ingrediente, prato e saberes trazem para o campo das identidades coletivas e de que maneira elas são impressas no cotidiano brasileiro e no discurso oficial a fim de legitimar o país enquanto Estado-nação.

\section{REFERÊNCIAS}

ABDALA JÚNIOR, B. Ecos do Brasil: Eça de Queirós, leituras brasileiras e portuguesas. São Paulo: SENAC São Paulo, 2000.

ANDERSON, B. Comunidades imaginadas: reflexões sobre a origem e a difusão do nacionalismo. São Paulo: Companhia das Letras, 2008.

ANDRADE, J. R. Gula e literatura: diálogo gastronômico com a obra de Eça de Queirós. Revista Desassossego, São Paulo, v. 7, n. 14, p. 204-2018, 2015. Disponível em: https://www.revistas.usp.br/desassossego/article/view/90834. Acesso em: 18 abr. 2017.

ASSIS, J. M. M. Memórias Póstumas de Brás Cubas. Rio de Janeiro: Editora Nova Aguilar, 1994.

BELLUZZO, R. Machado de Assis: relíquias culinárias. São Paulo: Ed. UNESP, 2010.

BIZO, M. L. G.; LIMA, N. T. O projeto civilizatório nacional do Instituto de Nutrição da Universidade do Brasil (1946-1960). Perspectivas, São Paulo, v. 37, p. 191-209, 2010. Disponível em: https://periodicos.fclar.unesp.br/perspectivas/article/ view/3558. Acesso em: 23 out 2017.

BRAGA, I. M. R. M. D. Sabores do Brasil em Portugal: descobrir e transformar novos alimentos (séculos XVI-XXI). São Paulo: Editora Senac São Paulo, 2010.

CANDIDO, A. Eça de Queirós, passado e presente. In: ABDALA JÚNIOR, B. Ecos do Brasil: Eça de Queirós, leituras brasileiras e portuguesas. São Paulo: SENAC São Paulo, 2000.

DAMATTA, R. O que faz o brasil, Brasil?. 5. ed. Rio de Janeiro: Rocco, 1991.

DÓRIA, C. A. Formação da culinária brasileira: escritos sobre a cozinha inzoneira.

São Paulo: Três Estrelas, 2014. 
DUTRA, R. C. A. Nação, região, cidadania: a construção das cozinhas regionais no Projeto Nacional Brasileiro. Campos, Curitiba, v. 5, n. 1, p. 93-110, 2004.

ELIAS, N. O processo civilizador. 2. ed. Rio de Janeiro: Zahar, 2011.

FANTINI, M. Recepção de Eça de Queirós por Machado de Assis. Letras, Santa Maria, v. 2, n. 45, p. 111-125, 2012. Disponível em: https://periodicos.ufsm.br/ letras/article/view/12209. Acesso em: 18 abr. 2017.

FREYRE, G. Ordem e Progresso. 6. ed. São Paulo: Global, 2010.

HALL, S. A identidade cultural na pós-modernidade. 9. ed. Rio de Janeiro: DP\&A, 2004

LESSER, J. A invenção da brasilidade: identidade nacional, etnicidade e políticas de imigração. São Paulo: Editora Unesp, 2015.

MAGALHÃES JÚNIOR, R. Vida e obra de Machado de Assis: aprendizado. São Paulo: Record, 2008.

MINÉ, E. Eça jornalista no Brasil. In: ABDALA JÚNIOR, B. Ecos do Brasil: Eça de Queirós, leituras brasileiras e portuguesas. São Paulo: SENAC São Paulo, 2000.

MINTZ, S. W. O poder do doce e a doçura do poder. In: MINTZ, S.; DABAT, C, R. (org.). O poder amargo do açúcar: produtores escravizados, consumidores proletarizados. Recife: Editora Universitária da UFPE, 2003. p. 171-193.

MINTZ, S. W. Comida e antropologia: uma breve revisão. Revista Brasileira de Ciências Sociais, São Paulo, v. 16, n. 47, p. 31-178, 2001. Disponível em: http:// www.scielo.br/pdf/rbcsoc/v16n47/7718.pdf. Acesso em: 28 out. 2011.

OLIVEIRA, L. L. A questão nacional na Primeira República. São Paulo: Brasiliense, 1990.

OLIVEN, R. G. Cultura brasileira e identidade nacional (o eterno retorno). In: MICELI, S. O que ler na ciência social brasileira. São Paulo: ANPOCS: Editora Sumaré, 2002. p. 15-43.

PEIRANO, M. G. S. Antropólogos e suas linhagens. Brasília, DF: UnB, 1990. (Série Antropologia). Disponível em: http://vsites.unb.br/ics/dan/Serie102empdf.pdf. Acesso em: 7 maio 2008.

SILVA, M. C. M. Eça de Queiroz e a cozinha burguesa: literatura e alimentação. 2012. Dissertação (Mestrado em Ciências Sociais) - Universidade Federal do Rio Grande do Norte, Natal, 2012.

SILVA, P. P. Farinha, feijão e carne-seca: um tripé culinário no Brasil colonial. 2. ed. São Paulo: SENAC São Paulo, 2005. 
SOBRAL, J. M. Nacionalismo, culinária e classe: a cozinha portuguesa da obscuridade à consagração (século XIX-XX). RURIS, Campinas, v. 1, n. 2, p. 13-52, 2007. Disponível em: https://www.ifch.unicamp.br/ojs/index.php/ruris/article/ view/651. Acesso em: 1 ago. 2018.

WEBER, J. H. Machado: do discurso romântico da nacionalidade à crítica radical da nção. Machado de Assis em linha, Rio de Janeiro. v. 6, n. 12, p. 32-45, 2013. Disponível em: http://www.scielo.br/scielo.php?script=sci_arttext\&pid=S19836821 $2013000200004 \& \operatorname{lng}=$ en\&nrm=iso\&tlng=pt. Acesso em: 12 out. 2018. 



\title{
DISCURSOS SOBRE O COMER DE UM GRUPO DE TRABALHADORES CÓDIGOS DE IDENTIFICAÇÃO DO SAUDÁVEL NAS PRÁTICAS DE ALIMENTAÇÃO ${ }^{1}$
}

\author{
NATHÁLIA CÉSAR NUNES \\ FABIANA BOM KRAEMER \\ SHIRLEY DONIZETE PRADO \\ MARIA CLÁUDIA VEIGA SOARES DE CARVALHO
}

\section{INTRODUÇÃO}

Neste trabalho, buscamos discutir algumas ideias sobre o saudável a partir de Pierre Bourdieu (1989) e entendendo poder simbólico como aquele que produz um efeito de mobilização na prática alimentar, determinada por uma crença legitimada nas palavras de quem a pronuncia, consideramos que concepções de alimentação saudável orientam o consumo alimentar. Tais ideias sobre o saudável, de modo invisível, habitam o senso comum, inclusive com a cumplicidade dos que não se dão conta de que estão sujeitos ao poder simbólico ou mesmo daqueles que negam seu exercício. Em

1 Este trabalho é oriundo da dissertação de mestrado intitulada Modos de comer: práticas alimentares de trabalhadores de uma empresa prestadora de serviços de alimentação, defendida por Nathália César Nunes, em julho de 2016, pela Universidade do Estado do Rio de Janeiro. 
outras palavras, os sujeitos orientam suas práticas alimentares, muitas vezes inconscientemente, pelos significados que constroem, atribuindo-os, de forma concreta, às refeições e naturalizando-os na cultura local segundo códigos de identificação socializados em forma de consensus.

Hoje, o alimento está fortemente pressionado pelo rigor científico que envolve uma expertise (COLLINS; EVANS, 2010) consolidada e em sinergia com interesses mercadológicos que impõem a importância do caráter nutritivo à comida. Mas, o que seria o nutritivo se não houvesse um consensus sobre esse significado? Desta forma, o comer é normatizado como nutrição e ganha o estatuto de atividade necessária, com a exigência de obedecer a fórmulas balanceadas de nutrientes em proporções adequadas. Consideramos, então, o entendimento global de que, segundo essa perspectiva e no seu limite, é a composição química o que importa; assim, o alimento assume, por um lado, o papel de nutrir acima de quaisquer outros benefícios, subordinando a distinção, o prazer, o desejo à normas cientificamente legitimadas e, por outro lado, a condição de produto em seus encantos e proveitos definidos no mercado.

Um ponto importante a ressaltar é a posição do alimento dentro de um paradigma já estabilizado. Para encontrar um ponto de equilíbrio entre paradoxos e conflitos no universo urbano acerca de ideias de alimentação saudável, é fundamental atentar para a polissemia construída em cada narrativa com suas especificidades do cotidiano em relação ao bem-estar, ao consumo, ao corpo e aos seus cuidados, além da distinção social ou da influência do meio na busca pela tríade juventude, saúde e beleza. São questões que se encontram enraizadas nas múltiplas formas e representações que circulam, construídas pela ênfase na maneira de ser e estar, bem como, nas tendências oscilantes e nas experiências dos sujeitos, que são movidos pelo dinamismo de estarem vivos e inseridos em seus grupos.

Além disso, uma das atribuições da atividade de pesquisa é a de estranhar verdades absolutas, desafiando o pensamento a compreender, na potência das palavras, o poder de construção da realidade que tende a estabelecer uma ordem. Se por um lado, o valor nutritivo é inerente à sua composição química do alimento, por outro, os significados desse valor são concebidos como capital simbólico com intensidades diferentes observadas na prática discursiva de acordo com os contextos e os agentes desses discursos. Se, por exemplo, o que se chama de alimento funcional assume um determinado 
significado, é porque também contrai um reconhecimento de ser "[...] todo aquele alimento ou ingrediente que, além das funções nutricionais básicas, quando consumido na dieta usual, produz efeitos metabólicos e/ou fisiológicos benéficos à saúde, devendo ser seguro para o consumo, sem supervisão médica [...]” com legitimação da Agência Nacional de Vigilância Sanitária (Anvisa). (BRASIL, 1999, p. 3) Neste caso, a noção de risco marca presença delimitando uma verdade definitiva que opera reforçando o aspecto preventivista da alimentação, reordenando a sensibilidade para a qualidade de vida, os significados dos alimentos, o gosto, o prazer, assim como, os elementos éticos, morais e culturais que interferem nos discursos, nas práticas e nos modos de vida dos trabalhadores.

Tendo Giddens (2002) por referência, consideramos que as escolhas dos sujeitos estão de acordo com o seu modo ou estilo de vida. Nessa esteira, o sujeito é o ator principal do consumo de alimentação e saúde, que se traduz em uma compreensão comum, constituindo-se como consumível em seu ambiente cultural repleto de significados e repercussões no corpo.

Os discursos que envolvem a alimentação em muito orientam a ordem de significados dos modos de vida, das pessoas e das coisas. Assim, conforme afirmam Contreras e Gracia-Arnaiz (2011), o trabalho, o lazer, o estudo, as comemorações, cada uma dessas situações tem sua própria expressão discursiva. A visão antropológica da alimentação mostra que ela sofre interferência de normas, crenças, regras, valores e significados que representam formas de pensar socialmente produzidas. Com esse olhar, enfatizamos que a alimentação não é influenciada exclusivamente por fatores econômicos, sofrendo também pressões de ordem cultural e ideológica, o que a torna fundamental nas relações sociais - neste nosso caso específico, dos trabalhadores das empresas que atuam no programa de governo intitulado Restaurante Cidadão.

$\mathrm{O}$ ato de comprar determinado alimento, sua forma de preparo, as crenças em suas propriedades funcionais e o modo de servir e comer aquele alimento são práticas que expressam sujeitos marcados por códigos de identidade. (GRACIA-ARNAIZ, 2005) As escolhas alimentares envolvem em seus discursos prestígio social e uma miríade de elementos de distinção. Desse modo, um universo de subjetividades convoca o olhar para o comer sob o crivo de dimensões social, política e cultural, enfatizando a relação do alimento com o corpo e com o cuidado de si para além das fronteiras dos nutrientes. Segundo Sahlins (2003) é impossível derivar o cultural 
diretamente da experiência ou do acontecimento, na medida em que o consumo alimentar se desdobra em um mundo já simbolizado. Assim, a experiência, mesmo quando se depara com uma realidade externa à linguagem, por meio da qual é compreendida, é construída como uma realidade humana por seu próprio conceito. As identidades culturais associadas à alimentação se constroem em ambientes privilegiados, onde os grupos sociais se distinguem, se reconhecem e se veem reconhecidos em seus discursos. (MACIEL, 2005) Esse ambiente privilegiado pode ser, por exemplo, um local de trabalho onde as pessoas mantêm relações sociais diárias e algumas esperam se destacar perante as outras.

A alimentação realizada em um local de trabalho, como os que abrigam o programa Restaurante Cidadão - voltado para a preparação de refeições ancoradas em normas biomédico-nutricionais e discursos que anunciam o oferecimento de alimentação saudável aos usuários -, pode ter um importante peso na vida das pessoas que aí desenvolvem suas atividades laborais. O ambiente de trabalho, deste modo, interessa-nos como campo de estudo, considerando que a redução do conceito de consumo alimentar à simples quantidade de nutrientes nos alimentos escapa à politização e ao ressignificado do comer para os trabalhadores. Daí a importância de escolhermos esse recorte da sociedade para uma aproximação às ideias que guardam em torno de suas práticas alimentares, deslocando o foco da associação entre má alimentação e risco de adoecimento e dirigindo-o aos discursos que expressam aspectos simbólicas da alimentação e à outro tipo de risco: o da alienação de trabalhadores aprisionados em suas crenças por falta de alternativas discursivas.

A partir de tais referenciais, buscamos compreender práticas alimentares dos trabalhadores de baixa renda familiar, a partir da desnaturalização de concepções sobre alimentação saudável em cenários simbólicos observados em distintas situações da vida perante a sociedade e considerando seus vínculos com a construção de códigos identitários.

\section{O CENÁRIO DO ESTUDO: SOBRE OS RESTAURANTES POPULARES OU RESTAURANTE CIDADÃO}

Recorremos à abordagem antropológica para conduzir o estudo ao ampliar o que se costuma denominar noção de pessoa, reconhecendo ser insuficiente 
situar-nos sobre o plano unicamente representacional. Este plano corresponde a apenas parte do fenômeno, em que representações e processos empíricos não constituem mais que dimensões ou expressões sempre articuladas das práticas humanas investigadas, lugar onde o físico, o psíquico e o social não mais podem ser distinguidos.

O cenário do estudo pode ser apresentado a partir de uma trajetória que tem início no Restaurante Popular Betinho, inaugurado no ano de 2000 e localizado nas proximidades da Estação Central do Brasil na cidade do Rio de Janeiro. Foi o primeiro de um conjunto que chegou a um total de 16 desses equipamentos sociais no estado do Rio de Janeiro, entre capital e interior. No ano de 2017, quase todas as unidades foram desativadas em função de restrições no pagamento por parte do Governo do Estado às empresas do ramo dos serviços de alimentação que ali atuavam. Alguns restaurantes foram municipalizados; destes, uma parcela deixou de funcionar e outros poucos permanecem ainda em atividade na Cidade Maravilhosa. ${ }^{2}$

Os Restaurantes Populares foram concebidos como espaços públicos destinados à produção e comercialização de refeições prontas como programa social do Governo do Estado do Rio de Janeiro estruturado através de contratos com empresas privadas especializadas e com apoio do Governo Federal. Vale ressaltar que o programa foi elaborado dentro da proposta de seguir os preceitos de uma alimentação saudável, ou seja, de oferecer uma alimentação balanceada, garantindo a variedade dos cardápios, com equilíbrio entre os nutrientes - proteínas, carboidratos, lipídios, minerais, vitaminas, fibras e água - na mesma refeição, possibilitando o máximo aproveitamento pelo organismo, reduzindo, assim, riscos à saúde. (BRASIL, 2004) Os termos contratuais entre as partes estabeleciam que a elaboração dos cardápios deveria ser orientada por parâmetros nutricionais - por exemplo, café da manhã com cerca $500 \mathrm{Kcal}$ e almoço em torno de $1.400 \mathrm{Kcal}$. Ademais, a produção das refeições, propriamente ditas, deveria obedecer a parâmetros e processos higiênico-sanitários seguros. As refeições deveriam ser comercializadas a preços acessíveis - café da manhã custando $R \$ 0,35$

2 A cidade do Rio de Janeiro ganhou o título de Cidade Maravilhosa, em 1904, devido a um registro, durante o carnaval, no jornal O Paiz, sendo o termo usado por jornalistas, escritores e poetas para se referir à cidade. Em 1935, André Filho compôs uma marchinha de carnaval de mesmo nome e a música se transformou no hino da cidade popularizando-se em todo o mundo. 
e almoço R\$ 1,00 para o usuário ${ }^{3}$ - a um público de trabalhadores formais e informais de baixa renda, desempregados, estudantes, aposentados, moradores de rua e famílias em situação de acentuada pobreza. De acordo com a Secretaria de Estado de Assistência Social e Direitos Humanos, esses serviços possibilitavam, muitas vezes, a única refeição do dia para muitas dessas pessoas. (SEASDH, 2010)

Nos jogos políticos, entre os altos e baixos dos governantes, o programa viveu - e ainda vive - suas ascensões e rebaixamentos. Essas oscilações incluem sua renomeação oficial para Restaurante Cidadão, embora esses lugares permaneçam no linguajar corrente no cotidiano carioca como restaurantes populares. Juntos forneciam uma média de 51.325 almoços por dia, de segunda a sexta-feira, das 10 às 15 horas; alguns, além do almoço, também forneciam cerca de 19.875 cafés da manhã das 6 às 9 horas. O cardápio do almoço era composto de sopa, três tipos de salada, prato principal (algum tipo de carne), opção ao prato principal (outro tipo de carne), guarnição (preparações à base de legumes), acompanhamento (arroz e feijão), sobremesa, que geralmente era uma fruta, e refresco industrializado de frutas. No município do Rio de Janeiro, eles estavam localizados nos bairros de Bangu, Bonsucesso, Campo Grande, Centro, Irajá, Jacarepaguá, Madureira e Méier. Hoje, apenas cinco estão em operação servindo no almoço arroz, feijão, carne, salada, sobremesa e uma bebida.

Esses restaurantes possuíam em média um quadro de funcionários composto por 50 pessoas e contavam, em geral, com os cargos de copeiro, ajudante de cozinha, cozinheiro, magarefe, estoquista, auxiliar de serviços gerais, operador de caixa, seguranças, assistente administrativo, nutricionista de planejamento e nutricionista chefe. Estudo realizado por Aguiar, Valente e Fonseca (2010), mostrou que os trabalhadores desses restaurantes eram, em sua maioria, do sexo masculino e com idade aproximada de 35 anos. Em termos de escolaridade, 42,2\% contavam com cinco a oito anos de estudo; $60 \%$ dos entrevistados recebiam até dois salários mínimos por mês. Em outro estudo com trabalhadores desses mesmos restaurantes, Falcão e demais autores (2012) chegaram a um perfil similar ao de $80 \%$ da

3 O governo complementava o valor das refeições ao seu custo final. Nos dias atuais, esses valores correspondem a $\mathrm{R} \$ 0,50$ e $\mathrm{R} \$ 2,00$, respectivamente e o complemento está a cargo da Prefeitura do Rio de Janeiro que mantém cinco restaurantes atendendo à população. 
população brasileira em relação a distribuição de renda, entre outras características populacionais apresentadas na Pesquisa de Orçamento Familiar (POF) de 2011.

Dentre esses restaurantes, à época do trabalho de campo, foi escolhido para este estudo o Restaurante Popular Getúlio Vargas, situado no bairro de Bangu, onde já havia inserção da equipe deste estudo, favorecendo a permanência em campo.

Em relação as técnicas da pesquisa qualitativa, optamos pela realização de entrevistas semiestruturadas realizadas individualmente em locais reservados dentro do próprio restaurante, gravadas, transcritas e, posteriormente, analisadas. Foram selecionados três temas-chave para a realização dessas conversas orientadas. Partimos de um modelo piloto de observação participante, considerando três visitações a esse local de trabalho: comidas feitas pelos trabalhadores em ocasiões especiais de comemoração, comidas consideradas saborosas e, por último, comidas consideradas saudáveis. A observação participante, aliada ao estado da arte problematizado a partir de revisão de literatura, balizou o cenário simbólico que delineou a análise dos discursos, uma vez que o analista é aquele que relaciona a linguagem ao mundo externo do sujeito.

Foram analisados discursos de dez trabalhadores entre homens e mulheres. Antes do início das entrevistas, foi fornecida uma breve explicação acerca dos objetivos da pesquisa e dos procedimentos metodológicos. ${ }^{4}$

A identidade que buscamos construir seguiu, nos termos de Stuart Hall (2014), uma concepção que não é fixa ou permanente, mas adaptativa às circunstâncias e aos contextos de vida dos trabalhadores, com significados que são naturalizados, reificados ou transformados a cada momento do processo cotidiano do comer e que geram interfaces com múltiplas questões permeadas pelas emoções dos sujeitos.

Segundo Orlandi (2010), o discurso é um efeito de sentidos produzidos entre aqueles que falam. Estejam eles se comunicando ou não, os efeitos são plurais e variados. Nosso intuito com essa metodologia é sistematizar

4 O projeto foi encaminhado ao Comitê de Ética em Pesquisa do Hospital Universitário Pedro Ernesto / Universidade do Estado do Rio de Janeiro e recebeu aprovação de acordo com o parecer consubstanciado do CEP, sob o $n^{\circ} 1.514 .655$. 
a relação entre as palavras e seus significados, entendendo que a produção de discursos implica uma ressignificação e um habitat de significados.

Uma análise de discurso envolve limites e mecanismos do processo de significação; não há um verdadeiro significado, mas, sim, aquele que produz sentido para os sujeitos do discurso. Dessa forma, é uma análise de códigos de identidade, de aproximações dos sujeitos com objetos simbólicos, fazendo enlaces que ecoam no contexto imediato dos trabalhadores do estudo. A compreenção de identidade opera como uma celebração móvel, “[...] formada e transformada continuamente em relação às formas pelas quais somos representados ou interpelados nos sistemas culturais que nos rodeiam”. (HALL, 2014, p. 14) Segundo essa perspectiva, o sujeito assume identidades diferentes em momentos distintos da sua vida. Para Woodward, Silva e Hall (2010, p. 53), “[...] diferentes contextos sociais fazem com que nos envolvamos em diferentes significados sociais [...] somos posicionados - e também posicionamos a nós mesmos - de acordo com os 'campos sociais' nos quais estamos atuando”. A cultura molda a identidade ao dar sentido à experiência e ao tornar possível optar, entre as várias identidades possíveis, por um modo específico de subjetividade. A globalização envolve uma interação entre fatores econômicos e culturais, causando mudanças nos padrões de produção e consumo, as quais produzem identidades novas e globalizadas. A promoção da homogeneidade cultural feita pelo mercado global pode levar ao distanciamento da identidade com relação à comunidade e à cultura local. Neste panorama, forma-se o grupo de consumidores globais, que podem ser encontrados em qualquer lugar do mundo e que mal se distinguem entre si. (DAMATTA, 1986)

É nesse cenário de globalização que são produzidas diferentes posições de identidade, gerando, o que Hall (2014) chama de crise de identidade, na qual novas possibilidades vão-se estabelecendo. A globalização é assim percebida como um processo de mudança que tem forte efeito sobre as identidades; o sujeito moderno não é mais um ser unificado como no passado, mas, sim, um sujeito fragmentado. Ou seja, a complexa vida moderna implica em que o sujeito assume identidades diferentes em distintos momentos e que podem, inclusive, entrar em conflito entre si. Dentro de nós há identidades contraditórias, empurrando em diferentes direções, de tal modo que nossas identificações estão sendo continuamente deslocadas. Estas transformações incluem a chamada descentralização do sujeito, 
quando abalam as próprias identidades pessoais. Este aspecto de transformação das identidades a partir dessa tensão entre "global e local” articula novas identificações aos sujeitos.

Neste estudo, o conceito de identidade, na perspectiva acima, fundamenta os discursos que expressam mudanças e permanências nas práticas alimentares no contexto sociocultural das unidades do Restaurante Popular.

\section{O QUE FAZ, OU NÃO, A ALIMENTAÇÃO DESSES NOSSOS TRABALHADORES A ALIMENTAÇÃO SAUDÁVEL DE TODOS?}

O discurso sobre alimentação saudável dos trabalhadores entrevistados está conectado com a história desses restaurantes no município do Rio de Janeiro, uma conexão que importa certas tendências do universo global, materializando-as em práticas cotidianas com modos variados. É o refinamento dessas variações nos discursos sobre o comer que nos interessa. $\mathrm{O}$ fio condutor que as aglutinou foi a certa alteridade entre casa e trabalho, uma vez que a trajetória histórica da constituição das unidades do Restaurante Popular foi baseada na implantação de políticas públicas de facilitação de alimentação saudável para a parcela mais empobrecida da sociedade. $\mathrm{O}$ ambiente de trabalho nesse caso é o lugar político de legitimação da alimentação saudável. Parafraseando Roberto Damatta (1986), se temos um universo nacional e suas variações, poderíamos nos perguntar: o que faz, ou não, a alimentação desses nossos trabalhadores a alimentação saudável de todos?

Para nós brasileiros, nem tudo que alimenta é sempre bom ou socialmente aceitável. Do mesmo modo, nem tudo que é alimento é comida. Alimento é tudo aquilo que pode ser ingerido para manter uma pessoa viva; comida é tudo que se come com prazer, de acordo com as regras mais sagradas de comunhão e comensalidade [...]. O alimento é algo universal e geral. Algo que diz respeito a todos os seres humanos: amigos ou inimigos, gente de perto ou de longe, da rua ou da casa [...]. Por outro lado, comida se refere a algo costumeiro e sadio, alguma coisa que ajuda a estabelecer uma identidade, definindo, por isso mesmo, um grupo, classe ou pessoa [...]. Temos então o alimento e temos comida. Comida não é apenas uma substância alimentar, mas é também um modo, um 
estilo e um jeito de alimentar-se [...]. A comida vale tanto para indicar uma operação universal - ato de alimentar-se - quanto para definir e marcar identidades pessoais e grupais, estilos regionais e nacionais de ser, fazer, estar e viver. (DAMATTA, 1986, p. 56)

O discurso sobre a comida caseira bem temperada marca uma proximidade com o núcleo familiar e seus consensus sobre o gosto, além de mostrar o quanto a construção de uma ideia de alimentação saudável interfere em nossas vidas, neste nosso estudo, apartando o "saudável do trabalho" da intimidade do lar. A comida da casa dos trabalhadores diferencia-se da alimentação saudável, tal como apresentada pelos organismos governamentais ligados ao campo da saúde em âmbito nacional e incorporada na comida do Restaurante Popular, fazendo a ponte entre uma e outra no próprio sujeito que alterna em sua prática alimentar a comida caseira e a comida produzida em larga escala. Nesse sentido, é relevante perceber como as práticas do comer estão associadas às representações cotidianas do que é saudável a cada momento. É o deslocamento do sentido e do significado daquilo que traz saúde, conforme o contexto em que o sujeito está inserido, subjetividades integradas à identidade de cada um. De acordo com Hall (2014), não importa quão diferentes seus membros possam ser em termos de classe, gênero ou etnia; uma cultura nacional busca unificá-los numa identidade cultural. Assim, é construída uma atmosfera onde todos se encontram representados como parte de uma mesma ordem do saudável, constituindo um vínculo de pertencimento a uma norma e divergindo dela, readaptando comidas no cotidiano de seus domicílios e em comemorações.

Ainda com base em Hall (2014), o sujeito assume identidades diferentes em diferentes momentos, identidades que não são unificadas ao redor de um eu coerente. Os trabalhadores brasileiros entrevistados, dessa forma, assumem gostos e preferências alimentares diferentes de acordo com a situação e o lugar onde fazem suas opções alimentares.

\section{SUBJETIVIDADES EM TORNO DE COMEMORAÇÕES, CARNES E FEIJOADA}

Quando a alimentação está associada a momentos de comemoração, as comidas consideradas "pesadas” e nada saudáveis para os parâmetros nutricionais, como por exemplo, feijoada, churrasco e peixe no coco, foram as 
preferidas pelos entrevistados. Elas se ressignificam com o deslocamento para um espaço que segue tradições familiares. Esses trabalhadores consideram que, numa situação de festa, deve-se pensar em agradar aos convidados e, portanto, compartilhar os gostos e preferências no que desejariam comer. Os costumes de servir certas comidas selam laços afetivos, culturais e sociais que reforçam os núcleos.

Partindo de observações que levam a representações que constroem a identidade alimentar de um grupo, muitos são os sentidos a serem interpretados em torno de um prato. Um exemplo típico é a feijoada. Segundo Siqueira e Siqueira (2013), o sabor do autêntico inserido na feijoada, como uma construção da identidade carioca, é emblemático, capaz de simbolizar um modo de ser aparentemente harmonioso - apesar das contradições que carrega. Como prato e como acontecimento, a feijoada constitui-se como um mito do nascimento do povo brasileiro. Pela importância de sua representação como bem cultural nacional, não é difícil entender o lugar de honra que ocupa à mesa quando é escolhida para sustentar, para ancorar, para dar chão a uma comemoração. Nesse espaço que ocupam na gastronomia, os atributos da feijoada extrapolam as fronteiras dos nutrientes e dos aspectos saudáveis e saborosos para se inscrever na memória social e ganhar sentidos e significados mais encorpados.

Subjetividades enredadas conduzem as interpretações dos discursos, tecidas também com as memórias afetivas que revelam as singularidades de cada sujeito. Para Carvalho, Luz e Prado (2011), o alimento que nutre desloca-se para além da condição de meros portadores de nutrientes, conferindo menos “objetividade” às experiências vividas e indo ao encontro do que se espera nas relações sociais, na cultura: a expressão de materialidades e de subjetividades que, em seus (des)acordos e relatividades, sustentam a vida.

Questões alimentares também permeiam o campo dos tabus, que podem ser específicos para cada grupo dentro do seu contexto social. Em 1978, Maués e Maués já observavam essas representações entre pescadores em uma comunidade amazônica, onde os alimentos impuros deviam ser afastados de pessoas impuras, pois poderiam agravar sua contaminação social e, consequentemente, seu estado de saúde. Como Woortmann (1978) observa, os padrões alimentares por um lado operam pela lógica da reprodução da força de trabalho e sobrevivência familiar, por outro lado agem pelo conhecimento e ideologias que otimizam a relação alimento/organismo. 
Referências ao prestígio podem ser encontradas em ocasiões especiais, associadas a comportamentos “extravagantes”. A maioria dos trabalhadores entrevistados respondeu que quando pensam em comida de festa relatam preparações caras, na maioria das vezes, destoantes de suas disponibilidades de compra. No entanto, a escolha por preparações, como a feijoada, que usa carnes variadas, ainda que possam ser adaptadas e modificadas em termos de concentração de carnes e feijão, é naturalizada com um glamour necessário às comemorações.

As festas são fonte de prazer e socialização com papel importante na comunicação de símbolos e códigos de distinção social para os trabalhadores. Reproduzem a fartura e reafirmam uma posição social com a escolha de um cardápio de prestígio social e que confere status ao anfitrião. O reforço de vínculos associados ao comer é sustentado pela proximidade e familiaridade nos discursos dos trabalhadores, dando segurança às relações afetivas e, em função de uma posição social no núcleo, reforçando uma posição de classe, como nas palavras de Pierre Bourdieu (2013, p. 31).

O senso de posicionamento que leva a abandonar objetos, lugares e práticas fora de moda ou, mais simplesmente, desvalorizados, para se voltar em direção a objetos sempre novos, por esta espécie de fuga para a frente, na dianteira, na vanguarda que define o esnobismo e que se aplica a todos os terrenos - ao esporte e à culinária, aos locais de férias e aos restaurantes -, orienta-se a partir de uma infinidade de indícios e diferentes indicações, desde as advertências propositais [...] até as evocações apenas conscientes que, a exemplo da experiência da divulgação ou do atravancamento, pendem insidiosamente para o horror ou aversão dos objetos ou práticas que se tornaram comuns.

A valorização da carne se reproduz nesse grupo como alimento forte, o que é legitimado por vários estudos. Segundo Marshall Sahlins (2003), a carne está marcada na sociedade americana com valor de fortaleza e sua inclusão corresponde a elemento central com o apoio periférico dos complementos (como arroz e legumes, por exemplo). A carne é a indicação de "força", evocando o polo masculino de um código sexual da comida. O historiador Henrique Carneiro (2003), em seu livro Comida e sociedade, destaca este aspecto que está inscrito no consumo da carne na sociedade ocidental. Aí, o consumo de carne é visto como um modelo de virilidade, 
associado não só à caça como atributo tipicamente masculino, mas também a uma noção de que o homem necessita de alimentos fortes e adequados ao seu papel na sociedade.

Retomando Woodward, Silva e Hall (2010), os sistemas de alimentação estão sujeitos às classificações do processo de ordenação simbólica, bem como, às distinções de gênero, idade e classe. Existem diferenças de classe social em nosso gosto pela comida. Ao trabalhar esta questão da comida e o seu prestígio, o exemplo da carne evidencia que, historicamente, seu consumo era restrito às elites e que entre os tipos de carne também há distinção. Sahlins (2003) explica que as carnes de porco e bovina, por exemplo, comunicam códigos distintos. A carne de porco tem menos prestígio que a carne bovina. A carne bovina é a comida de maior prestígio social, e consumida nas ocasiões mais importantes. Um assado de carne de porco não é tão solene como um corte de primeira de carne de boi, por exemplo.

Percebe-se que as lógicas que presidem as práticas alimentares desses trabalhadores trazem a marca da socialização, da cultura, do aprendizado e também são permeadas por um forte simbolismo, pelas identidades sociais, pelas condições materiais e pelas possibilidades de acesso aos diferentes alimentos. (CANESQUI, 1988)

\section{ARROZ COM FEIJÃO: O dE CASA É MAIS SABOROSO}

Contreras e Gracia-Arnaiz (2011) entendem que o status por meio do alimento pode se materializar não apenas em alimentos caros, mas também pela atitude de fazer preparações muito elaboradas que exigem tempo e técnica. Os trabalhadores produzem em casa comidas com uma culinária diferente daquelas produzidas nos restaurantes populares. A comida de todo dia apresentou-se como a que é considerada boa e saborosa. Referiam-se à comida caseira com status de bem temperada, comida básica (arroz com feijão e mistura, que seria a carne), feita por eles mesmos, mas livre da linha taylorita-fordista de produção, característica da organização do trabalho em restaurantes que produzem refeições em maior escala.

Os trabalhadores entendem que a comida que produzem nos restaurantes não é uma comida para ser saborosa. A produção nesses locais é sistematizada e executada em grande quantidade e, além disso, volta-se para um 
público de idosos e pessoas que possam ter alguma doença crônica, demandando uso de pouco sal e gordura. O sentido de racionamento de tempo no preparo identifica esta como uma "comida rápida”, que segue uma normatização de "comida sem risco de contaminação", que obedece a padrões nutricionais globais e que visam à saúde no seu sentido mais primário, ou seja, livre de doenças.

No cardápio dos restaurantes, o arroz e o feijão seguem traços de identidade nacional por serem consumidos diariamente, por milhões de brasileiros. No entanto, o arroz e o feijão preparados nesses restaurantes são diferentes daquele feito em casa: alimentação saudável no trabalho foi avaliada como uma comida sem graça, associada à falta de tempero. Nesse ponto, reiteramos, o estilo da "comida do trabalho" adapta-se ao conceito mais restrito de saúde para o corpo biológico. Compreendemos que o tempero é significado como elemento de intimidade nas práticas alimentares, nas culinárias de casa e assume no discurso um papel relevante, o que Garabuau-Moussaoui e Halpern (2004) denomina formação da identidade.

No que se refere à comida considerada saudável, os entrevistados quando questionados foram unânimes em suas respostas: comida sem sal, sem gosto, sem tempero, como, por exemplo, a comida servida no local do trabalho o Restaurante Popular. Uma visão reducionista que impacta diretamente na intenção do bom funcionamento do corpo, aquém do que o aspecto do saudável pode compor.

Nessa lógica, a alimentação saudável incorpora a representação do paradigma biológico hegemônico na concepção da Nutrição, reduzindo o alimento aos seus aspectos funcionais para prevenir que os indivíduos fiquem doentes ou para evitar o agravamento de doenças que os acometem. Ao mesmo tempo, é importante ter em conta que esse empreendimento é marcado por uma operação que visa render lucros máximos às empresas prestadoras de serviços de alimentação, o que, certamente, significa restrições nos custos na produção da comida ali elaborada. Há ainda que ter-se em conta os sentidos e significados atribuídos por muitos aos grupos sociais que fazem uso desses restaurantes, grupos que incluem os que são percebidos como a miséria da sociedade: desempregados, moradores de rua, prostitutas, usuários de drogas, entre outros; servida para essas pessoas, aquela comida dos restaurantes populares, qualquer que seja... por aquele preço... estaria boa, até demais... (KRAEMER et al., 2015) 
Por esses meandros e frente aos interesses políticos dos governos, aos objetivos lucrativos das empresas, aos valores atribuídos aos comensais desses restaurantes populares, a sensação de prazer e o papel do sabor da comida para satisfação pelo gosto são simplesmente deixados em segundo plano, perdendo sua importância em nome também dos valores nutricionais dos alimentos. Esse é um exemplo que reafirma o pensamento biomédico centrado nas necessidades humanas limitadas ao preestabelecido pela Biologia e em cenários socioculturais específicos. Por outra via, é fundamental considerar a perspectiva de que, para empreender discussões e ações em torno da alimentação, a composição nutricional dos alimentos e seus aspectos simbólicos são relevantes, como são também importantes, as limitações dimensionadas por questões financeiras em que o padrão alimentar remete à sobrevivência familiar. (CANESQUI, 1988)

Estas questões revelam diferentes sentidos que os sujeitos estabelecem com a alimentação e suas influências culturais e ideológicas. A comida é capaz de identificar e de ser identificada, sendo, em certas ocasiões, a própria definição da festa ou da comida do dia a dia de uma pessoa.

\section{CONSIDERAÇÕES FINAIS}

Dentro do propósito de compreender práticas alimentares dos trabalhadores de baixa renda familiar, a partir da desnaturalização das concepções sobre alimentação saudável, consideramos cenários simbólicos, observados em distintas situações da vida perante a sociedade, tendo em conta seus vínculos com a construção de códigos identitários.

Deparamo-nos com aspectos pertinentes às relações com o comer, conflitos cotidianos desta interação como às questões de identidade e subjetividades e, também, a busca pela saúde em seu contexto mais amplo, que abarca um universo simbólico de sentidos e significados, repercutindo, direta e indiretamente, nos corpos dos sujeitos. A alimentação consubstancia-se pautada nas condições de vida e do trabalho, do corpo posicionado dentro de um grupo social e dos parâmetros alimentares construídos através de identidades sociais.

O saudável na alimentação aparece além da tradução do que está normatizado nas políticas públicas de saúde e que vem sendo disseminado como técnica preventiva - e que espraia como preventivista - de doenças. Usamos 
uma lente apta a enxergar sem a restrição que a predominância do olhar biomédico impõe, ou seja, sem a restrição da prevenção, do tratamento e da cura. O conceito amplo de alimentação saudável permite uma reflexão mais crítica, visto que é um fenômeno social e comunicacional que, ancorado nas sensibilidades, afetos e subjetividades dos sujeitos, confere significados às experiências, aos lugares e aos corpos.

Assim, constatamos que a alimentação não é influenciada exclusivamente por fatores econômicos; ela sofre e reflete diversas pressões culturais, sociais e ideológicas, que são expressas pelos diferentes grupos. Marca as múltiplas e híbridas identidades de cada agrupamento e de cada indivíduo, de acordo com o contexto em que estão inseridos. O cotidiano urbano é permeado por uma farta diversidade de estímulos capazes de instituir conflitos nas práticas alimentares que envolvem o prazer, o comer saudável, o prestígio, o status, a tradição, os laços afetivos, entre tantos ingredientes que compõem um prato.

Por isso, é fundamental considerarmos pressupostos da alimentação que destaquem com igual importância os nutrientes dos alimentos e os valores simbólicos da comida. Dessa forma, evidencia-se o encontro do Ser Humano, na Cultura e no Desejo, com o alimento, na Natureza, atentos a que, em cada contexto, está presente uma infinidade de elementos influenciadores e influenciados, estruturados e estruturantes, contingentes e contingenciadores. Como descreve Carneiro (2003), o que se come é tão importante quanto quando se come, onde se come, como se come e com quem se come. A partir desta análise, é possível não apenas notar que os indivíduos buscam atender suas necessidades orgânicas e/ou emocionais a cada refeição, mas também identificar uma multiplicidade de sentidos e significados a cada escolha alimentar que é feita pelos trabalhadores analisados neste estudo.

\section{REFERÊNCIAS}

AGUIAR, O. B.; VALENTE, J. G.; FONSECA, M. J. M. Descrição sócio-demográfica, laboral e de saúde dos trabalhadores do setor de serviços de alimentação dos restaurantes populares do Estado do Rio de Janeiro. Revista de Nutrição, Campinas, v. 23, n. 6, p. 969-982, 2010. 
BRASIL. Agência Nacional de Vigilância Sanitária. Resolução $n^{0} 18$, de 30 de abril de 1999. Aprova o Regulamento Técnico que estabelece as diretrizes básicas para análise e comprovação de propriedades funcionais e ou de saúde alegadas em rotulagem de alimentos, constante do anexo desta portaria. Diário Oficial da União: seção 1, Brasília, DF, 3 maio 1999.

BRASIL. Ministério de Desenvolvimento Social e Combate à Fome. Manual Programa Restaurante Popular. Brasília, DF: Ministério de Desenvolvimento Social, 2004.

BOURDIEU, P. A Distinção: crítica social do julgamento. Porto Alegre: Zouk, 2013. BOURDIEU, P. O poder simbólico. Lisboa: Difel, 1989.

CANESQUI, A. M. Antropologia e alimentação. Revista de Saúde Pública, São Paulo, v. 22, n. 3, p. 207-216, 1988.

CARNEIRO, H. Comida e sociedade: uma história da alimentação. Rio de Janeiro: Elsevier, 2003.

CARVALHO, M. C. V. S.; LUZ, M. T.; PRADO, S. D. Comer, alimentar e nutrir: categorias analíticas instrumentais no campo da pesquisa científica. Ciência e Saúde Coletiva, Rio de Janeiro, v. 16, n. 1, p. 155-163, 2011.

COLLINS, H.; EVANS, R. Repensando a Expertise. Belo Horizonte: Fabrefactum, 2010 .

CONTRERAS, J.; GRACIA-ARNAIZ, M. Alimentação, sociedade e cultura. Rio de Janeiro: Editora Fiocruz, 2011.

DAMATTA, R. O que faz o brasil, Brasil?. Rio de Janeiro: Rocco, 1986.

FALCÃO, A. C. M. L.; PADRÃO, S. M.; KRAEMER, F. B. et al. Guia alimentar para população brasileira: adesão dos trabalhadores de restaurantes de coletividade no município do Rio de Janeiro. In: WORLD NUTRITION RIO 2012, 1., 2012, Rio de Janeiro. Anais [...]. Rio de Janeiro: Rio NW 2012: Universidade Estadual do Rio de Janeiro, 2012. p. 27-30.

FERREIRA, V. A.; MAGALHÃES, R. Práticas alimentares cotidianas de mulheres obesas moradoras da Favela da Rocinha. Ciência e Saúde Coletiva, Rio de Janeiro, v. 16, n. 6, p. 2983-2991, 2011.

GARABUAU-MOUSSAOUI, I.; HALPERN, C. Comment se transmettent les pratiques alimentaires. Sciences Humaines, Auxerre, n. 45, p. 74-76, 2004.

GIDDENS, A. Modernidade e Identidade. Rio de Janeiro: Zahar, 2002.

GRACIA-ARNAIZ, M. Em direção a uma Nova Ordem Alimentar?. In: CANESQUI, A. M.; GARCIA, R. W. D. (org.). Antropologia e nutrição: um diálogo possível. Rio de Janeiro: Fundação Oswaldo Cruz, 2005. p. 147-164.

HALL, S. A identidade cultural na pós-modernidade. Rio de Janeiro: Lamparina, 2014. 
IBGE. Análise do consumo alimentar pessoal no Brasil: POF 2008/2009. Rio de Janeiro: IBGE, 2011.

IBGE. Censo Demográfico 2010: características da população e dos domicílios: resultados do universo. Rio de Janeiro: IBGE, 2011.

KRAEMER, F. B.; GRACIA-ARNAIZ, M.; PRADO, S. D. et al. A comida para o alívio do sofrimento social: restaurantes populares no Brasil e comedores sociales na Espanha. In: PRADO, S. D.; KRAEMER, F. B.; SEIXAS, C. M. et al. (org.). Alimentação e consumo de tecnologias. Curitiba: CRV, 2015. p. 49-55. (Série Sabor Metrópole, v. 4).

MACIEL, M. E. Identidade cultural e alimentação. In: CANESQUI, A. M.; GARCIA, R. W. D. (org.). Antropologia e nutrição: um diálogo possível. Rio de Janeiro: Fundação Oswaldo Cruz, 2005. p. 49-55.

MAUÉS, H. R.; MAUÉS, A. G. O modelo da "Reima”: representações alimentares em uma comunidade amazônica. Anuário Antropológico, Brasília, DF, n. 77, p. 120-146, 1978.

ORLANDI, E. P. Análise de discurso: princípios e procedimentos. Campinas: Pontes editores, 2010.

SAHLINS, M. Cultura e razão prática. Rio de Janeiro: Zahar, 2003.

SEASDH. Secretaria do Estado de Assistência Social e Direitos Humanos. Restaurante Popular. SEASDH, Brasília, DF, 2010. Disponível em: http://200.156.42.162/webpopular/. Acesso em: 20 maio 2010.

SIQUEIRA, E. D.; SIQUEIRA, D. C. O. O sabor do autêntico: a feijoada na construção da identidade carioca. In: PRADO, S. D.; FREITAS, R. F.; FERREIRA, F. R. et al. (org.). Alimentação, consumo e cultura. Curitiba: CRV, 2013. p. 31-47.

WOODWARD, K.; SILVA, T. T.; HALL, S. Identidade e diferença: a perspectiva dos estudos culturais. Petrópolis: Vozes, 2010.

WOORTMANN, K. Hábitos e ideologias alimentares em grupos de baixa renda: relatório final. Brasília, DF, 1978. Relatório Final. 


\section{BREVES CONSIDERAÇÕES SOBRE GASTROPOLITICA}

EWERTON REUBENS COELHO-COSTA

\section{INTRODUÇÃO}

A alimentação, indispensável à vida, permite uma infinita troca de relações. A existência de culturas alimentares e de uma cadeia produtiva com atores, técnicas e receituário nos leva a compreender o papel da comensalidade em integrar e compartilhar momentos, experiências, para além da comida em si. Isso sustenta parte da teoria que sugere que a alimentação também implica na troca de relações, em tecnologia, em mercado e relações de desigualdade, como a falta ou a abundância de comida (APPADURAI, 1981), e possibilita a compreensão do conceito de gastropolítica, que coloca a comida num campo conflituoso de disputa de poder, revelando o papel político da alimentação, um campo com diferentes práticas, assimetrias, inclusões e exclusões e, apesar dos conflitos, encontra-se em autoconstrução.

Considerando a alimentação como um campo conflituoso, pode-se afirmar que as desigualdades alimentares fazem surgir mais especuladores e comerciantes do que alteração em fatores climáticos e físicos. A crise alimentar de 2007/2008 serve como exemplo para a premissa anterior, pois configurou-se como uma crise na produção de estoques mundiais de alimentos, que aumentou consideravelmente os preços e obrigou países a 
restringirem consumo, subsídios e exportações de bens como meio para solucionar o problema.

Dentre as causas que fazem eclodir esse tipo de crise estão a carência de produtos agroalimentares e minerais essenciais para a alimentação como: cereais, grãos, carnes, laticínios, dentre outros; importantes fontes nutricionais e de energia para a população e de outros tipos de alimentos que servem como matéria-prima para a produção de mercadorias da indústria alimentícia, que são afetadas diretamente por fatores como o alto preço do petróleo, que eleva o preço de insumos agrícolas. Há, também, outras causas como: o uso de grandes áreas cultiváveis destinadas a monoculturas para produção de biocombustíveis - como o milho usado para produção de etanol; o aumento do consumo de alimentos por diversas classes econômicas em países com grandes populações como Brasil, China e Índia; os impactos naturais ocasionados pelas mudanças climáticas - trazendo desequilíbrio nos períodos chuvosos e de estiagem, causando desertificações, alagamentos; a venda de commodities agroalimentares antes mesmo de eles serem produzidos; a existência de barreiras comerciais entre blocos econômicos ou países com produtividades variadas; e a inconstância de valorização de moeda interna baseada em moedas de grandes importadores de alimentos externos. Esses elementos, agindo em conjunto, acarretam inflações altas, aumentam os conflitos sociais, a miséria, a fome, o aumento de subnutridos e intensificam as consequências da crise.

As soluções para conter a crise favoreceram apenas empresas e países que já se destacavam no cenário agrícola e que não enfrentavam estragos ecológicos, nem desigualdades alimentares. Tais soluções esqueceram que o direito à alimentação adequada é garantido pela Declaração Universal dos Direitos Humanos (no artigo 25) e pelo Pacto Internacional de Direitos Econômicos, Sociais e Culturais (no artigo 11), desde dezembro de 1966, e que têm complementação com as Diretrizes Voluntárias em Apoio à Realização Progressiva do Direito à Alimentação Adequada no Contexto da Segurança Alimentar e Nutricional, que rege Estados membros do Conselho Geral da Organização das Nações Unidas para Alimentação e Agricultura (FAO), desde 2004.

Farid Benhammou (2009) já argumentava que as tensões alimentares e(ou) agroalimentares são seguidas por neocolonialismo agrícola e ecológico. Agrícola, porque as áreas cultivadas mudam de proprietários de terras sem 
levar em conta o que vem por trás dessas transações, como também mudam o uso da agricultura de subsistência para agricultura comercial. Ecológico, porque há mais cobiça por espaços naturais frágeis.

O contexto brasileiro serve bem para exemplificar esse pensamento, pois agricultores do Norte do país são podados da floresta amazônica por mecanismos, inclusive, com apoio governamental que permitem substituir a produção de pequenos produtores por grandes fazendas de soja e(ou) de arroz e criação de gado. $\mathrm{O}$ aumento da fabricação e agrocombustíveis faz com que a cana-de-açúcar seja preterida entre outras culturas e essas monoculturas acabam desequilibrando não só o ambiente natural, mas o alimentar, modificando e(ou) destruindo ecossistemas como floresta tropical e cerrado que já estão em declínio acelerado no Brasil (THÉRY, 2009), deixando de produzir culturas diversas em favor de monoculturas demandadas pelo capitalismo desenfreado.

A apropriação de terras por atores estrangeiros é outro fator que merece ser ressaltado, e ocorre a partir de duas premissas: terras são adquiridas em países do terceiro mundo para garantir a segurança alimentar de países ricos, mas dependentes como os do Golfo Pérsico e a China; terras cultiváveis tornam-se ativos financeiros estratégicos por serem baratas, enquanto o preço dos alimentos podem ter altas constantes - como o exemplo de coreanos e japoneses que adquirem terras no Brasil, Extremo Oriente Russo, Sudeste Asiático e na África, desenvolvendo ações que não garantem segurança alimentar para o país onde adquirem terras. (BENHAMMOU, 2009) E quando não encontram terras disponíveis, passam para a área de pesca, criando viveiros e fazendas aquáticas com criações específicas. Este fato fez com que Philippe Cury e Yves Miserey (2008) alertassem para o oceano transformado em "deserto líquido", e observar que pescadores locais não conseguem sobreviver sendo saqueados por uma indústria pesqueira externa. Assim, aqui pretende-se identificar estratégias que sustentam o papel político dos alimentos e como ações de gastropolítica se configuram.

\section{BREVE CONTEXTUALIZAÇÃO SOBRE ESTUDOS DE POLÍTICA COM FOCO NA ALIMENTAÇÃO}

O entendimento político da alimentação surge com estudos etnográficos inicialmente voltados para refletir sobre os direitos e os deveres sobre a 
alimentação, sobre a fome, sobre a dificuldade de acesso e a desigualdade de distribuição de comida e, em alguns casos, sobre a influência dos gêneros empregados a esses contextos.

A década de 1980 aparece como período de destaque na incidência de estudos voltados para analisar culturas alimentares, cozinhas e hábitos alimentares, a partir de práticas e relações de espectro político. Esse aumento de "interesse" por temas ligados à alimentação e áreas afins fez surgir, nas últimas quatro décadas, uma variedade de abordagens, como se pode encontrar em Goody (1982), que observa a distribuição do poder e a estratificação social de classes a partir de práticas alimentares; Mintz (1985), que trata de capitalismo usando o panorama do surgimento, produção e consumo do açúcar; Counihan e Kaplan (1998), que apresentam as relações entre comida e gênero; Yount-André (2018), que demonstra as dificuldades alimentares pelo prisma da migração e colonização. Inclui-se, também, Forson e Counihan (2012), que destacam a politização da comida na luta por uma mundo mais justo; Bestor (2001), considera a comida como importante fonte de economia e cultura do mundo globalizado; Caldwell (2002), que apresenta a comida como meio estratégico pra evitar colapsos da sociedade; e Gerhard (2015), que analisa o poder de políticas alimentares e raciais como meio para causar genocídio e guerras - com destaque para a política de fome criada pelos nazistas.

Outra característica sobre os estudos que envolvem política e alimentação é a existência de duas frentes significativas. Uma, que traz os militantes da alimentação discutindo politicas alimentares e a outra, caracterizada pela democratização da comida, do engajamento social frente à existência de políticas de assistência com alimentação para necessitados.

Outro elemento que agrega importância no panorama da politização das culturas alimentares e das cozinhas é o surgimento de movimentos ativistas, que, preocupados com a homogeneização da cultura, da comida e do comer, passaram a ter destaque no cenário mundial, como é o caso do movimento Slow Food.

A preocupação com o consumo e a qualidade de alimentos fez surgir pesquisadores e outros interessados em desenvolver sistemas alimentares alternativos (LE VELLY, 2017), que tivessem compromisso de sustentabilidade, usando agroecologia nos lugares de produção, de onde se observa ações como o retorno ao consumo de alimentos orgânicos, a criação de 
partidos "verdes" - surgidos simultaneamente como instituição política na Tasmânia (Austrália) e na Nova Zelândia, em 1972, migrando de lá para Europa e chegando no Brasil em 1982, tendo como articuladores inicias intelectuais, artistas e ativistas brasileiros em defesa do meio ambiente, que reivindicavam medidas para proteção do meio ambiente e uma nova conscientização social e moral sobre o consumo e os valores que levassem à sustentabilidade e ao bem-estar (HISTÓRIA..., 2012) -, e a existência do vegetarianismo - com todos os seus espectros (ovolactovegetarianismo, lactovegetarianismo, ovovegetarianismo, vegetarianismo semiestrito, vegetarianismo estrito) em resistência ao sistema caótico do consumo de alimentos -, e dos circuitos curtos agroalimentares (CCA) que valendo-se da proximidade geográfica e da relação produtor/consumidor, se configura como modo de se comercializar agroalimentos a partir da venda direta do produtor para o consumidor ou por um único atravessador (venda indireta), fortalecendo a produção e a identificação de produtos locais levando em conta sazonalidades e transformação de matérias primas locais. Essa politização da comida converge diretamente para o que se entende por democracia alimentar.

Essa democracia de pensar o fato alimentar seria uma resposta para analisar as transformações, consumo e valores que envolvem a alimentação frente à globalização que fez notar a vulnerabilidade do sistema alimentar e da produção de alimentos nos tempos atuais, criando tensões sociais e culturais complexas e que necessitam de intervenção política para mediar conflitos e pensar no que se pretende como futuro para as sociedades. Por isso, compreender as conjunturas sociopolíticas e econômica e contextualizar o momento histórico no qual foram construídas também é fundamental para compreender a necessidade da politização da comida.

\section{COMIDA, SOCIEDADE, CIÊNCIA E ATIVISMO}

Considerando que alimentação, identidade e política são elementos sempre presentes nas relações sociais, observa-se uma maneira complexa de interação entre elas desde tempos antigos. Foi a comida, aliás, a responsável por apresentar formas de estrutura e organização social, manter ativas as fronteiras sociais entre castas e classes sociais (APPADURAI, 1981; BOURDIEU, 1979) e raças e etnias (GOODY, 1982), e ser fundamental nas discussões 
de identidades (nacional, regional) e na formação de ideias para o futuro (sustentabilidade, agroecologia, novos sistemas alimentares etc.).

Em alguns casos, a culinária se funde à ideia de Nação, como é o caso da França, México e Peru, países consolidados pelo aspecto culinário e que se destacam por suas ações abrangentes em função de suas cozinhas, de sua identidade gastronômica. Dentre os elementos de desenvolvimento dessas nações, guardados como joias em arquivos nacionais e em bibliotecas importantes, ao mesmo tempo em que podem ser encontrados em uso, presentes nos livros de receita, textos sobre cozinhas, tratados sobre alimentação de forma variada - e isso demostra o respeito e a significância da comida para o crescimento e desenvolvimento desses países. E, para além disso, graças ao poder dos meios de comunicação e das interações entre nações, que encurtaram as fronteiras geográficas para tornar o conhecimento sobre gastronomia e culinária como algo dinâmico e capaz de gerar um mercado global econômico, político e cultural onde culturas alimentares aparecem como vetor de identidade, mas também como elementos de negociações, contestações, conflitos.

Ressalta-se que se pode observar governos como atores responsáveis em aumentar seu poder de interação com outra nação a partir de negociações políticas que envolvam a cultura alimentar - em muitos dos casos em que isso pode ser analisado, os governos desenvolvem ideologias para utilizar a diferenciação de suas cozinhas, de suas culturas alimentares e elaboram estratégias para aumentar seu poder de influência, a partir delas e gerar competitividade econômica, a partir de elementos cultuais ligados à gastronomia, à cozinha, à cultura alimentar. Esse entendimento vai de encontro à ideia de governamentalidade de Foucault, que reposiciona relações de poder para além do uso convencional jurídico ou bélico (contratos, guerras, conquistas de territórios).

Deste modo, pode-se considerar as culturas alimentares, a gastronomia, as cozinhas, os bens especiais agroalimentares e os produtos com apelação de origem (indicações geográficas) como recurso local e ativo global. (ÁLVAREZ, 2008; COELHO-COSTA, 2015, 2014) De posse desta compreensão, alguns países se destacam como verdadeiros "complexos gastropolíticos”, como é o caso do Peru - que a partir de uma reconciliação racial e sustentado por um projeto político, econômico e cultural transformou o país numa Meca gastronômica, tendo a culinária peruana como vetor de 
desenvolvimento nacional (MATTA; GARCÍA, 2019); do Japão - difundindo sua culinária tradicional como uma prática alimentar saudável e singular (HIROKO, 2008); da Turquia - que na tentativa de se aproximar da União Europeia, uniu forças do setor público com instituições privadas para modernizar sua cozinha e ganhar adeptos (KARAOSMANOĞLU, 2007), e de outros países, que integram ações e priorizam relações para explorar suas "cozinhas patrimoniais" (COELHO-COSTA; SANTOS, 2015), usando comida e cultura para aumentar seu poder, seu status, e criar novas possibilidades para atrativos, competitividades e desenvolvimento no disputado mercado global.

Desde o surgimento nas ciências sociais, ainda no século XIX até a década de 1960, pode-se observar pesquisadores e cientistas sociais analisando o fato alimentar no aspecto comportamental e sensorial, reconstruindo identidades sociais; é quando se observa a aplicabilidade da sociologia e antropologia da alimentação, a relação da alimentação com outros fenômenos sociais. (POULAIN, 2002) Mas, sabe-se que, até 1980, comida, alimentação, gastronomia, culinária não eram considerados temas relevantes para a antropologia (MINTZ, 2006), fato que muda com a explosão do mercado mundial de alimentos na década de 1990 e arregala os olhares de pesquisadores pelo mundo que passam também a tratar da alimentação em seus estudos.

Nas últimas quatro décadas, a comida tem motivado pesquisas cientificas e ações em prol da valorização da identidade gastronômica de sociedades, da sustentabilidade e da natureza. Nesse sentido, observa-se a existência do ativismo alimentar como um movimento social e político bastante importante nas discussões sobre alimentação.

Rudy (2012) apresenta as origens do ativismo alimentar ainda na década de 1960 como manifestações contra consumismos e usos inadequados de recursos naturais e para levar noções de sociedade local para âmbitos políticos internacionais, principalmente lutando contra algo que prejudicasse essas mesmas sociedades, privilegiando a rua como espaço de manifestação e usando meios de comunicar valores diferentes, protestar e apoiar minorias. Mas recentemente a internet ajudou a potencializar a visibilidade do ativismo alimentar e facilitar o acesso de mais pessoas aos conteúdos defendidos. (MACHADO, 2007)

Desse modo, o ativismo alimentar surge como uma forma de discutir as diferentes facetas da alimentação como a agricultura e sustentabilidade, 
soberania alimentar, segurança alimentar e nutricional, novos sistemas de produção alimentar, consumo consciente, novos hábitos alimentares, dentre outros.

Em cada uma dessas facetas observa-se a ligação da sociedade com a alimentação, a complexidade de relações - sociais, políticas, econômicas, culturais - e a necessidade de políticas direcionadas para a melhoria de cada uma delas, além de trazer melhoria de vida e bem-estar para a comunidade local, preservar práticas tradicionais, gerar desenvolvimento social e econômico. Afora a possibilidade de observar as transformações que a sociedade percorre também no aspecto alimentar, modificando sistemas alimentares e os gostos.

Em decorrência dessas transformações, o ativismo alimentar também constrói suas articulações como respostas críticas a modelos alimentares não salutares (como o fast-food); modelos de produção e consumo de alimentos que são pensados apenas para "mercados de singularidade", nos quais se observam políticas individualizadas para (re)valorizar atributos estéticos adjetivando comida como gourmet, artesanal, caseira, ético etc.; monoculturas que viram commodities (milho, soja, cana-de-açúcar). Ainda alavancam a discussão de padronização de mercado e de alimentos transgênicos; aos modelos de certificação e identificação de alimentos (indicação geográfica, comércio justo, orgânico) e o papel das comunidades tradicionais nesse âmbito; e ressaltando a importância da educação ao longo desses processos para que se tenha uso responsável e ético da comida e do uso dela.

Para além disso, o ativismo alimentar serve também para alertar sobre sistemas alimentares dominantes e para evidenciar ideologias por trás de cada um deles. Diante desse aspecto, sugere-se cautela com ele por existir a possibilidade do surgimento do fundamentalismo alimentar. Essa ressalva pode ser melhor interpretada quando se analisa o Plano da Fome Nazista (GERHARD, 2015) no qual o uso de estudos científicos sobre alimentação aliados à eugenia, à superioridade racial dos nazistas, serviu para incitar e ganhar o apoio da classe de trabalhadores rurais e alavancar uma guerra.

Valores sociais como saudabilidade, equidade, sustentabilidade, uso de recursos locais e valorização de saberes e fazeres tradicionais há também a reação dos “impérios alimentares” (VAN DER PLOEG, 2008), que acabam se valendo da luta, das pesquisas e estudos dos movimentos sociais e passam a adaptar suas ações capitalistas. As redes internacionais de fast-food são 
exemplo para visualizar essa atitude, a partir do instante em que passam a incluir nos menus de seus empreendimentos alimentos com rótulos de tradicionais, orgânicos, veganos, para atrair clientes conscientes - e essa é uma prática que vem se proliferando no varejo alimentar.

\section{COMO SE MANIFESTA A GASTROPOLÍTICA}

Recai sobre Arjun Appadurai (1981) o uso do termo gastropolítica em uma análise de qual era o papel dos alimentos na organização social indiana com foco no sul daquele país em 1981 -, e o termo serviu para designar conflitos e competições por recursos específicos econômicos e culturais que surgiam com as sociabilizações de alimentos. Appadurai (1981) ainda identificou o que estas ações significavam, o que tinham a dizer para o mundo, em que contexto emergiam e quais as consequências disso.

Aqui, se compreende gastropolítica como um campo de relações de poder que une alimentos e bebidas, culturas alimentares e cozinhas a estados/nações, instituições públicas, mercados, relações étnicas e identitárias cultural, social, gênero, raça. Sendo ela a causa ou o efeito de conflitos encontrados em determinados espaços e que tende a resultados distintos dependendo do contexto. Acredita-se, ainda, que a gastropolítica pode se fazer presente nos âmbitos do público e do privado, nos discursos, em ativismos de movimentos sociais e em tendências socioculturais. No entanto, atenta-se para o fato de que a gastropolítica pode também se vincular à estruturas comerciais, em função do apelo mercadológico de alimentos e bebidas, à proteção do patrimônio gastronômico, por meio de tombamentos em órgão oficiais de salvaguarda do patrimônio cultural ou por meio do uso de apelações de origem (COELHO-COSTA, 2014), e pelo modo como grupos e indivíduos se relacionam com identidades pessoais e alimentares.

A gastronomia passou um período sendo utilizada como meio de pesquisas acadêmicas, mas subutilizada no contexto do ativismo sociopolítico. No entanto, pode-se ressaltar que na atualidade já existe maior aproximação entre esses campos, principalmente quando se pode observar a comida como importante questão política, que permeia desde a produção e consumo de alimentos, que afeta economias, até a escassez de alimentos, que também afeta nações com fome e guerra (NESTLÉ, 2002) e com ideologias alimentares como veganismo. 
O interesse por gastropolítica, ou a política de alimentos, geralmente está aliado às lutas por direitos à alimentação, ao bem-estar e justiça social e coloca o indivíduo (ou coletivos) como sujeito(s) alimentar(es).

As indicações geográficas (IGs), surgidas ainda na antiguidade clássica, possivelmente possam ser entendidas como as primeiras ações de gastropolítica da humanidade. As IGs eram marcas de proteção especiais para proteger produtos agroalimentares e produtores, incialmente deu-se com o vinho, no qual selos e signos atestavam a qualidade e a procedência de origem de produtos e os diferenciava de falsificações que já eram comuns à época. (COELHO-COSTA, 2015) A ideia era simples: identificar e proteger produtores e produtos cuja produção regionalizada específica era tida como diferencial e bastante demandada no mercado internacional, como, por exemplo, o presunto da Gália, as tâmaras do Egito, as ostras de Brindisi, os vinhos de Corinto e os vinhos romanos de Falernum, de Alba e de Sorrento. (COELHO-COSTA, 2014)

As IGs resistiram ao tempo, se sofisticaram e hoje estão se tornando formas de proteções especiais de produtos ligadas à propriedade intelectual e asseguradas por diversas convenções internacionais, sendo responsáveis na proteção de lugares e regiões e do que neles são produzidos a partir do terroir e garantir aos consumidores exclusividade e especialidade de suas produções. (COELHO-COSTA, 2015, 2014) Muitos países pelo mundo ostentam sua lista vasta de indicações geográficas. Dentre os continentes, a Europa se destaca com mais de mil indicações geográficas que envolvem produtos do gênero alimentício e mais de mil e novecentas de vinhos. (COELHO-COSTA, 2014)

No Brasil, atualmente, estão registradas 74 indicações geográficas pelo Instituto Nacional de Propriedade Industrial (INPI), órgão responsável pela concessão de registro de dois diferentes tipos de indicações geográficas em uso no Brasil: a Denominação de Origem (DO) e a Indicação de Procedência (IP).

O INPI (BRASIL, 2019a) apresenta a divisão das 74 IGs registradas no Brasil da seguinte maneira: dentre as 20 DO registradas no Brasil, 11 são nacionais: o camarão da Costa Negra (CE); própolis vermelha e extrato de própolis vermelha dos Manguezais de Alagoas (AL); vinhos e espumantes do Vale dos Vinhedos (RS); café verde em grão e café industrializado torrado em grão ou moído da região do Cerrado Mineiro (MG, dentre outros) e 9 
estrangeiras (como a tequila mexicana, os vinhos verde e porto de Portugal, o queijo roquefort da França, entre outros). (BRASIL, 2019a) Já as 54 IP registradas são todas nacionais, como os seguintes exemplos de produções com seus respectivos estados de origem: a farinha Uarini (AM), o cacau Tomé-Açu (PA), o queijo Colônia Witmarsum (PR), o guaraná Maués (AM), a linguiça Maracaju (MS), o açafrão de Mara Rosa (GO), cajuína Piauí (PI), os vinhos e espumantes Monte Belo (RS), os biscoitos São Tiago (MG), dentre outros.

Outras ações importantes de gastropolítica advêm com a existência de formas de registro e tombamento de bens culturais ligados à alimentação no Brasil e no Mundo. Nesse quesito, o ano de 2003 marca a origem da salvaguarda do Patrimônio Cultural Imaterial no âmbito internacional. Avieli (2013) aponta a importância de um patrimônio culinário como um processo multidirecional que gera influências e desenvolvimento local. Neste último aspecto, observa a valorização e promoção do patrimônio culinário como vetor fundamental para o setor turístico. Mas, ter elementos gastronômicos figurando entre a lista de patrimônio cultural da humanidade vai para além disso, sobretudo quando se observa que não há humanidade sem comida e, configurar como patrimônio permite verificar que bens patrimonializados encontram-se em cooperação com sistemas diferentes que influenciam diretamente na educação, na política, nas relações sociais, culturais e econômicas distingue um povo do outro e valoriza memórias e raízes de uma sociedade ou grupo.

No Brasil, o Livro de Registro dos Saberes, do Instituto do Patrimônio Histórico e Artístico Nacional (Iphan) (BRASIL, 2019b), registra oito bens de caráter imaterial ligados à cultura alimentar e à gastronomia, são eles: o ofício das paneleiras de Goiabeiras - oriundo do bairro de Goiabeiras Velha, em Vitória, no Espírito Santo, inscrito em 2002, foi o primeiro bem cultural registrado pelo Iphan como Patrimônio Imaterial Brasileiro; o ofício das baianas de acarajé de Salvador, inscrito em 2005, traz aspectos da ritualização religiosa e compreende, além do modo de fazer o acarajé, os elementos associados à indumentária da baiana, a preparação do tabuleiro e dos locais onde se instalam; o modo artesanal de fazer queijo de Minas nas Regiões do Serro e das Serras da Canastra e do Salitre, inscrito em 2008; o modo de fazer cuias do Baixo Amazonas, no Pará, inscrito em 2015 . Outros registros ocorrem tais como: a produção tradicional e práticas socioculturais associadas à cajuína no Piauí, inscrito em 2014; o sistema agrícola tradicional de comunidades quilombolas do Vale do Ribeira, inscrito em 
2018; o sistema agrícola tradicional do Rio Negro, inscrito desde 2010; e, por último, inscrito em 2018, as tradições doceiras da região de Pelotas e Antiga Pelotas (Arroio do Padre, Capão do Leão, Morro Redondo, Turuçu).

No cenário mundial, atualmente, existe a inscrição de 20 elementos ligados à cultura alimentar e à gastronomia. Eles estão inscritos na lista representativa do patrimônio cultural imaterial da humanidade (UNESCO, 2019), são eles: o antigo método tradicional de vinificação Qvevri da Geórgia, ingressa na lista representativa do patrimônio cultural imaterial da humanidade em 2013; Nsima, a tradição culinária do Malawi, em 2017; a arte do Pizzaiuolo napolitano, na Itália, em 2017; a tradição de fazer e compartilhar Dolma no Azerbaijão, em 2017; a cozinha tradicional Mexicana, em 2010; a tradição da fabricação de kimchi na República Popular Democrática da Coréia (Coreia do Norte), em 2015; Kimjang, produzir e compartilhar kimchi na Coreia do Sul, em 2013; o pão de gengibre artesanal do Norte da Croácia, em 2010; Washoku, culturas. Essa lista pode ser complementada com os seguintes registros: alimentares tradicionais japonesas, principalmente para a celebração do ano novo, em 2013; a cultura e tradição do café Turco, em 2013; Lavash, a preparação, significado e aparência do pão tradicional como expressão da cultura na Armênia, em 2014; a dieta mediterrânea (presente em Chipre, Croácia, Espanha, Grécia, Itália, Marrocos e Portugal), em 2013; o conhecimento do cultivo da Mastiha ou mástique, uma resina proveniente de árvores da espécie Pistacia Lentiscus que é usada como especiaria, antisséptico bucal e utilizada em cosméticos desde 189 a. C., na ilha grega de Chios, inscrita na lista representativa do patrimônio cultural imaterial da humanidade em 2014; a refeição gastronômica dos franceses, em 2010; a cultura da cerveja belga, em 2016; Flatbread, a cultura do fazer e compartilhar pão Lavash, Katyrma, Jupka, Yufka no Azerbaijão, Irã (República Islâmica), Cazaquistão, Quirguistão e Turquia, em 2016; Oshi Palav (Pilaf), uma refeição tradicional e seus contextos sociais e culturais no Tajiquistão, em 2016; o café árabe, um símbolo de generosidade (Emirados Árabes Unidos, Arábia Saudita, Omã e Catar), em 2015; o Oshituthi shomagongo, festival de frutas de marula da Namíbia, em 2015; e a Festa de Khidr Elias e seus votos, no Iraque, inscrita na lista representativa do patrimônio cultural imaterial da humanidade em 2016.

A existência de um patrimônio gastronômico torna-se relevante na medida em que se valoriza a alimentação como elemento cultural importante e destaca o patrimônio alimentar como ativo cultural capaz de evocar a identidade 
cultural gastronômica de uma sociedade, usando aspectos tangíveis (comida, utensílios, ingredientes) e intangíveis (saberes e fazeres, simbologias) para gerar economia, força política, de transformação e desenvolvimento.

A relação entre alimentação e política também pode ser analisada a partir da diplomacia com destaque para banquetes e reuniões oficiais onde a comida surge como elemento agregador para relações sociais diversas, mas também como forma de conseguir status e poder e reafirmar identidade. (GOODY, 1982)

O prestígio político nas relações entre nações pode servir para analisar a influência e os poderes obtidos com diplomacia no âmbito das relações internacionais (ROOSEN, 1980), sendo um "espelho" da esfera política para refletir ações de como a diplomacia trata uma nação e como as relações de poder podem interferir nessa interação. (MORGENTHAU, 1985)

Nesse contexto, a ideia do soft power (poder brando) apresentado por Vuving (2009) e Nye (2004) como mudanças de comportamento por meio de cultura, simbolismo e percepção ajuda na caracterização da realidade e na análise dos resultados operacionais diplomáticos. $\mathrm{O}$ soft power e o prestígio dos alimentos, quando combinados, comunicam ações e exibem poder, que, aliados à diplomacia, podem facilitar ou complicar as relações diplomáticas e o acesso às sociedades e seus canais políticos.

Considerando que eventos que incluem alimentos e bebidas - almoços, jantares e banquetes - (GOLDSTEIN, 2008) são características fundamentais de encontros diplomáticos, Morgan (2008) cria o termo "gastronomia diplomática” para descrever as interações de poder baseadas no prestígio, usando alimentos e bebidas como meio de interação. Mas, gastrodiplomacia difere da diplomacia alimentar ou diplomática - grosso modo, essa última implica diretamente na ajuda alimentar em período de crise ou catástrofe que atingem alguns estados ou nações. É o caso, por exemplo, da assistência diplomática que busca unir nações para o envio de alimentos na tentativa de ajudar nas crises cíclicas de alimentos no Níger. (ORGANIZAÇÃO DAS NAÇÕES UNIDAS, 2010)

Em termos teóricos, gastrodiplomacia é diplomacia pública que gera comunicação entre governos e atores não estatais para os públicos estrangeiros. Sendo assim, a gastrodiplomacia se utiliza de experiências gastronômicas para fortalecer relações, difundir cultura, influenciar e engajar pessoas e sociedades.

Diplomatas utilizando a gastronomia como meio de exposição cultural e entretenimento é tão antigo quanto a própria diplomacia. Mas a gastrodiplomacia 
é produto da modernidade. Baseando-se nos estudos de Chapple-Sokol (2013, 2012), compreende-se diplomacia culinária como o uso de alimentos e bebidas, ou de cozinhas, como instrumento para criar compreensão intercultural, gerando a melhoria das relações e cooperações internacionais.

Chapple-Sokol (2013) divide a diplomacia culinária em dois tipos: diplomacia culinária pública - recai sob a missão diplomática que trabalha a diplomacia cultural, quando governos executam programas de valorização e de divulgação de suas cozinhas em outras nações, com ações de participações públicas em eventos e afins e a diplomacia culinária privada recai sob o diplomata ou personagens de alto poder político em encontros a portas fechadas, segue cerimônia e protocolo, onde a comensalidade e a cozinha do país apresentam-se como meio para a discussão diplomática, à mesa, para tomada de decisões.

No entanto, acrescenta-se aqui que a diplomacia culinária ou gastrodiplomacia de pessoa para pessoa - que pode recair sob o cidadão comum, que de maneira involuntária (ou até voluntária e proposital), faz uso da diplomacia cultural quando apresenta a cultura de um lugar a um visitante oriundo de outra cultura, incluindo-se a cultura gastronômica. Neste caso, apresenta-se menos formal do que os casos anteriores, e o turismo se apresenta como a atividade perfeita para a prática deste tipo de diplomacia culinária. (COELHO-COSTA, 2017)

$\mathrm{Na}$ atualidade, a gastrodiplomacia transcende as relações entre Estados e pode ser muito bem aplicada no engajamento de pessoas-para-pessoas e melhorar a compreensão cultural a partir dessa interação. Esse entendimento vai de encontro ao pensamento de Gotlieb (1991) quando este menciona sobre "uma nova diplomacia pública" que exige habilidades, técnicas e atitudes diferentes das encontradas na diplomacia tradicional. Observa-se, ainda, que nações com grande poder de influência e países com influência "mediana" têm investido na gastrodiplomacia para ganhar visibilidade no cenário mundial, é o caso do EUA, França, Peru, Coreia, Holanda, Tailândia, Japão, dentre outros. (COELHO-COSTA, 2017)

O uso de novas tecnologias nos meios de comunicação também é uma forma de atingir pessoas com a gastropolítica a partir da comunicação. Nesse sentido, as mídias digitais servem como meio para debates onde os agentes podem identificar-se e discutir suas ações e ideias. De forma coletiva ou individualizada as informações em rede permitem que o agente afete e seja 
afetado por informações. O uso da internet e das mídias sociais também se torna ação que propicia manifestações de gastropolítica.

A acessibilidade da rede mundial computadores ou World Wide Web (WWW) e o "exército de smartphones" tornam o indivíduo em um ser potencialmente criativo para a geração de conteúdo diversificado que atenda suas necessidades gastropolíticas. Esteja onde estiver, uma vez logado na rede, poderá expandir conhecimentos, críticas, apoios, participar de eventos on-line, discutir em fóruns, criar memes e até ser inconveniente em comentários (PHILLIPS; MILNER, 2017), maneiras de afetar e de ser afetado pela comunicação a partir da identificação com causas, da aproximação ou distanciamento com temas - isso fortalece identidades, afetividades e consolida a participação nas redes sociais.

A selfie também entra como arsenal gastropolítico. Ela serve como meio para retratar performances, provar militância e participação em ações ou para simples registro histórico. Memes ${ }^{1}$ e GIFs (Graphics Interchange Format ou formato de intercâmbio de gráficos) também podem servir como elementos de gastropolítica, quando se tornam reações de resposta para conteúdos vinculados na Internet. Geralmente associados ao humor, memes e GIFs ${ }^{2}$ utilizam personagens com alta visibilidade entre novelas, filmes e seriados para reagir de maneira rápida a conteúdos levando em consideração sua compreensão crítica e política e, muitas vezes, são maneiras mais sutis para evitar censura na rede. (PHILLIPS; MILNER, 2017)

O uso de hashtags é outro meio importante utilizado nas mídias sociais para chamar a atenção de campanhas na internet. Elas servem tanto para comunicar uma posição política quanto para chamar outras pessoas identificadas com o tema em questão a participar de movimentos e comunidades para discussões. No entanto, Phillips e Milner (2017) e Highfield (2016) ressaltam que elas também podem ser perigosas quando usadas por pessoas ou coletivos que utilizam esse recurso de forma pejorativa para humilhar,

1 Meme é termo grego que significa imitação. Entretanto, o conceito de meme usado na internet foi elaborado em 1976, pelo escritor e zoólogo Richard Dawkins, aparecendo em ‘The Selfish Gene' (O Gene Egoísta) como unidade de informação com capacidade de se multiplicar, por ideias e informações veiculadas de indivíduo para indivíduo, sendo a Memética o campo de estudo dos memes.

2 GIFs - Graphics Interchange Format, que traduzido literalmente para o portugues significaria formato para intercâmbio de gráficos - , 
insultar, culpar, atacar a imagem de outrem, de grupos ou organizações com posições diferentes.

\section{CONSIDERAÇÕES FINAIS}

Ao longo da história do desenvolvimento humano pôde-se observar a alimentação como ativo importante para o processo evolutivo. Contudo, as últimas décadas se destacam com maior atenção para o poder político da alimentação, apresentando ativismos e maior engajamento nas sociedades.

A politização da comida, observada desde o período em que há preocupação com a produção, estocagem, fornecimento e consumo de comida até as preocupações contra a fome e a justiça alimentar, confirma que as visões de desenvolvimento acabaram mudando e legitimando o interesse político pela alimentação.

Nesse sentido, reconhecer políticas alimentares das mais variadas - que abrangem desde o conhecimento cientifico sobre a comida, sobre identidade e sobre as expectativas para o futuro, por exemplo -, permitem compreender melhor os modelos alimentares - globais, nacionais, locais -, entender os conflitos oriundos deles e encontrar soluções para que essas situações sejam superadas, de maneira responsável, sustentável e democrática. Logo, isso explica o fato de a alimentação ganhar, cada vez mais, importância entre os estudos e pesquisas com abordagens múltiplas que evidenciam a importância da comida para as sociedades. O escopo teórico comprova a existência de ações políticas que envolvem o campo da alimentação e o entrelaçam a aspectos culturais, identitários, econômicos, de crescimento e de desenvolvimento nas sociedades.

A politização da alimentação pode ser observada a partir de relações variadas - sociais, culturais, políticas, econômicas -, legitimando o fato de alimentar e o que decorre dele. Assim, o aparecimento de indicações geográficas, da patrimonialização de bens gastronômicos, o surgimento de ativismos sociais, da gastrodiplomacia, do uso da internet e das mídias digitais como veículos para disseminar a politização da comida podem ser considerados ações de gastropolítica, que comunicam interesses e ideias variados, e que precisam ser analisados em seus respectivos contextos.

Ressalta-se a importância da existência do patrimônio gastronômico mundial e brasileiro, principalmente como elementos que marcam a 
identidade de sociedades e como ativos culturais capazes de movimentar trocas de relações nos mais variados campos. Também se fortalece o reconhecimento e a importância do soft-power que a comida desempenha para o contexto diplomático e incentiva-se estudos e pesquisas que enfoquem essa relação, em especial no contexto das relações internacionais do Brasil com o mundo e, quem sabe, se comprometendo a desenvolver trabalhos no âmbito da gastrodiplomacia.

As muitas possibilidades de analisar o papel das mídias sociais em uso na gastropolítica podem alimentar ideais e tornar o indivíduo como agente de macro ou micropolíticas sustentadas a partir das relações ocorridas na rede e fora dela. Entre as mídias digitais se pode observar efeitos conflitantes e intensidades distintas de interação para a gastropolítica, desde celebrar conquistas à lutar contra a fome; levantar discussões por uma alimentação saudável ou humilhar pessoas pelo peso; postar selfies com a comida preferida ou simplesmente comentar que está desejando comer queijo vegano, todas são possibilidades fáceis de se encontrar.

Por outro lado, ao mesmo tempo em que as mídias digitais oferecem recursos variados para externar identidades sociais, pensamentos políticos e representatividades tem-se que estar ciente de que ela também permite que haja reações e posições contrárias que, em alguns casos, vão do ridículo à agressividade. Entretanto, são recursos dos mais rápidos em termos de efeito para fazer expandir ideias e posicionamentos. A internet, as mídias digitais e as novidades que surgem com elas são excelentes meios de transmitir ideias ligadas à gastropolítica, considerando o efeito "cascata de informação” que elas possuem gerando interação e debates.

\section{REFERÊNCIAS}

ÁLVAREZ, M. El patrimonio ya no es lo que era: los recursos alimentarios entre la diferencia cultural y la desigualdad social. In: ALVAREZ, M.; MEDINA, F. X. Identidades en el plato. Barcelona: Icaria, 2008. p. 25-44.

APPADURAI, A. gastro politics in Hindu South Asia. American ethnologist, New York, v. 8, n. 3, p. 494 511, 1981.

AVIELI, N. What is 'local food?' Dynamic culinary heritage in the World Heritage Site of Hoi An, Vietnam. Journal of Heritage Tourism, London, v. 8, n. 2-3, p. 120-132, 2013.

BENHAMMOU, F. Nourrir l'humanité: une géopolitique de l'alimentation et de l'environnement. Ecologie politique, Lormont, n. 1, p. 17-32, 2009. 
BESTOR, T. C. Supply-side sushi: commodity, market, and the global city. American Anthropologist, Washington, D. C, v. 103, n. 1, p. 76-95. 2001.

BOURDIEU, P. O desencantamento do mundo: estruturas econômicas e estruturas temporais. São Paulo: Perspectiva, 1979.

BRASIL. INPI. Pedidos de indicação geográfica concedidos e em andamento. Brasília, DF, 2019a. Disponível em: http://www.inpi.gov.br/menu-servicos/indicacaogeografica/pedidos-de-indicacao-geografica-no-brasil. Acesso em: 25 maio 2019.

BRASIL. IPHAN. Livro de Registro dos Saberes: bens culturais imateriais. IPHAN, Brasília, DF, 2019b. Disponível em: http://portal.iphan.gov.br/pagina/detalhes/496?f bclid=IwAR2j6Ry3AbiPcHmFoZ3Yk__-FJHJJgUiVUp-w0lbaOXL_90fAZ9S57rdIxA. Acesso em: 15 ago. 2019.

CALDWELL, M. L. The Taste of Nationalism: food politics in postsocialist Moscow. Ethnos, London, v. 67, n. 3, p. 295-319, 2002.

CHAPPLE-SOKOL, S. Culinary Diplomacy Isn't Just American (Part 2): global Thai. Culinary Diplomacy, [s. l.], 22 out. 2012. Disponível em: http://culinarydiplomacy. com/2012/10/22/culinary-diplomacy-isnt-just-american-part-2-global-thai/. Acesso em: 20 maio 2018.

CHAPPLE-SOKOL, S. Culinary Diplomacy: breaking bread to win hearts and minds. The Hague Journal of Diplomacy, Leiden, v. 8, p. 161-183, 2013. Disponível em: https://culinarydiplomacy.files.wordpress.com/2013/06/hjd-off-print.pdf. Acesso em: 20 maio 2018.

COELHO-COSTA, E. R. C. As Indicações Geográficas (IGs) como elementos fortalecedores para a atividade turística. Revista Turismo: estudos e práticas, Mossoró, v. 3, n. 1, p. 25-50. 2014. Disponível em: http://periodicos.uern.br/index. php/turismo/article/view/1073/588. Acesso em: 15 ago. 2019.

COELHO-COSTA, E. R. C. El sabor de la influencia: la gastrodiplomacia y las indicaciones geográficas como instrumentos para promover la diplomacia cultural y el turismo. In: NORRILD, J. A. (coord.). Gastronomía y turismo: destinos con sal y pimienta. Buenos Aires: CIET, 2017. p. 20-51. Disponível em: https://www. academia.edu/31393334/Gastronom\%C3\%ADa_y_turismo_Destinos_con_sal_y_ pimienta_Cap\%C3\%ADtulo_3_El_sabor_de_la_influencia._La_gastrodiplomacia_y_ las_indicaciones_geogr\%C3\%Alficas_como_instrumentos_para_promover_la_ diplomacia_cultural_y_el_turismo. Acesso em: 9 ago. 2018.

COELHO-COSTA, E. R. C. Indicações Geográficas no Turismo Enogastronômico Brasileiro: turismo no país das iguarias. 2015. Dissertação (Mestrado em Gestão de Negócios Turísticos) - Centro de Estudos Sociais Aplicados, Universidade Estadual do Ceará, Fortaleza, 2015. 
COELHO-COSTA, E. R. C.; SANTOS, M. S. F. Considerações sobre cozinha patrimonial e turismo. Resgate: revista interdisciplinar de cultura, Campinas, v. 23, n. 2, p. 5-16, 2015. Disponível em: https://periodicos.sbu.unicamp.br/ojs/index.php/ resgate/article/view/8645802/13100. Acesso em: 15 ago. 2019.

COUNIHAN, C. M.; KAPLAN, S. L. Food and Gender: identity and power. Amsterdam: Harwood Academic Publisher, 1998.

CURY, P.; MISEREY, Y. Une mer sans Poisson. Paris: Calmann-Lévy, 2008.

FORSON, P. W.; COUNIHAN, C. Taking food public: redefining foodways in a changing world. London: Routledge, 2012.

GERHARD, G. Nazi Hunger Politics: a history of food in the third reich. Lanham: Rowman \& Littlefield, 2015.

GOLDSTEIN, E. The Politics of the State Visit. The Hague Journal of Diplomacy, Leiden, v. 3, n. 3, p. 153-178, 2008.

GOODY J. Cooking, Cuisine and Class: a study in comparative sociology. Cambridge: Cambridge University Press, 1982.

GOTLIEB, A. I'll be with you in a minute, Mr. Ambassador: the education of a Canadian diplomat in Washington. Toronto: University of Toronto Press, 1991.

HIGHFIELD, T. Social Media and Everyday Politics. Cambridge: Polity. 2016.

HIROKO, T. Delicious food in a beautiful country: nationhood and nationalism in discourses on food in contemporary Japan. Studies in Ethnicity and Nationalism, London, v. 8, n. 1, p. 5-30, 2008.

HISTÓRIA do Partido Verde no Brasil. Partido Verde, São Paulo, 2012. Disponível em: https://web.archive.org/web/20150924083342/http://www.pvsp.org.br/ index.php/2012-05-18-14-06-42/20-partido-verde/historia-do-partido-verde-nobrasil/158-historia-do-partido-verde-no-brasil.html. Acesso em: 15 ago. 2019.

KARAOSMANOĞLU, D. Surviving the Global Market: turkish cuisine under construction. Food, Culture \& Society, [Tucson], v. 10, n. 3, p. 425-448, 2007.

LE VELLY, R. Sociologie des systèmes alimentaires alternatifs: une promesse de différence. Paris: Presses de l'Ecole des Mines, 2017.

MACHADO, J. A. S. Ativismo em rede e conexões identitárias: novas perspectivas para os movimentos sociais. Sociologias, Porto Alegre, v. 9, n. 18, p. 248-285, 2007.

MATTA, R.; GARCÍA, M. E. The "Gastro-Political Turn" in Peru. Anthropology of food, [s. l.], n. 14, 2019. Disponível em: https://journals.openedition.org/aof/10061. Acesso em: 15 ago. 2019.

MINTZ, S.W. Food at moderate speeds. In: WILK, R. (org.). Fast food/slow food: the cultural economy of the global food system. Lanham: Altamira, 2006. p. 3-12. 
MINTZ, S.W. Sweetness and Power: the place of sugar in modern history. New York: Penguin, 1985.

MORGAN, L. Diplomatic Gastronomy: style and power at the table. 2008. Degree (Degree in Gastronomy) - School of History and Politics, University of Adelaide and Le Cordon Bleu, Adelaide, 2008.

MORGENTHAU, H. J. Politics among nations: the struggle for power and peace. New York: Knopf, 1985.

NESTLÉ, M. Food politics: how the food industry influences nutrition and health. Berkeley: University of California Press, 2002.

NYE, J. Soft power and American foreign policy. Political Science Quarterly, New York, v. 110, n. 2, p. 255-270, 2004.

ORGANIZAÇÃO DAS NAÇÕES UNIDAS. ONU pede medidas para combater crises alimentares recorrentes na região de Sahel, na África. ONUBR, Brasília, DF, 2010. Disponível em: https://bit.ly/2nDIZOu. Acesso em: 9 ago. 2018.

PHILLIPS, W.; MILNER, M. R. The Ambivalent Internet: mischief, oddity, and antagonism online. Cambridge: Polity Press, 2017.

POULAIN, J. P. Sociologies de l'alimentation: les mangeurs et l'espace social alimentaire. Paris: PUF, 2002.

ROOSEN, W. Early Modern Diplomatic Ceremonial: a systems approach. The Journal of Modern History, Chicago, v. 52, n. 3, p. 452-476, 1980.

RUDY, K. Locavores, Feminism, and the Question of Meat. The Journal of American Culture, Malden, v. 35, n. 1, p. 26-36, 2012.

THÉRY, H. Le Brésil peut-il devenir la "ferme du monde"?, Politis, [França], n. 1047, p. 9-15, 2009.

UNESCO. Browse the Lists of Intangible Cultural Heritage and the Register of good safeguarding practices. UNESCO, Paris, 2019. Disponível em: https://ich.unesco.org/ en/lists. Acesso em: 15 ago. 2019.

VAN DER PLOEG, J. D. Camponeses e Impérios Alimentares: lutas por autonomia e sustentabilidade na era da globalização. Porto Alegre: Ed. UFRGS, 2008.

VUVING, A. L. How Soft Power Works. Toronto: American Political Science Association annual meeting, 2009.

YOUNT-ANDRÉ, C. Empire's leftovers: eating to integrate in secular. Food and Foodways, Paris, v. 26, n. 2, p. 124-145, 2018. 


\title{
"CULTURA ALIMENTAR LOCAL" E REFLEXÕES SOBRE O "LUGAR" MÚLTIPLOS SENTIDOS EM TRANSFORMAÇÃO'
}

\author{
CAROLINA DALTOÉ DA CUNHA \\ SHIRLEY DONIZETE PRADO \\ FABIANA BOM KRAEMER \\ LUCIANE DA COSTA MOÁS
}

\section{A PROBLEMÁTICA EM PAUTA}

Até a década de 1970, acreditava-se que a produção insuficiente de alimentos era o determinante básico da fome no mundo. Com o advento da internacionalização das economias mundiais e do aumento da produção agrícola - a Revolução Verde -, o argumento da produção insuficiente de alimentos caiu por terra. Outras problemáticas foram colocadas nas pautas acadêmicas de pesquisa e nas políticas públicas em torno da alimentação, tais como: as questões ambientais; a segurança alimentar e nutricional; a qualidade dos alimentos, em termos de contaminações e de processos de industrialização;

1 Este trabalho é oriundo do projeto de dissertação de mestrado ora intitulado "O espaço geográfico como ferramenta teórica para estudos no campo da Alimentação e Nutrição: considerações sobre o conceito de lugar", desenvolvido no Programa de Pós-Graduação em Alimentação, Nutrição e Saúde do Instituto de Nutrição da Universidade do Estado do Rio de Janeiro, Brasil. 
as identidades alimentares, uma vez que uma homogeneidade do consumo de alimentos pelo mundo estaria sendo anunciada como parte do processo de globalização econômica e das culturas.

Para Milton Santos (2000), a globalização é, de certa forma, o ápice do processo de internacionalização do mundo capitalista. Nesse contexto, alguns estudiosos entendem que a comida se tornou mercadoria de valor econômico em escala global, resultado do movimento do capitalismo de fusão entre empresas agroalimentares, expansão dos mercados em desenvolvimento, ampliação da capilaridade de distribuição dos produtos. Análises de cunho macroestrutural sugerem - ainda que reconhecendo as articulações entre os processos derivados da globalização com a cultura local, a religião, o gosto, o simbolismo e a identidade - que a comida tem sido produzida primordialmente como uma mercadoria sob as premissas de um sistema e de uma política agroalimentar de caráter global, dominada por corporações agroalimentares transnacionais, o que envolve uma forma legitimada de agrobiopoder e de ameaça à soberania alimentar. ${ }^{2}$ (AZEVEDO, 2017)

Para antropóloga Silvia Carrasco i Pons (2005), estaríamos diante de um processo de aculturação alimentar, ou seja, perdendo o conhecimento tradicional de manipulação dos alimentos em decorrência da monetarização de seu acesso, da introdução massiva de métodos e produtos novos para exportação, da importação em larga escala de produtos refinados, além da redução das áreas circundantes às moradias que antes eram primordialmente destinadas aos cultivos de autoconsumo. Claude Fischler (2015) defende que, em decorrência desses processos, as regras culinárias que estruturavam a "cultura alimentar tradicional” estariam passando por um processo de desinstitucionalização. A força reguladora que estruturava a gastronomia estaria sendo substituída pela "gastro-anomia”, ou seja, um cenário alimentar no qual códigos e normas que enquadram culturalmente o comer encontram-se fragilizadas, rachadas e desordenadas. $\mathrm{O}$ crescimento e proliferação de empresas transnacionais de fastfood, como McDonalds, KFC, Burguer King, Subway, Domino's são exemplos dessa realidade em expansão. ${ }^{3}$

2 O conceito de soberania alimentar foi definido formalmente pela Via Campesina Internacional como o direito de cada nação a manter e desenvolver os seus alimentos, tendo em conta a diversidade cultural e produtiva.

3 As empresas transnacionais acabam por eliminar a concorrência com os pequenos e médios negócios, aumentando ainda mais a dependência dos consumidores. (OSWALD, 2011) Nos mercados altamente 
No entanto, como nos indica Milton Santos, se também olharmos por outro ângulo, o processo de globalização possibilita reconhecer fatos indicativos da emergência de uma nova história que aprofunda ainda mais a mistura de povos, culturas e gostos em todos continentes aflorando junto a estes uma mistura de "filosofias".

Trata-se de uma verdadeira sociodiversidade, historicamente muito mais significativa que a própria biodiversidade, ou seja, a emergência de uma cultura popular que se serve dos meios técnicos - antes exclusivos das culturas de massas. (SANTOS, 2000, p. 21)

Nesse sentido, Doreen Massey (2005) ressalta que a globalização é um projeto cuja naturalização conduz à descrição do mundo como ele é ou será inevitavelmente. Para a geógrafa, esse tipo de cosmologia homogeneizadora faz como que não reconheçamos as trajetórias, culturas e potencialidades dos diferentes lugares, obliterando as multiplicidades e heterogeneidades contemporâneas. Nessa linha, Dias e demais autores (2014) consideram que o sistema agroalimentar moderno ${ }^{4}$ apresenta contradições e deposita no conceito de comida - alimento na cultura - uma centralidade para o entendimento das suas ambiguidades. Sob esta perspectiva, a comida torna-se um tema frutífero para explorar os múltiplos significados da globalização, uma vez que expõe a complexidade de um peculiar fenômeno que transcende o aspecto econômico.

Diante desse cenário ambíguo e na tentativa de limitar certos impactos desse processo sobre as práticas alimentares da sociedade, observa-se, no Brasil, um conjunto de esforços no âmbito das políticas públicas que se propõem a contribuir para o enfrentamento da pandemia de obesidade - espécie de política global - e vão no sentido da preservação de práticas

concentrados, as grandes empresas determinam da forma mais conveniente a padronização no consumo de alimentos.

4 Para Pellerano (2014), o sistema agroalimentar trata da combinação compreendida como mais adequada entre diferentes possibilidades de produção (caça, coleta, cultivo), distribuição (centralizada ou não), transação comercial (compra e venda, troca, oferenda), preparo (comer cru ou cozido, e de que forma transformar esse alimento), combinação de ingredientes (arroz com feijão, como na cozinha brasileira, ou com macarrão cabelo de anjo também de arroz, como na cozinha árabe) e consumo (sozinho, com companhia, à mesa de jantar, na lanchonete, caminhando pela rua). 
alimentares e dos cuidados individuais com a saúde articulando as categoria "tradicional”, "saudável” e "ambiente” através da normatização do espaço e da "cultura local".

Tendo em vista o fenômeno da globalização e os movimentos no sentido da restauração das "culturas alimentares tradicionais" em políticas públicas de alimentação brasileira guiadas pelos campos políticos e científicos envolvidos, registramos a imprescindibilidade de se analisar relações entre a alimentação, a cultura e o espaço. Para tal buscaremos integrar diferentes abordagens teóricas sobre "lugares" e "cultura", com destaque para aquelas oriundas do campo da Geografia Humana, tendo como objetivo problematizar o contexto socioespacial em que consumo de alimentos se insere na atualidade brasileira e a razoabilidade de algumas orientações presentes no que tange a preservação de culturas alimentares "tradicionais”, "genuínas”, “saudáveis" e "locais".

Dessa forma, na primeira parte desta exposição contextualizamos o cenário brasileiro nesses espaços-tempos globais em sua interface com o campo da Alimentação e Nutrição assinalando para as principais problemáticas associadas, a fim de situar o debate da globalização da alimentação no Brasil e suas conexões com o processo de reconfiguração socioespacial pelo qual passamos. A segunda seção procura estabelecer uma aproximação teórica sobre as categorias de "espaço" e "lugar" apontando para os múltiplos interesses e sentidos alimentares que atravessam aquilo que as ciências nomeiam como "local" no contexto anteriormente enunciado. Também apontamos para as repercussões que algumas formas de imaginar o espaço promoveram sobre a ideia corrente cultura local, tradicional ou genuína.

Destaca-se que neste estudo procuramos avançar através de uma concepção de "lugar" que ultrapassasse a materialidade em que o espaço vem sendo reduzido em algumas abordagens, sem, no entanto, desconsiderá-la de nossa análise. Para tal abordamos a temática das formas espaciais simbólicas, tomando-as como suportes de mensagens e de símbolos que se relacionam com as múltiplas identidades de lugar e os múltiplos sentidos que a comida assume nestes. O que adiantamos, é a que as geografias das relações sociais estão em mutação com o processo de internacionalização do mundo, tornando ainda mais complexas as relações sociais mediadas pela comida no espaço, fazendo com que surjam novas questões em torno daquilo que poderíamos nomear como "lugares de alimentação" e “cultura local”. 


\section{GLOBALIZAÇÃO E ALIMENTAÇÃO NO BRASIL: UM PANORAMA DAS DIMENSÕES SOCIOESPACIAIS ENVOLVIDAS NO FENÔMENO ALIMENTAR CONTEMPORÂNEO}

Para Milton Santos (1988), o mundo encontra-se organizado em subespaços articulados dentro de uma lógica global. Com a internacionalização das economias mundiais, os segmentos mais competitivos da indústria de alimentos vêm apresentando novas configurações em função de movimentos de fusões e aquisições de multinacionais que, estrategicamente, procuram fortalecer-se através da formação de oligopólios. A americana Cargill por exemplo, é fornecedora, no Brasil, de imensa gama de produtos alimentícios. Desde 2006, a empresa atua em atividades que vão desde o esmagamento de oleaginosas para produção de farelos para alimentação animal, passando pelas indústrias de biocombustíveis, até a produção de maionese, atomatados, margarinas e outros produtos alimentares. A Cargill é detentora das marcas Soya, Delícia, Primor, Salada, Cardeal, Salsaretti, Suprema e Gradina.

Em situação similar, a empresa holandesa Bunge encerrou, no ano de 2016, com vendas de 9,790 bilhões de dólares. (MELHORES..., 2017) Sua área de atuação perpassa o setor de originação de grãos e processamento de soja e trigo, a fabricação de produtos alimentícios e até mesmo serviços portuários. Nessa conjuntura, destaca-se que o agronegócio é uma das esferas econômicas da produção de alimentos no Brasil que não apresenta indicativos de retrocesso e segue sobrelevando o Brasil no cenário internacional. Com injeção pesada de "tecnologia" em todas as etapas do processo produtivo, a produção de soja, carro-chefe da agricultura brasileira, ultrapassou a barreira de 114,843 milhões de toneladas no ano de 2018, segundo dados disponibilizados pela Empresa Brasileira de Pesquisa Agropecuária. (EMBRAPA, 2019)

A vista de tal processo, ressalta-se que a reestruturação produtiva agropecuária pela qual passa o cenário brasileiro caracteriza-se pela produção de commodities, combustíveis renováveis, frutas tropicais e matérias-primas para vários ramos agroindustriais, com seu funcionamento regulado cada vez mais pela economia de mercado, em razão de demandas voltadas primordialmente à exportação e menos as demandas internas. Tal modelo de produção agrícola vem sendo fortemente articulado ao planejamento da 
agricultura nacional e à subalternização da agricultura familiar, responsável pela maior parte da produção alimentar destinada a economia doméstica.

No entanto, não se pode ignorar que a agricultura familiar está presente em $84 \%$ dos estabelecimentos de comércio agropecuários e responde por aproximadamente $33 \%$ do valor total da produção do meio rural. (IBGE, 2009) Importante aqui registrar a existência de critérios legais de enquadramento dos agricultores nos padrões da agricultura familiar, estipulados segundo a Lei $\mathrm{n}^{0} 11.326$, de 24 de julho de 2006. Por meio desse enquadramento, o agricultor passa obter com maior facilidade benefícios estatais, tal como o acesso a financiamentos. Nesse sentido destaca-se que o aumento da produtividade e integração ao mercado global são prometidos a essa categoria de trabalhadores por meio da compra de maquinário agrícola, de sementes geneticamente modificadas e pelo uso de insumos como fertilizantes e agrotóxicos fornecidos por empresas como a Monsanto (Estados Unidos), Syngenta (Suíça), Dupont (EUA), Basf (Alemanha), Bayer (Alemanha) e Dow (EUA). Para Santos (1988) quanto mais modernizada a vida agrícola, mais amplas são suas relações com o longínquo uma vez que só a produção direta se dá localmente. A garantia de participar de uma lógica que é extralocal insere essas atividades em nexos cada vez mais extralocais.

Dentro dessa lógica, até mesmo os projetos de desenvolvimento agrícola nacionais e das próprias indústrias locais estão subordinados ao capital de natureza mundial. (SANTOS, 1988) Assim, ao cabo, o enquadramento legal do campesinato aos padrões da agricultura familiar pode representar certa subordinação destes ao modelo de produção hegemônico e à matriz de produção tecnológica dominante. Em outras palavras, também os pequenos agricultores estão vinculados aos produtores de sementes, produtos químicos e equipamentos, além das redes de distribuição das grandes corporações. Para Santos (1994) com o processo de globalização estaríamos, cada dia mais, diante de um território nacional de economia internacional.

Como a globalização, o que temos é um território nacional da economia internacional, isto é, o território continua existindo, as normas públicas que o regem são da alçada nacional, ainda que as forças mais ativas do seu dinamismo atual tenham origem externa. Em outras palavras, a contradição entre o externo e o interno aumentou. (SANTOS, 1994, p. 76) 
Cabe ressaltar que, dentre as múltiplas formas de apropriação e influência sobre o espaço exercidas pela indústria agroalimentar, a difusão de tecnologias agrícolas importadas merece destaque, pois vem contribuindo para que a concentração fundiária no país seja ampliada. Em A natureza do Espaço, de 1996, o estudioso nos lembra que vivemos em uma era da "inovação galopante" caracterizada pela rapidez com que geograficamente se difundem as tecnologias no mundo. Para o autor, o casamento entre a técnica e a ciência veio reforçar a relação que então se esboçava entre ciência e produção. A versão atual deste casamento, a que ele chama de tecnociência, situa a base material e ideológica onde se fundamos discursos da globalização.

A tecnociência é responsável pelo aprofundamento do processo criativo de novos objetos, novas engrenagens, novos materiais e novas apropriações das virtualidades da "natureza", conformando o que Santos (1996) conceitua como sistemas técnicos. Esses sistemas atuam desalojando os sistemas precedentes autônomos ou mesmo incluindo-os em sua própria lógica segundo graus diferenciados de dependência e quando então instalam-se nos lugares, os fazem como sistemas integrados a outros sistemas representativos do sistema econômico hegemônico mundial.

De acordo com o autor, os sistemas técnicos são, sobretudo, sistemas invasores, no entanto, seus limites de invasão são controlados pela divisão do trabalho e pelas condições de densidade dos lugares não se concretizando de maneira homogênea no espaço e nem garantindo integração uniforme a aqueles que os incorporam. Assim, apesar da aderência de muitos agricultores familiares aos sistemas técnicos dominantes extralocais, o próprio mercado global se mostra pouco receptível às lógicas de produção em pequena escala, fazendo com que muitos não tenham como arcar com os custos da produção tecnológica e vendam suas terras aos que possuem maior capital de investimento, aprofundando o processo de concentração fundiária no país. Segundo dados do Instituto Nacional de Colonização e Reforma Agrária (INCRA, 2014), 51,18\% das terras agrícolas no Brasil estão concentradas nas mãos de apenas $1 \%$ dos proprietários rurais.

Nesse contexto, para vislumbrarmos as diferenças socioespaciais derivadas dessa configuração territorial desigual, cabe elucidar que qualquer localização inserida nos limites políticos brasileiros necessariamente pertence a um município e este, por sua vez, deve dispor de uma sede administrativa. 
Segundo o Instituto Brasileiro de Geografia e Estatística (IBGE) essa sede político-administrativa recebe o título de "cidade", independentemente do número de habitantes e de suas dinâmicas sociais. Ressalta-se que dos 5.570 municípios brasileiros, apenas $0,8 \%$ têm mais de 500 mil habitantes - uma vez que estes municípios também abrangem as áreas de concentração da produção agrícola brasileira, ou seja, grandes vazios demográficos. Por outro lado, em discrepância, observa-se que $21,8 \%$ da população do país (45,5 milhões) vive no estado de São Paulo. Somente a capital abriga cerca de 12,2 milhões de habitantes e sua região metropolitana em torno de 19 milhões, ocupando a $4^{\mathrm{a}}$ posição no ranking das maiores aglomerações urbanas do mundo. (SÃO PAULO, 2018)

Assim, apesar de o país possuir muitas cidades por abrigar número significativo de municípios, estes não são homogêneos quantitativa ou qualitativamente. Parte massiva da população é atraída para o Sudeste, onde concentram-se as metrópoles brasileiras, fazendo com que as regiões administrativas como Centro-Oeste e Nordeste apresentem baixa densidade demográfica - 8.75 e 34.15 habitantes por quilômetro quadrado, respectivamente - em contraponto a Região Sudeste, que apresenta nada menos que a média de 86.92 habitantes por quilômetro quadrado. (IBGE, 2010)

Dessa forma, torna-se evidente a atuação do processo de internacionalização das economias mundiais, o papel da agroindústria de alimentos sobre a configuração territorial brasileira e sua respectiva influência sobre o crescimento das áreas metropolitanas do País. Nessa mesma direção, têm destaque a especulação fundiária, os conflitos em torno de terras e os fluxos de capitais que circulam em busca de oportunidade de negócios; conflitos que extrapolam a dimensão econômica da produção de alimentos com consequências políticas e ambientais, como por exemplo, a ocupação do solo da Região Amazônica, do Cerrado e do Pantanal. Outro fator não menos importante, é o interesse na mineração que também tensiona as questões políticas da agroindústria.

Em síntese, podemos afirmar que a concentração fundiária estrutural vem sendo intensificada pela propagação do ideário do progresso, materializados nos sistemas técnicos extralocais que se capilarizam entre grandes e pequenos produtores de alimentos do interior do país, desalojando boa parte da população campesina, que então vislumbra nas grandes cidades a possibilidades de sobrevivência. A Região Sudeste como um todo - São 
Paulo em especial -aparece neste ensaio como ilustração deste movimento de deslocamento demográfico com a finalidade de demonstrar que tais processos não se apresentam desvinculados das lógicas de produção, distribuição e consumo de alimentos e nem mesmo das novas formas sociais de consumo de alimentos que afloram da necessidade de adaptação das pessoas a tais circunstâncias.

Tangenciando o crescimento generalizado da sociedade urbana, com destaque para as grandes metrópoles brasileiras, emerge a outra face do fenômeno alimentar contemporâneo e com ela a manifestação - ainda que controversa - da obesidade, tema relevante e caro para o campo da Nutrição e Alimentação, este que a toma, precipuamente, como uma categoria definida pela perspectiva biomédica. Em diversas abordagens, associa-se à obesidade uma complexa trama que envolve o consumo de alimentos considerados de baixa qualidade nutricional e seu alto valor energético agregado - sublinhe-se aqui, fornecidos pelos mesmos oligopólios e sistemas técnicos instalados nas áreas voltadas para a produção de alimentos. Sob outra ótica ainda, Alencastro e demais autores (2017) consideram fundamental coopreender a obesidade também a partir de aspectos culturais e simbólicos e, destacamos aqui, socioespaciais que o envolvem.

Trata-se, sobretudo de abordá-la-como um fenômeno correlacionado aos diversos valores implicados neste assunto complexo como, por exemplo, o conflito de interesses da indústria farmacêutica, da indústria de alimentos, a prescrição e indicação de tratamento, o desejo, a felicidade, a autonomia e o valor da vida. (ALENCASTRO et al., 2017, p. 163, grifo nosso)

No que tange a sua dimensão socioespacial, assistimos o tecido urbano sendo submerso pela crescente oferta de alimentos considerados "nutricionalmente não saudáveis”, cujos desenvolvimento, processamento e distribuição também se encontram coordenados pela tecnociência, informada pelos interesses das empresas transnacionais, conforme já destacado.

Para além do adequado ou inadequado, vislumbra-se aqui evidenciar processos relativos às transformações socioespaciais na atualidade. Entre os diversos fatores socioespaciais que configuram a emergência de novas formas de comensalidade no conjunto dos diferentes lugares que constituem as regiões predominantemente metropolitanas, destacamos: a tendência de 
deslocamento das habitações de baixa renda para localizações periféricas, uma vez que as áreas centrais vem passando por intensos processos de revalorização, ${ }^{5}$ tornando cada vez mais longos os trajetos da população de classes sociais menos favorecidas da casa para o trabalho; a precarização dos transportes públicos e a ineficácia das vias de circulação que integram as zonas periféricas aos centros comerciais; a verticalização das moradias cada vez mais acentuada, com aumento da densidade populacional; e o incremento da frota de carros, motocicletas, caminhonetes, caminhões que inundam o mercado e as ruas tendo como desfecho engarrafamentos intermináveis e a deterioração das condições de vida dos trabalhadores urbanos. Ao cenário caótico das grandes cidades, somam-se ainda a crise econômica e o desemprego que levam milhares de pessoas a trabalhar em condições precaríssimas, por exemplo, como vendedores ambulantes de alimentos e bebidas - geralmente, industrializados em porções individualizadas - nos inúmeros pontos de espera de ônibus ou mesmo caminhando entre os veículos na lentidão crônica do trânsito.

Como consequências relacionadas a este complexo processo de reconfiguração territorial contemporâneo, a literatura no campo alimentar-nutricional aponta para a redução do tempo destinado ao preparo e ao consumo de alimentos in natura e para a desestruturação das refeições, que vem gradativamente sendo substituídas por lanches rápidos e alimentos pré-prontos, industrializados congelados, contribuindo para a diluição das formas de relacionamento entre as pessoas e as comidas que se davam tradicionalmente à mesa. ${ }^{6}$ (ARNAIZ, 2005; PROENÇA, 2010)

A redução do consumo de alimentos “tradicionais”, "saudáveis” em “ambientes adequados” pode ser considerada, então, como fenômeno

5 Por vezes, tal mecanismo se insere em uma lógica global de remodelação dos centros urbanos para que estes possuam a forma das 'cidades globais' encarecendo o custo de vida nestas áreas.

6 Os alimentos ultraprocessados, com alto teor energético e baixo valor nutricional são cada vez mais utilizados devido a praticidade de transporte, baixo preço e longa durabilidade. Um pacote de biscoito, por exemplo, pode ficar semanas exposto numa barraca de vendedor instalado em alguma calçada ou numa bolsa, mochila ou ainda na gaveta da mesa de trabalho, ao contrário de uma fruta ou de refeição preparada na hora, o que costuma ser mais caro e com prazo de validade mais curto. Uma lasanha congelada comprada no supermercado possibilita a preciosidade de algum descanso ao corpo/mente por não exigir o trabalho, a disposição emocional e o tempo de seu preparo, que vão desde a compra dos ingredientes até a limpeza final da cozinha. Evidentemente, não se reduz a isso o que move alguém a optar por ingerir produtos alimentícios pré-prontos ou prontos e industrializados em processos de produção altamente complexos, mas são alguns exemplos que ilustram a movimentação em tela. 
atravessado por vasto leque de condições que vão desde projetos macroeconômicos de organização territorial no plano internacional, passando por setores de planejamento urbano das cidades, até as transformações socioculturais derivadas de tais processos, fazendo com que cada vez menos tenhamos possibilidades de agir de acordo com prescrições e normas ditadas pela racionalidade nutricional vigente. Para Viana e demais (2017), a racionalidade nutricional se refere às práticas alimentares atentas ao permanente cuidado em manter na alimentação o equilíbrio de nutrientes, ainda que em detrimento do prazer de comer ou das possibilidades materiais para que essas normas de cunho biomédico sejam cumpridas. Tais práticas alimentares sinalizam preocupações centradas no "consumo racional de alimentos" e com a "alimentação balanceada". Neste sentido observa-se que esta abordagem vem procurando estabelecer alianças teórico-metodológicas com concepções oriundas da geografia teórico quantitativa, ${ }^{7}$ tomando o espaço geográfico como materialidade quantificável, cuja finalidade encontra-se sobretudo na construção de modelos sobre a realidade que não seriam apenas descritivos, mas prospectivos. ${ }^{8}$ A convergência de tais abordagens tem, sobretudo, a finalidade de subsidiar importantes projetos de planejamento e de gestão sobre o urbano local enquadrando espaços múltiplos em critérios sanitários e de saúde, o que nada tem de neutro ou de estritamente técnico.

\section{ESPAÇO E LUGARES EM TRANSFORMAÇÃO}

Compreendendo o espaço enquanto processo multidimensional e em crítica a uma forma estritamente técnica de definição destes, Milton Santos (1978, p. 67) coloca que “[...] um processo multidimensional não pode estar contido

7 A Geografia Teórico-Quantitativa se consolidou no contexto socioeconômico que vivia o mundo no período pós-Segunda Guerra. Nesse sentido, como explicita Yves Lacoste (1976, p. 10) muito mais que uma série de estatísticas ou um conjunto de escritos, a cartografia torna-se a forma de representação geográfica por excelência. Coloca o autor: "[...] é sobre a carta que devem ser colocadas todas as informações necessárias para a elaboração de táticas e de estratégias. Tal formalização do espaço, que é a carta, não é nem gratuita, nem desinteressada: meio de dominação indispensável”. Nesta vertente, a estatística é o principal caminho para se chegar à comprovação de hipóteses e esclarecimentos de fenômenos geográficos e sua finalidade a interferência do Estado sobre seus territórios.

8 Os Cenários Prospectivos são configurações de imagens de futuro condicionadas e fundamentadas em jogos coerentes de hipóteses sobre os prováveis comportamentos das variáveis supostamente determinantes do objeto de planejamento. Assim, a pesquisa prospectiva sobre o espaço tem como objetivo, permitir ao analista prever decisões “adequadas” às suas aspirações. (SANTOS, 1978) 
em um modelo linear porque não se trata aqui de procurar relações de causa e efeito, mas de estabelecer a rede de causalidades em diferentes níveis, o que seria melhor chamar de contexto”.

Por esse ângulo, o espaço é um conjunto de possibilidades que a partir do desenvolvimento dos meios de comunicação e transporte tornou-as ainda mais interligadas e interdependentes através dos lugares. O lugar é um ponto do mundo onde se realizam algumas das possibilidades da globalidade, ou seja, é parte do mundo e desempenha um papel em sua história: "[...] quanto mais os lugares se mundializam, mais se tornam singulares e específicos” (SANTOS, 1988, p. 34), isto é, tornam-se únicos e conferem heterogeneidade ao espaço geográfico. Neste sentido, o autor ressalta que os fenômenos de evolução que constituem propriamente a vida dos lugares e das pessoas não podem ser apenas objetos de um tratamento matemático, pois existe um agir simbólico, que não é regulado por cálculos e compreende formas afetivas, emotivas, rituais.

A compreensão da dinâmica dos lugares impõe que se tenha em conta os processos planetários em curso, considerando que estes incidem desigualmente sobre os lugares de produção e sobre os lugares de vida. Exigem abordagens teóricas que integrem tanto análises de cunho macroestrutural, quanto a vida cotidiana das pessoas. O debate teórico sobre os "lugares" em sua interface com a alimentação contemporânea pode contribuir para compor saberes em face dessa complexa trama que envolve os sentidos e significados do comer em espaços-tempos globais.

Muitos autores afirmam que vivemos em uma época onde as coisas estão se "acelerando" e disseminando por toda superfície planetária. "Mais pessoas viajam com mais frequência para lugares mais distantes. Suas roupas são provavelmente feitas numa variedade de países que vão da América Latina ao sudeste asiático. Seus jantares consistem em comida importada do mundo inteiro". (MASSEY, 2000, p. 177)

No entanto, ao passo que hoje falamos de uma transgressão de fronteiras e dos espaços de fluxos, identifica-se simultaneamente o imaginário de um tempo em que esses limites se mostravam impermeáveis, no qual "culturas genuínas" constituíam-se com solidez duradoura, permanecendo até os dias atuais. Sinalizando certo alinhamento a esta última perspectiva, há entendimentos de que campanhas publicitárias que acompanham a monetarização e a internacionalização da alimentação na modernidade corroboram para a 
desvalorização das “culturas alimentares genuínas”. Considera-se um bom exemplo a marca Gallo, pertencente à Unilever e vendida em todo o planeta concorrendo com marcas locais. Agrega-se, aqui, a ideia de "cultura local”, vinculada à valorização de práticas alimentares do passado que estariam em risco de desaparecimento em função da entrada dos alimentos produzidos para o global. A palavra "genuíno" deriva etimologicamente do latim genuinus que significa "natural, não adquirido". Para o dicionário, genuíno diz respeito aquilo que é puro, sem mistura nem alteração ou que é autêntico. Já a palavra local deriva do latim locus, que diz respeito ao lugar. Desta forma, tais passagens suscitam grande inquietação, afinal, o que é uma cultura alimentar genuína de um lugar?

A geógrafa Doreen Massey (2005) explica que tal forma de conceber as culturas e os lugares têm suas raízes num certo modo através da qual a história da Modernidade vem sendo contada e através da qual desenvolveu-se uma compreensão hegemônica da natureza do espaço e da relação entre o espaço e a sociedade. Por algum tempo, a noção idealizada de lugares habitados por comunidades coerentes e homogêneas, totalidades estáticas e autocontidas perpetuou-se nas Ciências Sociais como um todo. Para a autora, uma das consequências dessa forma concepção da natureza do espaço na Modernidade traduz-se num suposto isomorfismo entre "espaço e lugar" e "sociedade e cultura". Nessa perspectiva, espaço e sociedade formavam um mapa recíproco em que comunidades locais traziam suas "culturas genuínas” contidas em seus respectivos lugares/locais, bem como, nações possuíam seus Estados-nação, ambas com delimitações espaciais e fronteiras internamente coerentes. Trata-se de uma forma de imaginar o espaço - uma imaginação geográfica - constituinte daquilo que se tornaria um projeto para "organizar" o espaço global. E, através dessa imaginação do espaço como regionalizado/dividido, o projeto particular e altamente político da forma Estado-nação pode ser legitimado e generalizado pelo mundo, como forma de progresso ${ }^{9}$ incontornável das sociedades.

9 As principais implicações dessa noção são as seguintes: a) o curso dos eventos (naturais e históricos) constitui uma série unilinear; b) cada termo desta série é necessário no sentido de não poder ser diferente do que é; c) cada termo da série realiza um incremento de valor sobre o precedente; d) qualquer regressão é aparente e constitui a condição de um P. maior. (ABBAGNANO, 2007) 
A autora ressalta que essa maneira implícita de compreensão do espaço tem repercutido sobre a forma da "saudade" de uma eventual "coerência do lugar”, refletindo-se em nacionalismos que frequentemente buscam recuperar heranças essencializadas. Nessa leitura, os lugares/locais e as práticas alimentares tradicionais a eles associadas são foco de uma forma de escapismo romantizado da atividade real do mundo. "Enquanto o tempo é visto como movimento e progresso, o espaço ou lugar é equiparado ao imobilismo e reação" (MASSEY, 2000, p. 181), ou seja, os lugares/locais de alimentação representariam um receptáculo material onde seria factível perpetuar um conjunto de práticas alimentares do pretérito, tornando as "culturas alimentares genuínas e tradicionais" imortalizada.

No entanto, como reforça a autora, o que dá ao lugar/local sua especificidade não é uma história longa e essencializada, mas o fato de que estes se constroem a partir de uma constelação particular de relações socioculturais, que se encontram e se entrelaçam num locus particular. Assim, para pensarmos os lugares/locais na sua história e, principalmente, na atualidade, deveríamos partir da noção que estes são constructos extrovertidos, que existem necessariamente mediante suas ligações com o mundo mais amplo, integrando constitutivamente o global e local. Sob essa ótica, qualquer explicação adequada de um lugar deveria colocar o local em seu contexto mais amplo.

Recomendações para que a procedência dos alimentos adequados para o consumo seja oriunda de mercados locais em prol da saúde dos sujeitos e do ambiente minimizam, tanto a complexa trama envolvida na produção, distribuição e consumo de alimentos no cenário global e os atuais desdobramentos desse processo nos grandes centros urbanos e nos campos industrializados do Brasil, quanto as transformações nas práticas alimentares incorporadas através de atualizações adaptativas ${ }^{10}$ diante da emergência desses novos contextos. ${ }^{11}$ Tal formulação opera no sentido de ofuscar a dinamicidade

10 Para Carvalho (2011) diferentes estilos alimentares sofrem as mesmas pressões condicionantes da globalização, nas condições de vida e de trabalho, nos modos de ser, de sentir e de pensar, de imaginar dos sujeitos, atualizando suas práticas de modo adaptativo. A autora defende com exemplos que tanto as práticas como os termos "fastfood" e "natural" sofrem ressignificações, adaptando-se a contextos sociais como estratégia de convivência e de sobrevivência social.

11 O cafezinho e o pão de queijo "mineiro" vendidos nos engarrafamentos das Linhas Vermelha e Amarela do Rio de Janeiro são bons exemplos dessa apropriação de marca simbólica de um alimento 'genuina- 
própria da vida humana, daquilo que compreendemos como cultura e dos novos, antigos - ou que for da humanidade - lugares de alimentação.

Para a incorporação de uma visão dinâmica e articulada dos lugares de vida das pessoas, Massey (2000) propõe que nos distanciemos de concepções que os compreendam como "materialidade estática delimitada". Os lugares não devem ter fronteiras no sentido de divisões demarcatórias. Eventualmente, lugares podem ser delimitados para estudos, mas não para conceituação de um lugar em si. Sua definição não deve ser feita por meio da simples contraposição ao exterior, seja uma rua, uma região ou um continente. Para autora, apenas poderemos vislumbrar a compreensão das múltiplas e dinâmicas socioculturais imbricadas em um lugar se os pensarmos como momentos articulados em uma rede de relações de entendimentos sociais extralocais.

Ao não imaginarmos os lugares em seu contexto mais amplo, a ideia de comunidades "locais" nos parece a cada dia mais frágil e insustentável, uma vez que podemos visitar outros países e encontrar os mesmos restaurantes e produtos alimentares que frequentemente temos disponíveis em nosso bairro ou quando podemos comer comida japonesa ou mexicana em qualquer shopping center no Brasil. É também curioso percebemos que, ainda que seja possível comer sushi em um shopping brasileiro ou japonês, cada um de nós poderá ter experiências muito diferentes, únicas, singulares nesses lugares aparentemente iguais. Do mesmo modo, nas gôndolas dos supermercados podemos encontrar massas italianas, azeites portugueses, queijos franceses ou vinhos de diversas nacionalidades com um preço menor que o de um concorrente local. Assim também, muitos produtos locais fazem parte da cadeia produtiva de grandes atores globais ou agem segundo a mesma ótica e utilizam as mesmas estratégias. Há, ainda, alimentos industrializados localmente produzidos que correspondem a versões de segunda linha ou simulacros de produtos originários das grandes empresas internacionais, carreando ambos os mesmos problemas relacionados a excessos de sal, açúcar e/ou gorduras em sua composição. Consumir quaisquer desses alimentos - sushi no restaurante a quilo, azeite "tipo" português, biscoito “isopor”, refrigerante imitação etc. - pode significar a incorporação de

mente local e imaginariamente fixado na cultura tradicional', cujo simulacro é comercializado em contexto totalmente fora do habitual. 
signos absolutamente particulares, de distinções únicas e em expressões das mais diversas intensidades em relação a pratos considerados "genuinamente tradicionais” e próprios da "cultura alimentar local”. Assim, ressaltamos que é necessário conceber os lugares de alimentação não como estáticos ou(e) como simples construções materiais, mas como sempre dinâmicos lugares-encontro, entre pessoas e comidas, em permanente transformação, abertos a constante ressignificações e a múltiplos sentidos.

Diante da complexidade do assunto, evidentemente, a materialidade também desempenha o papel de suporte de mensagens e de símbolos. Desta forma, recorremos ao tema das formas espaciais simbólicas sistematizado pelo geógrafo brasileiro Roberto Lobato Corrêa. Para nós, estudar os símbolos em sua dimensão espacial, constitui um exercício cuja finalidade é dar visibilidade a um importante aspecto da ação humana, marcada não somente por uma perspectiva econômica ou racional, mas também pelo ato de simbolizar no e a partir do espaço. Para Santos (1985), a forma é o aspecto visível de um objeto no espaço, referindo-se ao arranjo ordenado de objetos. Nesse seguimento, Corrêa (2007) argumenta que estas formas espaciais seriam também simbólicas uma vez que carregam representações da realidade, resultantes de complexos processos pelos quais os significados são produzidos e comunicados entre pessoas de um mesmo grupo social.

Partindo da corrente construtivista de interpretação dos signos, Roberto Lobato Corrêa considera que os significados são construídos a partir das experiências daqueles que interpretam as formas simbólicas. Assim, as formas espaciais simbólicas estão sujeitas a interpretações distintas, caracterizando-se por uma instabilidade de significados, ou seja, por uma polivocalidade. Resgatando os escritos de Panovsky (2004) - que debruça-se sobre o estudo da Iconografia - o autor destaca que os significados das obras de arte são construídos em três níveis: um primeiro que opera na identificação das formas puras, reconhecidas como portadoras de um significado primário; um segundo nível onde produzem-se significados secundários e/ ou convencionais, onde podem estabelecer-se imagens, histórias e alegorias; e um terceiro nível, no qual, finalmente, produzem-se um significado profundo, intrínseco, no qual se revelam por exemplo a atitude básica de um período histórico, de uma classe social, ou mesmo de uma filosofia. $\mathrm{O}$ último nível corresponde assim a Iconologia, ou seja, um método interpretativo, aberto e construtivista. 
As relações entre formas simbólicas e espaço são complexas e caracterizam-se por uma "mão dupla” pois, ao passo que se realizam enquanto tais em razão de sua localização, as próprias localizações são marcadas pela presença das formas simbólicas. Corrêa (2007) nos chama a atenção para o fato que as políticas locacionais das formas simbólicas derivam do desejo de que elas cumpram eficientemente o papel que delas esperam aqueles que as conceberam. Tal política envolve as "dimensões absoluta e relativa do espaço" que abrangem a localização absoluta, a localização relativa e a localização relacional das formas simbólicas. (CORRÊA, 2007, p. 13)

A localização absoluta de uma forma espacial simbólica designa o sítio onde ocorre um dado evento considerado significativo ou que se deseja transformar em local de celebração ou contestação por apresentar um potencial positivo para este fim. No que tange a alimentação, podemos destacar como exemplo de localização absoluta de uma forma espacial simbólica, um restaurante à beira mar cujo prestígio esteja associado à sua localização, como o muro do Bar da Urca. ${ }^{12}$

A localização relativa de uma forma espacial simbólica diz respeito à visibilidade, mas, sobretudo, a acessibilidade face a toda cidade ou espaço regional ou nacional. Esta acessibilidade é um dos meios mais importantes para que as formas espaciais simbólicas possam transmitir as mensagens que delas se espera. Um ponto de venda de alimentos, estrategicamente posicionado em um local que o forneça ampla visibilidade e acesso a um público variado. Como exemplo, podemos registrar o caso de uma marca de biscoitos que monta um estande em um evento internacional como o Rock in Rio, que recebe visitantes de todas as partes do mundo. $\mathrm{O}$ estande constitui-se uma forma espacial simbólica que usufrui de uma localização relativa, isto é relacionada ao evento e a rede de fluxos internacionais que imbrica.

Finalmente, as formas espaciais simbólicas apresentam uma localização relacional, isto é, quando localizadas em relação a outras formas simbólicas que denotam interesses divergentes, um conjunto de valores que é referenciado a um dado espaço, ao qual se opõe outro espaço. Uma barraquinha

12 O Bar Urca é um restaurante especializado nas cozinhas brasileira e portuguesa. Os frequentadores o transformaram em espécie de point carioca democrático, muito disputado no verão por locais e turistas, pois serve também cerveja e petiscos de forma bastante descontraída: na mureta da Urca - um muro baixo ao lado de uma calçada com vista para a Baía de Guanabara e seus atrativos, como a praia da Urca, o Corcovado, os bondinhos do Pão de Açúcar. 
de pipoca localizada em frente a um antigo cinema de rua beneficia-se de sua posição relacional pois a pipoca vendida no grande estabelecimento não assume o mesmo valor simbólico que a pipoca vendida pelo pipoqueiro em sua "tradicional" carrocinha. O Mate Leão, é outro exemplo de produto tipicamente carioca, que pertence à Coca Cola. O valor simbólico da "marca carioca" se torna apenas um valor agregado à marca global. É bastante importante bem como interessante notar como o valor simbólico do alimento se entrelaça ao valor simbólico das formas espaciais.

É pertinente ressaltarmos também para uma eventual política de escala na qual as dimensões das formas espaciais simbólicas são concebidas. Esta também possui dimensões absolutas ou relacionais. A dimensão absoluta da escala diz respeito ao elemento físico da forma simbólica espacial, ou seja, expressa uma área, volume ou altura às quais se associam a magnitude e o prestígio. Um grande letreiro de uma famosa rede de fast food em uma via de circulação movimentada da cidade, pode indicar que aquela localização abriga uma comida mais saborosa; placas frontais em restaurantes, barraquinhas, quiosques populares tendem ultimamente a assumir tamanhos bastante grandes, estabelecendo em algumas circunstâncias verdadeiras disputas entre si, cada um, lado a lado, afixando painéis cada vez maiores uns em relação aos outros, independentemente do tamanho do ponto comercial; isso como quem tenta garantir mais visibilidade e distinção ao seu negócio em função do tamanho da peça publicitária instalada.

Já a dimensão relacional da escala, diz respeito a comparação com outras formas simbólicas espaciais caracterizadas pelas dimensões físicas imponentes. Hipoteticamente podemos imaginar dois restaurantes concorrentes que disputam território ${ }^{13}$ e sua sobrevivência utilizando como recurso reconfigurações sistemáticas de suas formas espaciais através de reformas. O restaurante mais amplo, com melhor comodidade e conforto para seus clientes irá se perpertuar na localização por transmitir aos seus frequentadores a ideia, o significado de que estes consomem uma comida refinada. Cabe ressaltar que as duas dimensões de escala, absoluta e relacional, associam-se a ideia de poder e a superioridade.

13 "O território, nessa perspectiva, é um espaço onde se projetou um trabalho, seja energia e informação, e que por consequência, revela relações marcadas pelo poder. O espaço é a 'prisão original', o território é a prisão que os homens constroem para si”. (RAFFESTIN, 1993, p. 143-144) 
Assim, as formas simbólicas espaciais são concebidas segundo seus idealizadores para realizar diversas funções. Dentre estas podemos destacar a glorificação do passado, como no caso de restaurantes que sistematicamente adotam layouts que reconstroem lugares da nossa memória como "a cozinha da avó" ou "os anos 80"; ou, ao contrário sugerir a chegada do futuro. Por esta via, diferentemente da primeira, a finalidade do arranjo espacial e a exposição de certos objetos é sugerir aos frequentadores a chegada inevitável do novo. ${ }^{14}$ Nessa intenção, conformam-se espaços que aderem a todos tipos de tecnologia, como no caso de supermercados que dispensam a mão de obra humana passando a fazer uso de caixas automáticos ou quando por exemplo garçons de restaurante utilizam computadores de mão para efetuar pedidos em mesas. Nestes espaços deslocamo-nos para um futuro não realístico, contido apenas nos "limites" do estabelecimento.

As formas espaciais simbólicas constituem importantes elementos no processo de criação e manutenção da identidade, seja étnica, racial, social, religiosa e, ressaltamos, a identidade de lugar. Diante de intensos movimentos de ambientalização de movimentos sociais ${ }^{15}$ e a aparição de estilos de vida associados, ambos voltados para adoção de valores como o de proteção animal e ambiental, assistimos sistematicamente a incorporação desses valores no arranjo espacial a partir de geossímbolos associados nos quais, por exemplo, empresas do ramo alimentício conformam seus espaços de venda de produtos, imprimindo sobre estes símbolos como as cores verde e marrom, ou mesmo a utilização de adornos com formatos de animais e plantas, ajudando a conformar a identidade espaciais e alimentares das pessoas que frequentam esses locais.

Em diálogo com Edward Relph e Joél Bonnemaison, o geógrafo Roberto Lobato Corrêa (2010) caracteriza as formas simbólicas espaciais enquanto geossímbolos, ou seja, marcas identitárias que individualizam certa porção

\footnotetext{
14 Neste caso, o fenômeno das antigas barbearias transformadas em barbershops que vendem cervejas, roupas, serviços, tratamentos estéticos e produtos cosméticos com estilo vintage é um bom exemplo.

15 Henri Acselrad explora a temática em questão em seu artigo "Ambientalização das lutas sociais - o caso do movimento por justiça ambiental”. Para o autor, é por meio do processo que ele conceitua como ambientalização que novos fenômenos vão sendo construídos e expostos à esfera pública, assim como velhos fenômenos são renomeados como "ambientais", nos quais um esforço de unificação engloba-os sob a chancela da "proteção ao meio ambiente"S. O autor destaca que disputas de legitimidade se instauram, concomitantemente, na busca de caracterizar as diferentes práticas como ambientalmente benignas ou danosas.
} 
do espaço. Nesse sentido a toponímia - a nomeação de bairros, ruas, cidades, restaurantes, shoppings, lojas, - também se caracteriza como um geossímbolo, uma forma simbólica de identificar um logradouro público atribuindo-lhe um significado que pode tanto valorizar ou estigmatizar o lugar referenciado. As marcas LAPA ou Favela, por exemplo, tanto podem ser estigmatizadoras como propulsoras de vendas de produtos na indústria do vestuário ou do entretenimento. Para Corrêa (2010), nomear uma localidade constitui uma forma de apropriação do espaço, impregnando-o de significado associado ao nome. A toponímia pode ser vista como a resultante da combinação entre linguagem, política territorial e identidade.

No entanto, como ressaltado anteriormente, reconhecemos a existência de uma polivocalidade das formas simbólicas espaciais, ou seja, em contrapartida a interpretação oficial articuladas pelas elites produtoras de tais formas, existem interpretações populares mais compartilhadas, ou mesmo individuais que podem se caracterizar pela contestação dos valores pretendidos por seus idealizadores. Assim, reconhecemos que pessoas tecem ligações com seus lugares. Porém, mesmo onde existe uma conexão entre "a comunidade" e o "lugar” não seria pertinente reivindicar um sentido único para estas designações, uma vez que pessoas ocupam diferentes posições no interior de qualquer comunidade, atribuindo assim sentidos diferentes aos lugares. As camisetas vendidas pela internet (em todo o país e no mundo todo) com citações às praias do Rio como Ipanema, Leblon, Grumari, Prainha ou Copacabana demonstram essa apropriação do lugar simbólico. Roupas e assessórios, de um lado, para corpos das classes altas disponíveis para aquisição nas lojas situadas em shoppings, os mais sofisticados. De outro lado, vestuário para corpos "ostentação", peças comercializadas inclusive entre os setores mais empobrecidos das megalópoles brasileiras. Assim também, os sentidos das festas marcadas por comidas e bebidas requintadas podem também ter realização nos bairros nobres ou, ao lado da fome, conferindo distinção no seio das comunidades periféricas, na multiplicidade de identidades que as habita, na heterogeneidade material e representacional que as sustenta, na extremada violência física e simbólica que atravessa, vincula e separa a miséria e a riqueza humanas; estas que são intimamente entrelaçadas em cada lugar no negócio internacional da comida, da terra, dos produtos químicos, dos medicamentos, das armas, das drogas, das commodities, do mercado financeiro... 
O itinerário das pessoas pelo lugar, seus refúgios favoritos e as conexões que realizam entre este o resto do mundo - fisicamente, por telefone, por e-mail, por compras ou pela imaginação - variam muito. "Se se reconhece que as pessoas têm identidades múltiplas, pode-se dizer a mesma coisa dos lugares. Ademais, essas identidades múltiplas ${ }^{16}$ podem ser uma fonte de riqueza ou de conflito”. (MASSEY, 2000, p. 183) Dessa forma, se as identidades, tanto as especificamente espaciais quanto as outras, são, de fato construídas relacionalmente, então isto coloca a questão da geografia dessas relações de construção e é a partir dessa perspectiva que se torna possível uma construção alternativa dos sentidos dos lugares. Assim, ressaltamos, com Massey (2000, p. 184) a necessidade das abordagens sobre o espaço e sobre os lugares preencherem suas visões com todas as "[...] experiências da compressão tempo-espaço”, pois o que está acontecendo “[...] é que a geografia das relações sociais está mudando”.

\section{REFERÊNCIAS}

ABBAGNANO, N. Dicionário de filosofia. São Paulo: Martins Fontes, 2007.

ALENCASTRO, I.; VARGAS, E. P.; FERREIRA, F. R. et al. Você tem um rosto lindo, nunca pensou em fazer dieta?. In: PRADO, S. D.; FERREIRA, F. R.; VARGAS, E. P. et al (org.). Cinema e Comensalidade 2. Curitiba: CRV, 2017. p. 161-180.

ARNAIZ, M. G. Mudanças econômicas e socioculturais e o sistema alimentar: em direção a uma nova ordem alimentar?. In: CANESQUI, A. M.; GARCIA, R. W. D. Antropologia e nutrição: um diálogo possível. Rio de Janeiro: Editora Fiocruz, 2005. p. 147-164.

AZEVEDO, E. Alimentação, sociedade e cultura: temas contemporâneos. Sociologias, Porto Alegre, v. 44, n. 19, p. 276-307, 2017.

BARCELLOS, D. M. N.; COSTA, M. F.; CARVALHO, M. C. V. S. et al. Identidade Alimentar: o discurso do saboroso e saudável em anúncios publicitários. In: PRADO, S. D. (org.). Alimentação e consumo de tecnologias. Curitiba: 2015. p. 177-201.

BRASIL. Lei $\mathrm{n}^{\circ} 11.326$, de 24 de julho de 2006. Estabelece as diretrizes para a formulação da Política da Agricultura Familiar e Empreendimentos Familiares Rurais. Diário Oficial da União: seção 1, Brasília, DF, 25 jul. 2006.

16 Neste sentido, consultar Hall (1998). No que tange a alimentação e a pluralização da vida social contemporânea, com ampliação das identidades alimentares possíveis assumidas pelos indivíduos, consultar obra de Barcellos em 2015, Identidade Alimentar: o discurso do saboroso e do saudável em anúncios publicitários. 
CARVALHO, M. C. V. S.; LUZ, M. T. Simbolismo sobre o "natural” na alimentação. Ciência e Saúde Coletiva, Rio de Janeiro, v. 16, n. 1, p. 147-154, 2001.

CORRÊA, R. L. Formas simbólicas e espaço: algumas considerações. Aurora Geography Journal, Guimarães, v. 1, p. 11-19, 2007.

CORREAA, R. L. Temas e Caminhos da Geografia Cultural. In: ROSENDAHL, Z.; CORREAA, R. L. (org.). Temas e Caminhos da Geografia Cultural. Rio de Janeiro: Ed. UERJ, 2010. p. 11-36.

DIAS, J. et al. Comida, território e identidade cultural: em busca de sentido para uma interpretação do Brasil. SCIENTIARUM HISTÓRIA, 7., 2014, Rio de Janeiro. Anais [...]. Rio de Janeiro: Scientiarum História, 2014. Não paginado.

EMBRAPA. Soja em números: safra. EMBRAPA, Brasília, DF, 2019. Disponível em: https://www.embrapa.br/soja/cultivos/sojal/dados-economicos\&gt. Acesso em: 27 set. 2019 .

FISCHLER, C. El (h)ominívoro: el gusto, la cocina y el cuerpo. Barcelona: Anagrama, 2015.

HALL, S. A identidade cultural na pós-modernidade. Rio de Janeiro: DP\&A, 1998.

IBGE. Sinopse do Censo Demográfico 2010. IBGE, Brasília, DF, 2010. Disponível em: https://censo2010.ibge.gov.br/sinopse/index.php?dados=10\&amp;uf=00\&gt. Acesso em: 25 set. 2019

INCRA. Atlas Fundiário Brasileiro. Brasília, DF: INCRA, 2004.

MASSEY, D. Pelo Espaço: uma nova política da espacialidade. Rio de Janeiro: Bertrand Brasil, 2005.

MASSEY, D. Por um Sentido Global do Lugar. In: ARANTES, A. (org.). O espaço da diferença. São Paulo: Papirus, 2000.

MELHORES e Maiores: as 1.000 maiores empresas do Brasil. Revista Exame, [s. l.], 2017. Disponível em: https://exame.abril.com.br/\&gt. Acesso em: 5 fev. 2018. p. 176-185.

OSWALD, V. Alimentos mais caros e nas mãos de poucos: dez empresas dominam mercado global e dificultam reação à alta dos preços. O Globo, Rio de Janeiro, p. 32, 20, 2011.

PANOVSKY, E. Iconografia e Iconologia: uma introdução ao estudo da arte na renascença. In: PANOVSKY, E. Significados das Artes visuais. São Paulo: Perspectiva, 2004. p. 47-87.

PELLERANO, J. A. Embalados e prontos para comer: relações de consumo e incorporação de alimentos industrializados. 2014. Dissertação (Mestrado em Ciências Sociais) - Programa de Estudos Pós Graduados em Ciências Sociais, Pontifícia Universidade Católica de São Paulo, São Paulo, 2014. 
PONS, S. C. Olhares antropológicos sobre a alimentação: pontos de partida teórico metodológicos para o estudo sociocultural da alimentação em um contexto de transformação. In: CANESQUI, A. M.; GARCIA, R. W. D. (org.). Antropologia e nutrição: um diálogo possível. Rio de Janeiro: Editora FIOCRUZ, 2005. p. 101-126.

PROENÇA, R. Alimentação e globalização: algumas reflexões. Ciência e Cultura, São Paulo, v. 62, n. 4, p. 43-47, 2010

RAFFESTIN, C. Por uma geografia do poder. São Paulo: Ática, 1993.

SANTOS, M. A Natureza do Espaço: técnica e tempo, razão e emoção. São Paulo: Universidade de São Paulo, 1996.

SANTOS, M. As metamorfoses do Espaço Habitado. São Paulo: Hucitec, 1998.

SANTOS, M. Espaço e Método. São Paulo: Nobel, 1985.

SANTOS, M. O retorno do território. In: SANTOS, M.; SILVEIRA, L.; SOUZA, A. (org.). Território: globalização e fragmentação. São Paulo: Hucitec: Anpur, 1994. p. 15-20.

SANTOS, M. Por uma Geografia nova: da crítica a geografia à uma geografia crítica. São Paulo: EdUSP, 1978.

SANTOS, M. Por uma outra Globalização: do pensamento único à consciência universal. Rio de janeiro: Record, 2000.

SÃO PAULO. Prefeitura de São Paulo, São Paulo, 2018. Demografia. Disponível em: https://www.prefeitura.sp.gov.br/cidade/secretarias/urbanismo/dados_estatisticos/ info_cidade/demografia/index.php?p=260265\&gt. Acesso em: 25 set. 2019

VIANA, R. M.; NEVES, A. S.; PRADO, S. D. et al. A racionalidade nutricional e sua influência na medicalização da comida no Brasil. Ciência e Saúde Coletiva, Rio de Janeiro, v. 22, n. 2, p. 447-456, 2017.

WORLD HEALTH ORGANIZATION. Food and Agriculture Organization of the United Nations. Preparation and use of food-based dietary guidelines: report of a joint Fao/WHo consultation nicosia. Cyprus: World Health Organization, 1996. Disponível em: www.fao.org/docrep/x0243e/x0243e00. Htm. Acesso em: 15 set. 2019. 



\section{LACTANCIA MATERNA, RED DE APOYO Y LA PENALIZACIÓN DE LA POBREZA}

\section{REFLEXIONES ETNOGRÁFICAS SOBRE UNA OPRESIÓN DE GÉNERO Y CLASE ${ }^{1}$}

ANA GRETEL ECHAZÚ BÖSCHEMEIER

LUCRECIA RAQUEL GRECO

\section{INTRODUCCIÓN: PRÁCTICAS DE MATERNAJE EN PLURAL}

El presente capítulo parte de la revisión crítica de materiales etnográficos producidos durante una investigación antropológica en una maternidad de la ciudad de Salta, Argentina, durante todo el año 2006. (ECHAZÚ-BÖSCHEMEIER, 2007) La misma tuvo como foco las prácticas destinadas a la promoción de la lactancia materna para mujeres-madres gestantes y puérperas de clase trabajadora llevadas adelante en un hospital público de la ciudad. En los materiales trabajados es posible observar cómo

1 El presente trabajo está basado en investigación etnográfica de esta autora, realizada en el marco del trabajo final de Licenciatura en Antropología, Universidad Nacional de Salta, Argentina. Parcialmente financiado por el Programa Nacional de Becas Universitarias del Ministerio de Educación de la Nación, Argentina. 
el discurso de la lactancia materna se impone como obligación corpórea y natural para las mujeres pobres y usuarias del sistema público de salud, que son moralmente penalizadas por el personal de salud si no llevan adelante una práctica de lactancia en los tiempos y maneras recomendados por los organismos internacionales como OMS y UNICEF. Como resultados observamos que, paradójicamente, tales discursos penalizadores subrayan la importancia de los vínculos sociales tejidos alrededor de las mujeres-madres en la construcción de una lactancia "exitosa".

Escribimos este texto a partir de dos subjetividades militantes, que han reflexionado académicamente sobre cuerpos, género, salud, derechos humanos y maternajes en contextos rurales, indígenas, ayahuasqueros, quilombolas y periféricos en diferentes experiencias de trabajo de campo entre Argentina, Brasil y Perú en los últimos veinte años. (BÖSCHEMEIER, 2007; ECHAZÚ-BÖSCHEMEIER, 2010; ECHAZÚ-BÖSCHEMEIER; MARTON, 2010; GRECO; OJEDA, 2019) Las dos nos comprendemos como mujeres habitantes de la frontera (ANZALDÚA, 1987) nos situamos étnico-racialmente como blancas mestizas, somos madres biológicas de cinco crías en total y hemos amamantado de forma prolongada a nuestres ${ }^{2}$ hijes - dos de los cuales son mellizos. A partir de prácticas de maternaje vividas en la frontera como lugar de habla (RIBEIRO, 2017), un lugar que ha sido incesantemente objetivado por la medicina, la moral, los medios de comunicación y las políticas públicas, es que tejemos esta reflexión. Admitimos nuestra fascinación por las potencialidades de la lactancia materna, sin embargo nos preocupa la instrumentalización de esta práctica al servicio de pautas biopolíticas, higienizadoras y disciplinadoras de los cuerpos femeninos, pobres, no-blancos, con deficiencias y migrantes y de todos aquellos cuerpos vulnerados y subalternizados por los múltiples ejes de opresión que estructuran nuestra sociedad.

La maternidad ha sido un tema conflictivo en el marco de los feminismos hegemónicos blancos y occidentales, desde los cuales se la ha considerado una de las máximas formas de opresión sobre las mujeres, que las relegaría exclusivamente al ámbito doméstico, normalizando su vida y subjetividades.

2 Partimos de discusiones globales sobre el lenguaje como forma de saber-poder para posicionarnos a favor del lenguaje inclusivo. En nuestra estrategia de escritura, el mismo se efectiviza a partir de la extensión al plural del género neutro de la lengua española y, de esta manera, obliterando el masculino genérico y universalizante que prevalece en la norma, tanto culta como popular, de nuestra lengua. (QUINTERO, 2019) 
Sin embargo, feministas africanas, diaspóricas, negras e indígenas (MUÑOZ, 2019) han llamado la atención sobre la importancia de repensar las prácticas de maternaje en el contexto de los diversos posicionamientos de raza, clase, edad y nacionalidad situados a partir de otros centros distintos del la familia burguesa y que habilitan la problematización de los múltiples modos de maternar y cuidar que se encuentran en los márgenes y fuera de la maternidad burguesa. ${ }^{3}$ Siguiendo esta línea crítica, nuestras reflexiones no se formulan en los términos de una Maternidad en cuanto institución, modelo e ideal burgués, sino a partir de prácticas de maternaje, entendidas como experiencias vividas en contexto de cuidado materno, donde se cuestionan los ideales prescriptivos de la familia nuclear, heteronormativa y reproductiva en dirección a otras posibles formas de existencia. (RICH, 1986) Así, un estudio sobre maternajes es también una indagación respecto a las múltiples formas de cuidado que trascienden la díada madre-hije(s) institucionalizada por la mirada médica en la Europa Occidental de los albores del siglo XIX (BADINTER, 1981) y que tendemos a reproducir en las políticas públicas de salud accionadas desde los estados del Sur global. (BIDEGAIN; CALDERÓN, 2018; MUÑOZ, 2019)

A continuación, presentaremos los puntos principales del abordaje teórico referenciado, constituido en dos subsecciones: a) cuerpos lactantes y biopolíticas; b) la díada madre-hije y la comensalidad compulsiva. Estas aproximaciones atravesaron el trabajo de campo etnográfico, siendo tensionadas permanentemente durante el proceso de construcción del campo. Ellas serán accionadas, más adelante, en el análisis de las narrativas particulares que emergieron de las etnografías realizadas.

\section{CUERPOS LACTANTES Y BIOPOLITICAS}

Las verdaderas madres admiten con alegría inefable el dar de mamar a sus hijitos.

(Otero, 1922)

3 Aun reconociendo la importancia de la cuestión racial, visible sobre todo a partir de la problematización en espejo de los casos de Brasil y Estados Unidos (CRENSHAW, 1989; MACHADO, 2010), y cuya importancia como variable estructurante de opresiones es imposible negar, hemos ponderado colocarla al margen en la revisión de este caso por no poseer suficiente material etnográfico ni un estado de la cuestión claro sobre indagaciones al nivel local en el NOA, para realizar las inferencias necesarias, levantando la pauta de la necesidad de su inclusión en el marco de futuros estudios. 
Apoyamos esta reflexión en las problematizaciones sobre la experiencia corporal femenina en el contexto de prácticas biopolíticas hospitalarias. La filósofa feminista Linda Martin Alcoff (1999) propone compatibilizar la centralidad epistemológica de la experiencia corporal con la crítica de su contenido ideológico, considerando el cuerpo desde el lugar de la experiencia y la percepción y no solamente desde los lugares del lenguaje y la textualidad. Podemos decir que el ámbito de la lactancia materna, al involucrar experiencias sobre un momento fisiológico particular, "chorrea" sentidos que inundan la experiencia de corporalidades diversas. Esta diversidad fenomenológica se despliega en un mundo desigual y plagado de violencias, siendo dentro de este marco que se construyen los fenómenos fluidos de la percepción y atención, así como los propios procesos fisiológicos.

Judith Butler (1999), en sus búsquedas por una epistemología de los cuerpos abyectos dentro de políticas de lo habitable, reflexiona sobre dos dimensiones en torno a la precariedad de la vida: la que es intrínseca a la vida en sí misma y a nuestra existencia como seres interdependientes y, frente a determinadas circunstancias, más o menos dependientes (situades en la infancia, enfermedad, deficiencia, vejez, etc.); y aquella otra dimensión, estructurante, de las vidas colocadas en situación de precariedad debido a factores socioeconómicos, políticos o culturales. Ambas dimensiones están relacionadas pero no podrían reducirse la una a la otra. En lo que hace a la precariedad de la vida, la díada madre-hije en la primera infancia se inscribe en una condición intrínsecamente frágil en tanto que precisa de protección, apoyo, tiempos y espacios propicios para existir. En lo que respecta a la condición de precariedad en la que esta relación puede situarse, observamos que las mujeres-madres y sus hijes localizades en los más altos grados de vulnerabilidad social poseen redes de apoyo que tienden a ser más lábiles, sobre todo en lo que respecta a apoyos estructurantes en términos de acceso a derechos o recursos.

En lo que hace a la dimensión propiamente corporal en el contexto de esta precariedad de la vida, entendemos que los cuerpos de madre-hije(s) "importan" y nutren nuestra reflexión, tanto como agentes activos de la gestión y experiencia carnal del vínculo de lactancia, así como en cuanto sujetos de las normas que se imponen sobre elles. Los cuerpos no son sustratos biológicos pasivos donde se imprimen normas sociales, sino partes constitutivas del ser en el mundo. (CSORDAS, 2011) En este sentido, 
consideramos los cuerpos en su especificidad concreta, pensando la biología como una materialidad abierta, conformada por un conjunto de tendencias y potencialidades infinitas. (GROSZ, 1994; GRECO; OJEDA, 2019) En el marco de contextos como los que estudiamos, los límites de lo biológico son forjados con la finalidad de legitimar discursos con peso de verdad por causa de su presunta "naturalidad". (FOUCAULT, 2008) En contextos colonizados del Sur global como lo es el noroeste argentino, las fuerzas del Estado actúan de forma particular: la biopolítica opera en espacios muy delimitados en territorios cuya función principal es, prioritariamente, represiva y violenta - esto es, necropolítica. (MBEMBE, 2006) Con el movimiento pendular de los regímenes de Bienestar social, la mirada sobre madres y sus hijes biológiques ha fomentado un "hacer vivir" centrado en los cuerpos infantiles y maternos, colocando a las políticas de salud orientadas a la díada madre-hije como potentes dispositivos biopolíticos proyectados hacia la población.

Las prácticas de lactancia materna estimuladas en el Nuevo Hospital El Milagro colocan en el centro del debate la biopolítica y la comensalidad como dos formas normativas de tratamiento de los cuerpos que se encuentran solapadas: la lactancia regula los cuerpos de las mujeres en cuanto reproductoras, cuidadoras y seres nutricios. (BIDEGAIN; CALDERÓN, 2018) La paradoja del discurso sobre el carácter instintivo de la lactancia materna en los ámbitos que estudiamos es que esta deba ser enseñada, transmitida y pedagogizada. Asimismo, en la naturalización se ejerce la responsabilización exclusiva de la madre biológica, entendiendo la naturaleza como una regla fija que, de forma poco inocente, sexifica y generifica la materia viva. (BUTLER, 1999)

\section{LA DIAADA MADRE-HIJE Y LA COMENSALIDAD COMPULSIVA}

La biopolítica que reduce a las mujeres al papel de reproductoras y seres nutricios precisa, para poder existir en el espacio-tiempo, de prácticas eminentemente violentas. Para la antropóloga francesa Françoise Héritier (1996), puede comprenderse como violencia aquel abanico de conductas que ostentan una restricción de naturaleza física o psíquica susceptible de llevar al terror, al desplazamiento, a la infelicidad, al sufrimiento o a la muerte de un ser animado. Hablar de violencia es forzar, directa o 
indirectamente, una voluntad, una libertad real o supuesta. Las conductas que, con frecuencia, quedan ocultas y no identificamos como tales pueden inscribirse dentro de lo que Pierre Bourdieu (2000) definió como violencia simbólica. En la etnografía sobre prácticas de lactancia materna en ambiente hospitalario, identificamos que la violencia simbólica atraviesa, de forma constitutiva, las pedagogías volcadas al estímulo de esta práctica colocada como "lo ideal y natural".

En el presente estudio ponderamos la importancia de una apropiación crítica de la idea de comensalidad, enfatizando los significados sociales del acto de comer en relación con la dimensión del poder. Amamantar puede ser comprendido como un acto de comensalidad, donde se produce una relación entre humanes mediada por un alimento: la leche. (VAN ESTERIK, 2002) En el tiempo y espacio, la práctica ha estado ligada a otras sujetas sociales que no eran exclusivamente las madres biológicas de les niñes, hayan sido éstas amas de leche, o comadres vinculadas por "lazos de leche". (ECHAZÚ-BÖSCHEMEIER, 2014) Así, en un marco liberal, cuanto más se enfatiza la vinculación de una madre biológica a su(s) hije(s), más desdibujada aparece la comensalidad de la lactancia, que de un acto social pasa a asumirse como "natural”. En adición, el pecho femenino aparece como un aspecto tabú de la lactancia en lugares públicos en innúmeros lugares, colaborando así la lactancia en lugares específicos para tales fines con la invisibilización de la lactancia como acto social. De esta manera, hemos decidido definir a las políticas de lactancia materna impulsadas por agentes que ignoran los deseos y necesidades maternos y las redes de comensalidad posibles para los actos de maternar como actos que conforman lógicas de "comensalidad compulsiva”. Las mismas reducen a las mujeres a sujetas con un instinto amamantador, y las colocan como responsables automáticas de la práctica de lactancia. Así es como la lactancia se torna, ineludiblemente, lactancia materna, y así es como el mito del instinto materno se manifiesta, en la comensalidad compulsiva de la lactancia, como una forma de opresión de las subjetividades femeninas.

Nos interesa también explorar la dimensión de la comensalidad en lactancia observando cómo ésta opera en función de las posiciones sociales en perspectiva interseccional. (CRENSHAW, 1989) En Europa occidental, varios estudios focalizaron la constitución de los ideales de maternidad burguesa y la gravitación de los maternajes de clases populares en torno a 
éste, sometiendo a las mujeres de clases populares a una explotación aún más intensa, donde al modelo doméstico de la madre abnegada se le suman las exigencias del trabajo, muchas veces informal, fuera de casa. (BADINTER, 1981; DONZELOT, 1990) En este diseño diferenciado de lógicas por clase, a las mujeres de estratos medios y altos ha correspondido la posibilidad de elegir entre opciones de alimento y comensalidad, esto es, entre lactancia materna y alimentación por fórmula, mientras que las mujeres de clases populares - quienes son justamente aquellas que poseen una menor posibilidad de entrega exclusiva a lo doméstico, deben salir de casa por más horas y trabajan en regímenes de mayor precariedad que no admiten la presencia de niñes en los horarios de trabajo, (BIDEGAIN; CALDERÓN, 2018) entre otras condiciones estructurantes de la vida - son las principales destinatarias del mensaje estatal de promoción de la lactancia materna. Por su posición periférica, indígena andina y fronteriza, constatamos que en la provincia de Salta las líneas de clase se endurecen crecientemente a partir de la ascensión de lógicas predominantemente necropolíticas (MBEMBE, 2006) y que se orientan a la eliminación de cuerpos considerados no-humanos o abyectos a partir de la reproducción de estructuras racistas, coloniales y capitalistas. Particularmente en la ciudad de Salta, es posible identificar dos sistemas paralelos: uno, de producción de la pobreza y la marginalidad (LEGUIZAMÓN, 2010), que potencia la muerte y encarcelamiento de jóvenes pobres, especialmente no-blancos, y otro, que fortalece la vida como potencia orientada hacia el Estado en políticas de preservación de la díada madre-hije. ${ }^{4}$

\section{METODOLOGIAS Y PRESENTACIÓN DEL CASO}

En este apartado, realizamos una introducción sistemática a la metodología utilizada para este estudio y presentaremos el caso, analizando de forma crítica y reflexiva algunas narrativas que emergieron del trabajo de campo que cobran especial sentido a la luz de la discusión propuesta. De esta manera, avanzaremos en el análisis de: a) las redes de apoyo; b)

4 En otro lugar (ECHAZÚ-BÖSCHEMEIER, 2007), ha sido estudiado a partir de fuentes históricas locales cómo fue que el cuerpo de las mujeres pobres se constituyó como objeto de normalización por parte del sistema público de salud en el norte argentino, induciendo prioritariamente al disciplinamiento de grupos populares. 
las normas institucionales como dispositivos biopolíticos y, finalmente; c) la lactancia materna en perspectiva interseccional. Esta parte del trabajo se constituye a partir del tensionamiento entre nuestro abordaje teórico, la metodología utilizada y la discusión de los resultados que emergieron del campo.

El presente texto se basa en una investigación etnográfica orientada por cuestionamientos propios de la antropología de la salud (LANGDON; WIIK, 2010), con foco en los abordajes dentro de los servicios de salud (FLEISCHER; FERREIRA, 2014) realizada en el marco de la tesis de una de las autoras dentro de la carrera de Licenciatura en Antropología Universidad Nacional de Salta, Argentina. El trabajo de campo fue realizado por dentro y fuera del Nuevo Hospital El Milagro, una institución hospitalaria durante todo el año 2006. Este hospital es referencia en términos de cantidad y calidad de atenciones ${ }^{5}$ en el área de partos institucionales en el sistema público de salud de la provincia. En entrevistas realizadas en plazas, parques y cafés cercanos al hospital o a los barrios donde las entrevistadas habitaban, fue posible acompañar aspectos propios de la cotidianidad de las mujeres. En total, se realizaron doce instancias de observación participante en reuniones grupales y fueron quince las personas entrevistadas, siendo de ellas siete mujeres-madres (contando promotoras de lactancia, madres voluntarias que ya habían pasado por experiencias de parto en ese hospital) y seis profesionales de la salud, respectivamente. En el caso de les profesionales de la salud, las entrevistas fueron realizadas, en su totalidad, dentro de la institución hospitalaria.

La elección de las mujeres-madres para esta investigación se realizó a base de redes de contactos y participación individual en espacios de promoción de la lactancia materna en Centros de Salud (Ciudad del Milagro y Vaqueros) y en el Nuevo Hospital El Milagro. La participación de una de las autoras de este texto como madre en un Grupo de Apoyo a la Lactancia del Nuevo Hospital El Milagro, fue el puntapié para impulsar esta investigación desde un lugar inicial de participante observante. (GOMES; MENEZES, 2008) A partir de estos encuentros, fueron contactadas las mujeres-madres

5 Fuente encontrado en año 2004 (2005), en Memoria Anual del Nuevo Hospital El Milagro en Salta, Argentina. 
que conversaron, dentro o fuera del hospital, respondiendo las preguntas de una guía previamente establecida.

Las entrevistas fueron realizadas según parámetros éticos vigentes de la investigación con seres humanos (OLIVEIRA, 2004) expresando de forma oral los objetivos de la investigación y bajo consentimiento de todes les entrevistades, tanto profesionales como usuaries del sistema de salud, respecto a los mismos. Los nombres de las personas entrevistadas fueron preservados. El estudio fue realizado con autorización del Departamento de Antropología de la Universidad Nacional de Salta bajo la dirección de la Lic. Norma Naharro y del Comité Gestor del Nuevo Hospital El Milagro bajo la supervisión de la médica María Zemczuk.

\section{EL CONTEXTO ETNOGRÁFICO}

En la ciudad de Salta en el año 2005, 21.454 mujeres de la periferia urbana dieron a luz en el Nuevo Hospital del Milagro. De los egresos totales, el 79,2 \% provenía de la ciudad de Salta (Memoria NHEM, 2006), siendo en gran parte de clases populares de la región Norte y Sur de la ciudad.

Este hospital presentaba un modelo de gestión de servicios privada subsidiado por el Estado, estructurándose a partir de una lógica corporativa interna y de una lógica de servicio público hacia el exterior. Al momento, la institución contaba con 475 empleados de los cuales, entre otras categorías, 107 eran profesionales de la medicina y 206 enfermeres. (ECHAZÚBÖSCHEMEIER, 2007)

En lo que hace a las dinámicas familiares de las mujeres usuarias, éstas formaban familias con, por lo general, más de dos hijes. Jefas de hogar en la práctica, cohabitaban con más de una generación en casa: era común la configuración de hijes, madres y abuelas, un esquema matrilineal de hecho, que aparecía como eminentemente patriarcal por derecho. Así, las familias aparecían en las estadísticas como siendo estructuradas alrededor de hombres - respondiendo a figuras masculinas que aparecían como "jefes de hogar" que, sin embargo, se encontraban ausentes. Trabajadores migrantes, pertenecientes al mercado informal, muchos de los compañeros de estas mujeres se sentían en el derecho de establecer más de un núcleo familiar en las diferentes localidades a las que sus trabajos los llevaban. Habitantes de conglomerados precarios en los márgenes, una parte importante de las 
mujeres que daban a luz en el Nuevo Hospital poseía escolaridad media incompleta, no contaba con plan de salud gremial o estatal y se manifestaba desempleada con empleos informales.

A partir del sexto mes de gestación, las mujeres eran invitadas a participar de "clases pre-parto" de promoción de la Lactancia Materna una vez por semana. Las charlas tenían lugar en un salón de reuniones del hospital destinado para tal finalidad. En el caso de las mujeres que acababan de dar a luz, se organizaban clases improvisadas en los pasillos del área de neonatología del hospital, con la finalidad de aprovechar la llamada "ventana de oportunidad" del puerperio inmediato dentro de la institución. En las primeras charlas, se invitaba a compañeres o parientes, mientras que las segundas, más breves, eran destinadas solamente a las madres. Diferentes agentes participaban de las charlas: médiques, obstetras, enfermeres, asistentes sociales y mujeres voluntarias del grupo de promoción de la lactancia materna que, adhirió a la Iniciativa Hospital Amigo de la Madre y el Niño (OMS) ${ }^{6}$ en el año 2006.

En el hospital, el espacio donde se realizaban las charlas de promoción de la lactancia materna para mujeres parturientas, se configuraba desde una lógica asimétrica y escolarizante. En una de las paredes se encontraba colocado un pizarrón. Al fondo del pasillo se disponían las sillas donde se sentarían las mujeres. En la distancia que iba desde el pizarrón a las sillas circulaba la promotora de lactancia, apuntando al pizarrón con un láser, con una mano en la cintura, mirando al pizarrón y al público alternadamente mientras presentaba los contenidos básicos del encuentro. Desde las primeras horas pos parto las mujeres son sometidas a dispositivos institucionales pedagógicos, descuidando cualquier instancia de mayor intimidad y cuidado con ellas.

6 La Iniciativa Hospital Amigo de la Madre y el Niño fue lanzada en 1991 en forma conjunta por dos organizaciones internacionales: La Organización Mundial de la Salud (OMS) y el Fondo de las Naciones Unidas para la Infancia (UNICEF, por sus siglas en inglés). Esta política se lanzó 'para animar y reconocer a los hospitales y maternidades que ofrecen un nivel óptimo de cuidado para la lactancia' y capacita al personal de salud, reconociendo a los hospitales que cumplen con los diez requisitos que el protocolo de esta política impulsa. La participación en la evaluación es voluntaria, nace del pedido del personal de la institución, y se efectiviza mediante la consecución de una reorganización total de la misma en lo referente a la promoción de la lactancia-materna, involucrando diversos aspectos de la práctica hospitalaria. 
Las mujeres-madres que se convocan desde los cuartos comienzan lentamente a llegar. Caminan despacio, parecen doloridas. En general están en camisón, con sus bebés nacidos hace menos de 24 horas en brazos. Algunas, que parecen no poder sentarse debido al dolor pélvico, deambulan. (Diario de Campo)

Desde la percepción de les profesionales, las mujeres que recién dieron a luz son sujetos pasivos, sometidos a procedimientos:

[Para dar las charlas]... las sientan a las mamás, las sacan de las habitaciones [...] y ahí les empiezan a hacer preguntas... [...] '¿porqué será que al bebé se le da la leche?' [...] Lo que sí nos pidieron que saquemos a las madres. Porque había una que no quería ir. Había algunas que no querían. Entonces le decían que era importante, ique te van a enseñar! Y ya salía la mamá. (E7, residente en enfermería. Énfasis nuestro)

La descripción de estos encuentros nos provee de una idea respecto a las posiciones relativas de mujeres-madres y "especialistas" en lactancia, donde son estes últimes les detentores de conocimiento para poner en práctica un saber supuestamente "natural”.

En un hueco de silencio, la enfermera dice:

- No tienen ninguna pregunta?

Una mujer pregunta por los gases del bebé, y ella comienza a responder:

- Solamente hay que dar el pecho de la mamá. No hay que darle ningún té. Ya va a empezar la abuela con los tecitos de todos los yuyos que se les pueda ocurrir. Vienen intoxicados muchos bebés al hospital. Consulten siempre al médico si quieren darles algo. (Diario de Campo)

El contexto etnográfico evidencia una forma de expropiación de la experiencia íntima de crianza, donde el modelo de maternidad deseable para el hospital se vincula con la consulta médica como lugar de legitimación de las prácticas maternas, operándose un corte en la relación de las madres con sus propias madres, parientes y grupos de pares. Se presenta el entorno de las mujeres como un espacio desautorizado, deslegitimando las prácticas de cuidado y cura populares. Ello propicia, de forma directa o indirecta, la debilitación de las redes femeninas y de cuidado. Se promueve así el quiebre de generaciones en manos de las prerrogativas de una "maternidad científica”, donde la madre se sitúa como única responsable de la criatura. 


\section{UNA RED DE APOYO JERÁRQUICA}

Las mujeres son responsabilizadas individualmente por el bienestar de les niñes, en un contexto hospitalario y en un espacio aislado de su cotidianidad, donde sus propias redes vinculares son deslegitimadas. Así, la institución se coloca como red de apoyo legítima: una red de apoyo particularmente jerárquica, asimétrica y que se descontextualiza del flujo de la vida de la mujer y su(s) hije(s). El ideal médico, que históricamente se opuso a las prácticas "culturales" de les pacientes, las fuerza a perder en este contexto su valor de verdad, inaugurando posiciones de poder estrictamente reguladas. Así, en el espacio hospitalario bajo estudio, la promoción de la lactancia materna se presenta como un proceso vertical donde pretenden implantarse determinados saberes en un cuerpo vacío - o, bien, lleno de una “cultura” equivocada, que precisa ser desaprendida - y se espera que germinen en prácticas de buena maternidad institucionalizada. Los grupos de apoyo a la lactancia materna representan, a estos fines, actores clave. ${ }^{7}$

A lo largo de las observaciones etnográficas en campo, fue posible registrar las múltiples formas de abuso, como la infantilización y la degradación moral, extorsiones, ridiculización pública, actos o discursos de menosprecio; así como violencias de tipo físico como forcejeos, tirones, desnudez no consentida en las reuniones grupales, en las salas de espera o dentro de los consultorios. Estas prácticas impactan en las apreciaciones de las mujeres, reforzando la legitimación del saber médico- institucional por sobre los propios.

7 En Salta existían, a la época en que fue realizada la investigación, nueve grupos de apoyo a la lactancia, cuatro de ellos en la ciudad de Salta, y cinco funcionando en instituciones hospitalarias o centros de salud del interior de la provincia. Los grupos de apoyo a la lactancia materna son organizaciones de la sociedad civil que se hallan ligadas a las instituciones sanitarias por lazos voluntarios. Generalmente están a cargo de ellas mujeres-madres enfermeras, agentes sanitarias o mujeres-madres con alguna cercanía con el personal de salud, inclusive amistosa. No dependen del gobierno, son autoconvocades, generalmente instades por algún/a profesional de las ciencias de la salud. Periódicamente pueden recibir algún tipo de ayuda económica por parte del gobierno a través de la Comisión Provincial de Lactancia Materna. En la ciudad de Salta, así como había grupos vinculados a instituciones de salud públicas, había otros funcionado en clínicas privadas o inclusive en los domicilios particulares de las promotoras en lactancia. Como estos espacios se hallan débilmente institucionalizados, sus actividades se fortalecen o decaen a merced de los altibajos personales y laborales de las activistas involucradas. 
Todo el mundo venía a decirme qué era lo que tenía que hacer, mi suegra me decía una cosa, mi mamá otra [...] y cuando fui al pediatra le dije: - mire la verdad no sé qué hacer porque he escuchado tantas posiciones y nada, le hacía preguntas y él me iba desmintiendo todo viste, las cosas que son culturales, que vienen de... [suspira]. (E2, mujer madre promotora de la lactancia)

Les médiques, cuyo saber substituiría al de las madres, abuelas y otras mujeres de los entornos más íntimos de las pacientes, buscan una cercanía afectiva a la vez que consideran a las pacientes como objetos de estudio: "Me siento identificado con el dolor y con las afecciones de la mujer, me parecen interesantes, dignas de ser estudiadas”. (E9, médico de planta)

La institución enuncia un parámetro desde el que se produce la comprensión de las desviaciones. La no realización de la lactancia-materna en las mujeres-madres es explicada por les profesionales de la salud como una forma de desviación, acontecida a partir de limitaciones materiales, conflictos familiares o carencias afectivas. En este ámbito, “ser capaz” de dar de mamar es parte de asumir el mejor rol femenino posible: el de la "buena maternidad", que las prácticas hospitalarias buscan producir de forma biopolítica. En la clave de una lectura afectiva diádica, no amamantar se coloca como una cuestión de "falta de autoestima" o "falta de información" de las mujeres-madres. Si el embarazo fue no deseado, la lactancia materna se configura, desde el punto de vista de enfermeras y médiques, como el mejor momento para alimentar el vínculo.

Hay mamás que... digamos que se minimizan en seguida en cuanto al amamantamiento porque creen que no pueden o no van a poder o no es tan fácil como pensaban, hay otras que no era un embarazo deseado entonces tampoco hay una búsqueda del vínculo. (E11, enfermera de planta)

El personal especializado exige un cuerpo íntegro y conectado con sensaciones y afectos en un contexto social de alienación de la corporalidad, donde los afectos primarios de la mujer madre son deslegitimados en cuanto transmisores del saber maternar. Se pide a las mujeres, en un momento extremo de precariedad de la vida, que sean agentes de su cuerpo haciéndolas sujetas de normas exteriores irrefutables. Se exigen controles de horarios, orientaciones médicas, mandatos y todo tipo de esfuerzos para alcanzar el "instinto" 
necesario para una buena lactancia. La institución, como una mano protectora e invisible, propicia la materialización del vínculo:

El instinto es el papel más importante, siempre y cuando no exista lo externo, que rompa ese instinto... ique lo rompe seguro! [...] Ahí vas rompiendo con todo lo que es la naturalidad, la naturaleza de la madre, el instinto, tratando de buscar otra cosa... el instinto de dar el pecho, el instinto de protección, el instinto de amor de madre... porque eso es así! (E12, médica de planta. Énfasis nuestro)

La enfermera, se presenta a sí misma y a la institución como agente de ese vínculo de amor. Las prácticas y discursos institucionales se desencarnan de la acción humana y aparecen como normas incuestionables, a-históricas, inherentemente válidas y, finalmente, “ideales y naturales”. En las prácticas observadas, el personal médico y de enfermería busca producir gestos de afecto que inauguren el vínculo. "Una vez que lo envuelven, que lo limpian recién te dicen mamá aquí está tu bebé, ese es tu bebe te dicen, dale un besito que se yo... [risas] con mi nena me paso así, 'dale un besito'!” (E3, mujer madre. Énfasis nuestro)

La adhesión a las reglas vigentes y a su reproducción representa una forma, aún cuando precaria, de poder como potencia positiva, remedio, inclusión, vida. Las mujeres se tornan una fábrica de individuos: del cuerpo liberal, individual, surge(n) otro(s) cuerpo(s) igualmente individual(es), y dependiente(s) casi exclusivamente de la madre, cuya subjetividad abierta es invisibilizada por la mirada médica.

\section{NORMAS INSTITUCIONALES COMO DISPOSITIVOS BIOPOLITICOS}

Las normas hospitalarias relativas a la lactancia materna se refuerzan y se basan en materiales escritos, que encontramos en el hospital por doquier. La norma hecha espacio será el primer paso para la norma hecha carne.

Una enfermera me invita a entrar a la zona de trabajo, donde hay colgada una carpeta. 'Es la política de promoción de la lactancia materna del hospital, está en todos lados'. Me invita a leerla. La carpeta está sujetada a un cable, que impide llevársela [...] Más adelante, una médica de la institución me regalará una copia. (Diario de campo) 
La adhesión a normativas de la OMS y UNICEF guía las prácticas de lactancia materna en el interior de la institución. En relación a la adhesión a Hospital Amigo de la Madre y el Niño, una médica comenta:

Todo el mundo piensa que hay un beneficio económico. Y esto es un título ho-no-rífico. Vos tenés el HONOR de integrar una red de muy pocos hospitales... pero son hospitales chicos... vos tenés una madre al mes! Trabajar con ella es fácil. Los hospitales de más de cinco mil partos son contaditos con los dedos de la mano. Es el honor de decir ya logré este objetivo de ayudar a la nación y tratar de que los niños se enfermen y mueran menos. (E12, médica de planta)

En este marco, las prácticas micropolíticas de control de la lactancia contribuyen a un bien mayor, que es una política institucional avalada internacionalmente. En este sentido, todo el personal del hospital es estimulado a "vestir la camiseta" de la iniciativa.

Yo quisiera que cuando vos bajes por acá y al vigilador por ejemplo, le preguntes [...] preguntes [...] ‘CCómo controla la lactancia materna?' [...] ' $y$ ves una persona de limpieza, y le preguntás, ellos te van a decir'. $Y$ vos decís '¿Sabe cuánto tiempo tengo que darle la leche a mi bebé?', ellos te van a decir. (E12, médica de planta. Énfasis nuestro)

Así, la institución cumple su función eugénica (STEPHAN, 1991) produciendo un modelo de maternaje desde el cual las mujeres se construirían. Este modelo produce jerarquías de saber-poder no sólo entre especialistas y madres, sino también entre madres. La "promotora de lactancia” se encontraría más cercana al "modelo".

Me llama ella [una enfermera] y me dice si yo estaba interesada en participar en el grupo de lactancia materna y me pregunta si yo le había dado lactancia exclusiva, le digo que SÍ, entonces era la candidata perfecta porque imaginate, terrible bebé [por su aspecto sano y robusto] encima con la historia de neonatología [nació prematura], todo eso... estaba ideal el modelo! (E4, mujer-madre voluntaria de grupo de apoyo. Énfasis nuestro)

La figura de las personas que voluntariamente participan de los grupos de apoyo nos interesa especialmente. ¿Qué lleva a alguien a adscribir gratuitamente en este tipo de actividades? ¿Qué procesos de don y contradón, 
alejados del contrato laboral-económico, juegan en estas actividades que también implican, ciertamente, trabajo? ¿Qué nociones sobre lo bueno y lo malo, lo deseable o lo indeseable, operan entre las personas que difunden esta práctica? El hecho de participar en algo voluntariamente no implica que no haya distribución de dones, de cuotas de poder, una movilización de intereses, en fin, una acumulación de otros tipos de capital que trascienden al financiero. (BOURDIEU, 2000) En este contexto, el voluntarismo, la beneficencia, la gratuidad, no son operaciones neutrales.

La totalidad de las mujeres-madres voluntarias de los grupos de apoyo entrevistadas pertenecía a las clases dominantes. Era común escuchar, entre ellas, que quienes no amamantaban lo hacen por falta de información, por influencias sociales o bien, en última instancia, por "falta de apoyo" de la red social más próxima a las mujeres lactantes.

[Aquí en Salta] Yo tampoco veo que hay buena información... [una mujer dice] 'ay no porque mi leche no era buena, ay no porque se me cortó la leche' yo digo por qué, si todas somos capaces de dar de mamar [...] son influenciadas por los pediatras o por la sociedad, viste? (E2, mujer-madre voluntaria de grupo de apoyo)

Las voluntarias suelen utilizar la propia experiencia como ejemplo y modelo de aproximación a la norma. Una de estas promotoras, cuya hija permaneció internada en neonatología, comenta acerca de otra mujer cuyo hijo estaba en la misma situación y con la que compartía el espacio de la espera, la extracción de la leche, las caminatas en los pasillos.

Y más ésta que... era mas lenta... te juro la tenían que obligar a que se bañe... porque tenía todos los olores que puede llegar a tener un ser humano... iy bien potenciados! Y no se podía estar al lado de ella... y yo no se como eso dejaban, permitían, me entendés, en neonatología... ella podía lavarse las manos, todo lo que quierás, para darle el pecho a su bebé, pero el olor a pata... iera impresionante! (E4, mujer madre voluntaria de grupos de apoyo. Énfasis nuestro)

En el vínculo promovido dentro de la institución, predomina la regla de priorizar al bebé, siendo exclusivamente la madre quien debe darse a esta tarea. Con ello opera el sometimiento, socialmente consentido, de la madre al deseo de otres adultes que, valiéndose de un supuesto deseo 
infantil, colocarán la leche de la mujer-madre biológica en el lugar de dádiva humana incondicional.

No podía dormir porque no quería dejarla solita. entonces trataba de estar lo más que podía pero lamentablemente vos tenés que descansar porque si no, no, no sirve, ino funcionás! [...] tenía que comer obligadamente para poder producir leche, pero después de ahí no... si era por mí, no tenía ganas ¿viste?. (E4, mujer madre voluntaria de grupo de apoyo. Énfasis nuestro)

La buena maternidad se deja conducir por la obediencia a las normas institucionales: la comensalidad compulsiva se realiza principalmente entre mujeres más precarizadas, que no podrían elegir cómo ejercer su maternaje ni la comensalidad de sus hijes.

\section{LACTANCIA MATERNA EN PERSPECTIVA INTERSECCIONAL}

La lactancia atraviesa el campo que constituye a los sectores populares como problema social. (DONZELOT, 1990) Siguiendo los imperativos biopolíticos de un discurso del riesgo, se promueve la lactancia materna en las geografías de la pobreza, definidas por aquellos espacios que sufren de mayor riesgo social (NOVICK, 1993): En este sentido, la alimentación por lactancia materna aparece como un factor de disminución de riesgos.

Nuestra función es intervenir en las problemáticas sociales con las que viene el paciente. El paciente, ser humano, no solamente viene con su enfermedad sino con un cúmulo de cuestiones familiares, sociales que muchas veces afloran, o reflotan, o explotan, acá. Entonces nosotros intervenimos, y de acuerdo a la problemática que se trate, y al grado de riesgo social, las actuaciones se harán de acuerdo a eso. Desde abuso sexual en menores, en adultas, violencia familiar, abandono de recién nacidos, casos de enfermedad inmunodeficiente [...] montón de situaciones donde el Estado debe apoyar al paciente carenciado. [...] hay una situación de riesgo para la contención de ese niño! [...] nosotros tenemos que ver qué tan riesgoso es el tema. (E10, entrevistada área social del hospital)

Dentro de la lógica de un sistema de salud pública configurado en torno a fuerzas de reproducción de la vida embutidas dentro de un sistema capitalista periférico, la adhesión a la lactancia materna obedece a principios liberales, clasistas y economicistas. Mujeres pobres, de forma individual y 
colectiva, son invitadas a generar menos gastos en el sistema público de salud, tornándose cuerpos para el Estado.

De última ien que impacta la lactancia materna a nivel de sociedad? en que vos vas a tener bebés más sanos mamás más sanas; si tienes bebés más sanos estas incluyendo ya la parte económica los costos de salud porque vas a tener menos dinero gastado en estos bebés que se alimentan en forma artificial, esos bebés, [cosa] que significa no solamente más mamaderitas y más tetinas, es más gasto médico porque son bebes que se enferman más seguido. (E11, Enfermera de planta. Énfasis nuestro)

Ya han sido estudiadas las maneras en que la violencia estructural de una sociedad sexista, clasista y racista es pasible de ser aplicada con mayor fuerza mientras mayor sea la situación de vulnerabilidad social en la que las mujeres se encuentran. Ya en el caso de mujeres-madres que poseen algún tipo de deficiencia, el capacitismo incide agudizando el peso de los poderes opresivos sobre cuerpos y subjetividades femeninas. Transcribimos aquí un relato en el que una voluntaria cuenta cómo intentó que una mujer-madre con rasgos de deficiencia mental amamantara a su hija.

Me tocó una chica, veinte años, demasiado lerda de entendimiento ya... ¿cómo me dijo la enfermera? Algo de 'riesgo no se qué', o sea, la chica era tontita. Tenía un grado de... ahora no me sale la palabra. [...] Yo llego, justo la bebé estaba llorando, entonces yo la alzo y le digo 'a ver mamá, ¿vos ya le diste la teta?'. Y ella no hablaba, y si hablaba, te hablaba muy poco. ¿Le diste la teta, la pusiste en el chichi?'s 'No', me responde. 'Sabés cómo se hace?'. 'No', repite. 'Bueno a ver, vení, yo te explico', le digo. La dejo a la bebé de nuevo en la cuna y agarro y le digo 'vos tenés que hacer eso' y yo agarro, y me saco el chichi [hace un gesto como de abrir su propia camisa]... ella tenía un camisoncito abotonado. 'Despréndete la camisa y sacáte', le digo. Entonces ella se abre la camisa y saca el chichi, como lo tenía puesto yo. Entonces yo me guardo todo, le digo 'ahora con el chichi así, vos lo que tenés que hacer es agarrar el bebé. Se lo paso al bebé y le explico: 'bueno acá acá, vos lo que tenés que hacer... mirá mirá cómo busca chichi el bebé'... iporque el bebé ese estaba como loco!... Y cuando logra prenderse al chichi, el bebé quiere chupar, y ella lo quita. Lo saca de golpe así, claro, el gordo se pone a llorar. Y te juro que en ese

8 Chichi significa teta, en quechua. Es una expresión de uso popular y contemporáneo del noroeste argentino. 
momento no sabía... trágame tierra, porque realmente no tenía ganas de estar ahí. Justo llega la enfermera, entonces me dice '[a ella] le tenés que decir las cosas por lo menos tres, cuatro veces para que te entienda...!'. Le digo 'mirá es normal que tome el chichi', le digo así, 'porque el bebé tiene hambre, vos cuando tenés hambre comés, él cuando tiene hambre necesita tomar la teta... a ver ponelo de nuevo', le digo así. Entonces ella con desconfianza, lo acerca, bueno, [el bebé] se prende del chichi. Entonces agarra, me dice 'me duele'. Cuando yo me fijo, claro, el bebé le había agarrado la puntita del pezón, entonces claro que le dolía... voy a lavarme las manos rápido y le meto el dedo al gordo para que largue... 'te tiene que agarrar todo esto mamá, viste bueno, y la tenía que tocar, porque no tenía otra forma de explicarle. 'Vos tenés que meter todo esto mamá... yo te aprieto así y te duele?' 'No', me dice. 'Bueno, así te tiene que apretar el bebé, me entendés?’ Entonces me mira, y asiente. Entonces lo pone al bebé, le mete en la boca y cuando agarró bien el bebé agarra y se pone a tomar, tomar tomar como loco. Entonces se quedó ahí, y le digo 'bueno, para que estés más cómoda, te pongo un almohadón'. Entonces se quedó ahí. Me voy a verla a la enfermera 'lo prendí al chichi... está tomando', le digo... 'ahora si no come, le vas a tenés que explicar vos, porque yo no estoy capacitada realmente para tratarla... a veces realmente me saca de quicio... [...] entonces ya me fui, porque me sentí que no daba para más. (E4, mujer madre voluntaria del grupo de apoyo)

Aquí, la madre voluntaria se encuentra en una posición más cercana al ideal que su par "deficiente" y ella se coloca como como autoridad en el tema a la vez que reconoce la propia falta de preparación para lidiar con la diferencia - una condición materna divergente de la maternidad normativa. Desde una perspectiva de interseccionalidad entre género y capacitismo, notamos que

[...] el fenómeno de la deficiencia [...] no se encierra en el cuerpo, y sí en la producción social y cultural que define determinadas variaciones corporales como inferiores, incompletas o pasibles de reparación/rehabilitación cuando se encuentran situadas en relación con la corponormatividad, esto es, con los patrones hegemónicos funcionales/corporales. (Mello, 2014, p. 25)

Los obstáculos que atraviesa una persona con deficiencia se multiplican si ella es mujer, se acentúan si es madre y se intensifican aún más si ella es usuaria del sistema de salud público. 


\title{
CONSIDERACIONES FINALES: POR EL DERECHO DE LAS MUJERES-MADRES A DECIDIR
}

\begin{abstract}
No siempre la posibilidad de dar está acorde con una posición superior en la jerarquía social. Cuando la posibilidad de dar se transforma en una obligación, y esta obligación no tiene un contradon visible: ¿hay violencia incrustada en el don?. (YAN, 2005, p. 1, traducción nuestra)
\end{abstract}

El epígrafe de Yunxiang Yang (2005) nos invita a pensar en las prácticas de comensalidad en su relación con modelos que incluyan una reflexión sobre la desigualdad a la que los intercambios de alimentos entre seres sociales están sujetos. ¿Cuál es el lugar de la integridad y la dignidad humana cuando el derecho a amamantar de una mujer-madre deviene en obligación? Como sostiene Cristina Martín (2019), los avances feministas han construido un fuerte consenso en torno a la libertad de las mujeres para decidir sobre sus propios cuerpos en el ámbito de las prácticas sexuales, los cuidados anticonceptivos y aún el aborto, pero esta voluntad política no se ha extendido al ámbito de la lactancia materna, que aparece como una isla de acuerdos burgueses donde imperan ideas normativas de la buena maternidad.

Destacamos aquí que, desde una perspectiva jurídico-política más universalizante, la lactancia puede comprenderse como un derecho de las mujeres y de les niñes, con beneficios afectivos y relacionados con la salud que impactan en ambes. Sin embargo, al aplicar nociones de equidad al discurso universalista de los derechos de ambes, observamos que es necesario repensar las prácticas encarnadas relativas a conceptos como díada, red de apoyo y naturalidad del acto lactante.

Cuestionar el lugar central de la díada madre-hije en las prácticas de maternaje involucra considerar que la expansión de los derechos de las mujeres-madres no implica, necesariamente, un retroceso de los derechos de les niñes. Formas no nucleares, no reproductivistas, no familistas de cuidado deben ser percibidas y, como verdaderas estructuras de red, estimuladas para realizar su mejor performance. La problematización sobre la socialización, la democratización y la descolonización de los cuidados indica que es preciso incorporar en los diagnósticos y estudios sectoriales 
el análisis de las disparidades entre hombres y mujeres, por un lado, y entre las propias mujeres, por el otro, tanto en el transcurso de su trayectoria laboral (BIDEGAIN; CALDERÓN, 2018), como de su trayectoria familiar, social y reproductiva.

El derecho a la lactancia ha sido conquistado como tal a partir de las reivindicaciones de los movimientos sanitaristas a nivel mundial. Ahora bien, lo que se colocó como deseable por especialistas - hombres y mujeres - de los sistemas públicos de salud no es necesariamente lo que las mujeres han deseado y han podido, desde la diversidad de sus experiencias encarnadas, históricas y particulares. Como hemos podido ver a lo largo del texto, en la decisión de amamantar entran en juego diversos factores: condición de clase, cuerpo-normatividad, las redes de apoyo, entre tantos otros condicionantes que definen el margen de maniobra posible alrededor de la elección de amamantar e, inclusive, de no hacerlo.

En este sentido, deberían garantizarse un mayor número alternativas de alimentación y comensalidad posibles, explorando lazos de leche, bancos de leche horizontales y solidarios, así como otras formas de comensalidad infantil que no requieran de la leche humana - substancia femenina. Por otra parte, sugerimos acciones que fortalezcan la autonomía de las mujeres, sus deseos y sus elecciones basadas en las posibilidades reales de las mismas dentro y fuera del contexto hospitalario, contemplando lógicas de cuidados más amplias que la lactancia y que prioricen, de forma irreductible, el protagonismo femenino en todos los momentos del ciclo reproductivo.

En este texto, hemos dirigido la fuerza de nuestra mirada etnográfica hacia las opresiones institucionales y biopolíticas, dejando las resistencias, que sabemos existentes y muchas veces silenciosas, en los bordes de lo que ha sido posible presentar aquí. Deseando que se haga carne la contribución de nuestra reflexión para formas más democráticas de comensalidad y cuidado, destacamos finalmente que poder debatir, ponderar y finalmente elegir nuestros maternajes y formas de comensalidad lactante debe ser un derecho extendido a todas las madres, fortaleciendo espacios de diálogo horizontal como redes de apoyo femeninas que, trascendiendo la díada disciplinadora madre-hije, extienda la fuerza viva de los cuidados como una red activada, desde abajo y hacia los lados, a partir todos los puntos del tejido social. 


\section{REFERÊNCIAS}

ALCOFF, L. M. Merleau-Ponty y la teoría feminista sobre la experiencia. Revista Mora, Buenos Aires, n. 5, p. 122-138, 1999.

ANZALDÚA, G. Borderlands/La Frontera: the new mestiza. San Francisco: Aunt Lute Books, 1987.

BADINTER, E. ¿Existe el amor maternal?. Barcelona: Paidós, 1981.

BIDEGAIN, N.; CALDERÓN, C. Los cuidados en América Latina y el Caribe: documento digital. Santiago: Naciones Unidas, 2018.

BOURDIEU, P. La dominación masculina. 2. ed. Barcelona: Anagrama, 2000.

BUTLER. J. Corpos que pesam: sobre os limites discursivos do sexo. In: LOURO, G. L. (org.). O corpo educado: pedagogias da sexualidade. Belo Horizonte: Autêntica, 1999. p. 151-172.

CRENSHAW, K. Demarginalizing the Intersection of Race and Sex. Chicago: University of Chicago Legal Forum, 1989. p. 139-167.

CSORDAS, T. Modos somáticos de atención. In: CITRO, S. (coord.). Cuerpos plurales: antropología de y desde los cuerpos. Buenos Aires: Biblos, 2011. p. 83-104.

DONZELOT, J. La policía de las familias. Madrid: Pretextos, 1990.

ECHAZÚ-BÖSCHEMEIER, A. G. E. Lactancia-materna y políticas de salud: un estudio de caso en el Nuevo Hospital El Milagro. 2007. Tesis (Licenciatura en Antropología) -Universidad Nacional de Salta, Salta, 2007.

ECHAZÚ-BÖSCHEMEIER, A. G. Lactancia-Materna y 'Polítcas de Salud: un estudio de caso en el nuevo hospital el milagro. In: ÀlVAREZ-LEGUIZAMÓN, S. (org.). Poder y salteñidad: saberes, política y representaciones sociales. Salta: CEPIHA, 2014. p. 183-196.

ECHAZÚ-BÖSCHEMEIER, A. G. E.; MARTON, B. La violencia simbólica de las representaciones en salud: el caso da díada madre-hijo y la lactancia materna. Sexualidad, Salud y Sociedad, Rio de Janeiro, v. 5, p. 119-143, 2010.

ECHAZÚ-BÖSCHEMEIER, A. G. Elos de leite, elos de sangue: notas etnográficas na comunidade quilombola de Boa Vista dos Negros 2008-2010. Natal: EdUFRN, 2014.

FLEISCHER, S.; FERREIRA, J. Etnografias em serviços de saúde. Rio de Janeiro: Garamond, 2014.

FOUCAULT, M. Nascimento da biopolítica (1978-1979). São Paulo: Martins Fontes, 2008.

GOMES, E. C.; MENEZES, R. A. Etnografias possíveis: "estar" ou "ser" de dentro. Ponto Urbe, São Paulo, n. 3, 2008. Disponível em: https://journals.openedition.org/ pontourbe/1748. Acesso em: 20 jun. 2020. 
GRECO, L. R.; OJEDA, P. D. Arte gestante-maternidades insurrectas: una narrativa del cuerpo gestante desde el Butoh y los cuidados. Revista Sociopoetica, Campina Grande, v. 1, n. 21, p. 87-199, 2019.

GROSZ, E. Volatile bodies. Sydney: NSW, 1994.

HÉRITIER, F. Reflexiones para alimentar la reflexión. In: HÉRITIER, F. Séminaire de la Violence. Paris: Odile Jacob, 1996. p. 13-53.

LANGDON, E.; WIIK, F. Antropologia, saúde e doença: uma introdução ao conceito de cultura aplicado às ciências da saúde. Revista Latino-Americana de Enfermagem, Ribeirão Preto, v. 18, n. 3, p. 174-181, 2010.

LEGUIZAMÓN, S. A. Poder y salteñidad: saberes, políticas y representaciones sociales. Salta: CEPIHA, 2010.

MACHADO, L. Z. Deslocamentos de práticas e saberes feministas; interrogações brasileiras sobre estudos norteamericanos. FAZENDO GÊNERO 9: DIÁSPORAS, DIVERSIDADES, DESLOCAMENTOS, 9., 2010, Santa Catarina. Anais [...]. Santa Catarina: Fazendo Gênero 9, 2010. p. 1-10.

MARTÍN, C. La guerra de la lactancia: ideas para un debate en el feminismo. El Salto, [s. l.], 25 set. 2019. Disponível em: https://www.elsaltodiario.com/opinion/ guerra-lactancia-ideas-debate-feminismo. Acesso em: 27 jul. 2020.

MBEMBE, A. Nécropolitique. Raisons politiques, Paris, v. 1, n. 21, p. 29-60, 2006.

MELLO, A. G. Gênero, deficiência, cuidado e capacitismo: uma análise antropológica de experiências, narrativas e observações sobre violências contra mulheres com deficiência. 2014. Dissertação (Mestrado em Antropología Social) - Programa de Pós Graduação em Antropologia Social, Universidade Federal de Santa Catarina, Florianópolis, 2014.

MUÑOZ, K. O. Miradas en torno al problema colonial: pensamiento anticolonial y feminismos decoloniales en los Sures globales. Madrid: Akal, 2019.

NOVICK, S. Mujer, estado y políticas sociales. Buenos Aires: Centro Editor de América Latina, 1993.

OLIVEIRA, L. R. C. Pesquisa em versus pesquisas com seres humanos. In: VICTORA, C.; OLIVEN, R. G.; MACIEL, M. E. et al. (org.). Antropologia e ética: o debate atual no Brasil. Niterói: ABA, 2004. p. 33-44.

OTERO, F. Higiene del niño. Paris: Cabaut y Cía Editores, 1922.

QUINTERO, P. Yo, tú, elle, nosotres, vosotres, eles: el lenguaje inclusivo: ¿tiene algo que ofrecer?. Psyciencia, [s. l.], 2019. Disponível em: https://www.psyciencia.com/ lenguaje-inclusivo-investigaciones/. Acesso em: 17 jan. 2020.

RIBEIRO, D. O que é lugar de fala?. Belo Horizonte: Letramento, 2017. 
RICH, A. Of Mother Born: motherhood as experience and institution. London: Virago, 1986.

STEPHAN, N. L. The Hour of Eugenics. New York: Cornell University Press, 1991.

VAN ESTERIK, P. Breastfeeding: a feminst issue. [S. l.: s. n.], 2002. Disponível em: http://www.promom.org. Acesso em: 27 jan. 2020.

YAN, Y. The gift and gift economy. In: CARRIER, J. (org.). A Handbook of Economic Anthropology. Massachussets: Edward Elgar Publishing, 2005. p. 246-262. 


\section{Darte II \\ CÓdIGOS IDENTITÁRIOS E ALIMENTAÇÃO}





\title{
IDENTIDADES DESLOCADAS EM TERRITÓRIOS ESTRANGEIROS A COMENSALIDADE NO FILME PERSÉPOLIS ${ }^{1}$
}

\author{
SILVANA SILVEIRA CAMPOS \\ FRANCISCO ROMÃO FERREIRA \\ CRISTIANE MARQUES SEIXAS \\ ELIANE PORTES VARGAS
}

\section{INTRODUÇÃO}

Eu não sou uma política. Eu não sei como resolver os problemas do mundo. Mas como artista, eu tenho uma obrigação: fazer perguntas

Marjane Satrapi

Uma das palavras necessárias para olhar a comensalidade na atualidade é o deslocamento. Trata-se de tomar o deslocamento das pessoas no mundo como objeto do olhar, mas também de deslocar o próprio olhar, sair do espaço onde se tem apenas uma perspectiva e ampliá-lo. Para tanto,

1 Este texto deriva da tese de doutorado de Silvana Silveira Campos em andamento no Programa de Pós-Graduação em Alimentação, Nutrição e Saúde da Universidade do Estado do Rio de Janeiro e recebe financiamento da Fundação de Amparo à Pesquisa do Estado do Rio de Janeiro (FAPERJ). 
elegemos o filme frânces Persépolis ${ }^{2}$ como objeto de estudo, no qual se busca destacar determinadas cenas e, por meio delas, apresentar características de alguns personagens em momentos de comensalidade. O cinema é o lugar de observação da memória afetiva do sujeito que traduz uma memória afetiva individual que é, ao mesmo tempo, familiar e remete aos amigos e ao país de origem. A partir das cenas escolhidas refletiremos sobre as relações sociais e a construção de uma identidade no imigrante contemporâneo e sobre vínculos construídos e resgatados a partir da relação com a comida. Nesse sentido, objetivamos colocar em discussão o papel da comensalidade como um espaço simbólico de afirmação de identidade cultural e subjetividade do sujeito que migra para um território estrangeiro ou que se sente estrangeiro em seu próprio território.

Ao tratarmos da comensalidade nesse filme, foi possível perceber diferentes modos como ela se expressa na narrativa de um imigrante. Seja nas cenas à mesa em casa com a família, nas lembranças afetivas e gustativas da infância, nas lembranças com amigos na vida social, de modo solitário em um país estrangeiro ou entrando em contato com outras pessoas em território estrangeiro, sendo acolhida ou tratada corpo estranho àquele grupo, a comida e a mesa aparecem sempre como elemento de ligação que intermedeia as relações sociais, familiares, amorosas ou políticas. A comensalidade é reconhecida como elemento que dá um território simbólico para o sujeito que migra, na medida em que não é uma comensalidade objetiva, pelo contrário, ela é sempre imaterial e subjetiva, pois ajuda a construir uma identidade que vai substituir aquela territorial que foi perdida. Assim como outros símbolos utilizados na construção de uma identidade nacional que valoriza sua cultura e afirma uma subjetividade individual, a comida entra como elemento simbólico e como elemento estratégico de aproximação entre o sujeito que chega numa outra cultura, mas que deseja manter vínculos com o passado.

A escolha por uma produção cinematográfica como objeto de observação, parte de uma perspectiva teórica que entende o filme também como um dispositivo de linguagem capaz de narrar histórias, vivências e memórias de uma sociedade. (AUMONT, 1993) Através da representação do espaço e do tempo na imagem, a memória vai sendo revisitada. $\mathrm{O}$ filme que analisaremos

2 A ficha técnica completa nas referências ao final do texto. 
é uma animação, cuja narrativa é exercida por imagens gráficas ou desenhos em sua maior parte em preto e branco. O que se tenta representar é uma construção imaginária, ou seja, não é uma realidade dada, mas uma criação que é feita sobre ela.

A linguagem cinematográfica reproduz, cria, amplifica e dissemina ideias, conflitos e sensações humanas que são universais, tais como a fragilidade do sujeito diante de um ambiente político hostil, a impossibilidade de viver com liberdade de ideias, o afastamento compulsório da família e dos vínculos afetivos que constituem a identidade e a chegada em um lugar desconhecido, com outros códigos, valores e sabores. Tendo a mesa e a comensalidade como um lugar que retrata a universalidade dessas sensações, o cinema figura como uma possibilidade de memória, como uma linguagem com amplo repertório de códigos que permitem discursar sobre esses fenômenos, sendo, portanto, um interessante lugar de observação.

Além disso, podemos considerar que existe em todas as formas de vida humana uma necessidade de contar o que acontece. Contar histórias é uma forma elementar de comunicação humana. Ademais, através das narrativas, as pessoas lembram o que aconteceu e jogam com a cadeia de acontecimentos que constroem a vida individual e social. (BAUER; GASKELL, 2011)

\section{VISITANDO PERSÉPOLIS}

O filme Persépolis foi construído a partir de uma história em quadrinhos baseada na autobiografia de Marjane Satrapi. ${ }^{3}$ O filme é uma produção francesa de 2007, ${ }^{4}$ dirigido e roteirizado por Marjane Satrapi e Vincent Paronnaud e tem a personagem Marjane como narradora central da história. Através de ilustrações gráficas, Marjane narra de forma não linear acontecimentos de sua vida no Irã ${ }^{5}$ e na Europa: a derrubada do regime político do

3 Marjane Satrapi é o nome artístico de Marjane Ebihamis, nascida no Irã em 1969 e radicada na França, Marjane é uma ilustradora, romancista gráfica e roteirista de audiovisual.

4 Festivais e prêmios dado a Pérsépolis: indicado ao Oscar em 2008 na categoria de melhor animação; indicado ao Globo de Ouro 2008, como melhor filme estrangeiro; vencedor do EDA Female Focus Award, em 2007; Vencedor Silver Condor (Argentina) e Melhor Filme Estrangeiro, em 2009.

5 Nesse período o Irã foi palco de guerra e revoluções, década de 1980, interna e externa. A interna entre clérigos e os grupos que combinavam o Islã e o marxismo atingiu com fúria o controle da República Islâmica e posteriormente uma guerra também contra o Iraque. (MACKEY, 2008) 
Xá Mohammad Reza Pahlevi; a tomada de poder pelo governo Islâmico de Aiatolá Khomeini; o início da Guerra do Irã contra o Iraque; sua imigração sem seus pais para Viena; sua volta para o Irã após o exílio e novamente sua imigração para Paris.

Nessas idas e vindas de Marjane, questões identitárias, afetivas, políticas vão sendo colocadas na medida que a personagem se desloca nos diversos cenários do filme, mostrando igualmente a passagem do tempo e as fases da vida, conquistas e perdas num contexto sempre em mutação. Mudanças geográficas, existenciais e políticas acontecem. Movimentos entre o tempo da menina Marjane até a vida adulta, mudanças também numa sociedade iraniana que vai se tornando cada vez mais fundamentalista.

Na leitura de um filme, como num texto literário, as variadas formas de ler e de captar pontos do filme desvelam também a riqueza da obra. O filme traz em seu título uma reflexão sobre a procura do lugar ou de uma identidade que ficou pra traz. O nome Persépolis ${ }^{6}$ faz referência a uma cidade do passado que já não existe mais no mundo contemporâneo. Para cultura persa, Persépolis é a polis do período anterior a influência árabe e bizantina, período de grande força da sociedade persa e que em algum momento foi transformado em ruínas. Esse lugar que já não existe, fala também do sujeito que ali vivia e que não tem mais um território para chamar de seu.

A mudança para outra sociedade e outra cultura coloca em xeque o modo de ser, o modo de ver o mundo, o modo de se ver e o modo de se relacionar, trazendo à tona a questão de quem ela é. Esse desconcerto ocorre, pois, as pessoas são socializadas em uma determinada cultura e isto significa uma incorporação marcante de formas de sentir, de pensar e de agir. (DUBAR, 2002) O filme fala dos deslocamentos espaciais da personagem, dos deslocamentos no tempo e também dos deslocamentos nas relações sociais, nos circuitos de poder e de cerceamento da liberdade. A menina iraniana se desloca do oriente para o ocidente, sai de uma sociedade democrática que está se transformando em uma teocracia conservadora para viver na Europa. A tão sonhada liberdade europeia contrasta com o território repressor do Estado iraniano.

6 Persépolis é uma cidade em ruínas da antiga capital do Império Persa, fundada no século V a.C., antes dos conflitos Bizantinos. (MACKEY, 2008) 
Para Bauman, os deslocamentos e migrações de pessoas não são fenômenos recentes. Eles fazem parte da era moderna desde seus primórdios uma vez que

[...] nosso 'modo de vida moderno' inclui a produção de 'pessoas redundantes' (localmente 'inúteis', excessivas ou não empregáveis, em razão do progresso econômico; ou localmente intoleráveis, rejeitadas por agitações, conflitos e dissensões causadas por transformações sócio/políticas e subsequentes lutas por poder). (BAUMAN, 2017, p. 9, grifos do autor)

O autor acrescenta que o que tem acontecido nos últimos anos, é também um enorme salto no contingente de pessoas em busca de asilo, este salto foi causado também pelo número crescente de Estados "afundados”, ou já submersos, ou de territórios sem Estados, portanto, também sem leis, palcos de intermináveis guerras. Por outro lado, um dos principais teóricos dos estudos de migração, Abdelmalek Sayad (1998) critica abordagens que generalizam o olhar sobre um fenômeno que considera bastante complexo. Para o autor, a imigração, pode ser lida por diferentes perspectivas teóricas, já que o próprio trajeto do imigrante não é apenas espacial é também epistemológico.

Sejam as migrações e deslocamentos humanos recentes ou não, fato é que a contemporaneidade expõe de modo ostensivo, dia a dia, pessoas cruzando fronteiras na procura um lugar de existência e resistência. As mídias, assim como as redes sociais, são testemunhas desses fenômenos que sempre fizeram parte do continente europeu na sua relação com o continente africano, com o Oriente Médio ou com as Américas, mas atualmente observamos uma intensificação dos fluxos, o agravamento das tensões, o enrijecimento dos mecanismos de proteção contra os imigrantes e indicam a pertinência de interrogar esse fenômeno. Os casos expostos nas mídias diariamente de barcos de imigrantes no Mediterrâneo, assim como das tragédias decorrentes das incontáveis tentativas de mudar de lugar no mundo, mobilizam a opinião popular e constituem os exemplos contemporâneos dessa diáspora.

A desterritorialização física e cultural é uma das consequências do capitalismo global, movendo pessoas de um lugar ao outro em busca de um território para chamar de seu. Segundo Hall (2002), nas sociedades 
pós-modernas a identidade está profundamente ligada a questões que se relacionam com a mobilidade e a instabilidade espacial. A identidade não é mais definida biologicamente, mas sim historicamente. Como uma "celebração móvel”, a identidade é formada e transformada continuamente na medida em que somos representados ou interpelados permanentemente pela cultura.

É nesse sentido que destacamos a personagem do filme, pois ela assume identidades diferentes em diferentes momentos, identidades que não são unificadas ao redor de um Eu coerente e imutável. A comensalidade do migrante representada no filme remete a um espaço simbólico dando lugar ao estranho, que ao mesmo tempo fica sem visibilidade e está deslocada do familiar, no território estrangeiro. A comida parece dar um lugar estável num mundo instável. Por outro lado, este mundo instável gera sujeitos deslocados que sozinhos refletem o mundo individualista. A característica desvinculada das sociedades pós-modernas reflete mesas solitárias, sem vínculos, sem identidades definidas.

Aquilo que os homens têm em comum, considerando desde a mesa familiar até o banquete antigo que reúne uma cidade, são os costumes, as normas, os sinais identitários por meio de comportamentos à mesa. Se a relação em torno da mesa cria laços, com maior frequência ainda ela fortalece laços já existente. (BOUTAUD, 2011, p. 1215)

Para Stuart Hall (2002), dentro de nós há identidades contraditórias, empurrando em diferentes direções, de tal modo que nossas identificações estão sendo continuamente deslocadas. Para o autor, a ideia de uma identidade plenamente unificada, completa, segura e coerente é uma fantasia, pois o próprio processo de identificação, através do qual nós nos projetamos em nossas identidades culturais, tornou-se mais provisório, variável e problemático. As transformações políticas, religiosas e dos valores morais ocorridas no Irã mostram muito claramente como os contextos políticos mudam as relações pessoais e os lugares identitários tradicionais, transformando tudo em incerteza. Mas em meio a esse turbilhão de emoções e sentidos em fuga, as memórias gustativas e afetivas aparecem como um porto seguro, ancorando os sujeitos em suas memórias com relativa estabilidade diante de tanta instabilidade. 


\section{COMENSALIDADE ALÉM-FRONTEIRAS: O BANQUETE SOLITÁRIO}

Na sequência inicial de imagens do filme, destacamos o movimento de uma flor. ${ }^{7}$ A flor que se desloca no mapa geográfico e cênico é um jasmim. Ela desprende-se, voa, atravessa águas, atravessa oceanos que separa dois continentes. Jasmim ou em persa Yasmim, é também um nome comum na antiga Pérsia (atual Irã) e figura como um símbolo narrativo que traça rotas pelos ares, voando de um ponto a outro, tentando se fixar além-mar. Está solta no espaço geográfico, como os migrantes das sociedades contemporâneas do mundo. Sujeitos que tentam atravessar muros, oceanos e fronteiras transnacionais.

Marjane relembra cenas do passado, nos idos de 1978, época em que denomina como uma "vida tranquila" e "sem problemas". Uma vida de menina, em que adorava batatas fritas com ketchup, tinha Bruce Lee como ídolo e usava tênis Adidas, ou seja, símbolos de mercadorias transnacionais das sociedades de consumo. Nas lembranças de Marjane se vê imagens de festas, música, bebida e comida. Marjane, criança, corre livremente pelo ambiente familiar.

A confrontação entre imagens do filme que representam o espaço da comida ou o próprio comer, tanto em território estrangeiro quanto em Teerã, nos mostram uma subjetividade relacionada à comensalidade colocando em cena a memória do imigrante. No filme cenas de festas clandestinas no Irã, evocam uma possibilidade de evasão pela comida num sistema autoritário, migrar e sair para respirar ou beber e comer para respirar na opressão. Ir à festa não era seguro também, no entanto, era um dos poucos momentos de liberdade que lhes restava. ${ }^{8}$ É assim, como uma tentativa de fuga em busca de liberdade para viver, comer, beber e respirar que o filme percorre alguns lugares importantes que marcam com suas imagens símbolos que nos remetem a vários sentidos ocultos. Viajar é um elemento presente em toda a narrativa e o cenário dos aeroportos com suas diferença e semelhanças se alternam em vários momentos do filme e possibilitam um eixo de leitura da comensalidade.

7 Cena em 00:00:36.

8 Cena em 00:26:12. 
Aéreo vem do grego e significa: "do ar", que está nas regiões superiores: que atravessa o ar; vasto; infinito, brumoso, nebulos. (MACHADO, 1956) Porto, do latim, refere-se a regiões onde as embarcações podem estabelecer contato com a terra e de onde pode entrar e sair. (HOLANDA, 2010) Em Persépolis, ${ }^{9}$ há muitas imagens-porto: imagem de um aeroporto, um avião, o Aeroporto de Orly, pessoas circulando pelo aeroporto, escadas rolantes, um painel com horários de chegada e partida de voos para diferentes partes do mundo, uma mulher vestida com casaco vermelho, mala, tênis, burca, cigarro, elementos que capturam e dão sentido a um ambiente de circulação e de movimentação. Chegada de quem de algum lugar partiu, partida de quem em algum lugar chegará. Imagens de pessoas em trânsito, emoções confusas e identidades fragmentadas na perspectiva da linguagem cinematográfica.

Se o contexto do aeroporto e sua peculiar movimentação nos remetem aos sentimentos e sofrimentos relacionados às chegadas e partidas, podemos imaginar os dramas dos imigrantes que tentam entrar na Europa ou na América de modos não convencionais e os conflitos que desumanizam as pessoas e as transformam em párias, em não sujeitos, assujeitados e apequenados em sua humanidade. Nesse contexto de subjetivação, a comida e as diferentes formas de comensalidade garantem um vínculo com o que ficou distante, com a terra natal, com a cultura de origem, sustentando uma dignidade que impede a total desumanização. Se apegar aos sabores da terra natal se transforma então em um ato revolucionário, não significa apenas a saudade de um sabor, mas a memória de uma vida inteira que não se apaga.

Nas cenas de comensalidade nas quais a comida ou a mesa estão presentes, ainda que implicitamente, aspectos subjetivos ligados à identidade da personagem são suportes na construção desta reflexão, pois na bagagem Marjane leva, além dos elementos materiais, uma memória afetiva, gustativa e familiar que marca sua trajetória assim como a de qualquer imigrante. Sozinha, deslocada da cultura ocidental, a personagem tenta estabelecer vínculos no ambiente ocidental e se depara com grandes dificuldades. O mundo de liberdade esperado, é também, opressor e não possibilita a reconstrução dos antigos laços afetivos. O deslocamento geográfico da personagem vai causando diversos estranhamentos que, gradativamente, desestabilizam seus afetos e desorganizam sua forma de perceber o mundo.

9 Cena em 00:01:41. 
Esse estranhamento a impulsiona para uma busca de elementos com os quais se reconheça e se sinta segura no novo território.

Chegar num território estrangeiro é também aprender a ultrapassar as barreiras que separam os que vivem dentro daqueles que estão fora. Os muros, as cercas, as faixas de segurança, as leis de fronteiras, os guichês alfandegários, o idioma falado, o visto no passaporte, diversos são os elementos que servem para rejeitar ou impedir a mobilidade de imigrantes e tornam o trânsito pelos espaços além-fronteiras nacionais no mundo global. Há também barreiras que não estão claramente definidas. $\mathrm{O}$ estranho no ninho, portanto, anda em solo delicado. Sem saber o porquê, às vezes, ultrapassa regras que não tem o mesmo peso para quem já é local. Cabe aquele que chega decifrar códigos e regras do espaço estrangeiro. Há também que se entender que essas barreiras nem sempre são iguais para todos. As separações ocorrem carregadas de aspectos simbólicos e econômicos. Preconceitos e subjulgamentos.

A condição do estrangeiro, no novo território de moradia, é também o que permite identificar o outro baseado nos próprios estereótipos preconceitos. Ou seja, quem chega, assim como quem recebe o imigrante, também carrega suas referências a partir das quais julga o outro que não corresponde a um conhecimento sobre o outro. Se o imigrante é o conhecido/estranho, aquele que mora no território também o é de alguma forma. Por exemplo, no filme, uma das primeiras moradias de Marjane no território estrangeiro, ${ }^{10}$ foi em Viena, num pensionato comandado por freiras católicas. No pensionato, além de cozinhar a própria comida (espaguete), ir ao mercado local, onde se empolga com a possibilidade de achar produtos que não existiam em seu país, ela come uma macarronada, ao mesmo que tempo que assiste $\mathrm{TV}$, diferentemente do que fazia no Irã. Uma das freiras, contudo, repreende a menina alegando que ali não se come da forma como a menina estaria comendo. Marjane, incrédula, com a panela de comida na mão e com a boca cheia de comida, responde que não entende a repreensão da freira já que ali na pensão católica todos também comem assistindo TV. ${ }^{11}$ A freira irritada responde que ninguém ali come numa frigideira e que então seria verdade o que dizem sobre os iranianos não terem nenhuma educação.

10 Cena em 00:37:12.

11 Cena em 00:00:40. 
Marjane furiosa questiona gritando se seria também verdade que todas as freiras seriam ex-prostitutas. Este ocorrido, foi o limite então pra que ela fosse expulsa do pensionato, ocasionando também um período em que ela perambulasse por várias moradias, até encontrar outro lugar para morar. ${ }^{12}$

Segundo Prado e Wollz (1997 apud ARIÉS, 2017), o espaço da mesa com suas regras e rituais expõe dois eixos fundamentais para compreensão das relações sociais. Enquanto no eixo horizontal se encontra a sociedade com seus códigos e regras compartilhados, o eixo vertical expõe as hierarquias reforçando as relações sociais, os lugares e papeis definidos do jogo social. Essa mesa cenográfica onde Marjane come no convento possui de imediato uma dimensão teatral, que torna evidente as relações sociais em jogo. Ao mesmo tempo que ela tenta se adequar ao modus operandi daquele espaço social, fazendo a própria comida e comendo vendo TV, ela não se enquadra totalmente, pois usa a panela como prato, permitindo emergir na fala e na expulsão o preconceito velado contra os iranianos.

Os papeis representados ali traduzem os mesmos aspectos do cotidiano daquele grupo social cujas regras e convenções nem sempre são percebidas por aquele que chega em território estrangeiro. Os comensais estão ali para participar do jogo social. E nesse jogo convém que ele saiba o seu lugar social e a dinâmica do jogo, já que a comensalidade é o lugar que vai reforçar essa dinâmica. Caso contrário, se o comensal de alguma forma não respeita essa dinâmica, expõe seu caráter estranho.

Neste sentido, o estrangeiro é aquele que não sabe das regras e numa tentativa de ser aceito tenta copiá-las desconhecendo, contudo, que algumas regras intrínsecas não são expostas e esclarecidas logo de início. Algumas regras nunca serão totalmente acessadas, pois são constitutivas do habitus que se reitera e se dissemina no interior do grupo social. O estrangeiro é o bárbaro, ou seja, aquele que não sabe das regras e que no limite se apresenta ao outro como cruel. Marjane estava ali para participar do jogo, ou pelo menos tentar, contudo, errou as regras e, apesar de tentar se aproximar da cultura local, os estereótipos sobre ela prevalecem desvelando seu aspecto bárbaro para as freiras. Os desafios enfrentados por Marjane não foram apenas econômicos, como grande parte daquele que migra para um outro país. A personagem se defronta também com a necessidade de se 
definir quem é perante o novo cenário que se apresenta. Uma inquietação que reverbera ao longo do tempo e que se expressa numa percepção da possibilidade também de não ser mais a iraniana de antes e nem nunca poder ser uma europeia.

Sobre a questão de identidade, no caso da personagem ser iraniana ou não, Hall (2002) nos esclarece que é somente ao atravessarmos as fronteiras nacionais ou encontrarmos os estrangeiros que nos damos conta que as identidades nacionais não são coisas, ou seja, não são um atributo com o qual nascemos. As identidades nacionais são formadas e transformadas no interior de um sistema de representação. Parafraseando o exemplo de Hall (2002), nós só sabemos o que significa ser brasileiro devido ao modo como a "brasilidade" veio a ser representada. Ser brasileiro comporta um conjunto de significados construídos pela cultura nacional brasileira que possibilita participar da ideia de nação, e não somente adquirir o direito legal de uma nacionalidade. A nação não é apenas uma entidade política, mas algo que produz sentidos, o que quer dizer que é também um sistema de representação cultural. Uma nação é uma comunidade simbólica e é isso que explica seu poder para gerar um sentimento de identidade e lealdade.

Para avançar nessa discussão acerca das identidades nacionais, Hall lança mão de dois filósofos. Roger Scruton (1986) toma uma posição mais conservadora ao afirmar que a "condição de homem” faz com que o indivíduo exista e aja como um ser autônomo pelo fato de que tenha primeiramente se identificado com algo mais amplo, seja como membro de uma sociedade, grupo, classe, estado ou nação. Esse arranjo ao qual ele se identifica pode até não ter um nome, mas é reconhecido por ele como o seu lar. Já Ernst Gellner (1983) que assume uma posição mais liberal sobre o assunto, indica que o que decorre dessa ausência do sentimento de identificação nacional é da ordem de uma perda subjetiva.

A idéia de um homem sem uma nação parece impor uma (grande) tensão à imaginação moderna. Um homem deve ter uma nacionalidade, assim como deve ter um nariz e duas orelhas. Tudo isso parece óbvio, embora, sinto, não seja verdade. Mas que isso viesse a parecer tão obviamente verdadeiro é de fato, um aspecto, talvez o mais central, do problema do nacionalismo. Ter uma nação não é um atributo inerente da humanidade, mas aparece, agora, como tal. (GELLNER, 1983, p. 6) 
Com essas contribuições podemos analisar a jornada de Marjane em território estrangeiro. Ao mesmo tempo em que ela se apega à identidade iraniana ela recusa essa mesma identidade por não aceitar as mudanças políticas e religiosas de sua nação de origem, de seu lar. Por outro lado, não encontra em Viena nada que substitua esse sentimento de pertencimento que outrora vivera no Irã. Perde-se algo de si, algo pelo qual a personagem se esforça em recuperar.

Sozinha, numa cultura ocidental, Marjane, tenta estabelecer vínculos fixos, físicos, afetivos e simbólicos. Marjane tenta morar em vários locais até fixar residência na casa da Dra. Schloss, austríaca, professora aposentada de filosofia, que para ela, tinha cara de maluca. Nesse trajeto busca também possibilidades de estabelecer relacionamentos afetivos com alunos do colégio, com namorados, com um grupo de austríacos de Viena, sem muito êxito. No novo lugar a instabilidade afetiva e a insegurança em relação a quem ela é aparecem com frequência. Contudo, a comida simbólica ensaia dar um lugar conhecido e reafirmar um espaço perdido na memória de um território conhecido que ficou para traz.

\section{MESA PÓS-MODERNA}

O conceito de identidade pós-moderna na perspectiva de Stuart Hall (2002) considera a identidade desse tempo como fragmentada, provisória, por vezes contraditória, e que participa de um sistema de representação localizado em um espaço e um tempo simbólico. (HALL, 2002) Uma das possíveis leituras dessas mudanças, do ponto de vista político e econômico, tem sido associada ao processo de globalização e que reverbera numa identidade móvel e fluida, que atravessa fronteiras transnacionais, que é sensível a uma diversidade de estímulos e símbolos de outra cultura estrangeira e que está deslocada (fisicamente) de estruturas do passado como a família e o Estado, por exemplo.

Sobre as divergências culturais entre ocidente e oriente, Hall (2002) coloca o fenômeno da globalização provoca um efeito de homogeneização das identidades globais cujas características englobam: 1) um reforçamento das identidades locais; 2) a desigualdade própria ao processo que tem uma “geometria de poder" específica; 3)a retenção de alguns aspectos da dominação global ocidental que relativizam as identidades culturais pelo impacto 
da compressão espaço-tempo.13 Para Hall (2002), um dos exemplos mais importantes desse terceiro aspecto da homogeneização das identidades é o fenômeno da migração.

O movimento para fora (de mercadorias, de imagens, de estilos ocidentais e de identidades consumistas) tem uma correspondência num enorme movimento de pessoas das periferias para o centro [...] impulsionados pela pobreza, pela seca, pela fome, pelo subdesenvolvimento econômico e por colheitas fracassadas, pelos distúrbios políticos [...] as pessoas mais pobres em grande número acabam por acreditar na 'mensagem' do consumismo global e se mudam para os locais de onde vem os bens e onde as chances de sobrevivência são maiores. (HALL, 2002, p. 81)

O café do aeroporto da narrativa, o La Bagatelle, é a expressão de espaço do comer "em trânsito", o lugar do comensal em deslocamento, passageiro do mundo, numa viagem com pouso instável. A partir da concepção de comensalidade de Boutaud em que "a refeição e o sentar-se à mesa não proporcionam somente a ocasião de beber e de comer, mas também a de viver essa experiência em comum, de partilhá-la” (BOUTAUD, 2011, p. 1216), compreende-se o café cênico do filme. Como espaço contemporâneo, assim como os shoppings center e os hipermercados das megalópoles é também espaço da comensalidade pós-moderna, do sujeito deslocado, da comunidade sem lugar. (FREITAS, 2011, p. 20) O comer sozinho da personagem em território estrangeiro é também o espelho de um mundo onde o sujeito está deslocado de sua comunidade e fragmentado em sua identidade. $\mathrm{O}$ café do aeroporto, onde Marjane passa grande parte do tempo relembrando sua história, tem a cara desses ambientes universais, sem uma identidade definida. Uma identidade sem identificação, sem aproximação. Para onde se vai e de onde se vem... pouco importa.

O padrão asséptico desse tipo que você encontra em várias regiões do mundo, e que não quer que você fique por ali muito tempo, assim como os shopping centers, expressam esse caráter de pluralidade, não familiaridade,

13 Segundo Harvey (2004), a compressão espaço-tempo decorre da aceleração dos processos globais, um encurtamento do espaço pelo tempo eu pela velocidade que faz e com que achemos que o mundo é menor e as distâncias mais curtas. 
típicos da pós-modernidade. Sem afinidades que permitem que o sujeito se sinta em casa, acolhe temporariamente sujeitos, que assim como Marjane, se deslocam sozinhos no mundo. Não há identificação de quem passa ali, a regra é ser passageiro, transitório e não familiar. Assim como aqueles que ali transitam temporariamente e que escondem as discrepâncias e a complexidade e o isolamento do sujeito social.

O La Bagatelle é a própria expressão de inospitalidade contemporânea. "A construção dos Estados modernos não parece tampouco favorecer a hospitalidade, que, a partir de uma definição generosa, sobretudo religiosa, na idade média, submete o exilado a uma codificação regulamentada”. O comensal que compartilha o espaço da comida com Marjane faz parte dessas convenções sociais da sociedade migrante. Ninguém ali se conhece, todos estão de passagem, é o cenário da comensalidade da sociedade em trânsito. Por outro lado, esse espaço liberta o indivíduo de uma armadura simbólica da condição de não ser bem-vindo. Ali é o território daquilo que não é grupo, o estranho solitário é aceito. Não importa se a nacionalidade é russa, americana, alemã ou iraniana pra pedir um café. Como o território sem nação, ali ninguém é estrangeiro, ou melhor, ali todos são estrangeiros. O espaço menos xenófobo desses tempos, não está em jogo cultura nacional. Nem precisa conhecer a cultura local para pedir o café. Assim como nas grandes cadeias de fastfood mundo afora, mesmo sem falar nenhuma palavra em francês é possível reconhecer uma comida fastfood mundial.

\section{A VOLTA PRA CASA}

A narrativa ilustra a volta da personagem para um Irã que já não é mais o mesmo lugar de antes de sua partida. A trajetória da personagem é cheia de rupturas também. Ela rompe com suas crenças, com sua origem familiar, com sua condição de menina, com a perda de seus amigos, de pessoas queridas (seu tio), com a visão de mundo, com sua relação com Deus. No novo país, inicialmente ela percebe distâncias, estranhamentos e desafetos com a comensalidade e a cultura local. Por outro lado, a comida de sua memória do Irã remete a um lugar conhecido que, contudo, não existe mais. Ser iraniana, ou ser europeia: eis a questão que se coloca para a personagem que também se transformou. 
O cenário da comida do Irã, a pátria de Marjane, aparece quando a personagem está junto aos pais ou a família. Em contrapartida, no território estrangeiro, a personagem quase sempre está sozinha, séria, com expressão de desgosto. $\mathrm{O}$ espaço do comer no território estrangeiro pode ser lido também como uma representação de um lugar asséptico e solitário, a mesa de um restaurante, o balcão de um café, a rua...

Numa das cenas que selecionamos para análise, Marjane, após um período de exílio na Áustria, volta pra casa de seus pais, no Irã. ${ }^{14}$ Ao voltar, reconhece que muitas coisas não estão mais da mesma forma no país. No lar iraniano, ela tenta restabelecer os vínculos afetivos que deixou antes de partir, estabelecer um novo lugar; agora, não mais como criança ou adolescente, mas como uma jovem mulher iraniana. Esse retorno mostra uma tentativa de retomar a vida no Irã como alguém que viu o mundo do outro lado e já não cabe mais naquele espaço que lhe foi conferido no tempo passado, sobretudo diante do novo cenário político do Estado iraniano.

$\mathrm{Na}$ volta pro Irã, uma das primeiras coisas que Marjane faz é reencontrar a avó. A avó é uma figura fundamental de ligação entre Marjie ${ }^{15}$ e o Irã, assim como o chá que a avó lhe serve. ${ }^{16}$ A relação de Marjie com a avó e profundamente afetiva. Uma relação que tem cheiro, sabor e uma profunda coesão. O chá com a avó simboliza essa ligação. No reencontro, a avo pergunta como foi em Viena, Marjie apenas responde que "era diferente".

A comensalidade funciona como um signo de reconhecimento de pertencimento ou até mesmo seu contrário. $\mathrm{O}$ mesmo chá tomado em Viena, com a senhora austríaca, aposentada ou no Irã, com a sua avó, tem sabores completamente diferentes. A relação é outra, o afeto é outro, o prazer é outro. Neste sentido, a comida tem outro sabor. A comensalidade aqui não se dá pelo aspecto nutritivo, mas sim profundamente ligado a memória e a subjetividade da personagem.

Outra questão importante a ser considerada são as ligações que a personagem estabelece afetivamente, as identificações. Marjie tem, por exemplo, muito mais ligação com a avó do que com os pais. A lembrança e a saudade estão bem mais relacionadas à relação com a avó, do que com a mãe. A avó é

\footnotetext{
14 Cena em 00:52:35.

15 Marjie como diminutivo de Marjane.

16 Cena em 00:54:54.
} 
a sua referência existencial principal, é o seu exemplo de vida, seu modelo de existência livre e feliz, é um contraponto a tudo o que ela quer ser e ainda não consegue, mas a avó é um pilar de sua personalidade e modo de ver o mundo.

Nesse sentido não podemos deixar de considerar a importância das identificações narcísicas na formação da identidade. Desde muito cedo somos habituados a nos reconhecermos a partir de um nome e passamos a responder por ele, marcando assim um ponto indiscutível de inserção cultural. Onde quer estejamos vivendo, a princípio nosso nome nos acompanha, sendo através dos laços identitários que o indivíduo forma sua identidade.

\begin{abstract}
De modo imperioso, na comunhão familiar, e posteriormente nas diversas instituições culturais, é nos apresentado os ideais identitários encarnados em determinados ícones. Nós nos identificamos com eles. Mais que isso: a partir dessas coordenadas idealizadas moldamos nosso desejo, nos engajamos em determinado grupo social, comunidade, crença. (STARNINO, 2016, p. 231)
\end{abstract}

Noutra cena, no mesmo café La Bagatelle do aeroporto de Orly (Paris), Marjane já não precisa usar burca, fuma e sozinha, misturada aos outros cidadãos do mundo ou solitários em trânsito, ela relembra sua história. O lugar lhe parece tão familiar quanto a mesa caseira do Irã. Marjane é mais uma. Ao tentar entrar no Irã, voltando da Áustria, a mulher do guichê de embarque pede o passaporte de Marjie, mesmo ela estando de burca, ${ }^{17}$ a guarda do controle de passaportes pergunta se ela tem na mala filmes, moda, pornografia, carne de porco, álcool, baralho de carta, música, representações muito comuns no universo cultural do mundo ocidental que não devem "invadir” o Irã, no olhar do estado repressor. Só é possível estranhar e entender o próprio espaço quando se conhece um outro lugar.

\title{
"NAQUELE TEMPO EU TINHA UMA VIDA TRANQUILA. EU COMIA BATATAS FRITAS COM KETCHUP..."
}

A comida também é recurso de memória de uma garota que atravessa oceanos, é um código que faz ponte entre o espaço que ficou no passado e não

17 Cena em 00:02:56. 
consegue estabelecer um apoio com o território presente. Marjane relembra um dos períodos mais críticos de repressão no Irã, antes de Marjane ir morar na Europa pela primeira vez. É a memória de quando ela e a avó jogam fora, no vaso sanitário do banheiro de casa, o conteúdo de várias garrafas de vinho de seu pai, antes que a polícia fizesse uma vistoria em sua casa.18 Em contraste, Marjane também relata os períodos mais democráticos de seu tempo ainda criança, no Irã, quando nas festas em sua casa, havia bebida, comida, música e conversas de forma liberada.19 Marjane lembra que seu tio20 tinha se tornado um produtor clandestino de vinho com a ajuda de sua faxineira, Sra. Naslin. O vinho na mesa muçulmana é uma proibição antiga, o que remonta a questão de conflitos e oposição à cultura cristã do inimigo cristão. Consumir o vinho naquele contexto era também uma possibilidade de ser contra ao poder fundamentalista muçulmano daquele momento. Beber o vinho era também desmoralizar as regras do Estado e compactuar com a cultura. Era um tempo também quando ela comia Ketchup e batatas fritas com liberdade, sem que isso fosse motivo de repressão ou um ataque ao poder de um Estado que não é laico. É repressor e impunha as regras também da comida, cerceando as referências da cultura consumista americana. As guerras atingem também aquilo que se come. Comer a comida do inimigo é uma afronta. Beber o vinho do católico é uma heresia. A comida vai, pouco a pouco, revelando essas relações que estão veladas no espaço social.

Perdida em reminiscências, Marjane relembra o tempo que finalmente encontrou um rapaz por quem se apaixonou e que parecia tecer um laço afetivo. Contudo, num determinado dia, ela descobre esse rapaz com outra menina, bastante frustrada e afetivamente desiludida ela perambula pela rua, meio sem rumo. Então, do lado de fora da Confeitaria Sacher,21 Marjane observa a vitrine e encontra a tão falada "torta Sacher”. Num momento de solidão a comensalidade imaginária, traz de volta a figura do pai, a casa, o

\footnotetext{
18 Cena em 00:27:07.

19 Cena em 00:26:02.

20 Cena em 00:26:02.

21 Famosa e uma das mais antigas confeitarias da Áustria, datada do século XIX. A Torta Sacher que é ali produzida, foi inicialmente confeccionada por um nobre confeiteiro austríaco Franz Sacher, em 1832 e é hoje uma das tortas mais famosas do mundo. Tem sua receita original até hoje preservada e é um símbolo da história da culinária e da nobreza austríaca. Ver: https://www.sacher.com.
} 
afeto, o aconchego mesmo que a torta nem tenha sido comida. Esse efeito se deve ao fato que na sua partida para Viena, no aeroporto do Irã o pai de Marjie aconselha que ela assim que chegar a Viena coma a "torta Sacher" e descreve a torta como um bolo de chocolate extraordinário. Marjane olha o pai com uma cara de profunda apreensão e tensão.22 A mãe complementa então que depois eles irão visitá-la. Marjane tenta contestar, mas o pai fala que já chega e que ela deve ir. Aconselha então a menina para que ela nunca se esqueça de onde vem e de quem ela é. A “torta Sacher", apesar de conhecida mundo afora, causa apenas estranheza na menina. Comer a torta e saborear o gelo e a distância da Áustria na menina.

Marjane e a torta parecem ter pouca afinidade. A iguaria austríaca não evoca afinidade, nem o desejo de comer, mas a carga simbólica, de uma saudade que preencha a solidão e faça um vínculo com a memória afetiva do pai. Marjane continua então sua perambulação e acaba comendo um sanduíche que ela pegou numa lata de lixo. O cinema é dotado dessa capacidade de remeter a sensações afetivas nas narrativas, assim como exacerbar o contraste entre a comida afetiva e a comida-lixo que se apresentam nessa sequência de cenas. A comida nesse filme é usada permanentemente para marcar o tempo e as referências presentes e perdidas, antigas e novas, as dúvidas e as certezas. $\mathrm{O}$ valor afetivo ligado ao saber tem um caráter atemporal e que ao mesmo tempo atualiza e dá vivacidade a uma lembrança, possibilitando até mesmo ressignificar uma experiência vivida.

Nesse sentido, quando falamos de gosto não nos referimos somente aos sabores identificados pelas papilas gustativas, que falam ao corpo biológico. Os sabores que o filme apresenta são sabores recheados, simbolizados. São sabores que falam diretamente com a alma.

\section{TOMANDO CHÁ COM O BÁRBARO}

Na etimologia da palavra, bárbaro vem do grego Bá $\rho \beta \alpha \rho o \varsigma$, quer dizer estrangeiro, não grego, em oposição; relativo a estrangeiros; incorreto, grosseiro, não civilizado, cruel. (MACHADO, 1956) A condição de exílio expressa também a experiência de alteridade, da confrontação com o outro no que ele tem de mais estranho em nós e muitas vezes bárbaro. Na casa de Frau doctor

22 Cena em 00: 35:16. 
Schoss, a austríaca que recebe a estrangeira para morar, as duas tomam um chá (40“35`). O chá aqui remete à hospitalidade com o estrangeiro,23 diferentemente daquele que Marjane bebe com a avó ao retornar para casa. Ali representa um acolhimento de reconhecimento. A linguagem de recepção entre Marjane e a senhora austríaca passa pela comida, o chá é o símbolo ou o código conhecido e o elemento que tenta fazer a ligação quando não se conhece outros códigos, como por exemplo, o idioma. (APRILE, 2004, p. 1045) Apesar do chá, Marjane não se sente acolhida.

Nessa chegada, Marjane decidiu tentar entender a cultura ocidental, leu várias obras da cultura austríaca, porém, afirma que para ela algumas coisas seriam impossíveis, como o costume austríaco, por exemplo, de beber juntos e brindarem com canecas enormes de cerveja, vestidos com trajes típicos da Áustria.24,25 Marjane, no entanto, explica, que entendeu que algumas coisas da cultura austríaca, nunca seriam realmente entendidas por ela. Beber a cerveja austríaca em copos grandes com as roupas típicas faria dela uma austríaca? Usar a burca e tomar chá fará dela uma iraniana de verdade?

Numa tentativa de fugir aos estereótipos sobre sua cultura, ela então inventa ser francesa. Numa cena num bar, um rapaz pergunta de onde ela vem e Marjane diz ser francesa. Logo vai embora e inicia um diálogo nos pensamentos com a avó imaginária. A avó a questiona por que negou que era iraniana. E ela rebate a avó dizendo, "Você acha que é fácil ser iraniana aqui? Quando digo de onde sou, me olham como se fosse selvagem. Pois para eles somos fanáticos que passam o tempo gritando e brigando". A avó questiona então, "Você acha que isso e um motivo para negar suas origens?" E complementa: "Você se lembra do que eu tinha dito? Seja integra com você mesma”. Esta cena apresenta de modo explícito o conflito de Marjane sobre não ser nem iraniana, nem austríaca e tampouco francesa.

O filme é uma representação de um mundo possível, situada em um contexto específico, e que pode ser entendida quase sempre como uma narrativa singular de um momento histórico ou de um drama pessoal. Para

\footnotetext{
23 Cena em 00:40:54.

24 Em algumas regiões da Áustria é costume se vestir com trajes da região nos encontros e festas, o chamado Trachtenkostüm. O mais conhecido é a roupa tirolesa, mas há outras também. Ver: https://www. wissen.de.

25 Cena em 00:41:05.
} 
Aumont (1993, p. 248), “Toda representação é relacionada por seu espectador, ou melhor, por seus espectadores históricos e sucessivos, a enunciados ideológicos, culturais, em todo caso simbólicos, sem os quais ela não tem sentido”. Assim, a cena acima busca capturar o espectador no drama vivido por Marjane, uma vez que ele é o drama vivido por muitos outros imigrantes que em fuga buscam um lugar para reconstituir suas vidas. Mas além dos imigrantes, a cena revela uma questão identitária que é própria ao mundo contemporâneo, mas que em virtude da gravidade das situações dos imigrantes, ganham voz e intensidade nesses personagens. Atualmente, somos todos imigrantes.

Após essa cena, Marjane relembra outro momento, quando ela estava num restaurante comendo sozinha e escuta por acaso a conversa da irmã do rapaz que ela conheceu no bar com outras meninas que falam a seu respeito: Sabe o que ela disse ao meu irmão? Que era francesa. Imagina, já viu a cara dela? Quem acredita que é francesa? Marjane então se irrita e vai até elas e gritando diz que ela é iraniana sim e que se orgulha disso.

Como um espaço de tomada de demonstração, de integração e exclusão, de hierarquização, Albert (2011) apresenta elementos que consideram a mesa como uma das ferramentas políticas mais sutis da sociedade. Além disso, ali seria um lugar particular de sociabilidade e de exteriorização de etiquetas e regras sociais intrínsecas. Entretanto, o comer sozinho, ofereceria igualmente outra leitura política da mesa, aquela da falta de socialização pelo isolamento e, portanto, a exclusão do grupo ao qual supostamente pertencemos. A história mostra que ao lado das grandes ágapes de poder, dentro de palácios principescos, existiram várias comensalidades desde as rígidas até as mais revolucionárias, ao ar livre como os piqueniques dos grevistas de junho de 1936, que consagraram novas modalidades de contestação do poder vigente.

Tênis, música de Michael Jackson, ritmo punk, baralho de cartas, jaqueta, garrafa de vinho, gravata, elementos simbólicos que vão de encontro ao universo repressor do Estado iraniano, que impõe seus próprios símbolos: uma chave do paraíso, uma burca, uma arma aos jovens. Nesse lugar, o passaporte é a peça-chave na entrada e saída das barreiras alfandegárias. É o símbolo que identifica e garante o deslocamento oficial dos sujeitos contemporâneo. Essa condição de poder estar em trânsito, é também uma condição de liberdade de poder ir e vir, uma suposta condição de liberdade poder sair do teto 
das estruturas do Estado, da família, mesmo que isso não seja possível para todos. Marjane representa e esse sujeito em trânsito: Sai do Teerã e vai para Viena. Sai de Viena e volta ao Teerã. Sai do Teerã e vai para França. Em solo europeu, Marjane é colorida, usa vermelho e tem os cabelos soltos. No Teerã, Marjane é preto e branco, veste uma burca e o cabelo está preso. Ela percebe que comer só na Europa é diferente de comer só em Teerã.

Persépolis utiliza símbolos para contar histórias, a história do homem que migra é também uma história que busca símbolos para construir identidades tradicionais ou modernas, ocidentais ou orientais. Sociedades mais repressoras e outras mais consumistas. O filme como linguagem que tenta ser universal, utiliza-se desses elementos com bastante propriedade. $\mathrm{O}$ espaço do aeroporto, a torta Sacher, as festas e o ritual de beber o chá foram elementos que ajudaram a olhar e perceber como a comensalidade expressa aspectos que identificam ou que excluem os sujeitos migrantes no mundo pós-moderno dos deslocamentos geográficos, culturais e identitários.

Contradizendo o discurso de uma comunidade global, o espaço da comensalidade estrangeira expressa uma releitura do bárbaro contemporâneo. A globalização, seus fluxos e tudo que ela comporta de desumanização é o bárbaro por excelência, com o qual somos cotidianamente convocados a tomar um chá. Assim como o chá da austríaca que recebe Marjie, o mundo contemporâneo nos espreita com a certeza de que vamos falhar e seremos pegos. Mas pegos em quê? Em nossa mais profunda fraqueza, a fraqueza de sermos humanos.

\section{REFERÊNCIAS}

ARIÉS, P. Les fils de McDo: la MacDonalidisation du monde. Paris: L'Harmattan, 1997.

ALBERT, J. M. Às mesas Mesas do poder: dos banquetes Gregos ao Eliseu. São Paulo: Senac, 2011.

APRILE, S. Mutações e Transferências. In: MONTADON, A. O livro da hospitalidade: acolhida do estrangeiro na história e nas culturas. São Paulo: Senac, 2004.

p. 1039-1050.

AUMONT, J. A imagem. Campinas: Papirus, 1993.

BAUER, M. W.; GASKELL, G. Pesquisa qualitativa com texto, imagem e som: um manual prático. Petrópolis: Vozes, 2011. 
BAUMAN, Z. Estranhos a nossa porta. Rio de Janeiro: Zahar, 2017.

BOUTAUD, J. J. Compartilhar a mesa. In: MONTADON, A. O livro da hospitalidade. São Paulo: Senac, 2011. p. 1213-1230.

DUBAR, C. La socialization: construction de identités sociales et professionnelles. Paris: Armand Colin, 2002.

FREITAS, R. F. Comunicação e espaços urbanos de consumo: o imaginario dos shoppping centers. In: FREITAS, R. F.; OLIVEIRA, J. D. Olhares urbanos: estudos sobre a metrópole comunicacional. São Paulo: Summus, 2011. p. 13-25.

GELLNER, E. Nations and Nationalism. Oxford: Blackwell, 1983.

HALL, S. A identidade cultural na pós-modernidade. Rio de Janeiro: DP\&A, 2002.

HARVEY, D. Condição pós-moderna. São Paulo: Edições Loyola, 2002.

HOLANDA, A. B. Mini Aurélio: o dicionário da lingua portuguesa. Rio de janeiro: Positivo, 2010.

MACHADO, J. P. Dicionario etimologico da lingua portuguesa com a mais antiga documentação escrita e conhecida de muitos dos vocabulos estudados. Lisboa: Confluencia, 1956.

MACKEY, S. Os Iranianos. Rio de Janeiro: Biblioteca do Exército, 2008.

PERSÉPOLIS. Direção: Marjane Satrapi, Vincent Paronnaud. Produção: MarcAntoine Robert, Xavier Rigault. Interprete: Chiara Mastroianni, Catherine Deneuve, Danielle Darrieux. Roteiro: Marjane Satrapi, Vincent Paronnaud. França: EUROPA FILMES, 2007. (95 min).

PRADO, S. D.; FERREIRA, F. R.; CARVALHO, M. C. et al. Cinema e Diversidade nos modos de Olhar a Comensalidade contemporanea. In: PRADO, S. D.;

FERREIRA, F. R.;

CARVALHO, M. C. et al. Cinema e Comensalidade 2. Curitiba: CRV, 2017. p. 17-27.

SAYAD, A. O que é um imigrante. In: SAYAD, A. Imigração ou os paradoxos da alteridade. São Paulo: Universidade de São Paulo, 1998.

STARNINO, A. Sobre identidade e identificação em psicanálise: um estudo a partir do Seminário IX de Jacques Lacan. Doipontos, São Carlos, v. 13, n. 3, p. 231-249, 2016 .

SCRUTON, R. Authority and allegiance. In: DONALD, J.; HALL, S. (org,). Politics and Ideology. Milton Keynes: Open University Press, 1986. p. 17-37.

WOLLZ, L. E.; DONIZETE PRADO, S. Cinema e comensalidade: aspectos simbolicos da comida a partir da lingugem cinematografica. In: VARGAS, E. P.; CARVALHO, V. S.; FERREIRA, F. R. et al. Cinema e Comensalidade. Curitiba: CRV, 2017. p. 37-51. 


\title{
"EU SOU UM PETISCO CARIOCA!" CORRELAÇÕES ENTRE O BISCOITO GLOBO, A IDENTIDADE E O IMAGINÁRIO DO RIO DE JANEIRO ${ }^{1}$
}

\author{
ALESSANDRA DE FIGUEREDO PORTO \\ CÍNTIA SANMARTIN FERNANDES
}

\section{INTRODUÇÃO}

De acordo com matéria intitulada "Ser carioca vai além de nascer no Rio de Janeiro, é um estado de espírito", (CAPUCCI, 2015) ser carioca é: "Biscoito, mate, água... ó ó biscoito! É a cara do Rio. Biscoitinho de polvilho!” Nesse contexto, a famosa rosquinha de polvilho passou a ser presença marcante em Copacabana e nas demais praias do Rio de Janeiro, bem como em vários locais espalhados pela cidade - até mesmo nos enormes engarrafamentos que assolam a capital fluminense. Também representa uma marca que remete à "carioquice", já que os produtos e demais souvenirs que carregam a identidade visual do Biscoito Globo evocam o estilo carioca de ser, suscitando as memórias, as lembranças e o imaginário de uma cidade que

1 O capítulo é parte integrante da pesquisa de doutorado de Alessandra de Figueredo Porto realizada no Programa de Pós-Graduação em Comunicação da Universidade do Estado do Rio de Janeiro sob orientação da professora Dra. Cíntia Fernandes. 
resiste às mazelas - e ainda permanece sendo definida como "maravilhosa". Compreender as subjetividades abarcadas pelo Biscoito Globo, bem como o que o faz ser visto como referência importante da cultura carioca é o objetivo do presente artigo. (BISCOITO..., 2019)

\section{BREVE HISTÓRICO DO BISCOITO GLOBO: A ROSQUINHA QUE QUASE SE CHAMOU “COPACABANA”}

O "pai" da tradicional rosquinha de polvilho chama-se Milton Ponce. Ele faleceu aos 78 anos no dia 18 de maio de 2017, em decorrência de um câncer. ${ }^{2}$ (MORRE..., 2017) Apesar de ter se tornado um ícone da cidade do Rio de Janeiro, o Biscoito Globo nasceu em solo paulista. (MANIER, 2017) A história da rosquinha de polvilho começou no ano de 1953, em virtude da separação dos pais de Milton: Antonio Ponce Morales e Encarnação Fernandes. O casal vivia na capital paulista com os quatro filhos: Aparecida, João, Jaime e Milton Ponce. Após o término do casamento, Antonio ainda tinha esperanças de reatar a união. Mas as suas expectativas foram em vão. Desse modo, Antonio Ponce seguiu para Franca - cidade paulista situada a $401 \mathrm{~km}$ da capital - com três dos seus quatro filhos, visando recomeçar a vida. Jaime (o mais velho) estava em outra cidade do interior paulista servindo ao Exército, e não acompanhou o pai e os irmãos. Porém, as coisas não saíram como Antonio planejara. Diante das dificuldades para sobreviver com os três filhos em Franca, Antonio resolveu voltar para a cidade de São Paulo com Milton e João. Aparecida permaneceu em Franca na casa de tios, e posteriormente Encarnação foi buscá-la.

Mas Antonio permanecia desolado, já que não aceitava o término do seu casamento. Enquanto isso, as dificuldades aumentavam diariamente na vida de Milton e João. A situação dos irmãos só piorava, e era preciso garantir a sobrevivência na capital paulista. Milton estava preocupado com o futuro de João, seu irmão caçula. Sendo assim, Milton resolveu pedir auxílio a um primo, conforme cita Manier (2017, p. 40).

2 Ver: https://extra.globo.com/noticias/rio/morre-milton-ponce-um-dos-donos-do-biscoito-globo-aos-78-anos-21358206.html. 
Foi nesse momento de desespero e necessidade de uma decisão que Milton se lembrou de um primo, Germano Felippe. Era mais velho, morava no Ipiranga e tinha uma padaria anexa à casa: Padaria Record. Talvez o primo Germano lhes desse abrigo. Talvez ele e João pudessem ficar lá e ajudar de alguma forma para compensar as despesas.

Germano ficou sensibilizado com a situação dos primos, e deu abrigo aos irmãos Ponce. Milton e João começaram a trabalhar juntos na Padaria Record, e Germano ensinou aos primos como fazer biscoitos de polvilho. E assim nasciam os "Biscoitos Felippe” - em homenagem ao patrão, que se chamava Germano Felippe. Manier (2017) menciona que a produção dos "Biscoitos Felippe” alcançava 50 a 60 quilos por dia. Eram vendidos a peso na Padaria Record, bem como por ambulantes em vários pontos da "terra da garoa”, bem como em outras cidades paulistas - incluindo a Praia de Santos, no litoral. Como ainda não chegara a oportunidade de comercializar o produto no Rio de Janeiro, Milton e João vendiam os biscoitos de modo laborioso na capital paulista. ${ }^{3}$ (BISCOITO..., 2019) Trabalhando como ambulantes, os irmãos Ponce integravam a força de vendas que incrementava a distribuição dos biscoitos. Canais de informação entre a Padaria Record e os consumidores, os ambulantes cobriam grandes quilometragens diárias vendendo o produto, batiam papo com os fregueses e circulavam a todo o momento com notícias frescas sobre o que acontecia na cidade e no país, trazendo também ideias para incrementar as vendas dos biscoitos. (MANIER, 2017)

Os "Biscoitos Felippe" se tornaram o faturamento excedente da Padaria Record. Era início da década de 50, e o então presidente Getúlio Vargas havia solicitado verba para a realização do $36^{\circ}$ Congresso Eucarístico Internacional, megaevento realizado no Rio de Janeiro dos "anos dourados". Para Freitas, Lins e Santos (2016), um evento pode ser classificado como mega a partir de seu impacto na mídia antes, durante e depois da sua realização. Partindo de tal premissa, o megaevento $36^{\circ}$ Congresso Eucarístico 
Internacional foi considerado uma injeção de ânimo para o turismo no país, como se observa a seguir. ${ }^{4}$

No dia 4 de fevereiro de 1953, o presidente Getúlio Vargas enviou mensagem ao Congresso Nacional, acompanhada de projeto-lei, solicitando a abertura de crédito de Cr\$ 14 milhões pelo Ministério das Relações Exteriores para atender as despesas com o $36^{\circ}$ Congresso Eucarístico Internacional, a realizar-se em julho de 1955, no Rio. Na exposição de motivos, o ministro da Fazenda apresentou as diversas razões invocadas pelo cardeal dom Jayme Câmara para a concessão desse auxílio, inclusive o reflexo do certame no movimento turístico para o Brasil. (EM 1955..., 2016)

Classificado como um megaevento de caráter religioso, o $36^{\circ}$ Congresso Eucarístico Internacional mobilizava o governo e a sociedade da década de 1950, já que propunha várias inovações e mudanças na cidade do Rio de Janeiro para que viesse a acontecer. Na ocasião, o megaevento reiterou a forte vocação católica da cidade: "Em 1955, realizou-se um Congresso Eucarístico Internacional no Rio de Janeiro, espetáculo de fé, como foi chamado pela imprensa, que fortaleceu as tradições cristãs na cidade”. (TURAZZI, 2014, p. 56)

Para que aconteçam -seja antes, durante e após a sua realização-, os megaeventos alteram o cotidiano de uma cidade. Sendo assim, os irmãos Ponce enxergaram o megaevento $36^{\circ}$ Congresso Eucarístico Internacional como uma oportunidade de negócios, e resolveram comercializar os biscoitos no Rio de Janeiro em 1955. Visando preparar a cidade para o congresso, foram executadas várias construções no Rio de Janeiro, conforme enumerado a seguir. ${ }^{5}$

O encontro [...] motivou a realização de grandes obras, como a ampliação da adutora do Guandu e parte do aterramento do Flamengo, onde futuramente surgiriam o Parque do Flamengo e o Monumento aos Pracinhas. A primeira fase do aterramento,

4 Ver: http://acervo.oglobo.globo.com/em-destaque/em-1955-36-congresso-eucaristico-fez-do-rio-capital-mundial-do-catolicismo-9123322

5 Ver: http://acervo.oglobo.globo.com/em-destaque/em-1955-36-congresso-eucaristico-fez-do-rio-capital-mundial-do-catolicismo-9123322 
entre a Rua Santa Luzia e o Passeio Público, foi transformada na Praça do Congresso. Ali, em confessionários improvisados, fiéis de todo mundo podiam contar seus pecados e receber a absolvição. (EM 1955..., 2016)

O $36^{\circ}$ Congresso Eucarístico Internacional aconteceu entre os dias 17 e 24 de julho de 1955 na cidade do Rio de Janeiro. ${ }^{6}$ (TRÂNSITO..., 1955) Uma imagem de Nossa Senhora Aparecida veio de trem do Santuário de Aparecida do Norte - cidade localizada no interior paulista - especialmente para o Congresso. ${ }^{7}$ (60 ANOS..., 2015) Com o suicídio do presidente Getúlio Vargas em 1954, quem proferiu a "Saudação aos peregrinos do XXXVI Congresso Eucarístico Internacional” foi o presidente Café Filho.

Durante a realização do $36^{\circ}$ Congresso Eucarístico Internacional, as vendas da rosquinha de polvilho superaram as expectativas dos irmãos Milton e João Ponce. Empolgados com o sucesso do produto durante o megaevento - e com base no êxito obtido em São Paulo -, os irmãos Ponce anteviram que o Rio de Janeiro seria o mercado ideal para os biscoitos de polvilho. ${ }^{8}$ (BISCOITO..., 2019) Partindo das experiências vividas no tempo em que ainda eram ambulantes no litoral paulista, os irmãos Ponce perceberam que, "diferentemente dos paulistas, que iam à praia e queriam se alimentar, os cariocas eram mais descontraídos e não ligavam para fazer refeições; queriam apenas beliscar”. (MANIER, 2017, p. 48)

A partir de então, Milton e João começaram a produzir as rosquinhas no bairro carioca de Botafogo, juntamente com o primo Germano. ${ }^{9}$ (CASARIN, 2017)

Ao chegar, ainda em 1955, os rapazes e o primo alojaram-se na pensão de um casal de portugueses, em Botafogo - a mesma onde os vendedores haviam se hospedado durante o Congresso Eucarístico -, ocupando quartos com beliches, banheiro no final do corredor e trocando o bom e costumeiro arroz com feijão

6 Ver:http://memoria.bn.br/DocReader/Hotpage/HotpageBN.aspx?bib=089842_06\&pagfis=50201\&url= http:// memoria.bn.br/docreader\#

7 Ver: http://arqrio.org/formacao/detalhes/816/60-anos-do-congresso-eucaristico-do-rio

8 Ver: https://www.biscoitoglobo.com.br/

9 Ver:https://paginacinco.blogosfera.uol.com.br/2017/01/18/voce-sabia-que-o-biscoito-globo-icone-do -rio-de-janeiro-nasceu-em-sao-paulo-e-o-que-mostra-biografia-do-quitute/ 
paulistano pelo típico bacalhau com batatas lusitano em rios de azeite. (MANIER, 2017, p. 53)

Em 1965, passados dez anos após a realização do $36^{\circ}$ Congresso Eucarístico Internacional e da chegada dos rapazes ao Rio de Janeiro, Milton Ponce tinha outro sócio na fabricação dos biscoitos: o português Francisco Torrão. Germano Felippe (seu primo) havia saído da sociedade. Foi no ano de 1965 que o Rio de Janeiro comemorou 400 anos. Cabe registrar que, em abril de 1960, o antigo Distrito Federal assumiu a condição de estado da Federação, com o nome de Estado da Guanabara, passando a ser administrado por governadores, fazendo com que o Estado da Guanabara tivesse simultaneamente o perfil de cidade-estado e de cidade-capital. ${ }^{10}$ (DO ESTADO..., 2015) Ou seja, o Estado da Guanabara já nasceu com praticamente quatro séculos, como explica Mesquita (2014, p. 87-88).

Na condição de cidade-estado, a Guanabara nasceu quase quatrocentona, pois no ano em que se comemorava o quarto centenário da cidade, o Estado completava apenas cinco anos de existência. Criada pela Lei San Tiago Dantas em 12 de abril de 1960, a Guanabara já surgiu com a marca de cidade-capital - assim definida pelo caráter pedagógico de modelar comportamentos e inculcar valores associados a um projeto de nação - e predestinada a ser cosmopolita, na medida em que a cidade que lhe deu origem foi sucessivamente sede da capitania do Rio de Janeiro; capital do Brasil colônia (1763-1808); Corte do Reino de Portugal (18081816); capital do Brasil imperial (1822-1889); e sede do Brasil republicano (1889-1960).

A condição de cidade-estado perdurou até março de 1975, quando houve a fusão entre os estados do Rio de Janeiro e da Guanabara, enquanto a cidade do Rio de Janeiro, como capital do novo estado, ganhou status de município, voltando a ser administrada por prefeitos. Se para alguns essa medida era mais um indício da perda de prestígio do Rio no cenário nacional -iniciada com a transferência da capital federal para Brasília-, para

10 Ver: http://multirio.rio.rj.gov.br/index.php/estude/historia-do-brasil/rio-de-janeiro/71-um-rio-de-mu-itos-janeiros/3365-a-fusao-do-estado-da-guanabara-ao-estado-do-rio-de-janeiro 
outros, a fusão seria o ponto de partida para uma nova fase de desenvolvimento econômico e social. ${ }^{11}$ (UM RIO..., 2015)

Retornando ao ano de 1965, vale frisar que, em decorrência das comemorações do IV Centenário da cidade, o Rio de Janeiro viveu um tempo ímpar de transbordamento de memória. (MESQUITA, 2014) E em meio a esse momento de expressão cultural e de reafirmação da identidade do Rio de Janeiro, os irmãos Ponce finalmente tinham começado a prosperar com a venda das rosquinhas de polvilho, dez anos após o início da sua fabricação no bairro de Botafogo. Jaime - o irmão que estava servindo ao Exército quando Milton e João foram para São Paulo ainda crianças - também viera para o Rio. Na ocasião, os rapazes demonstravam o desejo de adquirir uma panificação falida localizada no centro da cidade do Rio de Janeiro. Porém, João começou a trabalhar em outra empresa, e ficou com receio de ingressar no negócio. Mas ainda no ano de 1965, o português Francisco Torrão entrou na sociedade para substituir João. E com a entrada de Torrão, Milton e o irmão Jaime adquiriram a Panificação Mandarino, razão social do Biscoito Globo até hoje.

$\mathrm{Na}$ época, os cariocas já degustavam o petisco de polvilho em vários locais, e "os biscoitos, que faziam sucesso nas praias, eram agora conhecidos em toda a cidade". (MANIER, 2017, p. 63) Todavia, um problema persistia. O produto ainda se chamava "Biscoitos Felippe", e era reconhecido como os "biscoitos paulistas". Desse modo, era necessário criar um nome que tivesse identificação com os cariocas. Como os irmãos Ponce trouxeram as rosquinhas de polvilho para o Rio de Janeiro em 1955 "com excelente receptividade por parte do povo, o ideal seria um nome que os identificasse como cariocas: Biscoito Copacabana pareceu uma ótima solução”. (MANIER, 2017, p. 64) Mas a ideia não seguiu adiante, pois uma confeitaria da cidade serrana de Petrópolis $(\mathrm{RJ})$ já era detentora da marca. Como o nome de fantasia da panificadora que havia adquirido era "Padaria Globo", Milton Ponce não titubeou: batizou o polvilho de Biscoito Globo. E com o passar dos anos, o Biscoito Globo ganhou uma bebida como acompanhamento: o mate - assunto a ser tratado no tópico a seguir. 


\section{E PARA ACOMPANHAR A ROSQUINHA DE POLVILHO? MATE COM LIMÃO}

Chegando ao século XXI, a "dupla mate e biscoito de polvilho" é percebida como "a mais carioca possível”, uma vez que ao passear pelas praias do Rio, não há quem não reconheça os vendedores desses produtos, cada um com seu jeito próprio de atrair a freguesia. ${ }^{12}$ (ARAÚJO, 2014) Vale destacar que nas praias cariocas:

A variedade de produtos vendidos é enorme: água mineral, água
de coco, refrigerantes, cerveja, mate, refrescos, sucos, batidas,
sanduíches, biscoitos, empadas, pastéis, queijo coalho na brasa,
camarão frito, churrasquinho, frutas, ostras, cuscuz, bijuterias,
artesanato, cosméticos [...], roupas (cangas, batas, saias, vesti-
dos, chapéus e bonés, óculos, bolsas, redes, mantas, brinquedos...
(CORRÊA, 2009, p. 152)

Em relação à venda de produtos como o camarão frito e o queijo coalho, cabe frisar a proibição da Guarda Municipal do Rio de Janeiro referente à comercialização de alimentos perecíveis. ${ }^{13}$ (GRUPAMENTO..., 2010) No ano 2000, visando fiscalizar a orla carioca de modo mais ostensivo, a Guarda Municipal do Rio de Janeiro criou o Grupamento Especial de Praia (GEP), "com a missão de patrulhar as praias da Zona Sul, desenvolvendo ações de assistência a banhistas e frequentadores em geral". (GRUPAMENTO..., 2010) ${ }^{14}$ Em 2011, a atuação do GEP também foi estendida para a orla da Zona Oeste.

Alheios às ações do GEP, ainda é possível ver ambulantes exibindo seus fogareiros de queijo coalho e espetinhos de camarão regados a limão pelas areias das praias cariocas. Mas apesar da farta oferta de produtos, a "dupla mate e biscoito de polvilho" possui local de destaque junto aos frequentadores das praias cariocas. E para compor a dupla, existe outra bebida: a limonada. Juntamente com o mate, a limonada é vendida em galões pelos ambulantes por toda a extensão da orla carioca para acompanhar os biscoitos de polvilho. É interessante observar que, assim como a água de coco, a limonada era uma

\footnotetext{
12 Ver: http://www.multirio.rj.gov.br/index.php/leia/reportagens-artigos/reportagens/913-patrimonio-imaterial-carioca-vendedores-de-mate-e-biscoito-de-polvilho

13 Ver: http://prefeitura.rio/web/gmrio/especial-de-praia

14 Ver: http://prefeitura.rio/web/gmrio/especial-de-praia
} 
bebida muito requisitada e vendida pelas negras de ganho no Rio de Janeiro do século XIX. (PRIORE, 2016) E no ano de 2015, a limonada foi "gourmetizada” por alguns ambulantes nas praias cariocas, conforme publicado na coluna "Gente Boa” (jornal O Globo): "Gourmetizaram a limonada da praia. O bom e velho limão, companheiro do mate, estava sendo anunciado nas areias de Ipanema como 'limonada suíça' por um vendedor da bebida em galão". ${ }^{15}$ (GUIMARÃES, 2015) Cabe registrar que o conceito de gourmetização deve ser entendido aqui como o processo intencional de sofisticação e exclusividade de um produto, uma forma de diferenciar o que é preparado de modo tradicional, relacionando um produto com a ideia de requinte. (PALMIERI JÚNIOR, 2017)

Com ou sem "gourmetização", a limonada chegou ao século XXI como uma bebida tradicional na orla carioca. Desse modo, "o trio: biscoito de polvilho + mate + limonada de galão" faz parte da cultura carioca, onde as praias podem ser vistas como "lugares de invenção de modas e de divulgação de modos de vida alternativos”. (GONTIJO, 2002, p. 54)

Quem passou por alguma praia do Rio de Janeiro no verão provavelmente ouviu o grito: 'Ó o Mate! Ó o limão! Limonada, Mate!' ou alguma outra das muitas variações existentes. Por trás dos gritos estão homens de todas as idades, vestidos num uniforme laranja com dois galões nos ombros e um saco do famoso biscoito de polvilho Globo nas mãos. ${ }^{16}$ (MENDONÇA, 2018)

Mas os tradicionais ambulantes passaram por um período difícil no final de 2009, quando a prefeitura da cidade do Rio de Janeiro proibiu a venda de mate e de limonada em galões nas praias cariocas por questões relativas à higiene dos produtos. ${ }^{17}$ (MENDONÇA, 2012) Tal proibição causou comoção e alvoroço junto à população; e frequentadores das praias chegaram a fazer abaixo-assinado pela volta da tradição da cidade. ${ }^{18}$ (MENDONÇA, 2018) Após a repercussão negativa, o governo municipal voltou atrás, e

\footnotetext{
15 Ver: https://blogs.oglobo.globo.com/gente-boa/post/gourmetizacao-limao-do-mate-e-vendido-como -limonada-suica-na-praia-de-ipanema.html

16 Ver: https://www.bbc.com/portuguese/geral-42643527

17 Ver:http://g1.globo.com/rio-de-janeiro/noticia/2012/03/vendedores-de-mate-na-praia-agora-sao-patrimonio-do-rio-diz-paes.html

18 Ver: https://www.bbc.com/portuguese/geral-42643527
} 
liberou os vendedores ambulantes de mate e limonada de galão. E no dia 2 de março de 2012 (pouco mais de dois anos após a polêmica proibição), o então prefeito Eduardo Paes declarou os vendedores ambulantes de mate, limonada e de biscoito de polvilho das praias cariocas patrimônio cultural e imaterial da cidade do Rio de Janeiro via Decreto ${ }^{\circ} 35.179 / 2012$. (RIO DE JANEIRO , 2012) Degustadas sem bebida, acompanhadas de mate, de limonada ou de ambos (mate com limão), as rosquinhas de polvilho remetem ao imaginário da cidade.

\section{O "BIXCOITO" QUE É UM DOS SINÔNIMOS DA "CARIOQUICE": CORRELAÇÕES ENTRE O PRODUTO, A MARCA E O IMAGINÁRIO DA CIDADE}

Conforme exposto no tópico dois, as comemorações dos 400 anos do Rio de Janeiro foram marcadas por um cenário no qual o passado da cidade, seus marcos fundadores e mitos de origem estiveram na ordem do dia. (MESQUITA, 2014) Ou seja, o Rio vivia um momento de explosão criativa em 1965; e artistas e intelectuais se movimentaram no sentido de fixar a cidade como capital cultural do país. $\mathrm{Na}$ ocasião, o Golden Room ${ }^{19}$ do Copacabana Palace exibiu o espetáculo "Rio de 400 Janeiros", musical inspirado pelo quarto centenário de fundação da cidade. (PORTO, 2014) Todavia, o Rio foi deixando aos poucos de ser somente um produtor e exportador da brasilidade. A cidade passou a apresentar uma série de características próprias, "particulares, permitindo que falemos, então, de uma espécie de carioquidade”. (GONTIJO, 2002, p. 42)

Nesse contexto, vale destacar que um dos traços marcantes da "carioquice" ou "carioquidade" (GONTIJO, 2002) é o sotaque. Chamado de "carioquêx", o modo de falar do carioca força o chiado da letra "s", bem como "arranha da garganta" ao pronunciar o "r" - e também troca a letra "e" pela "i” - exemplo: no Rio, a palavra "esquerda"vira "ixquerrrrda". ${ }^{20}$ (BETIM, 2016) É interessante observar que o chiado presente no sotaque carioca (que faz com que a letra s tenha o som da letra x) surgiu em virtude da

19 'Golden Room' é o nome de um dos salões mais famosos do hotel Copacabana Palace. A origem do nome deve-se à cúpula dourada localizada na parte central do teto do salão.

20 Ver: https://brasil.elpais.com/brasil/2016/08/06/cultura/1470502556_718385.html 
população da cidade ter sido composta por quase um terço de portugueses. ${ }^{21}$ (PORTUGUESES..., 2013) Cabe ressaltar que, para fugir do Bloqueio Continental decretado por Napoleão Bonaparte, a Corte Portuguesa se transferiu para o Rio de Janeiro no ano de 1808. (ABREU, 2000) E até inícios do século $\mathrm{XX}$, “os imigrantes portugueses representavam o maior contingente de estrangeiros em duas cidades brasileiras: Rio de Janeiro e São Paulo”. (LESSER, 2015, p. 148)

Partindo da discussão acerca do sotaque carioca, a palavra "biscoito" em "carioquêx" 22 costuma ser pronunciada do seguinte modo: "bixcoito". E tanto o produto Biscoito Globo quanto a identidade visual da marca exibida em diversos bens de consumo, como: bolsas, cangas, camisetas etc.tornaram-se presença constante nas praias e em demais locais da cidade, fazendo parte da personalidade do Rio de Janeiro. Portadores de significado, “os bens de consumo definitivamente não são meras mensagens; eles constituem o próprio sistema. Tire-os da interação humana, e você desmantela tudo”. (DOUGLAS; ISHERWOOD, 2004, p. 120)

Apesar da simplicidade que caracteriza a gestão da Panificação Mandarinocujas práticas organizacionais não contemplam grandes investimentos em publicidade e ferramentas sofisticadas em sua comunicação de marketing-, o Biscoito Globo e demais itens com a sua respectiva marca remetem espontaneamente ao imaginário carioca, suscitando nas pessoas a alma do Rio de Janeiro, incluindo as suas praias. Para Legros e demais autores (2007), as imagens e visões ordenam as significações que nos reportam não ao racional (ou irracional), mas ao imaginário. Tecido conjuntivo entre as disciplinas, o imaginário é o reflexo que acrescenta significados ao banal significante. (DURAND, 1998) E em se tratando do imaginário carioca, o mesmo vai além da delimitação geográfica. Para Santos e Veloso (2009, p. 97):

[...] o imaginário carioca não se constrói pela geografia, e sim por outras características. [...] Já que o que remete à identificação e ao orgulho são as características de personalidade atribuídas ao povo e à cidade - o jeito despojado, a abertura, etc. - procede-se a uma

21 Ver em: http://www1.folha.uol.com.br/livrariadafolha/2013/06/1288985-portugueses-deixaram-sotaque-carioca-como-heranca-diz-livro.shtml

22 Carioquês (ou 'carioquêx') é a palavra popularmente utilizada para definir as gírias e o sotaque dos cariocas. 
personificação do espaço: o Rio de Janeiro não é aquele espaço físico assim demarcado nos mapas: é todo o espaço imaginado ao qual se atribuem aquelas características de personalidade; e o carioca não é quem vive naquela delimitação geográfica, mas sim todo aquele que, mesmo vivendo nos arredores daquele espaço físico, compartilha aquele imaginário.

E mesmo que as políticas e os projetos urbanos contemporâneos insistam em produzir uma imagem singular e única para as cidades (JACQUES, 2005), elas resistem. Lipovetsky e Roux (2005) apontam que a imagem corresponde ao conjunto das associações estocadas na memória do indivíduo. Rede complexa de atividades, a memória deve ser vista partindo da pluralidade de funções inter-relacionadas. (JEDLOWSKI, 2005)

É interessante observar também que, quando o assunto diz respeito aos elementos estrategicamente planejados para o fortalecimento da imagem da marca do Biscoito Globo, a Panificação Mandarino parece andar na contramão. A empresa não investe em campanhas publicitárias, recusou ofertas de abertura de franquias em outros estados do Brasil, jamais mudou a embalagem do produto e tem um único ponto central de distribuição desde 1965: a fábrica, situada na Rua do Senado, no centro do Rio de Janeiro. ${ }^{23}$ (BERNARDO, 2016)

O Biscoito Globo sempre foi comercializado em saquinhos de papel; e, mais recentemente, adotou também os saquinhos de plástico - para varejistas como padarias, bancas de jornais etc. Desde o ano de 1963 que a embalagem possui o desenho do bonequinho utilizado como personagem na seção de crítica de cinema do jornal $O$ Globo, chamada de "O bonequinho viu". ${ }^{24}$ (O JUBILEU..., 2003) Na época, foram inseridos desenhos de três torres para compor a estampa da embalagem do produto: Eiffel (França), Pisa (Itália) e a de Belém (Portugal). Porém, surgiu um problema referente aos desenhos utilizados na embalagem: era fundamental que o Rio de Janeiro também estivesse representado, e não existe uma torre na cidade. (MANIER, 2017) Sendo assim, a solução encontrada foi inserir o desenho do Pão de Açúcar na embalagem do produto. Exuberante como relevo, o Pão de Açúcar “tornou-se um ponto de referência fundamental para a

\footnotetext{
23 Ver: http://super.abril.com.br/saude/biscoito-de-polvilho-conheca-mais-sobre-o-petisco-mais-praiano-do-brasil/

24 Ver: http://www.varejista.com.br/cases/1080/biscoitos-globo. Acesso em: 1 jul. 2019.
} 
identificação da cidade, por estar localizado na ponta mais extrema, do lado esquerdo da entrada da Baía de Guanabara”. (PERROTTA, 2015, p. 172)

Manier (2017, p. 107) cita que os criadores do Biscoito Globo desenvolveram uma embalagem que é "um mal feito que é bem feito e que dá certo", e que soa como espontânea e intuitiva, pois é uma embalagem desenvolvida por quem não é profissional. Tais elementos também reforçam a ausência de preocupações em relação à adoção de estratégias e táticas de marketing na concepção de embalagens quando se trata da famosa rosquinha de polvilho. Sejam as de papel ou as de plástico, as embalagens do Biscoito Globo são encontradas apenas em duas cores: verde (para o sabor salgado) e vermelha (para o sabor doce). A escolha pelas cores diferentes serviu para facilitar os ambulantes na hora de distinguir o biscoito doce do salgado, já que muitos eram analfabetos quando o produto chegou ao Rio de Janeiro em 1965. (BERNARDO, 2016) Entretanto, ambas as cores e sabores permanecem até os dias atuais.

Vale destacar que a empresa que produz o Biscoito Globo também comercializa cangas com a marca do produto nas cores verde e vermelho em suas páginas nas redes sociais Facebook ${ }^{25}$ e Instagram. ${ }^{26}$ Em paralelo a isso, é comum ver os mais diversos objetos exibindo a marca do Biscoito Globo sendo vendidos por terceiros pela cidade do Rio de Janeiro, conforme ressalta Manier (2017, p. 101-102):

São cangas, bolsas, camisetas, chinelos, canecas, bonés, capachos, capas de celular, barracas, cadeiras de praia... estampados com a embalagem dos biscoitos sem que nenhuma confecção, loja ou artesão pague um centavo por isso. Em outras palavras, não há exploração da marca por parte da empresa e nem política de licenciamento. É como se o nome Biscoito Globo fosse de domínio público. E a justificativa também é simples: não há tempo e nem pessoal para agenciar a marca.

\footnotetext{
25 Ver: https://www.facebook.com/biscoitogloborj/photos/a.1599778956979408/223387214357008-3 /?type=3\& comment_id=2272028153087815\&notif_id=1570459140443858\&notif_t=feedback_reaction_generic 
O culto ao corpo bronzeado e à praia, a corporeidade e a preocupação com a saúde física e mental, as invenções de modos de vida alternativos, a criatividade musical, o ciclo festivo do verão, o amor pelo futebol e pelas festas esportivas, o sotaque e as gírias, o apego à cidade, a urbanidade, a violência emotiva e tantos outros elementos escolhidos aleatoriamente compõem o repertório cultural do carioca. (GONTIJO, 2002) E embora tenha nascido em São Paulo, o Biscoito Globo compõe a identidade e o estilo de vida carioca. Para Bueno (2008), os estilos de vida tornaram-se uma das primeiras instâncias de construção de identidades na contemporaneidade, aflorando e ganhando visibilidade no interior de um amálgama de práticas culturais. $\mathrm{O}$ estilo de vida do carioca pode ser percebido através de gestos rotineiros como a maneira de vestir e de comer, embora as rotinas estejam reflexivamente abertas às mudanças à luz da natureza móvel da autoidentidade. (GIDDENS, 2002)

Ou seja, o futebol dominical no Maracanã, as rodas de samba regadas a feijoada e caipirinha, as idas à praia para o mergulho no mar são alguns dos mecanismos identitários da cidade do Rio de Janeiro. E no que diz respeito aos hábitos alimentares - seja no cotidiano ou nos momentos de lazer -, até o jeito de comer dos cariocas é tipicamente seu. (SANTOS; VELOSO, 2009) Em matéria publicada pela BBC News Brasil, Fabiano (que vende biscoito, mate e limonada na praia) declarou: "O mate e o Biscoito Globo são como o Cristo Redentor no Rio de Janeiro. Se não beber mate e comer Biscoito Globo, é como ir na Disney e não ver o Mickey”. (MENDONÇA, 2018) Sendo assim, o mate e a limonada acompanhados do "bixxxcoito" Globo fazem parte do cardápio do carioca quando se trata de "belixxxcar" na praia.

No ano de 2016, a polêmica se instaurou no Rio de Janeiro quando um repórter americano do The New York Times criticou o sabor do Biscoito Globo. Afinal de contas, "mexer com o Biscoito Globo é mexer com o imaginário de uma cidade”, e o imaginário tem algo de imponderável, pois é o estado de espírito que caracteriza um povo. (MAFFESOLI, 2001)

\section{“O BISCOITO GLOBO É SEM GOSTO!": A AVALIAÇÃO QUE IRRITOU OS CARIOCAS}

O Rio de Janeiro sediou os Jogos Olímpicos no ano de 2016, que aconteceu entre os dias 5 e 21 de agosto. A cidade recebeu 11.238 atletas, e o 
megaevento teve a participação de 207 países. $^{27}$ (JOGOS..., 2016) Também chamado de "Rio 2016", os Jogos Olímpicos foram percebidos como uma oportunidade que aceleraria a transformação do Rio de Janeiro em uma cidade global ainda maior. (JOGOS..., 2016) Partindo de tal raciocínio, pode-se observar que existe um esforço no sentido de consolidar o Rio de Janeiro como uma cidade globalizada, cujo projeto e respectivas ideias muitas vezes tendem a asfixiar as dinâmicas culturais presentes na mesma. (FERNANDES; HERSCHMANN, 2018)

Durante a realização dos Jogos Olímpicos 2016, os locais de competição foram agrupados em quatro bairros da cidade do Rio de Janeiro: Barra da Tijuca, Copacabana, Deodoro e Maracanã. A cerimônia de abertura dos Jogos Olímpicos foi realizada no Maracanã no dia 5 de agosto de 2016; e em meio às vaias ecoadas para o então presidente interino Michel Temer, a maioria dos veículos estrangeiros que acompanhou a cerimônia a elogiou. ${ }^{28}$ (ABERTURA..., 2016) No dia 13 de agosto - oito dias após a abertura oficial dos Jogos Olímpicos 2016 -, o jornal americano The New York Times publicou uma matéria sobre a gastronomia da cidade intitulada: "Sem gosto, Biscoito Globo é o símbolo perfeito da gastronomia no Rio de Janeiro”. (SEGAL..., 2016) Produzida pelo jornalista americano David Segal após visitar a fábrica do Biscoito Globo e provar a rosquinha durante a realização da Rio 2016, a reportagem ${ }^{29}$ cita que o petisco: “é um alimento sem gosto, símbolo perfeito do Rio - uma cidade em que o cenário de restaurantes é meh". ${ }^{30} \mathrm{O}$ texto descreve o Biscoito Globo do seguinte modo: "ar transformado em bolacha, em forma de anel. Coloque um na sua boca e será como se seus dentes estivessem em uma festa para a qual sua língua não foi convidada”. ${ }^{31}$ (THE NEW..., 2016) De acordo com o repórter, a rosquinha

27 Ver: https://www.olympic.org/rio-2016

28 Ver: https://www1.folha.uol.com.br/esporte/olimpiada-no-rio/2016/08/1799704-abertura-dario-2016 -e-elogiada-pela-imprensa-internacional-veja-repercussao.shtml

29 Ver: http://g1.globo.com/rio-de-janeiro/olimpiadas/rio2016/blog/brasil-visto-de-fora-na-olimpiada/post/new-york-times-faz-materia-sobre-biscoitos-globo-sem-gosto-assim-como-culinaria-carioca.html

30 "Meh" (pronuncia-se 'mé’) é uma expressão sintetizada pela The New York Times Magazine. É utilizada para classificar um assunto/uma pauta que não é 'nem quente nem não quente' (no original em inglês, 'not hot, notnot'). Ou seja: algo que é 'morno', quase indiferente.

31 Ver em: http://g1.globo.com/rio-de-janeiro/olimpiadas/rio2016/blog/brasil-visto-de-fora-na-olimpiada/post/new-york-times-faz-materia-sobre-biscoitos-globo-sem-gosto-assim-como-culinaria-carioca.html 
não é saborosa: "O Biscoito Globo faz, portanto, parte da grande tradição culinária de comestíveis regionais que deixa os forasteiros perplexos. Mas essa distinta ausência de sabor também o torna um símbolo perfeito da comida no Rio”. (SEGAL..., 2016)

$\mathrm{Na}$ realidade, a reportagem de David Segal não faz apenas uma análise (seguida de posterior crítica) ao Biscoito Globo - mas sim um ataque à gastronomia da cidade, conforme publicou a Veja Rio:

As alfinetadas vão além do biscoito e chegam à culinária da cidade, em geral. Apesar de dizer que existem excelentes lojas de suco, carrinhos de churros e alguns restaurantes, além de churrascarias onde se pode comer à vontade, ele enfatiza que as casas de self-service são bufês de 'variedade deprimente', que misturam comidas como macarrão e sushi com salsicha e raramente feitos com ingredientes frescos. Para completar, a crítica diz que a gastronomia carioca é um 'segredo infeliz' da capital fluminense. (THE NEW..., 2016)

Vocábulo composto por gasteur (ventre, estômago) nomo (lei) e pelo sufixo-ia, gastronomia significa, etimologicamente, estudo ou observância das leis do estômago. (FRANCO, 2001) Nesse sentido, a receita dobiscoito Globo é simples, composta por apenas quatro ingredientes: polvilho, gordura, leite e ovos. Tais ingredientes permanecem os mesmos desde o início da produção da rosquinha na cidade de São Paulo durante a década de 1950. Visando facilitar o crescimento da massa, a receita costuma ganhar apenas um pouco mais de gordura, leite, sal ou açúcar. (MANIER, 2017)

E apesar das críticas do jornalista americano, o biscoito Globo foi considerado "uma das sete maravilhas da gastronomia fluminense" de acordo com concurso promovido pelo jornal O Globo. (AS SETE..., 2013) Realizado entre agosto e outubro do ano de 2013, o concurso aconteceu pela internet e computou cerca de 20 mil votos em sete categorias gastronômicas, dentre as quais "Entradas \& Petiscos" - quesito no qual o biscoito Globo venceu. ${ }^{32}$ (ARAÚJO, 2013) E junto com os demais vencedores do concurso (como a caipirinha na categoria "Bebidas"), a rosquinha de polvilho foi considerada

32 Ver: https://oglobo.globo.com/rio/caipirinha-angu-estao-entre-as-7-maravilhas-da-gastronomia-fluminense-10960490 
uma das "delícias que colaboram para o desenvolvimento socioeconômico, cultural e turístico e que têm a marca registrada da culinária do Estado do Rio, da capital e do interior”. (ARAÚJO, 2013)

Ao atacar o biscoito Globo e declarar que "o paladar é um sentido que o Rio ainda não desenvolveu plenamente”, (SEGAL, 2016) o jornalista David Segal irritou profundamente os cariocas, que se sentiram ofendidos com as declarações feitas na reportagem do The New York Times. Para ilustrar o mal-estar gerado pelos comentários do jornalista, vale observar a resposta do vendedor ambulante Roberto Gomes - que comercializa o biscoito na praia de Copacabana -, em reportagem intitulada "Cariocas reagem à crítica do New York Times sobre biscoito Globo": "São pessoas que não conhecem a tradição do biscoito. Ele é muito querido nas praias e muito aceito, tanto pela classe alta quanto pela classe baixa, pessoa rica, pobre, criança, adulto". ${ }^{33}$ (SOUZA, 2016)

Mas o imbróglio não parou por aí. A empresa fabricante do biscoito Globo se defendeu nas redes sociais, e publicou um banner com a seguinte mensagem: “Obrigado, New York Times! Uma crítica negativa nunca repercutiu tão positivamente para uma marca" ${ }^{34}$ Sendo assim, a crítica à rosquinha de polvilho acabou gerando um efeito do tipo "mexeu com o biscoito Globo, mexeu com todos os cariocas". Tal fato inclusive fez com que a resposta da empresa nas redes sociais contemplasse a seguinte hashtag: ${ }^{35}$ \#somostodosbiscoitoglobo. ${ }^{36}$

Nesse contexto, vale destacar que existem determinados alimentos e modos de comer que são tidos como tipicamente cariocas pelo fato de que são percebidos como portadores das qualidades intrínsecas ao carioca. (SANTOS; VELOSO, 2009) E existe uma ligação da gastronomia com a identidade regional, já que a comida tem o papel de destacar identidades e, conforme o contexto, elas podem ser nacionais, regionais, locais, familiares

33 Ver: http://g1.globo.com/rio-de-janeiro/olimpiadas/rio2016/noticia/2016/08/cariocas-reagem-critica-do-new-york-times-sobre-biscoito-globo.html

34 Ver: https://www.facebook.com/biscoitogloborj/photos/pb.1599771140313523.-2207520000.14713691 50./1629742760649694/?type=3\&theater

35 Uma hashtag é qualquer palavra ou frase precedida pelo símbolo cerquilha (\#) muito utilizada entre os usuários das redes sociais. A cerquilha transforma qualquer expressão em um link indexador que faz com que seja mais fácil encontrar e seguir uma conversa sobre o assunto contido nela.

36 Ver: https://www.facebook.com/biscoitogloborj/photos/pb.1599771140313523.-2207520000.14713691 50./1629742760649694/?type=3\&theater 
ou pessoais. (DA MATTA, 1987) E ao criticar o biscoito Globo, o jornalista do The New York Times irritou os cariocas porque estes se sentiram "ofendidos" em um dos elementos ligados à sua identidade: a alimentação. E após as críticas feitas à rosquinha de polvilho na reportagem do jornalista americano David Segal, as pessoas foram em defesa do mesmo nas redes sociais. No Twitter, foram observados comentários como: "Biscoito Globo não é uma comida. É um conceito'. / 'Falar mal do Biscoito Globo é como dizer que Gisele Bundchen é baranga. Ofendeu uma instituição nacional'. / 'Não entendo como uma nação que acha graça em manteiga de amendoim possa ousar falar mal do Biscoito Globo". ${ }^{37}$

Na ocasião, a mídia em geral também publicou notícias sobre a indignação causada pelas críticas que a rosquinha recebeu no The New York Times, onde uma delas ressaltou comparações entre o "Biscoito Globo e o tão amado bolo feito pela vovó" (em uma referência às receitas culinárias de família); e também relatou de modo jocoso que a reportagem de David Segal geraria uma grave "crise diplomática" entre o Brasil e os Estados Unidos em decorrência dos comentários negativos sobre o Biscoito Globo. ${ }^{38}$ (BAZZO, 2016)

As críticas chegaram ao "pai" da rosquinha de polvilho, Milton Ponce. Falecido em maio de 2017 em decorrência de um câncer, Milton recebeu o jornalista David Segal em agosto de 2016 - durante a realização dos Jogos Olímpicos - na fábrica localizada na Rua do Senado para a realização da entrevista, como se observa a seguir:

Apesar de reservado e cauteloso para falar de si e da empresa, ainda mais para abrir as portas da produção a jornalistas, Milton Ponce e equipe receberam educadamente os visitantes e responderam a suas perguntas, mesmo percebendo que algumas informações poderiam acabar saindo erradas por causa da falta de domínio do português da intérprete. Em sequência, receberam ainda a visita de um fotógrafo contratado pelo jornal para clicar fotos ilustrativas. E aguardou-se a reportagem. (MANIER, 2017, p. 152)

\footnotetext{
37 Comentários extraídos pela autora em agosto de 2016 da rede social Twitter, após a publicação da reportagem do jornalista David Segal no The New York Times.

38 ver: http://www.huffpostbrasil.com/2016/08/14/biscoito-globo-new-york-t_n_11510404.html
} 
Logo após a repercussão da reportagem, o filho de Milton Ponce comentou que falar mal do sabor do biscoito “é uma questão de gosto”. Nesse contexto, é importante entender que, apesar de apresentar uma perspectiva químico-fisiológica, o gosto humano inclui a noção da alma como fator decisivo de julgamento pessoal das impressões transmitidas pelos órgãos. (BRILLAT-SAVARIN, 1995) E em se tratando do imaginário carioca, o Biscoito Globo “não é insosso e sem gosto”, já que faz parte das percepções que o indivíduo tem de si e de sua relação com o Rio de Janeiro. (SANTOS; VELOSO, 2009)

Na ocasião, Marcelo Ponce (filho de Milton) declarou ao jornal O Globo como seu pai recebeu a reportagem do The New York Times:

\begin{abstract}
Meu pai está com 80 anos. Recebeu o jornalista aqui na fábrica e está chateado. Não por terem falado mal do biscoito. Disseram que é insosso, sem sal e sem gosto, e isso é uma questão de gosto. Ele está chateado porque falaram mal da culinária carioca como um todo. Mas ele, por outro lado, está muito feliz com a repercussão positiva na internet, nas redes sociais, com todos nos defendendo. (SOUZA, 2016)
\end{abstract}

Nos dias seguintes à publicação da matéria no jornal americano, o telefone da Panificação Mandarino tocou sem parar; e em meio às mensagens que transmitiam "tanto apoio quanto indignação, vários jornalistas de diferentes mídias telefonaram querendo filmar a fábrica, fazer entrevistas e escrever matérias com um teor de resposta”. (MANIER, 2017, p. 153) Um advogado chegou a oferecer os serviços jurídicos à Panificação Mandarino, alegando a legitimidade de um processo contra o jornal americano partindo da repercussão da reportagem do The New York Times. (MANIER, 2017)

Definido como "insosso e sem gosto", o biscoito Globo contou com uma "defesa apaixonada" das pessoas -incluindo alguns cariocas famosos-, que inundaram as redes sociais com duas variedades de posts sobre a reportagem do The New York Times: ataques rancorosos ao jornal americano e defesas do petisco. ${ }^{39}$ (URBIM, 2016) Pode-se citar como exemplo a atitude do arquiteto carioca Chicô Gouvêa, que na época trocou as suas fotos de perfil nas redes sociais por uma imagem do biscoito Globo. (URBIM, 2016) 
Em julho de 2019, outra polêmica envolveu a rosquinha, quando o chef de cozinha francês Claude Troisgros lançou a sua linha de biscoitos de polvilho. Oferecido nos sabores ervas de provence, hot curry, chocolate, queijo pecorino romano e original com sal marinho, o biscoito surge como uma possibilidade de "gourmetização" do tradicional polvilho carioca, que possui apenas os sabores doce e salgado. ${ }^{40}$ (ROCHADEL, 2019) E antes mesmo de ser vendido nas areias das praias do Rio de Janeiro, o produto criado por Troisgros gerou repercussão. Nesse contexto, é interessante observar a opinião da carioca Yula Correia na reportagem intitulada "Novo biscoito de polvilho ‘gourmetizado' gera polêmica nas praias do Rio”, publicada pelo jornal O Dia: "Sol, mate e biscoito Globo, essa é a combinação perfeita que o Rio oferece. Não tem porque modificar uma receita de sucesso. Mas entendo que estamos em um momento onde todos querem reinventar as coisas. Ele tá mexendo em casa de marimbondo". ${ }^{41}$ (SCHUINDT; DANDARA, 2019)

Tripudiada pelo jornalista americano David Segal em 2016 e "gourmetizada” pelo chef Claude Troisgros, a rosquinha de polvilho - que quase foi "batizada" de Copacabana -completou 64 anos em 2019. E permanece como o "bixxxxcoito" que habita o imaginário e o coração dos cariocas.

\section{CONSIDERAÇÕES FINAIS}

O que parece evidenciar-se a partir dos relatos e fatos pesquisados e apresentados neste artigo é que as construções identitárias de uma cidade, e de suas marcas, são atravessadas tanto por elementos culturais globais como locais. No caso do biscoito Globo, compreendemos que a força da localidade - os modos de comer, os hábitos cotidianos do consumo do produto e toda a ambiência onde se compartilha o gosto por tomá-lo com mate, sentado na praia, na calçada - tece um imaginário tão potente na cidade que a maioria dos cariocas não abre mão de nomear essa marca como "sua marca”. Há uma potência identitária, e uma cumplicidade entre aqueles que vivem e praticam a cidade a partir dos modos de consumir esse alimento. A

\footnotetext{
40 Ver: https://www.metropoles.com/gastronomia/comer/globo-gourmet-claude-troisgros-lanca-linha-de-biscoito-de-polvilho

41 Ver: https://odia.ig.com.br/rio-de-janeiro/2019/07/5665660-novo-biscoito-de-polvilho--gourmetizado --gera-polemica-nas-praias-do-rio.html\#foto=1
} 
afirmação "Biscoito, mate, água... ó ó biscoito! É a cara do Rio. Biscoitinho de polvilho!"nos auxilia a compreender que nem sempre os produtos culturais globais conseguem se impor ao gosto e práticas culturais locais. A força do imaginário, ou seja, das imagens, das memórias e sensibilidades cariocas, resistem em um pacote de polvilho.

\section{REFERÊNCIAS}

60 ANOS do Congresso Eucarístico do Rio. Arquidiocese de São Sebastião do Rio de Janeiro, Rio de Janeiro, 2015. Disponível em: http://arqrio.org/formacao/ detalhes/816/60-anos-do-congresso-eucaristico-do-rio.\%20Acesso\%20em:\%20 24\%20maio\%202019. Acesso em: 27 jul. 2020.

ABERTURA da Rio-2016 é elogiada pela imprensa internacional: veja repercussão. Folha de São Paulo, São Paulo, 2016. Disponível em: https://wwwl.folha.uol.com.br/ esporte/olimpiada-no-rio/2016/08/1799704-abertura-da-rio-2016-e-elogiada-pelaimprensa-internacional-veja-repercussao.shtml. Acesso em: 27 jul. 2020.

ABREU, R. M. R. M. A capital contaminada: a construção da identidade nacional pela negação do espírito carioca. In: LOPES, A. H. (org.). Entre a Europa e a África:a invenção do carioca. Rio de Janeiro: Fundação Casa de Rui Barbosa: Topbooks, 2000. p. 167-185.

ARAÚJO, C. Vendedores de mate e biscoito de polvilho. Portal MultiRio, Rio de Janeiro, 2014. Disponível em: http://www.multirio.rj.gov.br/index.php/leia/ reportagens-artigos/reportagens/913-patrimonio-imaterial-carioca-vendedores-demate-e-biscoito-de-polvilho. Acesso em: 27 jul. 2020.

ARAÚJO, P. R. Caipirinha e angu estão entre as sete maravilhas da gastronomia fluminense. O Globo, Rio de Janeiro, 2013. Disponível em: https://oglobo. globo.com/rio/caipirinha-angu-estao-entre-as-7-maravilhas-da-gastronomiafluminense-10960490. Acesso em: 28 jul. 2020.

AS SETE maravilhas da gastronomia fluminense. O Globo, Rio de Janeiro, 2013. Disponível em: https://infograficos.oglobo.globo.com/rio/as-sete-maravilhas-dagastronomia-fluminense/biscoito-globo-8506.html\#description_text. Acesso em: 27 jul. 2020.

BAZZO, G. Aqui não, queridinho! New York Times passa dos limites e critica Biscoito Globo. Huff Post, São Paulo, 2016. Disponível em: https://www. huffpostbrasil.com/2016/08/14/aqui-nao-queridinho-new-york-times-passa-doslimites-e-critica_n_11510404.html. Acesso em: 28 jul. 2020.

BERNARDO, A. Biscoito de polvilho: conheça mais sobre o petisco mais praiano do Brasil. Revista Super Interessante, Editora Abril, São Paulo, 2016. Disponível em: https://super.abril.com.br/saude/biscoito-de-polvilho-conheca-mais-sobre-o-petiscomais-praiano-do-brasil/. Acesso em: 27 jul. 2020. 
BETIM, F. Guia básico para entender e falar o "carioquêx" no Rio durante os Jogos Olímpicos. El País, São Paulo, 2016. Disponível em: Disponível em: https://brasil. elpais.com/brasil/2016/08/06/cultura/1470502556_718385.html. Acesso em: 27 jul. 2020.

BISCOITO Globo. Globo, Rio de Janeiro, 2019. Disponível em: https://www. biscoitoglobo.com.br/. Acesso em: 27 jul. 2020.

BRILLAT-SAVARIN, J. A fisiologia do gosto. São Paulo: Companhia das Letras, 1995. BUENO, M. L. Cultura e estilos de vida. In: BUENO, M. L.; CAMARGO, L. O. L. (org.). Cultura e consumo: estilos de vida na contemporaneidade. São Paulo: SENAC São Paulo, 2008. p. 9-15.

CAPUCCI, R. Ser carioca vai além de nascer no Rio de Janeiro, é um estado de espírito. G1, Rio de Janeiro, 28 fev. 2015.

CASARIN, R. Você sabia que o Biscoito Globo, ícone do Rio de Janeiro, nasceu em São Paulo? É o que mostra biografia do quitute. Portal UOL, São Paulo, 2017. Disponível em: https://paginacinco.blogosfera.uol.com.br/2017/01/18/voce-sabiaque-o-biscoito-globo-icone-do-rio-de-janeiro-nasceu-em-sao-paulo-e-o-que-mostrabiografia-do-quitute/. Acesso em: 27 jul. 2020.

CORREAA, S. B. Lazer, trabalho e sociabilidade na Praia de Copacabana. In: BARBOSA, L.; PORTILHO, F.; VELOSO, L. et al. (org.). Consumo: cosmologias e sociabilidades. Rio de Janeiro: Mauad X, 2009. p. 135-156.

DA MATTA, R. Sobre o simbolismo da comida no Brasil. Correio da Unesco, [Rio de Janeiro], v. 15, n. 7, p. 21-23, 1987.

DO ESTADO da Guanabara ao estado do Rio de Janeiro: a fusão. Portal MultiRio, Rio de Janeiro, 2015. Disponível em: http://multirio.rio.rj.gov.br/index.php/estude/ historia-do-brasil/rio-de-janeiro/71-um-rio-de-muitos-janeiros/3365-a-fusao-doestado-da-guanabara-ao-estado-do-rio-de-janeiro. Acesso em: 27 jul. 2020.

DOUGLAS, M.; ISHERWOOD, B. O mundo dos bens: para uma antropologia do consumo. Rio de Janeiro: Ed. UFRJ, 2004.

DURAND, G. Campos do imaginário. Lisboa: Instituto Piaget, 1998.

EM 1955, 36 ${ }^{\circ}$ Congresso Eucarístico fez do Rio a capital mundial do catolicismo. O Globo, Rio de Janeiro, 2016. Disponível em: https://acervo.oglobo.globo.com/ em-destaque/em-1955-36-congresso-eucaristico-fez-do-rio-capital-mundial-docatolicismo-9123322. Acesso em: 27 jul. 2020.

FERNANDES, C. S.; HERSCHMANN, M. Entre as "conchas vazias" e a potencialidade das dinâmicas criativas urbanas cotidianas na área do porto do Rio de Janeiro. In: FERNANDES, C. S.; HERSCHMANN, M. Cidades musicais: comunicação, territorialidade e política. Porto Alegre: Sulina, 2018. p. 19-56. 
FRANCO, A. De caçador a gourmet: uma história da gastronomia. São Paulo: SENAC, 2001.

FREITAS, R. F.; LINS, F.; SANTOS, M. H. C. Megaevento: uma lógica de transformação social. In: FREITAS, R. F.; LINS, F.; SANTOS, M. H. C. (org.). Megaeventos, comunicação e cidade. Curitiba: CRV, 2016. p. 21-38.

GIDDENS, A. Modernidade e identidade. Rio de Janeiro: Zahar, 2002.

GONTIJO, F. S. Carioquice ou Carioquidade?: ensaio etnográfico das imagens identitárias cariocas. In: GOLDENBERG, M. (org.). Nu \& Vestido: dez antropólogos revelam a cultura do corpo carioca. Rio de Janeiro: Record, 2002. p. 41-77.

GRUPAMENTO Especial de Praia e Marítimo. Portal da Prefeitura do Rio de Janeiro, Rio de Janeiro, 2010. Disponível em: http://www.rio.rj.gov.br/web/gmrio/especialde-praia. Acesso em: 27 jul. 2020.

GUIMARÃES, C. Gourmetização: limão do mate é vendido como "limonada suíça" na Praia de Ipanema. O Globo, Rio de Janeiro, 2015. Disponível em: https://blogs. oglobo.globo.com/gente-boa/post/gourmetizacao-limao-do-mate-e-vendido-comolimonada-suica-na-praia-de-ipanema.html. Acesso em: 27 jul. 2020.

JACQUES, P. B. Patrimonialização e estetização urbanas. Prefácio. In: JEUDY, H. P. Espelho das cidades. Rio de Janeiro: Casa da Palavra, 2005. p. 9-12.

JEDLOWSKI, P. Memória e a mídia: uma perspectiva sociológica. In: SÁ, C. P. (org.). Imaginário e representações sociais. Rio de Janeiro: Museu da República, 2005. p. 87-98.

JOGOS Olímpicos 2016. Jogos Olímpicos 2016, Rio de Janeiro, 2016. Disponível em: https://www.olympic.org/rio-2016. Acesso em: 27 jul. 2020.

LEGROS, P.; MONNEYRON, F.; RENARD, J. B. et al. Sociologia do imaginário. Porto Alegre: Sulina, 2007.

LESSER, J. A invenção da brasilidade: identidade nacional, etnicidade e políticas de imigração. São Paulo: UNESP, 2015.

LIPOVETSKY, G.; ROUX, E. O luxo eterno: da idade do sagrado ao tempo das marcas. São Paulo: Companhia das Letras, 2005.

MAFFESOLI, M. A conquista do presente. Natal: Argos, 2001.

MANIER, A. B. Ó, o Globo: a história de um biscoito. Rio de Janeiro: Valentina, 2017.

MENDONÇA, A. V. Vendedores de mate na praia agora são patrimônio do Rio, diz Paes. Portal de notícias. O Globo, Rio de Janeiro, 2012. Disponível em: http:// g1.globo.com/rio-de-janeiro/noticia/2012/03/vendedores-de-mate-na-praia-agorasao-patrimonio-do-rio-diz-paes.html. Acesso em: 27 jul. 2020. 
MENDONÇA, R. A rotina dos vendedores de mate nas praias do Rio, sob calor de $40^{\circ}$ e com 50kg nas costas. BBC Brasil, Rio de Janeiro, 2018. Disponível em: https://www.bbc.com/portuguese/geral-42643527. Acesso em: 27 jul. 2020.

MESQUITA, C. A Guanabara comemora os 400 anos da cidade do Rio de Janeiro. In: TURAZZI, M. I.; LEITE, J. S.; MESQUITA, C. (org.). Rio 400+50: comemorações e percursos de uma cidade. Rio de Janeiro: Edições de Janeiro, 2014. p. 76-121.

MORRE Milton Ponce, um dos donos do Biscoito Globo, aos 78 anos. Extra, Rio de Janeiro, 18 maio 2017. Disponível em: https://extra.globo.com/noticias/rio/morremilton-ponce-um-dos-donos-do-biscoito-globo-aos-78-anos-21358206.html. Acesso em: 27 jul. 2020.

O JUBILEU do polvilho. Época, São Paulo, 2003. Disponível em: http://revistaepoca. globo.com/Revista/Epoca/0,,EDR54654-6012,00.html. Acesso em: 27 jul. 2020.

PALMIERI JUNIOR, V. Gourmetização em uma sociedade desigual: notas sobre a diferenciação de consumo de alimentos no Brasil. 2017. Tese (Doutorado em Desenvolvimento Econômico) - Universidade Estadual de Campinas, Campinas, 2017. Disponível em: http://repositorio.unicamp.br/bitstream/ REPOSIP/325569/1/PalmieriJunior_Valter_D.pdf. Acesso em: 24 maio 2019.

PERROTTA, I. Promenades do Rio: a turistificação da cidade pelos guias de viagem de 1873 a 1939. Rio de Janeiro: Rio450: Hybris Design, 2015.

PORTO, A. F. Copacabana Palace: imaginário, consumo e estilos de vida no palácio da Princesinha do Mar. 2014. Dissertação (Mestrado em Comunicação) - Programa de Pós Graduação em Comunicação, Universidade do Estado do Rio de Janeiro, Rio de Janeiro, 2014.

PORTUGUESES deixaram sotaque como herança. Folha de São Paulo,

São Paulo, 2013. Disponível em: https://wwwl.folha.uol.com.br/ livrariadafolha/2013/06/1288985-portugueses-deixaram-sotaque-carioca-comoheranca-diz-livro.shtml\#: :text=Por\%20quase\%20dois\%20s\%C3\%A9culos\%2C\%20 o,real\%20e\%20a\%20corte\%20portuguesa.\&text=No\%20cap\%C3\%ADtulo\%20 \%22Hist\%C3\%B3ria\%20da\%20L\%C3\%ADngua,sotaques\%20e\%20regionalismos\%20 dos\%20brasileiros. Acesso em: 27 jul. 2020.

PRIORE, M. D. Histórias da gente brasileira. São Paulo: LeYa, 2016.

RIO DE JANEIRO. Decreto ${ }^{\circ}$ 35.179, de 2 de março de 2012. Declara Patrimônio Cultural Carioca a atividade de vendedor ambulante de mate, limonada e biscoito de polvilho nas praias cariocas. Diário Oficial do Estado, Rio de Janeiro, 3 mar. 2012. Disponível em: http://www.rio.rj.gov.br/dlstatic/10112/4368015/4108330/ 18DECRETO35179AtividadedeVendedorAmbulantedeMateLimonadaeBiscoito dePolvilho.pdf. Acesso em: 27 jul. 2020. 
ROCHADEL, A. Globo gourmet? Claude Troisgros lança linha de biscoito de polvilho. Metrópoles, Brasília, DF, 2019. Disponível em: https://www.metropoles. com/gastronomia/comer/globo-gourmet-claude-troisgros-lanca-linha-de-biscoito-depolvilho. Acesso em: 28 jul. 2020.

SANTOS, E. I.; VELOSO, L. Consumo e sociabilidade na construção do imaginário carioca. In: BARBOSA, L.; PORTILHO, F.; VELOSO, L. et al. (org.). Consumo:cosmologias e sociabilidades. Rio de Janeiro: Mauad X, 2009. p. 87-118.

SCHUINDT, R.; DANDARA, L. Novo biscoito de polvilho "gourmetizado" gera polêmica nas praias do Rio. O Dia, Rio de Janeiro, 2019. Disponível em: https:// odia.ig.com.br/rio-de-janeiro/2019/07/5665660-novo-biscoito-de-polvilho-gourmetizado--gera-polemica-nas-praias-do-rio.html\#foto=1. Acesso em: 28 jul. 2020 .

SEGAL, D. Sem gosto, Biscoito Globo é o símbolo perfeito da comida do Rio de Janeiro. Portal UOL, São Paulo, 2016. Disponível em: https://noticias.bol.uol.com.br/ ultimas-noticias/internacional/2016/08/15/sem-sabor-biscoito-globo-o-torna-umsimbolo-perfeito-da-comida-do-rio-de-janeiro.htm. Acesso em: 27 jul. 2020.

SILVA, M. M. L. Crimes da era digital. Net, Rio de Janeiro, 1998. Disponível em: http://www.brazilnet.com.br/contexts/brasilrevista.htm. Acesso em: 28 nov. 1998.

SOUZA, E. Cariocas reagem à crítica do New York Times sobre biscoito Globo. O Globo, Rio de Janeiro, 2016. Disponível em: http://gl.globo.com/rio-de-janeiro/ olimpiadas/rio2016/noticia/2016/08/cariocas-reagem-critica-do-new-york-timessobre-biscoito-globo.html. Acesso em: 28 jul. 2020.

THE NEW York Times critica Biscoito Globo: "Sem gosto, assim como a culinária carioca”. O Globo, Rio de Janeiro, 2016. Disponível em: http://g1.globo.com/rio-dejaneiro/olimpiadas/rio2016/blog/brasil-visto-de-fora-na-olimpiada/post/new-yorktimes-faz-materia-sobre-biscoitos-globo-sem-gosto-assim-como-culinaria-carioca. html. Acesso em: 27 jul. 2020.

TRÂNSITO e estacionamento de veículos durante a realização do Congresso Eucarístico. Correio da Manhã, Rio de Janeiro, 1955. Disponível em: http://memoria.bn.br/ DocReader/Hotpage/HotpageBN.aspx?bib=089842_06\&pagfis=50201\&url=http:/ / memoria.bn.br/docreader\#. Acesso em: 27 jul. 2020.

TURAZZI, M. I. O aniversário da cidade: histórias e memórias que se cruzam. In: TURAZZI, M. I.; LEITE, J. S.; MESQUITA, C. (org.). Rio 400+50: comemorações e percursos de uma cidade. Rio de Janeiro: Edições de Janeiro, 2014. p. 18-73.

UM RIO de histórias: fusão da Guanabara. Portal MultiRio, Rio de Janeiro, 2015. Disponível em: http://www.multirio.rj.gov.br/index.php/assista/tv/8089fus\%C3\%A3o-da-guanabara. Acesso em: 27 jul. 2020.

URBIM, E. Biscoito Globo tem defesa apaixonada nas redes sociais. O Globo, Rio de Janeiro, 2016. Disponível em: https://oglobo.globo.com/rio/biscoito-globo-temdefesa-apaixonada-nas-redes-sociais-19938373. Acesso em: 28 jul. 2020. 



\title{
ALIMENTAÇÃO, DIREITOS HUMANOS E FLUXOS MIGRATÓRIOS ${ }^{1}$
}

\author{
CAROLINE FILLA ROSANELI \\ ANNA SILVIA PENTEADO SETTI DA ROCHA \\ TATYANA SCHEILA FRIEDRICH \\ RODRIGO ALVARENGA
}

\section{INTRODUÇÃO}

O processo de globalização tem se ampliado ao longo dos anos e vem trazendo consigo desafios sobre a mobilidade humana e seu acolhimento nos mais diversos países. Os números são expressivos e exigem providências.

O Alto Comissariado das Nações Unidas para Refugiados (ACNUR), em seu último relatório, denominado Tendências Globais, demonstra que mais de 79,5 milhões de pessoas foram forçadas a se deslocarem, sendo 26 milhões são refugiados, $40 \%$ ou seja, cerca de 34 milhões são crianças ou jovens abaixo de 18 anos, 45,7 milhões são deslocados internos, e a maioria dos refugiados está em países vizinhos e em desenvolvimento. (GLOBAL..., 2020)

1 Pesquisa derivada de estudos dos Grupos de Pesquisa "Saúde Pública, Bioética e Direitos Humanos" e "Direitos humanos e fluxo migratórios" da Pontifícia Universidade Católica do Paraná em parceria com o Programa de Extensão Política Migratória e Universidade Brasileira da Universidade Federal do Paraná. 
Em relação aos migrantes econômicos, o relatório bienal realizado pelo Departamento de Assuntos Econômicos e Sociais da Organização das Nações Unidas (ONU), relata que o número de migrantes internacionais atingiu cerca de 272 milhões em todo mundo em 2019, o que significa um aumento de 51 milhões desde 2010. Os migrantes internacionais representam atualmente 3,5\% da população global, sendo as regiões de destino à Europa (82 milhões), América do Norte (49 milhões), norte da África e Ásia Ocidental (49 milhões). Os migrantes que procuram países desenvolvidos subiram de 9,6\% em 2000 e 14\% em 2017. (ORGANIZAÇÃO DA NAÇÕES UNIDAS, 2019)

No Brasil de 2011 a 2018, considerando todos os amparos legais, foram registrados 774,2 mil imigrantes. Os fluxos migratórios são compostos na sua maioria por pessoas do sexo masculino, jovens e com nível de escolaridade médio e superior. As principais nacionalidades registradas entre 2010 e 2018 foram haitianos, bolivianos, venezuelanos, colombianos, argentinos, chineses, portugueses e peruanos, respectivamente. Em 2018 predominaram os fluxos oriundos da Venezuela e Haiti. As regiões que mais recebem migrantes são a Sudeste, com 55,1\%, seguida da Região Sul, com 20,5\%. Quando chegam ao Brasil as principais atividades econômicas que exercem com carteira assinada são na indústria e no comércio. Para os que desfrutam dessa possibilidade, a média da remuneração é em torno de 1,5 salário mínimo, porém muitos conseguem apenas na informalidade a sobrevivência. (CAVALCANTI et al., 2019)

As barreiras enfrentadas na chegada ao Brasil são o acolhimento moradia e alimentação -, idioma, preconceito e xenofobia, que se ampliam quando buscam inserção social, acesso aos cursos de português e no mercado de trabalho. Para migrantes que estão situação de extrema fragilidade e vulnerabilidade essas barreiras são ainda mais vivenciadas, segundo Silva e Fernandes (2017). As necessidades mais básicas no início do processo de integração ao Brasil são lugar onde dormir nas primeiras noites, atendimento médico de emergência, doação de roupas e itens de necessidade, aulas de português, orientações jurídicas e indicações de trabalho.

$\mathrm{O}$ direito ao movimento migratório territorial e subjetivo deveria ser protegido pelos Estados com estratégias considerando o respeito à cultura e diversidade, com base na não estigmatização e não discriminação e, além disso, acesso seguro à alimentação como um direito humano fundamental. 
A migração pela fome e pobreza coloca em evidência as incapacidades de produção e de trabalho do país de origem. As mudanças climáticas também causam efeito na alimentação e na migração. Diante de cenários devastadores, a dignidade humana deve ser sempre levada em consideração no diálogo entre os Estados, com vistas a evitar essa violência, buscando alternativas para essa população e criando outra realidade. Os tratados internacionais tendem a forçar os países a acolherem os refugiados, mas os migrantes econômicos e ambientais não encontram o mesmo tipo de proteção legal.

Nos fluxos migratórios, o direito de se alimentar de forma justa, segura, e em quantidade e qualidades suficientes são frequentemente violados. A fome e suas devastações em relação ao corpo e à dignidade humana, por vezes, são o principal motivo dos deslocamentos humanos, em que sobrevivência e acesso ao alimento são fatores de estímulo, além da busca por justiça e pelas liberdades fundamentais.

Essas fragilidades de efetivação dos direitos humanos da população migrante é uma barreira moral que necessita de diálogos e cooperação internacional para que o acesso à alimentação, de forma segura e digna, possa parar de atormentar a vida e reconhecer e acolher os vulneráveis.

No agravamento da crise migratória pode se perceber que a sociedade tende a promover uma ética egoísta e excludente, que afronta a sobrevivência humana. Portanto, este capítulo apresenta uma reflexão sobre as barreiras existentes no acesso ao alimento no contexto migratório, apontando quais as potencialidades para se enfrentar esse desafio emergencial, visto que a fome é uma das principais causas de morte e desamparo do nosso planeta, que mata silenciosamente os corpos mais vulneráveis.

Dentro desse contexto, este capítulo traz a discussão sobre a violação do direito de se alimentar nos fluxos migratórios, fazendo reflexões sobre a situação e os números da migração no Brasil e no mundo e as regulamentações jurídicas que lhes destinam. Analisa na sequência as vulnerabilidades, com ênfase na fome e na insegurança alimentar, olhadas sob suas inúmeras dimensões e seu aspecto cultural, levando em consideração que a aculturação e a fome são importantes barreiras enfrentadas também pelos migrantes. Por fim, apresenta o acolhimento e hospitalidade, em sua dimensão tanto filosófica e quanto prática, mas sempre como um dever moral e ético da sociedade, sobretudo para com 
o outro, que não pertence originariamente, mas que chega e se instala nessa sociedade.

\section{A MIGRAÇÃO NO CONTEXTO ATUAL}

A humanidade está enfrentando os maiores níveis de deslocamentos mundial já registrados, em que mais de 70 milhões de pessoas foram forçadas deixar suas casas, sendo que a cada minuto, 25 pessoas são deslocadas à força em decorrência de conflitos ou perseguições. (GLOBAL..., 2018) Nos fluxos migratórios, envolvendo migrantes ou refugiados, o direito de se alimentar de forma justa, segura e em quantidade e qualidades suficientes, é frequentemente violado.

Existem mais de 258 milhões de migrantes em todo o mundo. Em 2017, havia 68,5 milhões de pessoas em deslocamento forçado em todo o mundo. Em 2016, os desastres relacionados ao clima e a água foram responsáveis por 23,5 milhões de deslocamentos. Estima-se que haja 1 bilhão de migrantes internos nos países em desenvolvimento, e $85 \%$ dos refugiados são hospedados em países em desenvolvimento. (FAO, 2018a)

Nos casos de deslocamentos prolongados, o tempo médio de deslocamento induzido por crises é de 17 anos. Até o final de 2015, em torno de 56 milhões - $85 \%$ do total deslocados em todo o mundo - estavam em deslocamento prolongado. Menos de um em cada 40 refugiados conseguem viver em situações de solução resolvidas dentro de três anos ou mais, mas $80 \%$ das crises de refugiados duram por dez anos ou mais. (FAO, 2016)

Diversas iniciativas internacionais vêm sendo realizadas, na tentativa de estabelecer critérios mínimos de proteção da pessoa, que se desloca pelas fronteiras dos Estados e de regulamentação desse cenário, sendo que algumas dessas iniciativas se tornaram um elenco de princípios e outras configuraram-se em instrumentos jurídicos vinculantes, enquanto tratado ou convenção internacional.

A Agenda 2030 para o Desenvolvimento Sustentável (ORGANIZAÇÃO DA NAÇÕES UNIDAS, 2015), reconhece que a migração internacional é de grande relevância para o desenvolvimento de países de origem, trânsito e destino. Nessa Agenda, os governos se comprometeram a facilitar a migração ordenada, segura, regular e responsável, inclusive a implementação políticas de migração eficazes (meta 10.7). A Agenda 2030 também busca promover normas trabalhistas para os trabalhadores migrantes e eliminar o tráfico de pessoas. 
Em 2016, a Assembleia Geral da ONU adotou a Declaração de Nova York para Refugiados e Migrantes, pedindo desenvolvimento de dois pactos globais em 2018. Um pacto para refugiados, preparado pela ACNUR e um pacto de migração, negociados pela Assembleia Geral, sendo que ambos foram realizados e subscritos. Assim, a Declaração de Nova York reafirmou o compromisso dos Estados para proteger os direitos humanos de todos os migrantes, independentemente do status. (UNITED NATIONS, 2017)

O relatório do Banco Mundial intitulado Shock Waves Managing the Impacts of Climate Change on Poverty, de 2016 (HALLEGATTE et al., 2016) aponta que nos países mais pobres, e em especial as mulheres e as crianças, são a primeira parcela da população mundial a sentir os efeitos da mudança climática, com o aumento de doenças; problemas de saúde; falta de alimentação; maior incidência de desnutrição e escassez de água; e ainda podem ser vítima do tráfico de seres humanos e das formas hediondas de exploração que isso implica. Os migrantes são frequentemente os primeiros a perder o emprego em caso de desaceleração econômica. Alguns trabalham por menor salário, por mais horas e em piores condições do que trabalhadores nativos. Embora a migração seja frequentemente uma experiência empoderadora, ao menos enquanto anseio, na prática ainda perduram muitas violações de direitos humanos, abuso e discriminação.

No Brasil, a Lei no 13.445 de 2017 instituiu a Lei de Migração, definindo o imigrante como a pessoa nacional de outro país ou apátrida que trabalha ou reside e se estabelece temporária ou definitivamente no país. Essa Lei dispõe sobre os direitos e os deveres do migrante e do visitante, regula a sua entrada e estada no país, estabelece princípios e diretrizes para as políticas públicas para o emigrante, e não prejudica a aplicação de normas internas e internacionais específicas sobre refugiados, asilados, agentes e pessoal diplomático ou consular, funcionários de organização internacional e seus familiares. Tal documento declara que a política migratória brasileira se rege pelo princípio da universalidade, indivisibilidade e interdependência dos direitos humanos, repudiando a xenofobia, o racismo e a quaisquer formas de discriminação. Também são diretrizes da atual lei brasileira, a não criminalização da migração e a acolhida humanitária, garantindo o direito à reunião familiar, a igualdade de tratamento e de oportunidade ao migrante e a seus familiares, além da inclusão social, laboral e produtiva do migrante por meio de políticas públicas. (BRASIL, 2017) 
A expressão "refugiado", por sua vez, apoia-se no direito internacional, precisamente no texto da Convenção das Nações Unidas relativa ao Estatuto dos Refugiados de 1951. Para o documento, refugiado é aquela pessoa que, possuída de um fundado temor de ser perseguido por razões de raça, religião, nacionalidade, por ser componente de um grupo social específico ou por suas opiniões políticas, encontra-se fora do país de sua nacionalidade ou residência e, por conta desse temor, não pode, ou não quer, receber o amparo daquele país ou a ele retornar. No Brasil, as normas sobre refúgio estão previstas na Lei $n^{\circ}$ 9.474/97.

O migrante, visto como um deslocamento voluntário, não se enquadra na Convenção de 1951 da ONU, ficando sem a proteção do Estatuto do Refugiado. As causas desta mobilidade são complexas, sendo que a fome e a pobreza são razões primordiais para a decisão de migrar. A regulamentação da migração se dá pelo direito interno dos Estados e a proteção internacional do migrante se dá por meio dos direitos humanos, sendo que são justamente esses direitos que são violados nos países de origem.

A migração, seus propulsores e impactos têm num dos seus maiores desafios a erradicação da fome e das desigualdades. Para a Food and Agriculture Organization (FAO) (2019a), as principais causas de migração são a pobreza rural e insegurança alimentar; falta de emprego ou oportunidades de geração de renda; acesso limitado à proteção social; alterações climáticas; degradação dos recursos naturais; esgotamento dos recursos naturais devido à degradação ambiental ou mudança climática; conflitos; má governança e(ou) instabilidade política.

Compreender todas as desumanas dimensões da situação de pobreza e desigualdades é complexo. Os diferentes componentes que integram o conceito de pobreza, formulados desde o século XX, consideram que as violações pela sobrevivência física, necessidades básicas de acesso à alimentação, saúde, habitação e saneamento básico são os fatores que comprometem a vida humana. A privação abre novas possibilidades de análise de suas dimensões e os critérios que dispõem sobre as iniquidades sociais, vinculados a fatores de desigualdade de renda e a causas da pobreza, privam a pessoa de acesso às necessidades mais elementares de sobrevivência física. (ROSANELI et al., 2015)

$\mathrm{O}$ crescente avanço dos fluxos migratórios acontece por várias razões e pode criar desafios significativos, mas também, importantes recomeços. Entre 
os desafios incluem-se infraestruturas sociais avassaladoras, com a chegada inesperada de um número de pessoas e a morte de migrantes realizando viagens perigosas. Para mitigar as vulnerabilidades dos fluxos migratórios, o Pacto Global para Migração foi o primeiro acordo global da ONU sobre todas as dimensões que esse processo possui e que podem interferir nas vidas humanas, baseado em compartilhamento de responsabilidades, não discriminação e proteção aos direitos humanos, respeitando os valores da soberania dos Estados e a cultura dos países de destino e do migrante. (FAO, 2018b)

O Pacto Internacional das Nações Unidas sobre os Direitos Econômicos, Sociais e Culturais e o Pacto Internacional sobre os Direitos Civis e Políticos (ORGANIZAÇÃO DA NAÇÕES UNIDAS, 1966), apresenta a diversidade cultural como constituinte do patrimônio comum da humanidade, enfatizando, contudo, que esta não pode ser invocada às custas dos direitos humanos e das liberdades fundamentais. Da mesma forma, outro marco teórico, a Declaração Universal sobre Bioética e Direitos Humanos (UNESCO, 2005), conclama o "Respeito pela Diversidade Cultural e pelo Pluralismo", observando que este respeito invoca a não violação da dignidade humana e de todos direitos humanos elementares, incluindo a alimentação. Dessa forma, o processo migratório e os deslocamentos necessários nas migrações nacionais e internacionais colocam os sujeitos diante de rupturas e enfrentamentos nos quais sua sobrevivência são fatores sobrepostos a sua cultura e direitos.

O relatório da Comissão sobre a Sindemia global da obesidade, desnutrição e mudanças climáticas (THE GLOBAL..., 2019) traz importantes reflexões para decisões políticas sobre alimentação, sendo destinado a governos e agências internacionais, já que o acesso ao alimento de forma justa é um dos principais desafios da era atual. Mudanças climáticas estão na iminência de entrar em um caminho sem volta e, juntamente com a insegurança alimentar, colocam em risco grande parte da população mundial. Combinadas, as complexas interações dessas crises geram uma sindemia global, o que impõe a necessidade urgente de reformulação dos sistemas de alimentação que está impactando negativamente na qualidade da alimentação, na saúde, na cultura e no ambiente. Há diversas vulnerabilidades identificadas no documento, as quais só serão superadas com uma estratégia unificada de mitigação e adaptação mundial, demandando discussões éticas nas relações de acesso e consumo de alimentos, incorporando os direitos a vida, a alimentação e respeito a cultura e que sejam reconhecidos internacionalmente. 
Fenômenos mundiais como os fluxos migratórios apontam para a necessidade de se entender as realidades multiculturais criadas, bem como a relevância das identidades étnicas nas sociedades modernas, na busca de compreender as mudanças no modo de vida da população migrante. (CARRUS; PIRCHIO; MASTANDREA, 2018) Entre as dimensões culturais ligadas à etnia, as preferências alimentares, os métodos de preparação e as escolhas de consumo têm um papel central, com implicações relevantes em termos de sustentabilidade social e ambiental. Os alimentos são uma expressão fundamental das culturas humanas, longe de ser apenas um meio de sobrevivência. A relação entre seres humanos e alimentos nas sociedades modernas deve ser considerada por seu valor simbólico, ligado ao desenvolvimento do eu individual, social e coletivo. (CARRUS; PIRCHIO; MASTANDREA, 2018)

\section{FOME, INSEGURANÇA ALIMENTAR E VIOLAÇÕES DOS DIREITOS HUMANOS}

A promissora emergência de ideias no movimento pós-guerras tinha a concepção da luta contra a fome e de criação de um estado de segurança alimentar e nutricional que se asseguraria a vida dos povos. E isso passou a figurar como grandes desafios no ideário das sociedades civis e na agenda dos poderes públicos, sendo que ainda hoje, assinala-se um movimento no sentido de praticar a segurança alimentar como um referencial obrigatório dos direitos humanos, o que necessita ser resgatado. (BATISTA FILHO, 2003)

Estima-se que o número de pessoas subalimentadas no mundo passa de 820 milhões, o que equivale considerar que um em cada nove habitantes do planeta passam fome. Quase 151 milhões de crianças menores de cinco anos tiveram atraso em seu crescimento em 2017, devido ao acesso ao alimento insuficiente. (FAO, 2019b)

Segundo o relatório sobre o estado de segurança alimentar e nutricional ao redor do mundo (FAO, 2019b), o clima também tem grande influência na alimentação pelo mundo. O relatório defende que os efeitos cumulativos de mudanças climáticas, que vão além das fronteiras dos países, estão aniquilando todas as dimensões da segurança alimentar, tais como disponibilidade, acesso e consumo de alimentos. Seguramente, tais motivos também estão envolvidos nos fluxos migratórios em busca da garantia dos direitos a vida e dignidade humana. Os eventos climáticos extremos e prolongados 
diminuem a capacidade de sobrevivência, perda dos meios de vida e coloca os indivíduos em situações de indigência e grande dificuldade, e em casos mais graves, leva a inanição e morte. Nesse sentido, o documento aponta a necessidade de pensar em ações e soluções que reforcem a capacidade de adaptação de sistemas alimentícios e financiamento em larga escala e de programas de redução e gestão de riscos de catástrofes provenientes de mudanças climáticas.

A migração rural para cidade também dever ser assinalada como uma das principais estratégias de sobrevivência utilizadas em busca de outras condições para vida que são frequentemente difíceis, onde um processo seguro de acesso a alimentos é infrequente. Muitas dessas trajetórias são descritas como migrações internas, dentro de um mesmo país, onde são recebidos sem nenhuma estratégia de potencial gestão de riscos e se fixam, mesmo que provisoriamente, em locais empobrecidos, inseguros e incertos, desprovidos de qualquer proteção aos direitos humanos.

O Pacto internacional sobre os direitos econômicos, sociais e culturais (PIDESC), já citado neste trabalho, considera que "o direito à alimentação satisfatória se torna efetivo quando cada homem, mulher e criança, sozinho ou em coletivo, têm alcance físico e econômico a todo tempo à alimentação adequada ou aos meios para sua conquista”. (BRASIL, 1992) Considera, ainda, que é um direito fundamental de cada ser humano estar livre da fome, que é uma exigência humana e que deve ser atendida, mesmo em épocas de desastres, naturais ou não. (BRASIL, 1992)

Como garantir condições de vida e acesso à alimentação a populações de forma justa sem discriminação de origem cultural, econômica ou social, de etnia, gênero, idioma, religião, opção política ou de outra natureza em populações que estão em processo migratório? É a partir dessa vulnerabilidade que a segurança alimentar e nutricional e o direito humano a alimentação adequada e segura devem concentrar esforços e estratégias, sempre com vistas a superar tal realidade.

A condição de pobreza e a vivência da fome não permitem ao ser humano senão o contato com um padrão de consumo alimentar de natureza insuficiente e inadequada. Partindo do pressuposto que a fome é um fenômeno produzido pelo contexto político, social, histórico e econômico da sociedade, ela ameaça a vida e não somente traz os signos mais profundos do eu, no mundo habitual, como também não reduz esse fenômeno às 
relações funcionais do organismo, dando lugar à compreensão de uma identidade faminta na condição social.

Rosaneli e demais autores (2015) discutem que a fome guarda importante relação com a falta de empoderamento dos cidadãos vulnerados, considerando que a pobreza é um fenômeno complexo e multidimensional que priva grande parte da população mundial do acesso à alimentação, gerando enorme contingente humano que se vê fadado ao insuficiente desenvolvimento físico, psicológico e social.

Nas migrações, as desigualdades de oportunidades refletem as causas multidimensionais e multifatoriais da pobreza. Trata-se, portanto, de uma questão com consequências na esfera ética, pois a distribuição não ocorre por critérios justos, e essa injusta distribuição viola a dignidade humana de milhões de pessoas.

Como dito, observa-se também que a incapacidade para reduzir a fome no mundo está relacionada com o aumento de conflitos e violências em diversas partes do planeta, e que as iniciativas para manter a paz são fundamentais para sanar este dilema. (FAO, 2019a)

As diferentes e perversas formas de fome que alimentam o mundo contemporâneo, passam quase invisível perante tantas formas de violações que o ser humano enfrenta diariamente. A fome mais reconhecida é a falta de alimento diário constante e em populações vulneráveis. Os menos favorecidos que moram no campo e na cidade, e as vítimas de catástrofes são os mais vulnerados nestas situações de insegurança, e nas zonas de guerras são negadas todas as formas de alimentar a vida.

A vulnerabilidade surge da interseção de distintas desigualdades e estruturas de poder dispares e, portanto, se diferencia socialmente. Os homens e mulheres são afetados de diferentes formas de resiliência em crises migratórias. As mulheres, segundo a FAO (2019b), enfrentam maior angústia psicológica e emocional, redução da ingesta de alimentos, e em alguns casos, aumento da incidência de violência doméstica. Alimentação e alojamento são paliativos mínimos necessários que os Estados precisam desempenhar para soluções emergenciais.

Principalmente em migrações forçadas, as famílias passam por risco de insegurança alimentar e dificuldades econômicas, o que aumenta a severidade da insegurança alimentar associada à diminuição do consumo de uma dieta saudável, sendo que para crianças este risco é ainda maior. 


\section{CULTURA E MIGRAÇÃO: UMA REFLEXÃo NECESSÁRIA}

Os migrantes têm consigo diferentes normas culturais e práticas alimentares. Bailey (2017) analisa à luz da cultura material as ligações entre comida, pertença, comensalidade e cuidado. Para o autor, a comensalidade junto à etnia contempla um senso de comunidade e de laços comunitários mais fortes para os migrantes.

A partir dos novos fluxos migratórios, o cotidiano dos migrantes interligados à globalização pode trazer a força da padronização e a eliminação das diferenças, fazendo com que a aculturação seja necessária e vivida. Os processos identitários dos sujeitos migrantes vão se desintegrando e muitos passam a ver suas identidades de maneira múltipla com as demais culturas com as quais vão conviver em seus destinos. Mas a alimentação, como um elemento cultural presente no cotidiano, pode funcionar como importante mecanismo de autenticidade, pertencimento e adaptação, num mecanismo de resistência.

As tradições e identidades alimentares são, por vezes, o único pertencimento trazido além das lembranças de sua origem na migração. A alimentação é uma das estratégias de proteção e manutenção da cultura migratória na chegada a um novo local. $\mathrm{O}$ alimento se configura através de uma prática comunicativa a partir da qual criamos e compartilhamos significados. Nesse sistema alimentar, formado por decisões culturais como um código, o acesso à memória leva a lugares privilegiados, de resistência e sobrevivência.

Mas o que acontece quando diferentes conjuntos de normas e identidades culturais se encontram no mesmo indivíduo? Estudos com foco na experiência de migrantes descrevem as mudanças nos hábitos alimentares e no estilo de vida associados à migração, e como isso afeta o estado de saúde física e mental dos migrantes. (CARRUS; PIRCHIO; MASTANDREA, 2018)

Geralmente observa-se que os migrantes adotam os padrões alimentares do país anfitrião como parte de seu processo de aculturação. A própria sociedade de inserção do migrante, pode incluí-lo em processo de aculturação, ou seja, práticas e atitudes aculturadoras dominantes como alimentos de fontes economicamente mais baratas e nutricionalmente menos favoráveis à saúde. (CARRUS; PIRCHIO; MASTANDREA, 2018)

Para Mesoudi (2018), os migrantes ou seus descendentes podem se aculturar aos comportamentos locais por meio de processos de aprendizado 
social em direção aos valores culturais da sociedade adotada. No entanto, há pouco entendimento da dinâmica em nível individual subjacente a essas mudanças no nível da população.

No processo de aculturação pode haver mudanças sociopsicológicas de adaptação a um novo meio cultural, mediado por fatores sociais, demográficos e econômicos e pelo desenvolvimento de estilos de vida individuais. Enquanto a aculturação implica teoricamente mudanças nos indivíduos pertencentes ao grupo minoritário e na cultura hospedeira, no entanto, a maior parte da literatura se concentra nas mudanças dos migrantes devido à adaptação ao seu novo país. (CARRUS; PIRCHIO; MASTANDREA, 2018; MESOUDI, 2018)

Na concepção de Hall (2003), as experiências alimentares e indenitárias em outras culturas são semelhantes de estranhamento e desnaturalização. As identidades são pontos de identificação construídos por meio de diferenças e semelhanças entre os sujeitos. A alteridade aqui é vista como identidade como uma narrativa criada a partir do ponto de vista do "outro", e acredita que o reconhecimento de ser algo ou alguém específico surge com, e através, da diferença, principalmente na diáspora.

Ngongalah e demais autores (2018) relatam perfil de mulheres africanas migrantes para países de alto nível socioeconômico, e trazem uma longa discussão da aculturação da alimentação quando inseridos numa nova sociedade. As alterações ocorrem nos padrões e práticas alimentares das migrantes em busca por preservar seus comportamentos alimentares tradicionais. Porém, na fase pós-migração o consumo é descrito como limitantes pois os alimentos não estavam disponíveis ou eram escassos, como por exemplo os vegetais comumente consumidos na África - folhas de batata-doce, folhas de mandioca, amaranto e abóbora foram relatados. Mudanças na rotina de métodos de cozimento, sabor e textura também foram experiências relatas para se adaptar à nova cultura. A quantidade de refeições e de alimentos consumidos também foram mudanças de comportamentos enfrentadas. No entanto, a disponibilidade de alimentos baratos e não saudáveis foi uma barreira para comportamentos alimentares saudáveis, que influenciavam as mulheres a comer mais, cozinhar menos e consumir mais lanches, adotando padrões alimentares biculturais, com uma sobreposição entre o novo padrão e as práticas alimentares tradicionais.

Osei-Kwasi e demais autores (2017), também identificaram um processo de aculturação alimentar quando grupos de migrantes adotam os padrões 
alimentares do país anfitrião, demonstrando a complexidade da mudança alimentar, indicando que não é um processo linear e depende de vários fatores. A transição para aculturação de estilos alimentares pode ser motivada pela dificuldade de encontrar produtos alimentícios das culturas originais, além de frutas e vegetais frescos, mas também pode estar vinculado a recursos espaciais específicos dos ambientes da vida cotidiana. (CARRUS; PIRCHIO; MASTANDREA, 2018)

Para promover acesso a dietas mais saudáveis, é necessário entender os fatores que determinam os comportamentos alimentares na população migrante. Osei-Kwasi e demais autores (2016), fizeram um mapeamento de fatores que influenciam o comportamento alimentar entre grupos minoritários étnicos que vivem na Europa, que se encontra com uma população crescente desses grupos migrantes, cujos comportamentos alimentares são potencialmente preocupantes para a saúde pública. Os fatores que influenciaram o comportamento alimentar perceptíveis foram divididos em sete grupos: ambiente social e cultural (16 fatores); crenças e percepções alimentares (11 fatores); psicossocial (9 fatores); recursos sociais e materiais (5 fatores); acessibilidade à alimentação (10 fatores); contexto de migração (7 fatores) e o corpo (5 fatores). Porém, os autores salientam que novas pesquisas necessitam explorar os mecanismos subjacentes que moldam os comportamentos alimentares de populações migrantes.

Para Sanou e demais autores (2014), há lacunas persistentes no conhecimento da saúde nutricional, criando assim uma barreira ao avanço da promoção da saúde e à obtenção da máxima equidade em saúde de imigrantes analisados num estudo no Canadá. Cinco prioridades na análise desses pesquisadores são necessárias identificar, incluindo: a) riscos e benefícios associados a alimentos tradicionais ou étnicos; b) acesso e alcance aos alimentos pelos imigrantes; c) mecanismos e estratégias de enfrentamento para a segurança alimentar; d) mecanismos de escolha de alimentos em famílias imigrantes; e e) estratégias de promoção da saúde que trabalham para populações imigrantes.

Para Popovic-Lipovac e Strasser (2015) há fatores que afetam as mudanças na dieta das mulheres imigrantes trazendo consequências para a saúde dessa população. Elementos como estilo de vida mais ocupado, falta de relações sociais, maior nível de estresse, preferências das crianças, sabor, insegurança alimentar, falta de alimentos tradicionais entre outras barreiras 
podem resultar em dietas com alto teor de gordura e açúcar, baixo consumo de frutas e vegetais, porções maiores e inatividade física. Essas mudanças alimentares desfavoráveis podem, por sua vez, causar doenças crônicas, promovendo impactos negativos a saúde dos migrantes.

Outro foco, além do acesso de populações que já estão fixas, mesmo que temporariamente nas migrações, são de populações que estão em refúgio migratório e transitório, como em assentamentos. Para essa população a insegurança alimentar é um fator limitante da sobrevivência.

A insegurança alimentar foi descrita associada ao uso de violência por parte do cuidador contra adolescentes refugiados na África, devido ao estresse relacionado à deterioração do bem-estar da família, assentados em um contexto de múltiplas ondas de deslocamento e conflito contínuo. As necessidades são básicas e imediatas dos refugiados, mas podem conflitar com as necessidades contínuas dos refugiados previamente migrantes. As implicações políticas demonstradas por Meyer e demais autores (2019) incluem a necessidade de entender conflitos e divisões nas populações refugiadas e fornecer apoio a mecanismos de proteção baseados na comunidade para garantir que as mudanças no apoio humanitário não afetem negativamente as necessidades de proteção dos migrantes.

\section{ALIMENTAÇÃO, ACOLHIMENTO E HOSPITALIDADE}

As dificuldades de inserção de uma pessoa em diferentes culturas, devem perpassar por uma hospitalidade aos estrangeiros que caminha lado a lado com a construção histórica e imagética de mundo harmonioso e sem preconceitos, e que necessita da responsabilidade ética da sociedade no acolhimento. As migrações buscam nos direitos humanos dos migrantes a compreensão e amparo sobre exclusão e negação dos direitos. Para Silva e Fernandes (2017), as novas formas de mobilidade no mundo necessitam incluir maior proteção e inclusão aos povos, garantindo sua sobrevivência enquanto indivíduos ou grupos, sem nenhuma forma de discriminação, incluindo xenofobia, racismo e intolerância.

Segundo Martine (2005), a expansão dos meios de comunicação e de transporte, a propulsão da economia de diversos países em desenvolvimento, guerras regionais, situações de instabilidade política e catástrofes naturais encontram-se na origem de um deslocamento populacional cuja 
causa fundamental é a globalização capitalista. Exceto no caso dos conflitos armados e dos desastres naturais, a globalização é o principal fator que ativa os movimentos migratórios entre países e determina seus contornos.

Gomarasca (2017) questiona se é compatível o direito do Estado soberano de controlar as próprias fronteiras em relação a migração. $\mathrm{O}$ autor ainda chama a atenção para o imperativo da prevenção e da proteção necessárias nos fluxos migratórios, mesmo que combinado com o princípio da solidariedade e da partilha equitativa das responsabilidades, porém, existe ou não a possibilidade de justificar uma obrigação moral de acolher quem decide migrar e, a quem é forçado a fazê-lo? Como definir as fronteiras entre os que estão dentro e os que estão fora do espaço jurídico-político da cidadania?

A negação do direito à alimentação da população migrante exige melhor compreensão, sendo necessária uma reflexão sobre como isso pode ser explicado, a fim de tornar possível o desenvolvimento das estratégias de atuação que possam gerar a mudança do cenário generalizado de violações de direitos humanos. O ponto de partida da análise é a relação entre corpo e alimentação, considerando os aspectos físicos da nutrição corporal numa perspectiva biológica e os limites desse reducionismo, com o objetivo de possibilitar o reconhecimento da alteridade pela ressignificação do corpo e da subjetividade.

Quando se trata da alimentação e de sua escassez ou falta, a tendência é considerar apenas o aspecto da nutrição do corpo, daquilo que é biologicamente necessário para se manter um corpo vivo e saudável, ignorando aquilo que culturalmente envolve o ato de alimentar-se. Embora o corpo dependa do fornecimento de energia para manter-se vivo, o direito à alimentação envolve muito mais do que sua manutenção vital, "este direito estabelece a necessidade de políticas econômicas, sociais, ecológicas, educacionais, culturais e, em última (ou em primeira?) instância de referenciais éticos para sua validação”. (BATISTA FILHO, 2010, p. 154)

Apesar disso, a fome e a insegurança alimentar ainda se constituem como verdadeiras ameaças à dignidade da vida humana, principalmente no contexto de crise política, econômica e social da atualidade. No caso das migrações forçadas, a situação é ainda mais grave, em função da vulnerabilidade gerada pela perda da condição de cidadania, xenofobia, e os próprios deslocamentos que acabam sendo realizados sob condições de penúria e miséria em grande parte dos casos. Torna-se evidente a distância entre o direito na sua formulação jurídico política, e o direito na sua 
efetividade, sendo necessária uma reflexão ética a respeito do porquê isso acontece. Deve-se considerar a situação não apenas a partir daquilo que são os problemas de natureza política e de gestão dos fluxos migratórios, mas também as relações humanas e os problemas de ordem moral que impedem o acolhimento ético.

Diante da fome do corpo do outro, que é percebido como estranho e despido de sua humanidade, não se vê mais do que apenas um corpo que se desfalece pela falta de nutrição, algo que não desperta o senso moral e nem compromete a sociedade na busca de uma solução para o problema de tantas pessoas. Nesse sentido, a fome e a insegurança alimentar são problemas que precisam ser considerados na esfera intersubjetiva da comensalidade, na qual se manifesta a hospitalidade em sua condição mais pura. $\mathrm{O}$ ato de alimentar-se é propriamente, embora não exclusivamente, uma experiência que se realiza em grupo, e marca ritualisticamente o rompimento da barreira do estranhamento, pelo oferecimento de alimento ao outro.

Nesse sentido, existe uma relação direta entre alimentação e hospitalidade, mas que para ser vivida na sua integralidade requer uma forma de perceber o outro que esteja para além do reducionismo do corpo como objeto, que impede a experiência intersubjetiva da coexistência no sentar-se a mesma mesa. A hospitalidade, segundo Derrida (2000) é incorporada por limites e normas de acordo com cada cultura, porém, o estrangeiro é, antes de tudo, um mistério, tanto pode ser um hóspede quanto um inimigo. Por isso, Derrida (2000) enfatiza que a principal característica da hospitalidade é a abertura para o outro, a abertura moral para o estranho, para que se efetive o direito de ser bem-vindo.

Retomando as teses de Lévinas (1980) sobre as relações éticas e o sentido mais profundo da falta de acolhimento do outro, Derrida procura aprofundar a investigação sobre a questão da hospitalidade. A ausência de pátria comum faz do outro - o Estrangeiro. Esse Estrangeiro que perturba o "em sua casa”. Mas o Estrangeiro quer dizer também o livre. Sobre ele não posso poder, porquanto escapa ao meu domínio num aspecto essencial, mesmo que eu disponha dele: é que ele não está inteiramente no meu lugar. Mas eu, que não tenho conceito comum com o Estrangeiro, sou, tal como ele, sem gênero. Somos o Mesmo e o Outro. (LÉVINAS, 1980, p. 26-27)

A ética do acolhimento consiste, justamente, no reconhecimento da transcendência de outrem, na sua irredutibilidade a lógica do mesmo, pela 
afirmação de sua radical diferença. De acordo com Lévinas (1980, p. 30), “O acolhimento do Outro pelo Mesmo, de Outrem por Mim produz-se concretamente como a impugnação do Mesmo pelo Outro, isto é, como a ética que cumpre a essência crítica do saber”. A hospitalidade, nesse sentido, ocorre quando é possível suspender o julgamento automático do ego sobre o diferente, o estranho, admitindo a transcendência de outrem, a fim de possibilitar uma resposta ética de acolhimento, que se traduz pela tarefa moral de alimentar e possibilitar a experiência intersubjetiva de compartilhamento do alimento à mesma mesa. Para que isso aconteça, é preciso que a tendência de fazer do outro um corpo objeto, por meio da excessiva racionalização e objetivação, decorrentes do solipsismo da consciência, seja superada pelo reconhecimento da transcendência do corpo fenomenal frente aos limites impostos pelo pensamento objetivo.

Na perspectiva de Derrida (2003), a hospitalidade encarna a radicalidade desse grau de acolhimento, que faz com que ela não se restrinja apenas às pessoas conhecidas e com as quais se tem algum grau de parentesco, ou seja, uma hospitalidade condicionada, pois o sentido mais profundo da hospitalidade está justamente na sua relação direta com o acolhimento do estrangeiro enquanto estranho. A hospitalidade absoluta exige "que eu lhe ceda lugar, que eu o deixe vir, que o deixe chegar, e ter lugar no lugar que eu ofereço a ele, sem exigir dele nem reciprocidade (a entrada num pacto), nem mesmo seu nome”. (DERRIDA, 2003, p. 23-25, grifo do autor) Quão difícil é essa tarefa de acolhimento quando aquilo que se espera nem chega a esse ponto, mas consiste apenas em procurar garantir o direito mais básico e fundamental à vida e à alimentação?

\section{CONSIDERAÇÕES FINAIS}

A ausência de hospitalidade na atualidade, que se expressa pelas medidas de contenção dos fluxos migratórios, por meio de práticas que consistem em tornar difícil a vida do migrante, como estratégia de desencorajamento de novos fluxos, não é apenas a negação do acolhimento, mas a violação de uma condição humana fundamental. Condição que se encontra para além da pretensão de um saber do Eu sobre o Outro, e do Outro sobre o Eu, sendo justamente nessa impossibilidade teórica de uma definição que se faz o humano e se constitui a ética da hospitalidade. 
Dessa maneira, compreende-se que o fornecimento de alimento atende apenas em parte a perspectiva do acolhimento hospitaleiro, visto que o Outro não pode ser reduzido a um objeto que, tal como uma máquina, funciona se tiver a energia necessária para fazê-lo. É preciso considerar que o direito à alimentação por parte dos migrantes e refugiados inclui a necessidade de um olhar que transcenda a pura análise fria e calculista da gestão da desigualdade e da pobreza, que considere os traços culturais de cada pessoa não por comparação a cultura local, a fim de classificá-la como inferior ou superior, e a partir disso, decidir qual política de fronteira assumir.

Faz-se necessário reconhecer que a subjetividade humana se constitui justamente nessa vulnerabilidade da exposição aos outros, vulnerabilidade que nos iguala e por isso mesmo, desperta para a responsabilidade com aquele que tem fome.

\section{REFERÊNCIAS}

BAILEY, A. The migrant suitcase: Food, belonging and commensality among Indian migrants in The Netherlands. Apetite, Bethesda, n. 110, p. 51-60, 2017.

BATISTA FILHO, M. Da fome à segurança alimentar: retrospecto e visão prospectiva. Caderno de Saúde Pública, Rio de Janeiro, v. 19, n. 4, p. 872-873, 2003.

BATISTA FILHO, M. Direito à alimentação. Revista Brasileira de Saúde Materno Infantil, Recife, v. 10, n. 2, p. 153-154, 2010.

BRASIL. Decreto ${ }^{\circ} 59$, de 6 julho de 1992. Pacto Internacional sobre direitos econômicos, sociais e culturais. Diário Oficial da União: seção 1, Brasília, DF, 7 jul. 1992. Disponível em: http://www.planalto.gov.br/ccivil_03/decreto/1990-1994/ d0591.htm. Acesso em: 24 set. 2019.

BRASIL. Lei $n^{0}$ 9.474, de 22 de julho de 1997. Define mecanismos para a implementação do Estatuto dos Refugiados de 1951, e determina outras providências. Diário Oficial da União, Brasília, DF, 23 jul. 1997.

BRASIL. Lei $\mathrm{n}^{\circ}$ 13.445, de 24 de maio de 2017. Institui a Lei da Migração. Diário Oficial da União: seção 1, Brasília, DF, 25 maio. 2017. Disponível em: http://www. planalto.gov.br/ccivil_03/_ato2015-2018/2017/lei/113445.htm. Acesso em: 24 set. 2019.

CARRUS, G.; PIRCHIO, S.; MASTANDREA, S. Social-Cultural Processes and Urban Affordances for Healthy and Sustainable Food Consumption. Frontiers in Psychology, Lausanne, n. 9, p. 1-9, 2018. 
CAVALCANTI, L.; OLIVEIRA, T.; MACÊDO, M. et al. Resumo Executivo: imigração e refúgio no Brasil: a inserção do imigrante: solicitante de refúgio e refugiado no mercado de trabalho formal: observatório das migrações internacionais. Brasília, DF: OBMigra, 2019. Disponível em: https://portaldeimigracao.mj.gov.br/pt/dados/ relatorios-a. Acesso em: 13 dez. 2019.

DERRIDA, J. Anne Dufourmantelle convida Jacques Derrida a falar Da Hospitalidade. São Paulo: Escuta, 2003.

DERRIDA, J. Hostipitality. Angelaki, London, v. 5, n. 3, p. 3-18, 2000.

FAO. Food and Agriculture Organization of the United Nations. FAO and Migration. FAO, Rome, 2019a. Disponível em: http://www.fao.org/migration/en/. Acesso em: 24 set. 2019.

FAO. Food and Agriculture Organization of the United Nations. FAO Migration Framework: in Brief. Rome: FAO, 2018a. Disponível em: http://www.fao.org/3/ CA2717EN/ca2717en.pdf. Acesso em: 24 set. 2019.

FAO. Food and Agriculture Organization of the United Nations. Migration and Protracted Crises: addressing the root causes and building resilient agricultural livelihoods. Rome: FAO, 2016. Disponível em: http://www.fao.org/3/a-i6101e.pdf. Acesso em: 24 set. 2019.

FAO. Food and Agriculture Organization of the United Nations. The State of Food Security and Nutrition in the World 2019: safeguarding against economic slowdowns and downturns.

FAO: Rome, 2019b.

FAO. Food and Agriculture Organization of the United Nations. The Linkages between Migration, Agriculture, Food Security and Rural Development. Rome: FAO, 2018b. Disponível em: http://www.fao.org/3/CA0922EN/CA0922EN.pdf. Acesso em: 24 set. 2019.

GLOBAL Trends: forced displacement in 2018. UNHCR, Genebra, 2018. Disponível em: https://www.unhcr.org/5d08d7ee7.pdf. Acesso em: 24 set. 2019.

GLOBAL Trends: forced displacement in 2019. UNHCR, Copenhagen, 2020. Disponível em: https://www.unhcr.org/5ee200e37/\# $\mathrm{ga}=2.106453248 .287084822 .1599572038-528066163.1599572038$. Acesso em: 02 set. 2020 .

GOMARASCA, P. Direito de excluir ou dever de acolher?: a migração forçada como questão ética. REMHU, Brasília, DF, v. 25, n. 50, p. 11-24, 2017.

HALL, S. Da diáspora: identidades e mediações culturais. Belo Horizonte: Ed. UFMG, 2003.

HALLEGATTE, S.; BANGALORE, M.; BONZANIGO, L. et al. Shock Waves: managing the impacts of climate change on poverty. Washington, D. C: World Bank, 2016. 
LÉVINAS, E. De outro modo que ser ou para lá da essência. Lisboa: Centro de Filosofia da Universidade de Lisboa, 2011.

LÉVINAS, E. Totalidade e Infinito. Lisboa: Edições 70, 1980.

MARTINE, G. A globalização inacabada, migrações internacionais e pobreza no século 21. São Paulo Em Perspectiva, São Paulo, v. 19, n. 3, p. 3-22, 2005.

MESOUDI, A. Migration, acculturation, and the maintenance of between-group cultural variation. PLoS ONE, San Francisco, v. 13, n. 10, p. 1-23, 2018.

MEYER, S. R.; MEYER, E.; BANGIRANA, C. et al. Protection and well-being of adolescent refugees in the context of a humanitarian crisis: perceptions from South Sudanese refugees in Uganda. Social Science \& Medicine, Oxford, v. 221, p. 79-86, 2019 .

NGONGALAH, L.; RANKIN, J.; RAPLEY, T. et al. Dietary and Physical Activity Behaviours in African Migrant Women Living in High Income Countries: a systematic review and framework synthesis. Nutrients, Basel, v. 10, n. 8, p. 1-23, 2018

ORGANIZAÇÃO DA NAÇÕES UNIDAS. Agenda 2030. Nações Unida Brasil, Brasília, DF, 2015. Disponível em: https://nacoesunidas.org/pos2015/agenda2030/. Acesso em: 10 set. 2019.

ORGANIZAÇÃO DA NAÇÕES UNIDAS. International Migrant Stocks 2019. United Nations, Washington, D. C, 2019. Disponível em: https://www.un.org/ en/development/desa/population/migration/data/estimates2/estimates19.asp. Acesso em: 24 set. 2019.

ORGANIZAÇÃO DA NAÇÕES UNIDAS. Pacto Internacional sobre os Direitos Econômicos, Sociais e Culturais. [S. l.: s. n.], 1966. Disponível em: http://www.unfpa. org.br/Arquivos/pacto_internacional.pdf. Acesso em: 24 set. 2019.

OSEI-KWASI, H. A.; NICOLAOU, M.; POWELL, K. et al. Systematic mapping review of the factors influencing dietary behaviour in ethnic minority groups living in Europe: a DEDIPAC study. International Journal of Behavioral Nutrition and Physical Activity, London, v. 13, n. 85, p. 1-17, 2016.

OSEI-KWASI, H. A.; POWELL, K.; NICOLAOU, M. et al. The influence of migration on dietary practices of Ghanaians living in the United Kingdom: a qualitative study. Annals of Human Biology, Abingdon, v. 44, n. 5, p. 454-463, 2017.

POPOVIC-LIPOVAC, A.; STRASSER, B. A Review on Changes in Food Habits Among Immigrant Women and Implications for Health. Journal of Immigrant and Minority Health, New York, v. 17, n. 2, p. 582-590, 2015.

ROSANELI, C. F.; RIBEIRO, A. L. C.; ASSIS, L. et al. A fragilidade humana diante da pobreza e da fome. Revista Bioética, Brasília, DF, v. 23, n. 1, p. 89-97, 2015. 
SANOU, D.; O'REILLY, E.; NGNIE-TETA, I. et al. Acculturation and Nutritional Health of Immigrants in Canada: a scoping review. Journal of Immigrant and Minority Health, New York, v. 16, n. 1, p. 24-34, 2014.

SILVA, F. R.; FERNANDES, D. Desafios enfrentados pelos imigrantes no processo de integração social na sociedade brasileira. Revista do Instituto de Ciências Humanas, Belo Horizonte, v. 13, n. 18, p. 50-64, 2017.

THE GLOBAL Syndemic of Obesity, Undernutrition, and Climate Change: the lancet commission report. The Lancet, New York, 27 jan. 2019. Disponível em: https://www.thelancet.com/commissions/global-syndemic. Acesso em: 10 set. 2019.

UNESCO. Organização das Nações Unidas para a Educação, Ciência e Cultura. Declaração Universal sobre Bioética e Direitos Humanos. Lisboa: UNESCO, 2005. Disponível em: https://unesdoc.unesco.org/ark:/48223/pf0000146180_por. Acesso em: 10 set. 2019.

UNITED NATIONS. Department of Economic and Social Affairs. International Migration Report 2017. New York: United Nations, 2017. Disponível em: https://www.un.org/en/development/desa/population/migration/publications/ migrationreport/docs/MigrationReport2017_Highlights.pdf. Acesso em: 10 set. 2019. 



\section{VIVÊNCIAS NA INTERFACE DOS CAMPOS DAALIMENTAÇÃO E EDUCAÇÃO'}

CAROLINA MUNIZ PESSANHA D'ALMEIDA DE BRITO

LETÍCIA DA SILVA COUTINHO

MARIA CLÁUDIA DA VEIGA SOARES CARVALHO

VERÔNICA OLIVEIRA FIGUEIREDO

\section{INTRODUÇÃO}

Os campos da Nutrição e Educação vêm sendo estudados sob diversas perspectivas, porém, ao nos aproximarmos de pesquisas (ALMEIDA, 2016; PAIVA et al., 2018; PINTO; ARAÚJO; SOUZA, 2016; SANTOS, 2005; SOUZA; LIMA; ), sob a lente das Ciências Sociais, observamos que práticas adotadas, em ambos, revelam certa impregnação de agentes e sistemas reprodutores de estruturas que mantém posições e condutas nas relações sociais. (BOURDIEU, 2014)

A atribuição de caráter, predominantemente, biológico e tecnicista à Nutrição impulsionou uma reflexão em torno da questão e, desse modo, a

1 O texto deriva do projeto de extensão “Direito humano à alimentação adequada para populações invisibilizadas: uma realidade dos gramachinhos” aprovado e financiado pelo edital PROFAEX/UFRJ 2018 e 2019 e aprovado pelo Comitê de Ética (CEP) em Pesquisa sob o número CAAE 87156418.1.0000.5257. 
comida e temas que circundam sua história, cultura, modos de produção, cenários políticos e sociais têm sido fundamentais na construção do conceito Alimentação (SILVA et al., 2010), sinalizando que as múltiplas interações dessas vertentes manifestam uma natureza holística do campo.

Não obstante, a Educação revela em si um sistema de ensino há muito perscrutado por autores das ciências humanas e sociais, os quais abordam, na relação educador-educando, elementos de dominação, imposição e colocam o alcance de um saber sob condições unidirecionais, inculcando ações pedagógicas com pouco ou nenhum espaço para reflexões. (BOURDIEU, 2014; FOUCAULT, 2013; FREIRE, 1994, 1999, 2011, 2014)

Nesse sentido, o aprendizado precisa ser experienciado de maneira que perpassa a experimentação pessoal, pois como posto por D’Ambrosio (2005), na prática os conhecimentos se consolidam e ganham sentido, gerando novos conhecimentos. E em vista deste contexto buscamos modos interativos e na contramão da educação tradicional, utilizando a educação alimentar como processo de incorporação de nova alimentação saudável construída na cultura local a partir de conteúdos de disciplinas convencionais do ensino básico. Essa experiência foi desenvolvida em processo contínuo de atividades de extensão universitária no curso de Nutrição da Universidade Federal do Rio de Janeiro (UFRJ).

Escolhemos um caminho que busca distanciar-se de um processo educativo tradicional, que tem como prática a transferência de conhecimento de um sujeito a outro, de modo unilateral e passivo, havendo nesse modelo uma proposta de educação bancária, que se opõe à curiosidade epistemológica, como dito por Freire (2011), sem a qual não se alcança o conhecimento ampliado do objeto. Esse modus operandi do processo educativo, em que um personagem detentor transfere conteúdo para um executor, remete a um aspecto próprio da cultura contemporânea que Foucault (2013) chama de "corpos dóceis". Em busca de uma prática disciplinar e, a partir dos corpos que ela controla, se organiza táticas, codifica-se as atividades e forma-se as aptidões e, assim "o treinamento dos escolares pode ser feito da mesma maneira: poucas palavras, nenhuma explicação, no máximo um silêncio total que só seria interrompido por sinais”. (FOUCAULT, 2013, p. 160)

Nessa perspectiva, acreditamos em ações que estimulem uma formação de indivíduos críticos (FREIRE, 2011), a partir de experiências na educação alimentar em consonância com o Direito Humano à Alimentação Adequada 
(DHAA) em um território de extrema pobreza, antigo aterro sanitário em Jardim Gramacho, Duque de Caxias-Rio de Janeiro (RJ), em que desenvolvemos a extensão universitária. Para tanto, é mister a compreensão do cotidiano de crianças e adolescentes que vivem nesse local e é nesse sentido, portanto, que a importância da palavra e do diálogo pode ser compreendida.

Quando tentamos um adestramento no diálogo, como fenômeno humano, se nos revela algo que já poderemos dizer ser ele mesmo: a palavra. Mas, ao encontrarmos a palavra, na análise do diálogo, como algo mais que um meio para que ele se faça, se nos impõe buscar, também, seus elementos constitutivos. (FREIRE, 1994, p. 44)

Numa posição de educador, a busca desses elementos requer considerar nossos próprios pré-conceitos dessas vivências, nos conduzindo a refletir sobre práticas adotadas no processo educativo, conforme colocado por Caregnato e Pinho (2013, p. 190):

[...] não somos neutros, somos seres sociais portadores de visões de mundo e de perspectivas de interpretações parciais, mesmo sendo altamente competentes em nossos conhecimentos e práticas educacionais. Temos preconceitos e práticas discriminatórias que só podem ser compreendidas e repensadas dentro de nossas trajetórias de historicidades individual e social. Tratar de nossas histórias, na perspectiva da diversidade cultural, é também enfrentar nossas limitações.

A partir de então, no contexto deste trabalho, o debate acerca da alimentação ganha centralidade nas abordagens educativas, de modo a envolver (e não desenvolver) crianças e adolescentes, enquanto sujeitos sociais que têm um lugar de fala e de escuta para além da comida. É nesse sentido que um caminho se abre para partilharmos nossas práticas e percepções na interface dos campos da Alimentação e Educação.

Assim, o presente trabalho tem como objetivo refletir, criticamente, sobre as vivências nas relações entre sujeitos, compreendendo que em meio às atividades, narrativas do público infanto-juvenil carregam percepções, falas, expectativas e histórias de vida. (BAMBERG; GEORGAKOPOLOU, 2008; BASTOS; BIAR, 2015; BECKER, 1994; LABOV, 1972; LINDE, 1993; 
RIESSMAN, 1993) Para tanto, descrevemos e analisamos situações que envolvem o pensar desde o território às práticas pedagógicas.

\section{DO TERRITÓRIO ÀS EXPERIÊNCIAS}

As experiências selecionadas para esse texto emergem das atividades do projeto de extensão "Direito humano à alimentação adequada para populações invisibilizadas: uma realidade dos gramachinhos”. A atuação do grupo, em Jardim Gramacho, é viabilizada pela parceria firmada, desde abril de 2018, com a Associação Projeto Gramachinhos, que propõe ações destinadas às famílias daquele lugar, com ênfase no público infantojuvenil. As atividades, em sua maioria, ocorrem em Jardim Gramacho, na sede da Associação, mas há também a execução de algumas delas nas dependências da UFRJ, campus fundão, como nas Oficinas Culinárias desenvolvidas no laboratório culinário do Restaurante Universitário Central. Os encontros, que acontecem frequentemente ao longo do ano, são previamente marcados e estruturados pelo grupo de extensionistas, e o público alvo são as crianças e adolescentes que frequentam as atividades de reforço escolar da Associação.

Jardim Gramacho, pertencente ao $1^{\circ}$ distrito do município de Duque de Caxias no Rio de Janeiro, é um território marcado por abrigar um aterro sanitário desativado em 2012, cujas características provocam uma reflexão sobre a vida naquele lugar, mediante à falta de infraestrutura urbana e à existência de grandes bolsões de pobreza (INSTITUTO BRASILEIRO DE ANÁLISES SOCIAIS E ECONÔMICAS, 2005), resultado de uma história pregressa e, ainda vivenciada, de processos de distinção social. Nesse cenário, as atividades do projeto de extensão ocorrem pela articulação de conteúdo de disciplinas convencionais do ensino básico com a educação alimentar na busca de ações que possam despertar interesse do público alvo, por meio de estratégias que valorizem a emancipação de sujeitos sociais (FREIRE, 2011) e, portanto, fomentam possíveis caminhos para alcançar o DHAA.

Assim, selecionamos experiências de educação alimentar vivenciadas na conjuntura do projeto de extensão e pesquisa, que constituíram o corpus de análise, para a chamada da Coletânea sob o título Corpos, identidades dissonantes e subjetividades em cenas de comensalidade e, a partir das mesmas, procuramos refletir, criticamente, sobre propostas de Educação Alimentar 
e Nutricional (EAN) em um contexto de extrema pobreza, uma vez que os guias de alimentação saudável e adequada não contemplam territórios com tal característica. Mediante a isso, o estudo busca problematizar questões relacionadas aos limites extremos e o que se preconiza em estratégias globais de alimentação saudável. Diante desse cenário, a pergunta norteadora é "Como podemos compreender as condições de saúde na prática quando não se compreende os anseios e sentidos da vida cotidiana de crianças e adolescentes de Jardim Gramacho?”.

Deste modo, adotamos um processo semelhante ao sugerido por Becker (1994), que reconhece as histórias de vida dos sujeitos como uma mensagem viva e rica em sentidos e significados. E, consideramos ainda, as narrativas como um discurso construído em diferentes contextos na ação de se contar histórias, vistas como funções complexas e comuns à experiência cotidiana, buscando compreender subjetividades. (BASTOS; BIAR, 2015) Esses autores revelam uma perspectiva de que as histórias de vida e experiências acumuladas articulam uma sociabilização entre sujeitos.

Nesse sentido, no presente trabalho, e sob a perspectiva do educador, ora ocupado pelas pesquisadoras, é que as vivências são contadas, à luz de uma reflexão crítica que produzimos nestas atividades extra escolares, que embora com componentes curriculares da Educação Básica, envolvem também uma troca de significados em torno da alimentação, uma reflexão que pode seguir uma visão ampliada sobre ensino aprendizagem, fora dos muros da universidade, nos termos de Paulo Freire (2011, p. 25) "Não há docência sem discência, as duas se explicam e seus sujeitos, apesar das diferenças que os conotam, não se reduzem à condição de objeto um do outro. Quem ensina aprende ao ensinar e quem aprende ensina ao aprender”.

No relato das experiências, os nomes dos sujeitos serão substituídos pelas palavras “criança” ou "adolescente”, em alguns casos seguida de um numeral, a fim de atender critérios éticos da pesquisa.

\section{UM OLHAR APROFUNDADO EM NOSSAS VIVÊNCIAS}

Pautadas em nossas vivências com o público, resgatamos narrativas no âmbito de algumas atividades educativas, apresentadas a seguir. Para tanto, buscamos dar espaço para fala do público, bem como apreender as reações e expressões, as quais instrumentalizam nossa reflexão. 
Organizamos as experiências em cinco partes: percepções e palavras que alimentam; a cozinha como um ambiente para diminuir obstáculos; a naturalização de uma violência; que direitos eu tenho: um convite à reflexão e a mudança possível permeada na prática. No primeiro, expomos o contato inicial do grupo com o local bem como uma das primeiras atividades realizadas na sede, a qual articula um conteúdo específico da disciplina de português e alimentação, com foco no respeito à linguagem do educando. No segundo, apresentamos duas dentre as quatro experiências de oficinas culinárias já realizadas, a primeira abarcando questões matemáticas e a segunda com ênfase nos sentidos percebidos a partir do sensorial e, em ambas, ressaltamos dificuldades e superações percebidas nas atividades. Já no relato intitulado como "A naturalização da violência”, partimos de um fato cotidiano para realçar tanto um problema quanto a busca de suas alternativas. Com o objetivo de explorar mais questões e reflexões sobre os direitos acessados por nosso público, selecionamos o relato "Que direitos eu tenho: um convite à reflexão". E por último, em "A mudança possível permeada na prática”, relatamos o impacto que a prática pode ter em nossas ações, quando nos permitimos vivenciá-las de maneira crítica.

\section{PERCEPÇÕES E PALAVRAS QUE ALIMENTAM}

Nossa aproximação com o campo ocorreu, num primeiro momento, pela visita à região, incluindo casas, ruas e comércio, com o auxílio de um dos coordenadores da Associação. Ao retornarmos para os arredores da sede, uma das crianças, moradora do local, percebendo a presença do coordenador, questionou se haveria alguma atividade no dia e, após respondermos positivamente, confirmamos que o horário seria às duas horas da tarde, entendendo que esta informação iria viabilizar sua participação. Logo, a criança ao perguntar: “mas que horas são duas horas?”, revelou que compartilhar informações, do modo como fazemos cotidianamente dentro dos muros da universidade, não seria simples.

Percebemos o desafio demonstrado pela criança de situar-se com base nas unidades de medida de tempo, com isso, apesar de não podermos afirmar a existência de uma ânsia em aprender as horas, compreendê-la o ajudaria a marcar o tempo. Nesse sentido, ao assumirmos um compromisso que possui data e horário, refletimos o quanto essa informação precisa fazer sentido 
para ela. Isso vai ao encontro do que Freire $(1994,2011)$ diz sobre partirmos de um acontecimento para pensar sobre temáticas a serem trabalhadas, mediante o diálogo entre educadores e educandos, não impondo a nossa visão de mundo numa transferência de conhecimento, mas sim alinhando-nos às questões que emanam na(da) coletividade.

Ainda em um momento de reconhecimento de práticas sociais presentes no grupo, observamos que as aulas de reforço escolar oferecidas pela Associação apresentavam um caráter expositivo, com pouca interação dialógica. E, nesse cenário, as carteiras escolares seguiam uma disposição enfileirada e as estratégias pedagógicas adotadas, tais como ditado e resolução de operações matemáticas no quadro branco, revelaram certa tendência para a prática de uma abordagem tradicional de ensino. Assim, em nossas ações optamos, de modo estratégico, por atividades coletivas, buscando o envolvimento do público no processo educativo e, apesar de imersos em um espaço de apoio escolar, com práticas sociais semelhantes à de uma escola, visamos trocar informações interdisciplinares associadas, de algum modo, ao comer.

Exemplo dessas atividades foi a ação pedagógica, contemplando a língua portuguesa, sendo realizada uma abordagem de construção de palavras, a partir de uma estruturação silábica. Para tanto, elaboramos uma atividade interativa, utilizando pequenos recortes de papéis coloridos com sílabas distintas e, por meio de uma atuação em grupos, o público foi incentivado a formar vocábulos referentes ao contexto culinário. Diante da participação, percebemos dúvidas sobre a grafia das palavras e, além disso, observamos que, apesar de termos planejado, nomes relativos ao contexto da alimentação, outros substantivos por eles construídos como "sacolher", "baço" e "asa" foram concebidos pelos sujeitos, possibilitando o exercício da criatividade.

A atividade realizada permite um pensar sobre as diversas possibilidades de criação e visões de mundo, conforme apontado por Freire (1999), o que nos leva a considerar que existem diferenças entre os educandos, ainda que numa mesma condição social, desviando nosso olhar para além de um erro ortográfico. Quando visto sob a ótica da educação bancária (FREIRE, 1994), o erro, ao fugir da correspondência esperada pelo educador, tende a ser discriminado, uma vez que essa estrutura de ensino está centrada na resposta. Seguindo, no entanto, a proposta de pluralizar a leitura de mundo, ao nos depararmos com um erro a reação deve se basear no respeito 
à linguagem e à cultura daquele que o cometeu. Há de ser ressaltado, no entanto, que esse respeito não reside em tomar o erro como sendo certo, mas está em compreendê-lo como uma etapa que se constitui importante na busca pelo acerto. (FREIRE, 2014) A partir do entendimento de que esse erro, ao ser trabalhado, pode gerar uma curiosidade no educando, ainda que ingênua, o mesmo pode abrir caminho para a curiosidade epistemológica, defendida por Freire (2011), colocando o conhecimento empírico como uma força motriz na transformação de "sacolher" em "sacolé". O que poderia ser interpretado como resultado negativo no contexto da língua portuguesa, julgamos ser proveitoso diante da percepção de Freire (2011), no que diz respeito ao fazer do educando, colocando o educador numa posição mais de facilitador do que de autoridade pedagógica.

\section{A COZINHA COMO UM AMBIENTE PARA DIMINUIR OBSTÁCULOS}

A culinária pode ser considerada uma estratégia que já foi legitimada pelo Guia alimentar para população brasileira do Ministério da Saúde (BRASIL, 2014) em prol de uma alimentação saudável, como uma possibilidade de articular distintos saberes globais com o universo de significação da cultura local, entrelaçando dimensões sensoriais, cognitivas e simbólicas, apresentando-se como uma ferramenta de interação dialógica. (DIEZ-GARCIA; CASTRO, 2011; MENEZES; MALDONADO, 2015) Nesse sentido, as oficinas culinárias foram, estrategicamente, um meio de suscitar tais dimensões em nossas práticas nesse estudo.

Nossa oficina foi realizada no laboratório culinário do Restaurante Universitário Central da UFRJ e contou com uma parte do público participante do Projeto Gramachinhos, que foi até a Universidade com ônibus fretado pela mesma. Toda a prática foi desenvolvida sob o tema cozinhar e calcular, valorizando a matemática no cotidiano de uma cozinha e, assim, buscando estimular este conhecimento no contexto da culinária, a partir das etapas de preparo e degustação, com suas respectivas experiências sensoriais. Durante a atividade, havia uma orientação pedagógica com exercícios matemáticos para cada grupo de crianças, cada qual responsável por receitas específicas. Assim, durante a produção, elas poderiam, por meio do contato com a balança, pesar, quantificar e anotar o rendimento total e a 
porção das preparações, aplicando, para isso, operações básicas da matemática. No entanto, observamos certa complexidade para a maioria dos participantes, uma vez que, para muitos, estas atividades matemáticas podem ser percebidas com certa dificuldade de apreensão. Apesar dos obstáculos no desenvolvimento da atividade, ao final, notamos por meio de relatos e abraços, que houve satisfação, entusiasmo e envolvimento.

Tal como Freire (2011) defende, é necessário um estímulo à participação, à curiosidade e ao fazer. Dentro desse contexto, percebemos que, em contraponto, nossas atividades foram impulsionadas em um ambiente novo para o grupo de crianças, de forma conjunta, utilizando a culinária como estratégia que possibilita novos fazeres. Dessa maneira, ainda que tenham dificuldades com o conteúdo de determinada disciplina, a estratégia proposta é uma forma de diminuir os obstáculos encontrados na assimilação desta, viabilizando uma educação alimentar através de atividades interdisciplinares. Nessa experiência pudemos ver a complexidade de ser um educador do diálogo e da relação de companheirismo com os educandos numa estrutura de poder presente em um restaurante universitário.

Em outra oficina culinária, cujo nome foi "Explorando os sentidos", também realizada no laboratório culinário do restaurante no âmbito da UFRJ, e que fora elaborada por conta do interesse demonstrado pelo público nessa estratégia, optamos por trabalhar com os sentidos, propondo despertar a curiosidade através do preparo de receitas selecionadas a partir de seus atributos sensoriais, sendo elas: bolo de espinafre, panqueca de beterraba, biscoito de morango, nhoque de cenoura e sorbet de manga.

Assim, ao cogitarmos preparar um bolo de espinafre, almejando o interesse das crianças, acabamos por criar uma situação-problema: a tentativa de convencê-las a experimentar. Mesmo diante da rejeição durante o preparo, a proposta em degustar o bolo foi aceita e, ao comentarem sobre suas impressões verbalizaram gostar da preparação. Apesar daqueles que realmente não gostaram, pode-se dizer que o resultado dessa estratégia foi satisfatório, pois diversas crianças que inicialmente reclamaram dos ingredientes envolvidos nas preparações, não só do espinafre, mas também da beterraba, por exemplo, alegando que "não gostavam" ou que "isso não iriam comer”, ao final da preparação, ao experimentarem, aprovaram e repetiram, afirmando que haviam mudado sua percepção. Foi possível ouvir diversos comentários como "o lá de casa não é gostoso assim não", que ao serem 
proferidos despertavam risadas e outros comentários como "tia, repete isso sempre” (referindo-se ao bolo). Desse modo, acreditamos que a atividade foi capaz de suscitar conhecimentos e vivências que perpassam por uma educação alimentar e nutricional que valoriza a degustação de comidas, promove comensalidade e troca de experiências por meio de estratégias de sensibilização, e que conduz para além de uma abordagem conteudista e estritamente curricular, entendendo que "o poder disciplinar é com efeito um poder que, em vez de se apropriar tem como função maior 'adestrar'; ou sem dúvida adestrar para retirar e se apropriar ainda mais e melhor”. (FOUCAULT, 2013, p. 164)

Do modo como se conduziu tal prática abarcou a ideia de que a degustação e a experimentação viabilizam, ao sujeito que degusta e experimenta, a oportunidade de considerar, aquilo a que degusta e experimenta, algo adequado ou não, dentro de suas individualidades, fugindo, assim, de uma concepção tecnicista de adestramento. Percebemos que o consentimento, a espontaneidade e a criatividade são elementos constituintes da prática executada, o que corrobora para o entendimento de que é possível escapar de um autoritarismo categórico quando se fala de uma nova alimentação. Partindo, então, desse olhar que fomenta o processo de apropriação, percebemos o quanto os educadores e educandos vão se (re)construindo na prática. Enquanto ocupamos o lugar de apresentar e propor preparações de formas e gostos diferentes dos habituais e eles aceitam prová-lo ou não, o que, em um primeiro momento, não os é atrativo, é notório que ambos os sujeitos desse processo podem ocupar um lugar de protagonista. No momento em que trazemos à discussão, o provar novas preparações e eles se expressam de forma crítica aos sabores e às apresentações, procuramos estimular a fala e a reflexão, colocada como narrativa ou simplesmente transferida sensorialmente na degustação.

\section{A NATURALIZAÇÃo DE UMA VIOLÊNCIA}

Em uma das visitas à sede do Projeto Gramachinhos, após a realização de todas as atividades propostas para o dia, uma menina de oito anos perguntou se poderia utilizar o material (papel e lápis) para desenhar. No meio de outros desenhos e rabiscos, identificamos que um deles se tratava da representação de uma arma. O que para nós motivou um olhar mais atencioso, e 
gerou reflexões, não pareceu ser incomum para a autora do desenho nem para as outras crianças que a observavam desenhar, pois aquele não passava de um desenho como qualquer outro.

De acordo com o artigo 79 do Estatuto da Criança e do Adolescente (ECA), Lei n 8.069, de 13 de julho de 1990: "As revistas e publicações destinadas ao público infanto juvenil não poderão conter ilustrações, fotografias, legendas, crônicas ou anúncios de bebidas alcoólicas, tabaco, armas e munições, e deverão respeitar os valores éticos e sociais da pessoa e da família”. (BRASIL, 1990, p. 21) Ao considerarmos este dispositivo legal, entendemos que embora essa criança esteja protegida por lei, pode haver uma exposição ao referido objeto e, possivelmente, de maneira intensa, pois o desenho demonstra a possibilidade da arma pertencer ao seu contexto social, o que nos faz refletir sobre a naturalização do uso de armas de fogo naquele território.

A experiência aqui colocada desempenhou papel importante na compreensão do contexto social desta localidade de Jardim Gramacho, pois ainda que seja visto como problemático, não deve ser visto como inexorável em sua totalidade. Ao encararmos tal realidade, entendemos que o fim de nossas ações não deve culminar em prescrições, isoladamente, ou mesmo se encerrar em uma análise crítica sobre o processo de educação nesta vivência, mas devem abrir caminhos para as possibilidades de educação alimentar. Essas possibilidades, no entanto, ainda que sejam pensadas abarcando a análise feita, vão para além dela, de modo tal que as diferenças culturais participem de um diálogo e de uma troca simbólica com protagonismo tanto do educador quanto do educando. Nesse sentido, abrimos espaço para a reflexão sobre o aceitar e entender as diferentes realidades dos sujeitos, sendo importante considerá-las ao longo de todo o processo, a fim de que se estabeleça uma criticidade própria (FREIRE, 2011), tornando possível uma construção coletiva na defesa do DHAA em seus mais variados contextos.

\section{QUE DIREITOS EU TENHO: UM CONVITE À REFLEXÃO}

A atividade intitulada como "Que direitos eu tenho?" ocorreu em um de nossos habituais encontros, na sede do Projeto Gramachinhos, e foi estruturada com o objetivo de ampliar a reflexão do público infantojuvenil sobre seus direitos. Nela, conversamos com o nosso público sobre o seu cotidiano 
para gerar reflexão sobre os direitos que lhes são concernentes, ressaltando, nesse contexto, a alimentação adequada, compreendendo, no entanto, a importância de realizar uma abordagem que inclua os Direitos Humanos como um todo, indo além do DHAA. Sendo essa uma das atividades realizadas pelo projeto de extensão, sua dinâmica foi pensada para melhor atendê-la, de maneira mais específica. Para isso, em nosso planejamento, optamos por trabalhar com os participantes com idade superior a 12 anos, pensando em uma maior fluidez na linguagem sobre tema. Entretanto, no dia da execução, algumas crianças foram incluídas na atividade mediante o fato de considerarmos displicente não abarcar todos aqueles que haviam se direcionado à sede do projeto, em Jardim Gramacho, com a finalidade de serem incluídos. Assim, optamos por dividir as crianças em três grupos, de acordo com suas idades.

A conversa com o grupo das crianças de menor idade, apesar de ser difícil em decorrência de uma inquietação própria da idade, gerou resultados propícios a algumas reflexões. Em meio a sucessivas tentativas de conquistar a atenção dessas crianças, tentamos abordar as perguntas norteadoras elaboradas em nosso roteiro as quais perpassavam pela educação, saúde, lazer, moradia e alimentação, no entanto, o que identificamos pareciam ser percepções pessimistas vindas delas mesmo. Quando questionadas sobre alguns dos vários direitos constitutivos, a maioria das respostas dadas pelas crianças revelava a ausência deles em sua vida cotidiana.

Perguntamos se elas estudavam, mas duas das respostas dadas indicaram uma defasagem no acesso ao direito à educação, visto que uma das crianças contou que seu irmão estava sem vaga, enquanto outra respondeu dizendo: “aqui eu estudo (referindo-se ao espaço da Associação)".

Na tentativa de abordar o direito à saúde, as questionamos também sobre a última vez que haviam ido ao médico, e a resposta, embora com um viés cômico, evidencia a adversidade presente na vida daqueles indivíduos: " $e u$ não fui nenhuma, só quando eu saí da minha mãe”.

Em relação à moradia, além de perguntarmos onde as crianças moravam, perguntamos também sobre com quem elas moravam. A minoria das crianças morava em casas com até quatro moradores, pois a maior parte delas tinha muitos irmãos(ãs), como se percebe na fala de duas meninas: "moro com meu padrasto, minha mãe e meus oito irmãos"; "moro com a minha irmã e nove irmãos”. 
Quando perguntadas sobre a rotina, algumas das crianças relataram que, além de arrumar a casa, em algum momento do dia cuidavam de algum irmão(ã) mais novo(a). O que não levaria à nenhuma implicação, torna-se motivo de questionamento ao alinharmos tais relatos com a idade de quem os relata. Sendo a média de idade dessas crianças igual a oito anos, abre-se um novo espaço para reflexão acerca dos direitos que deveriam ser-lhes assegurados, vide o art. $3^{\circ}$ do Código Civil, Lei $n^{\circ} 10.406$, de 10 de janeiro de 2002, ao elencar os menores de 16 anos como sendo absolutamente incapazes de exercer pessoalmente os atos da vida civil. Outrossim, há de se considerar o artigo 133 do Código Penal, Lei $n^{\circ} 2.848$, de 7 de dezembro de 1940, que, inclusive, prevê detenção para os casos de abandono de incapaz. Nota-se, portanto, uma realidade em que aquele considerado incapaz de permanecer em casa sozinho por longos períodos, além de permanecer, o cumpre com a incumbência de cuidar de outro menor.

Em um dos momentos em que a conversa havia desviado de seu foco principal, muito por conta da dispersão própria de crianças, tentamos retomar dizendo: “Vamos lá, outra coisa...”, mas houve uma interrupção por um comentário bastante significativo: "Lá vai ela falar da comida da escola...”. Aproveitando a oportunidade, questionamos se ela gostaria de falar sobre isso, e então a menina continuou: “É que no outro dia não teve comida lá na escola. Aí eles deram pizza pra gente!”. Perguntamos se ela havia gostado dessa troca, pois ao relatar aparentava dizer isso com insatisfação. No entanto, a resposta revela uma noção de que embora entenda que o correto seria a oferta do almoço, a oferta de pizza foi bem aceita, pois com repentino entusiasmo respondeu que sim, pois havia comido três pedaços.

Em relação ao grupo composto pelos adolescentes, durante a conversa surgiu o assunto de mídia social, uma vez que a internet e os aplicativos estão cada vez mais presentes na rotina desses jovens. (SPIZZIRRI et al., 2012) Tal como essas redes sociais solicitam de seus usuários uma apresentação de si mesmos, foi solicitado que os adolescentes se apresentassem, como se estivessem fazendo para tal fim. A pergunta disparadora foi para que eles falassem alguma coisa sobre si, dando liberdade para que falassem o que quisessem e achassem relevante, e assim sucedeu o diálogo:

Adolescente 1: 'Tenho 16 anos, gosto de desenhar, não gosto de praia porque acho suja, mas gosto de cachoeira. Moro em Jardim Gramacho...' 
Adolescente 2: 'Precisa falar que mora em Jardim Gramacho?', indagou o menino com ar risonho

Adolescente 1: 'Preciso! É um perfil'.

Adolescente 2: 'Eu colocaria Caxias, que é melhor'.

Nutricionista: 'Por que Caxias é melhor?'

Adolescente 2: 'Caxias é melhor, não tem poeira...'

Nesse instante, o adolescente 1 foi indagado se continuaria colocando que morava em Gramacho, e ele mesmo confirmou que sim, no entanto, prosseguiu com uma ressalva “Isso! Quer dizer, Gramacho não, Jardim Gramacho! De jardim não tem nada, mas é Jardim Gramacho. Duque de Caxias é a prefeitura e a prefeitura não presta, então... Eu prefiro Jardim Gramacho!”. E, então, foi perguntada a diferença entre Gramacho e Jardim Gramacho, o que incentivou a participação de um terceiro adolescente: "Eles vêm lá de Gramacho estudar aqui na nossa escola, que é melhor". No momento de apresentação da quarta adolescente, na etapa de falar sobre o lugar onde mora, a mesma, rindo, afirmou morar em Caxias.

Esse momento leva à reflexão sobre as questões do território e da significação do lugar para cada sujeito, e de como esses sujeitos possuem diferentes formas de fazer o mesmo território ser visto. Enquanto um reforça e exalta algumas questões desse lugar, onde Jardim Gramacho o representa e Caxias não, o outro prefere omitir e deixar vago o lugar que possa morar, pois se o especificar ficará claro as características vistas por ele como negativas da onde mora, enquanto Caxias ficaria amplo a ponto do imaginário do outro não conseguir definir as características do lugar. Assim, conseguimos perceber os diferentes significados dados a uma única palavra e, neste caso, também ao território. (SANTOS, 2007; FREIRE, 1994)

$\mathrm{Na}$ continuidade dessa ação, mas ainda abordando o tema de redes sociais, a resposta dada pelo participante direcionou o foco para a questão visual, das fotos que são inseridas nesse ambiente virtual. Nesse momento outro adolescente, que até então não havia participado da discussão, comentou que apenas tirava foto em casa, que era muito difícil tirar na rua, pois apesar de já ter 17 anos, ele não saia muito porque não tinha dinheiro. Disse também que se tivesse, viajaria para uns lugares diferentes, não ia ficar só em Jardim Gramacho e Caxias.

Quando perguntamos para qual lugar gostaria de ir, relatou que seu desejo era ir para o Centro do Rio de Janeiro, visitar "uma biblioteca enorme 
que tem lá” e que depois de visitar outros lugares no Rio de Janeiro, seu desejo era ir "para lugares fora".

E com essa fala percebemos o quanto alguns se sentem presos no seu território, prisão essa que mesmo sem grades os fazem sentir-se limitados, tornando a liberdade de escolha algo ainda utópico. Além disso, não passou despercebido os diferentes significados que o verbo viajar pode assumir, pois no momento que ouvimos, associamos o viajar com lugares mais longínquos, de modo que todo um contexto possa ser evidenciado através da simples escolha de uma palavra. Isso demonstra a importância do ouvir e de conhecer a realidade e as vivências daqueles que nos propomos a dialogar, de maneira que sem isso não alcançaremos êxito na partilha das experiências. Dessa maneira, talvez pela dificuldade de sair desse lugar, o centro do Rio e outros lugares no próprio estado do RJ se tornem tão distantes quanto aqueles aos quais imaginamos, evidenciando que o uso da palavra viajar se alinha ao sentido e significado que cada um lhe atribui.

\section{A MUdANÇA POSSÍVEL PERMEADA NA PRÁTICA}

No início de uma das atividades, cuja dinâmica foi organizada para que os participantes fossem divididos em grupos, uma das crianças, com cerca de oito anos, apesar de chegar atrasada e, por isso, ser colocada em um grupo previamente formado, reivindicou seu lugar. Chegou até nós e solicitou que fosse mudada de lugar, pois não gostaria de permanecer onde fora alocada. Nesse momento, de maneira cuidadosa, explicamos que não poderia mudar, pois havia chegado atrasada e os grupos já tinham sido definidos, ao passo que também propomos que ela chegasse mais cedo nas próximas semanas, de forma a estar presente no início das atividades. Em resposta, a criança fala o motivo do atraso: "estava cuidando do meu irmão, ele é doente", não como uma justificativa, mas relatando sua rotina.

Esse momento nos levou à reflexão sobre nossa prática, de modo, a perceber a necessidade do cuidado com as nossas atitudes, a importância da escuta e a real compreensão das rotinas e vivências do outro. Essas reflexões permeiam nossa prática e nos fazem constantemente avaliar nossa postura, adquirindo um cuidado maior. Assim, caminhamos para a permanente construção de uma perspectiva educadora por meio da reflexão crítica sobre a prática, pois é por meio da análise da experiência obtida com a prática 
realizada que se reúnem ferramentas que permitirão sua melhoria para a(na) próxima prática do que convencionamos denominar ação de educação alimentar e nutricional.

Nossas ações também reafirmam o reprodutivismo de que fala Bourdieu, pois a estrutura social com produção de pobreza e de abandono da população que mais necessita de alimentação saudável, está imbricada nas ações no campo de Alimentação e Nutrição. No entanto, embora haja um padrão difícil de mudar, há também uma necessidade de atuar criticamente no local, desenvolvendo estratégias criativas para o cotidiano. Estratégias pautadas na percepção do que somos e das razões que nos tornam agentes desse processo contínuo de construção social de nossos modos de comer, ou não.

\section{CONSIDERAÇÕES FINAIS}

Numa perspectiva crítica sobre as ações de educação alimentar e nutricional realizadas em ambientes de extrema pobreza nos questionamos sobre o potencial dessas práticas. Defendemos nessa discussão a função militante das políticas públicas globais dos Direitos Humanos e da Alimentação Saudável como um resgate de princípios humanos e de uma vida saudável em comum, mas que demanda uma adaptação na prática. A prática representa o espaço social das mediações de afetos e negociações de saberes, atribuir sentidos é uma capacidade e uma necessidade do homem que faz parte do universo simbólico e das relações sociais construídas nas práticas. Assim situamos nossa questão, "Como podemos compreender as condições de saúde na prática quando não se compreende os anseios e sentidos da vida cotidiana de crianças e adolescentes de Jardim Gramacho?”

Modelos prescritivos, construídos de modo unilateral hegemônico, produzem violência simbólica e reafirmam "podres poderes" que se renovam e multiplicam em novos arranjos estruturados e estruturantes nas relações sociais e, portanto, de alimentação por desdobramento. $\mathrm{O}$ ir e vir ao campo, por meio da extensão, permite um repensar contínuo sobre as relações sociais extramuros da universidade permitindo um aprofundamento teórico na pesquisa científica do campo da Alimentação e Nutrição numa abordagem das ciências humanas.

As possibilidades de transformar um ambiente de extrema pobreza, como o de Jardim Gramacho, demanda a construção de novos sentidos e significados, 
calcados nas ações concretas dos praticantes. Alimentação saudável como estratégia global é uma dimensão de macrocosmo, um motor militante para promover negociações na cultura local. A resposta para nossa pergunta esteve na dimensão do microcosmo, no contexto social de cada prática, em cada momento, onde as ações educativas em alimentação puderam operar como "respiradouros” numa realidade sufocante de desigualdades.

\section{REFERÊNCIAS}

BAMBERG, M.; GEORGAKOPOULOU, A. Small stories as a new perspective in narrative and identity analysis. Text and Talk, Berlin, v. 28, n. 3, p. 377-396, 2008.

BASTOS, L. C.; BIAR, L. A. Análise de narrativa e práticas de entendimento da vida social. Delta: documentação de estudos em linguística teórica e aplicada, São Paulo, v. 31, p. 97-126, 2015. Número Especial. Disponível em: https://dx.doi. org/10.1590/0102-445083363903760077. Acesso em: 9 out 2019.

BECKER, H. S. Métodos de pesquisa em ciências sociais. São Paulo: Hucitec, 1994.

BOURDIEU, P. A distinção: crítica social do julgamento. São Paulo: Edusp, 2007.

BOURDIEU, P. A reprodução: elementos para uma teoria do sistema de ensino. 7. ed. Petrópolis: Vozes, 2014.

BRASIL. Lei $n^{\circ} 2.848$, de 7 de Dezembro de 1940. Código Penal. Diário Oficial da União: seção 1, Brasília, DF, 8 dez. 1940. Disponível em: https://www.planalto.gov. br/ccivil_03/Decreto-Lei/Del2848.htm. Acesso em: 11 jan. 2020.

BRASIL. Lei ${ }^{\circ}$ 8.069, de 13 de julho de 1990. Dispõe sobre o Estatuto da Criança e do Adolescente e dá outras providências. Diário Oficial da União: seção 1, Brasília, DF, 13 jul. 1990. Disponível em: http://www.planalto.gov.br/ccivil_03/LEIS/L8069. htm\#art266. Acesso em: 11 jan. 2020.

BRASIL. Lei $n^{\circ} 10.406$, de 10 de janeiro de 2002. Institui o Código Civil. Diário Oficial da União: seção 1, Brasília, DF, 11 jan. 2002. Disponível em: http://www. planalto.gov.br/ccivil_03/leis/2002/L10406compilada.htm. Acesso em 11 jan. 2020.

BRASIL. Ministério da Saúde. Guia alimentar para a população brasileira. Brasília, DF: Ministério da Saúde, 2014. Disponível em: https://bvsms.saude.gov.br/bvs/ publicacoes/guia_alimentar_populacao_brasileira_2ed.pdf. Acesso em: 15 jan. 2020.

CAREGNATO, C. E.; PINHO, P. M. Observar e promover a diversidade a partir da escola. In: CAREGNATO, C. E.; BOMBASSATO, L. C. (org.). Diversidade Cultural: viver diferenças e enfrentar desigualdades na Educação. Erechim: Gráfica e Editora Ideal, 2013, v. 1, p. 189-202.

D’AMBROSIO, U. Etnomatemática: elo entre as tradições e a modernidade. 2. ed. Belo Horizonte: Autêntica, 2005. 
DIEZ-GARCIA, R.W.; CASTRO, I. R. R. A culinária como objeto de estudo e de intervenção no campo da alimentação e nutrição. Ciência \& Saúde Coletiva, Rio de Janeiro, v. 16, n. 1, p. 91-98, 2011.

FOUCAULT, M. Vigiar e punir: nascimento da prisão. Petrópolis: Vozes, 2013.

FREIRE, P. Educação como prática da liberdade. Rio de Janeiro: Paz e Terra, 1999.

FREIRE, P. Pedagogia da autonomia. São Paulo: Paz e Terra, 2011.

FREIRE, P. Pedagogia do oprimido. Rio de Janeiro: Paz e Terra, 1994.

FREIRE, P. Pedagogia dos sonhos possíveis. São Paulo: Paz e Terra, 2014.

GRENFELL, M. Pierre Bourdieu: conceitos fundamentais. 41. ed. Petrópolis: Vozes, 2018.

INSTITUTO BRASILEIRO DE ANÁLISES SOCIAIS E ECONÔMICAS. Diagnóstico Social. Duque de Caxias, 2005.

LABOV, W. The transformation of experience in narrative syntax. In: LABOV, W. Language in the inner city. Philadelphia: University of Pennsylvania Press, 1972. p. 354-392.

LINDE, C. Life stories: the creation of coherence. New York: Oxford University Press, 1993.

MENEZES, M. F. G.; MALDONADO, L. A. Do nutricionismo à comida: a culinária como estratégia metodológica de educação alimentar e nutricional. Revista Hospital Universitário Pedro Ernesto, Rio de Janeiro, v. 14, n. 3, p. 82-90, 2015. Disponível em: https://doi.org/10.12957/rhupe.2015.19950. Acesso em: 10 out 2019.

PAIVA, J. B.; MAGALHÃES, L. M.; SANTOS, S. M. C. et al. A confluência entre o "adequado" e o "saudável": análise da instituição da noção de alimentação adequada e saudável nas políticas públicas do Brasil. Caderno de Saúde Pública, Rio de Janeiro, v. 35, n. 8, p. 1-12, 2018.

PINTO, V. L. X.; ARAÚJO, M. F.; SOUZA, A. C. F. Comer, pensar e sentir: uma experiência de educação alimentar e nutricional na educação infantil. In: FREITAS, M. C. S.; FONTES, G. V.; RAMOS, L. B. et al. Narrativas sobre cuidado alimentar e o comer na escola. Salvador: Edufba, 2016. p. 69-88.

RIESSMAN, C. K. Narrative analysis. Newbury Park: Sage, 1993.

SANTOS, L. A. S. Educação alimentar e nutricional no contexto da promoção de práticas alimentares saudáveis. Revista de Nutrição, Campinas, v. 18, n. 5, p. 681-692, 2005.

SANTOS, M. Território, territórios: ensaios sobre o ordenamento territorial.

Rio de Janeiro: Lamparina, 2007. 
SILVA, J. K.; PRADO, S. D.; CARVALHO, M. C. V. S. et al. Alimentação e cultura como campo científico no Brasil. Physis: revista de saúde coletiva, Rio de Janeiro, v. 20, n. 2, p. 413-442, 2010.

SOUZA, E. C.; LIMA, A. N.; ALMEIDA, M. N. Alimentação, aprendizagem e cultura escolar: com fome ninguém aprende. In: FREITAS, M. C. S.; FONTES, G. V.;

RAMOS, L. B. et al. Narrativas sobre cuidado alimentar e o comer na escola. Salvador: Edufba, 2016. p. 139-152.

SPIZZIRRI, R. C. P.; WAGNER, A.; MOSMANN, C. P. et al. Adolescência conectada: mapeando o uso da internet em jovens internautas. Psicologia Argumento, Rio de Janeiro, v. 30, n. 69, p. 327-335, 2012. Disponível em: http://www2.pucpr.br/reol/ index.php/pa?ddl=5979\&dd99=view>. Acesso em: 10 out 2019. 



\section{CARIDADE PARA OS MERECEDORES E SALVAÇÃO PARA OS DOADORES SENTIDOS DA COMIDA DISTRIBUÍDA PARA A POPULAÇÃO EM SITUAÇÃO DE RUA ${ }^{1}$}

JULIA HORTA NASSER

SHIRLEY DONIZETE PRADO

FRANCISCO ROMÃO FERREIRA

DANIELA MENEZES NEIVA BARCELLOS

\section{SÃo MUITOS OS INTERESSES, VALORES E SENTIDOS DEPOSITADOS NA COMIDA QUE É SERVIDA “DE GRAÇA”}

Ao transitar a noite pelo centro da cidade do Rio de Janeiro, observa-se um grande número de instituições e organizações, religiosas ou não, distribuindo comida e roupas para as pessoas que se encontram em situação de rua e habitam aquele local. Na maioria das vezes, o alimento ali distribuído corresponde a única refeição que aquelas pessoas fazem no dia.

1 Texto desenvolvido a partir da dissertação de mestrado acadêmico intitulada O que comem os excluídos? Os diferentes sentidos da comida oferecida para a população em situação de rua defendida no ano de 2018, no Programa de Pós-Graduação em Alimentação, Nutrição e Saúde da Universidade do Estado do Rio de Janeiro (UERJ). O presente trabalho foi realizado com o apoio da Coordenação de Aperfeiçoamento de Pessoal de Nível Superior (Capes) - Código de Financiamento 001. 
É interessante notar que as diversas instituições que fazem esse tipo de trabalho lidam de formas diferentes com a questão da alimentação: algumas só oferecem a comida e não estabelecem contato algum com o assistido; outras oferecem a comida junto aos serviços, em ações sociais; há as que condicionam a doação da comida à participação dessas pessoas a algum culto religioso ou oração na rua; há, ainda, as que oferecem a comida juntamente com yoga e meditação; entre outras possibilidades. A forma como cada uma dessas instituições e organizações vê a população em situação de rua e entende esse processo está relacionada com os sentidos atribuídos à comida oferecida a essas pessoas.

Buscando compreender as redes de sentido em torno das práticas de distribuição de comida para a população em situação de rua consideramos, neste ensaio, um conjunto bibliográfico, com destaque para abordagens etnográficas, além de documentos institucionais, páginas na internet e reportagens sobre a temática em questão. (NASSER, 2018)

O presente estudo está inscrito no campo científico da Alimentação e Nutrição. Entendemos campo no sentido atribuído por Pierre Bourdieu (1989), para quem existe uma espécie de poder simbólico que organiza as práticas e os discursos, cria formas de entendimento da realidade e dá sentido ao real.

Ao abordar a alimentação de pessoas em situação de rua colocamo-nos na interface da produção de saberes situada entre o estilo biomédico de pensar e as Humanidades. Em outras palavras, trata-se de uma opção que implica em delicada tensão entre campos científicos que fazem parte de uma rede ou um conjunto de relações objetivas definidas a partir das diferentes posições que os atores - sujeitos, agentes ou instituições - ocupam na atual estrutura da distribuição das diferentes espécies de poder - ou de capital.

O capital hoje, inerente aos estudos de cunho biomédico, traduz-se em uma posição hierárquica que busca a dominação em relação aos outros atores que participam do mesmo jogo. Contudo, o campo é concebido em seu dinamismo; ele é mutável. Refletindo a dinâmica das posições e das relações de poder próprias a cada campo coloca, simultaneamente, a recusa à subordinação, à dependência, à homologia. Expressando hierarquias que são estruturadas e ao mesmo tempo estruturantes das ações e que definem as relações no campo, o poder faz-se presente, toma forma no jogo, materializa-se também neste investimento situado no âmbito qualitativo da 
compreensão das redes de sentido em torno das práticas de distribuição de comida para a população em situação de rua. Poder que possibilita registrar a distribuição de comida, para além dos aspectos nutricionais, entendida como capital em jogo hirto, retesado, tanto para quem recebe, quanto para quem doa, uma vez que essa doação transforma-se em moeda simbólica nas trocas subjetivas do campo social.

Isso porque a comida faz do alimento algo além de veículo. Possui a função objetiva de carregar os nutrientes e que está situado na ordem da natureza, no plano biológico ou bioquímico; a comida é o alimento simbolizado que está na ordem da cultura. Nessa diferenciação conceitual, quando comemos, incorporamos tanto elementos biológicos quanto os aspectos culturais daquilo que ingerimos. Dentro dessa perspectiva, comer é mais que um ato de sobrevivência, é uma prática simbólica e cultural. Então, oferecer comida à população em situação de rua não é apenas um gesto para saciar a fome biológica.

Doar comida e comer essa comida corresponde a uma ação que pode ter outras implicações além daquelas da esfera nutricional, pois quem capitaliza nesse jogo não são apenas os moradores de rua: demais atores sociais e instituições também se alimentam dos benefícios, dos sentidos gerados pelas doações. (CARVALHO; LUZ; PRADO, 2011; CONTRERAS; GRACIA, 2011; SILVA et al., 2010) Afinal, de acordo com Max Weber (2010), toda ação possui um sentido. Como toda conduta humana - fazer externo ou interno, permissão ou omissão -, é dotada de um significado subjetivo por quem a executa e a orienta; sendo direcionada por um outro, Weber a denomina de ação social. Ao compreender uma ação social, captamos e interpretamos sua conexão de sentidos.

Entendemos, então, a distribuição de comida como uma relação social, pois a conduta de cada qual entre os múltiplos agentes envolvidos orienta-se por um conteúdo de sentido reciprocamente compartilhado. Se para receber comida é preciso, por exemplo, atender a alguma exigência, partilha-se essa exigência entre quem doa e quem recebe, havendo que se investir para conhecer os significados atribuídos a essas ações sociais pelos atores envolvidos. Na relação social, o conteúdo de sentido é incorporado pelos agentes como uma regra orientadora da sua conduta na medida em que é aceito como legítimo, tornando-se um sentido aceito e que assume a forma de validação de uma ordem legítima. (WEBER, 1977) 
Assim, o ato de comer e a ação de distribuir comida, por ser uma ação social possui um significado e um sentido compartilhado pelos atores sociais que participam do jogo, de forma consciente ou não. Esse sentido é produzido socialmente a partir das lógicas que regem o modo de organização social e das relações de poder-saber ali estabelecidas. Quando comemos, ingerimos também essas lógicas. Lógicas essas que também produzem identidades individuais e coletivas, subjetividades e a forma como esses sujeitos estabelecem relações sociais.

Mas a apropriação dos sentidos não se dá apenas no plano das relações entre sujeitos e coletividades que estão na rua; os sentidos são também apropriados, reproduzidos e ressignificados por instâncias institucionais que reafirmam suas práticas e criam estratégias de ação voltadas para os seus interesses. O capital simbólico oriundo da doação de comida extrapola a sua função local e gera ganhos em outras esferas no campo da política partidarizada, nas formas de atuação das políticas públicas, em esferas de atuação religiosa e nas ações de marketing social das empresas que participam indiretamente das ações. São muitos os interesses (políticos e econômicos), valores (religiosos e morais) e sentidos (do jogo simbólico da cultura) depositados na comida que é servida "de graça”.

\section{A PRODUÇÃO DE SENTIDOS E SUBJETIVIDADES EMTEMPOS DE EXCLUSÃO}

O contexto da existência em situação de rua nos convida a compreender os modos de operação das lógicas que constroem a realidade em uma dada sociedade, a produção dos sentidos atribuídos às ações e as subjetividades presentes no campo em estudo. Os conceitos de produção de subjetividade, de Guattari e Rolnik (2013), e de processos de subjetivação, de Foucault (2004a), nos permitem avanços consideráveis em relação a este tema.

Guattari e Rolnik (2013) definem subjetividade, ${ }^{2}$ como um fluxo contínuo de sensações, modos de existir, de imagens, sons, afetos, valores, etc. A subjetividade é fabricada e modelada no registro social, ou seja, no entrecruzamento de instâncias sociais, técnicas, institucionais e individuais - a partir de

2 Guattari e Rolnik (2013) preferem se utilizar do termo subjetividade ao invés do termo sujeito, para ressaltar o caráter dinâmico que eles querem imprimir ao conceito. 
máquinas que forjam maneiras de ser, estar e viver. Essas máquinas produzem a maneira que o indivíduo "[...] percebe o mundo, de se articular com o tecido urbano, com os processos maquínicos do trabalho, e com a ordem social suporte dessas forças produtivas” (GUATTARI; ROLNIK, 2013, p. 34) e variam em função ao modelo de organização de uma sociedade.

As lógicas que regem uma dada sociedade produzem as subjetividades ali presentes. Quando esses modelos de organização seguem lógicas normatizantes e serializantes, dizemos que as subjetividades ali produzidas são assujeitadas, são esquadrinhadas, ou seja, encaixadas em maneiras preexistentes de ser. (BAREMBLIT, 1994; GUATTARI; ROLNIK, 2013) Os movimentos que esquadrinham, bloqueiam os processos de produção de subjetivação "[...] não assujeitada, primigênica, produtiva, revolucionária, em que o desejo se realiza em conexões locais, micro e se efetua gerando o novo”. (BAREMBLIT, 1994, p. 51) Podemos observar que duas lógicas principais regem os processos de produção de subjetividade, as lógicas normatizadoras, maquínicas, que esquadriam as subjetividades na tentativa de adequá-las às subjetividades existentes; e lógicas singularizantes, que produzem subjetividades a partir dos processos criativos de produção.

Sobre os processos de subjetivação, segundo Foucault (2004a), os sujeitos são formados a partir das relações de poder-saber em uma dada sociedade. Definimos Saber, dentro de uma perspectiva foucaultiana, como um conjunto de elementos - objetos, tipos de formulação, conceitos e escolhas teóricas - formado a partir de uma única e mesma positividade, no campo de uma formação discursiva. Já em relação ao conceito de poder, Foucault (1989) se opõe a noção de um poder de submissão maciço e homogêneo de um indivíduo, classes, grupos, sobre outros, que pode ser dividido entre aqueles que o possuem e o detêm exclusivamente e aqueles que são submetidos a ele, tal qual descrito no poder-soberano - uma das formas de se exercer o poder. Para o autor, o poder é circulante, funciona em cadeia, se exercendo em rede. Na sua teia, os indivíduos circulam podendo num determinado momento exercer o poder e no outro sofrer a sua ação. Foucault (1988) discute em suas obras sobre o poder como um conjunto de relação, “relações de poder”. Sobre isso, nos diz:

[...] o poder não é algo que se adquire, arrebate ou compartilhe, algo que se guarde ou deixe escapar; o poder se exerce a partir 
de inúmeros pontos e em meio a relações desiguais e móveis; as relações de poder não se encontram em posição de exterioridade com respeito a outros tipos de relações - processos econômicos, relações de conhecimento, relações sexuais -, mas lhe são imanentes a estes; elas são os efeitos imediatos das divisões, desigualdades e desequilíbrios que ocorrem nestes outros tipos e, inversamente, são as condições internas dessas diferenciações; as relações de poder, não estão em posição superestruturais, tendo meramente um papel de proibição ou acompanhamento; elas têm um papel produtivo, onde quer que entre em ação; o poder vem de baixo; isto é, não há, no princípio das relações de poder, e como matriz geral, uma oposição binária e global entre os dominadores e os dominados, dualidade que repercute de alto a baixo e sobre grupos cada vez mais restritos até as profundezas do corpo social [...]; as relações de poder são, ao mesmo tempo, intencionais e não subjetivas. Se, de fato, são inteligíveis, não é porque sejam efeito, em termos de causalidade, mas porque atravessadas de fora a fora por um cálculo: não há poder que se exerça sem uma série de miras e objetivos. Mas isso não quer dizer que resulte da escolha ou da decisão de um sujeito, individualmente [...]. (FOUCAULT, 1988, p. 104-105)

Voltando aos processos de subjetivação, a maneira de ser e estar em sociedade é construída num processo diretamente relacionado com os saberes próprios daquele contexto histórico-cultural que por sua vez respondem por relações de poder em curso. Quando os conhecimentos sobre determinados assuntos vão sendo produzidos, juntamente com eles vão sendo gerados sujeitos. (FOUCAULT, 2004a; OKSALA, 2011)

O conceito de governamentalidade de Foucault também é importante para a discussão aqui proposta. $\mathrm{O}$ autor utiliza esse termo para se referir ao estudo da maneira de se governar. Foucault traz duas ideias principais para a noção de governamentalidade. A primeira está relacionada a governamentalidade política, que é formada por racionalidades, instrumentos técnicos - dispositivos de segurança, tecnologia político-militar e poder de polícia - e formas de instrumentalização do Estado para o governo dos corpos. A segunda noção refere-se ao encontro das técnicas de dominação e controle e o governo de si. Dentro dessa perspectiva o poder emana através do Estado, tal qual escrita na governamentalidade política, mas se espraia, dissemina, pela vida social, criando mecanismos de regulamentação 
da população. (FOUCAULT, 2012) Segundo Foucault(2012, p. 283), “[...] a soberania não se exerce sobre as coisas, ela se exerce primeiro sobre um território, e, por conseguinte, sobre os sujeitos que nele habitam".

Nessa perspectiva, não se trata apenas de controlar o território e as relações políticas e econômicas, mas, principalmente, governar os corpos, corações e mentes, disciplinar os corpos a partir de um controle disciplinar e um conjunto de regras, valores e sentidos que mantenham a governamentalidade. Para demonstrar essas diferentes formas de governar os corpos e o governo de si, Foucault lança mão do que ele chama de tecnologia de poder. $\mathrm{O}$ autor, na sua obra, apresenta três tecnologias de poder: soberano, disciplinar e a biopolítica. Apesar dessas três tecnologias de poder emergirem em momentos distintos da história da humanidade, o surgimento de uma não exclui e nem suprime a anterior, nem suas técnicas, ela a integra e a modifica. $\mathrm{O}$ preconceito generalizado com a população em situação de rua atualiza e naturaliza uma posição política que produz normas disciplinares as quais enquadram os corpos da população de rua e um olhar médico que tenta higienizar, promover uma espécie de eugenia ao tentar retirar os corpos considerados sujos, indesejáveis, perigosos e nocivos ao bem-estar do conjunto da sociedade. Mas, não podemos esquecer que são corpos os quais nos apresentam as consequências da desigualdade social, da exploração econômica e da exclusão do mundo do trabalho.

A retirada dessa população, majoritariamente negra, dos lugares de grande circulação de turistas na cidade nos períodos dos grandes eventos recentes - Rio+20, Copa do Mundo, Olimpíadas etc. - é um exemplo dessa convergência entre segurança pública, saberes médicos, higienização dos corpos, estratégias de controle disciplinar, normatização da população e regulamentação do uso do espaço público. Tudo em nome da higiene, da segurança, da saúde e do controle do Estado sobre a população pobre. Os saberes médicos assumem então um papel fundamental nessa limpeza social, nessa higienização dos corpos indisciplinados ou não adaptados ao sistema produtivo que ameaçam a segurança do conjunto da sociedade e não obedecem às normas vigentes, pois o conjunto constituído por medicina, segurança pública e higiene apresentam

[...] o vínculo que se estabelece entre as influências científicas sobre os processos biológicos e orgânicos (isto é, sobre a popu- 
lação e sobre o corpo) e, ao mesmo tempo, na medida em que a medicina vai ser uma técnica política de intervenção, com efeitos de poder próprios. A medicina é um poder-saber que incide ao mesmo tempo sobre o corpo e sobre a população, sobre o organismo e sobre os processos biológicos e que vai, portanto, ter efeitos disciplinares e efeitos regulamentadores. (FOUCAULT, 2002, p. 302)

O poder soberano, a sociedade da soberania tem como um dos seus atributos fundamentais o direito de vida ou morte, ou seja, o direito de fazer morrer ou deixar viver. O exercício de poder girava em torno do Rei ou príncipe, o soberano, sobre seus súditos. Todo crime era percebido como ataque à própria pessoa do soberano. $\mathrm{O}$ castigo era sempre mais brutal que o crime e servia como exemplo a não ser seguido aos demais. O ápice do exercício do poder soberano se dava no suplício, ou seja, castigos físicos sobre o corpo do condenado.(FOUCAULT, 2002, 2008) A morte do outro, daquele que é considerado indigno, improdutivo ou incapaz de gerir a própria vida torna-se então "natural", fazendo com o que os preconceitos de raça, de classe ou de etnia se afirmem e justifiquem a "limpeza social", ao eliminar da vista, ou da vida, os seres que são considerados indesejáveis ou perigosos. Segundo Foucault (2002, p. 309), o racismo

[...] assegura a função de morte na economia do biopoder, segundo o princípio de que a morte dos outros é o fortalecimento biológico da própria pessoa na medida em que ela é membro de uma raça ou uma população unitária e viva. [...] A especificidade do racismo moderno, o que faz sua especificidade, não está ligada a mentalidades, a ideologias, a mentiras do poder. Está ligada à técnica do poder, à tecnologia do poder. [...] Portanto, o racismo está ligado ao funcionamento de um Estado que é obrigado a utilizar a raça para exercer o seu poder, a eliminação das raças e a purificação da raça para exercer o seu poder soberano.

A segunda tecnologia de poder descrita por Foucault é o poder disciplinar/sociedade disciplinar. Seu principal dispositivo é a disciplina e seu principal foco é tornar os corpos dóceis e úteis para o trabalho. As disciplinas são um conjunto de procedimentos, técnicas, estratégias, que têm o corpo como alvo de seu exercício, da sua política de correção. (FOUCAULT, 2008) 
Nessa perspectiva, o poder disciplinar não aceita uma população empobrecida, que não gera riqueza, que atrapalha o bom funcionamento da ordem pública, que não segue as normas de higiene e conduta ditas "normais". E o corpo que não segue suas lógicas não tem seus direitos respeitados. O poder disciplinar, portanto, segrega, exclui e dificulta a circulação dos corpos considerados indisciplinados.

A terceira e última tecnologia de poder descrita por Foucault é a biopolítica. A biopolítica se dirige não ao homem corpo e, sim, ao homem ser vivo, ou seja, a massa global, a população. Tem como foco "fazer viver e deixar morrer”. (FOUCAULT, 2002, p. 202) A biopolítica é um conjunto de processos que lidam com as práticas regulatórias dos fenômenos que são coletivos. O poder disciplinar está relacionado à acomodação de mecanismos de poder sobre os corpos individuais, como a vigilância e o treinamento, dentro de um conjunto de técnicas chamada de disciplina. Já a biopolítica está relacionada ao conjunto de processos que produzem mecanismos regulatórios. O poder aqui não é o da lei, e sim da norma. Norma essa que não vai apenas reprimir os sujeitos, mas o constituir, tal qual explicado anteriormente nos processos de subjetivação. O corpo precisa ser disciplinado e a população precisa ser regulada. Por fim, dá-se o nome de biopoder a junção do poder disciplinar e da biopolítica.

É importante ressaltar que os mecanismos da biopolítica são muito mais sutis que os mecanismos de poder do poder disciplinar. Aqui as práticas regulatórias são internalizadas por cada sujeito, no que o autor chama de governo de si, ou técnicas de cuidado de si. A população, a sociedade, não precisa de um objeto concreto, tal qual o panóptico, que lembre o que devemos ou não fazer. É a partir da internalização das normas, leis, saberes, controles das estratégias que, em liberdade, relacionamo-nos com os outros e cada um de nós consigo mesmo. É dentro dessa perspectiva que Foucault afirma que podemos analisar as técnicas de governos dos outros, ao analisar as técnicas de governo de si. (REVEL, 2011)

Como veremos a seguir, o sujeito que vive sua trajetória de vida nas ruas, constrói sua forma de ser e estar no mundo, numa lógica diferente das lógicas ditas “normais” em nossa sociedade. E muitas das ações de distribuição de comida para a população em situação de rua tentam adequar esse grupo populacional a essas tais lógicas normatizantes e serializantes, produzindo assim subjetividades assujeitadas, nessa tentativa de transformá-los 
em corpos dóceis e úteis para o trabalho. Mas antes de entrar nessa seara, apresentaremos a população em situação de rua, grupo foco dessas ações.

\section{OS EXCLUÍDOS: POPULAÇÃO EM SITUAÇÃO DE RUA}

Quando andamos pela cidade, no corre-corre da vida, quase não percebemos população em situação de rua. Na maioria das vezes, misturam-se na paisagem das grandes cidades. Notamos sua presença quando, de alguma forma, nos incomodam, seja pela sujeira, pelo odor que emitem, por um pedido impertinente, pelo medo, pela compaixão, mas, de uma forma geral, não observamos a sua presença. "Mendigos”, “loucos”, ““alcoólatras”, “"vagabundos”, “ladrões”, ““sujos”, ““cracudos”, “"perigosos”, ““coitados”, muitos são os adjetivos atribuídos para as pessoas que vivem parte de suas trajetórias de vida nas ruas. Eles ficam como que invisibilizados do jogo social por não participarem do mercado, do mundo produtivo do trabalho e dos códigos sociais padronizados e legitimados pela cultura hegemônica.

Podemos definir população em situação de rua como grupo social heterogêneo, sujeitos com laços familiares e comunitários fragilizados ou rompidos e que, por não terem moradia e, na maioria dos casos, nem emprego formal, utilizam a rua, albergues e abrigos como local de moradia de forma provisória ou permanente. Estamos tratando de um fenômeno social complexo, que tem a exclusão social e econômica como principal fator de produção, reprodução e agravamento dessa situação. (BOVE; FIGUEIREDO, 2014)

O fenômeno social "população em situação de rua” é antigo, acentuado em face das transformações sociais e econômicas decorrentes do advento das sociedades pré-industriais da Europa, do capitalismo industrial e o fortalecimento dos grandes centros urbanos que culminaram na Revolução Industrial e Agrícola na segunda metade do século XVIII. No Brasil, o fenômeno surge desde antes do Império, com as constantes migrações das regiões norte e nordeste para os municípios mais desenvolvidos. A abolição da escravatura também foi um importante marco para o aumento de pessoas em situação de rua. Em nosso país, a população de rua tem cor e ela é majoritariamente negra. (BOVE; FIGUEIREDO, 2014)

São inúmeros os motivos que levam as pessoas a viver parte da suas trajetórias de vidas nas ruas e isso produz umas das principais marcas desse segmento populacional: a heterogeneidade. Atualmente, o termo técnico 
usado para designar esse grupo populacional é “população em situação de rua”. Estar em situação de rua não significa vivenciar uma situação estática e linear; são grupos que transitam, trabalham e moram na rua por diversos motivos. A rua, em diferentes graus, ocupa um lugar de referência e um papel central em suas vidas. (NAIFF, 2016)

Outra característica marcante desse grupo populacional é a exclusão social. Esta exclusão social pode ser entendida como um fenômeno dinâmico com múltiplas dimensões: a vulnerabilidade nos vínculos no mundo do trabalho, nas dimensões sociofamiliar, política e humana - esta última que se caracteriza pela fragmentação dos laços entre os indivíduos, a sociedade e o Estado, na intensa privação material e na desqualificação desse sujeito enquanto humano e cidadão. Em geral, no senso comum, essas pessoas são vistas, cotidianamente, como algo que as aproxima da animalidade, colocando-as numa condição que as distancia das características que traduzem sua humanidade, gerando preconceito, essa marca social que as inferioriza. Isso sem que se procure saber o mínimo que seja sobre as causas deste processo, as circunstâncias reais e as alternativas possíveis para solucionar o problema. O preconceito afasta e, muitas vezes, não permite sequer uma aproximação em caráter de ajuda humanitária.

Os processos relacionados à vulnerabilidade dos vínculos no mundo do trabalho são importantes para a produção da exclusão social. Essa fragilidade é induzida pelo modo de organização da sociedade capitalista, sendo um dos fatores principais de produção de "desnecessários humanos”, conforme conceito trabalhado por Bauman (2005). A dimensão sociofamiliar se caracteriza pelo distanciamento dos valores e das relações familiares e comunitárias, devido a alguma precariedade ou ruptura desses vínculos. Os elos sociais estabelecidos com a família e a comunidade, segundo Escorel (1999), tornam-se algumas das principais referências de reconhecimento de pertencimento e suporte frente às adversidades provenientes do mercado de trabalho e das inconsistências de políticas sociais. A exclusão ou, como diz a autora, a desvinculação no âmbito sociofamiliar, produz solidão e isolamento (parcial ou completo) e acarreta o não compartilhamento de um lugar social, devido à inexistência de ancoragem em uma unidade de pertencimento familiar ou comunitária. (ESCOREL, 1999)

A dimensão política da exclusão social está ligada à relação entre a pobreza e as situações de não exercício da cidadania. A cidadania constitui-se 
no direito de termos direito e o cidadão é aquele portador do direito legítimo, isto é, são sujeitos que possuem o poder de agir e falar e de serem ouvidos. O sujeito pode ser privado do direito a ser cidadão de algumas formas: no despotismo, no qual uma única pessoa tem direito; no caso de estrangeiros que vivem sob leis diferenciadas; nas situações sociais em que não há leis para determinado grupo populacional; e nas condições em que, embora haja leis para todos, o exercício do direito é dado a determinados grupos. O último caso está relacionado com a dimensão política da exclusão. (ARENDT, 1989; ESCOREL, 1999; WOLLZ et al., 2015)

Por fim, a dimensão humana da exclusão social que, de acordo com Escorel (1999, p. 81) "[...] pode atingir o seu limite, o limiar da existência humana” e que está relacionada com a redução desses grupos sociais excluídos à condição de labor. Em Hanna Arendt (2007), a condição humana, ela chama de vita activa, está relacionada a três atividades humanas fundamentais: labor, trabalho e ação. O labor corresponde aos processos biológicos, ao metabolismo e a satisfação das necessidades básicas, que nos mantém vivos, e que assegura a sobrevivência da espécie. O trabalho está associado à capacidade humana de produzir e fabricar o mundo que vivemos. Já a ação está relacionada com a habilidade dos homens interagirem; é o que nos dá a capacidade da construção das diferenças, da pluralidade. Enfim, o que nos dá a condição humana, para a autora, são essas três atividades fundamentais. $\mathrm{Na}$ exclusão social ocorre uma redução da atividade humana a condições de labor. Como efeito a ação humana passa a ser direcionada a manutenção das necessidades básica fundamentais, ou seja, a manutenção da vida biológica. (ARENDT, 2007; ESCOREL, 1999)

É nesses termos que tomamos as dimensões aqui citadas como produtoras desse fenômeno chamado exclusão social. Os grupos excluídos são, portanto, aqueles que, sem vínculo com o mundo do trabalho, sem possibilidade de exercer seus direitos, ou seja, cidadania, e cujos laços familiares e comunitários estão fragilizados ou rompidos, têm sua ação no mundo limitada à sua capacidade de sobrevivência. A esses classificamos como desnecessários, refugo, supérfluo à vida social. Sobre isso diz Escorel (1999, p. 81, grifo do autor):

A exclusão social pode se caracterizar não só pela extrema privação material, mas, principalmente, porque essa mesma privação material 'desqualifica' seu portador, no sentido de que lhe retira 
a qualidade de cidadão, de brasileiro (nacional), de sujeito e de ser humano, de portador, vontades e interesses legítimos que o identificam e diferenciam. A exclusão social significa o não encontrar nenhum lugar social, o não pertencimento a nenhum topos social, uma existência limitada à sobrevivência singular e diária. Mas ao mesmo tempo, o indivíduo mantém-se prisioneiro do próprio corpo. Não (mais) um lugar social para ele, mas ele deve encontrar formas de suprir suas necessidades vitais e sobreviver sem suporte estáveis materiais e simbólicos. A ausência de lugar envolve uma 'anulação' social, uma diferença desumanizadora, que reveste seu cotidiano com um misto de indiferença e hostilidade.

Uma outra marca importante da população em situação de rua são os estigmas que lhes são atribuídos em função de sua trajetória de vida, esses predicados que tornam o indivíduo diferente dos outros, reduzindo-o a uma pessoa diminuída ou estragada. A sociedade categoriza seus membros como comuns, naturais, normais e anormais de acordo com seus ambientes sociais, ou seja, suas rotinas e relações sociais, criando assim identidades sociais. (GOFFMAN, 1978)

Essas identidades sociais (reais ou virtuais), características e atributos individuais, são preconcepções construídas nos ambientes sociais transformadas em expectativas normativas, ou seja, em exigências apresentadas ao sujeito de modo rigoroso, afirmando aquilo que deveria ser. A condição necessária para a vida social é que todos os participantes compartilham um único conjunto de expectativas normativas. As normas precisam ser incorporadas por aqueles que compõe o grupo. Quando uma regra é quebrada surgem medidas restauradoras, seja por agências de controle, seja pelo próprio indivíduo. De uma forma geral, é destoante qualquer membro de um determinado grupo que não adira a norma, essas que engendram desvios e conformidades. São, então, desviantes sociais esses que não se comportam em conformidade com as normas tidas como legítimas.

O estigma envolve não tanto um conjunto de indivíduos concretos que podem ser divididos em duas pilhas, a de estigmatizados e a de normais, quanto um processo social de dois papéis no qual cada indivíduo participa de ambos, pelo menos em algumas conexões $e$ em algumas fases da vida. O normal e o estigmatizado não são pessoas, e sim perspectivas que são geradas em situações sociais 
durante os contatos mistos, em virtude de normas não cumpridas que provavelmente atuam sobre o encontro. (GOFFMAN, 1978, p. 177, grifo nosso)

Um dos efeitos desse processo social é a sensação de que os estigmatizados são imperfeitos, não são completamente humanos, gerando uma série de discriminações que reduzem suas chances de vida ao produzir uma série de atributos ao sujeito estigmatizado.

Construímos uma teoria do estigma; uma ideologia para explicar a sua inferioridade e dar conta do perigo que ela representa, racionalizando algumas vezes uma animosidade baseada em outras diferenças, tais como as de classe social. Utilizamos termos específicos de estigma como aleijado, bastardo, retardado, em nosso discurso diário como fonte de metáfora e representação, de maneira característica, sem pensar no seu significado original. (GOFFMAN, 1978, p. 8)

Sobre a população de rua recaem diversos estigmas. A perspectiva do vagabundo está relacionada com as ações desviantes ao trabalho, o que se expressa por meio de julgamentos morais colocando essas pessoas, como improdutivas, inúteis, preguiçosas e vadias. Na condição do louco é jogada a população de rua através do discurso biomédico, que a caracteriza como "doente mental”, anormal e que coloca a mendicância como um produto de "distúrbios da personalidade". São tidos como sujos, tanto quanto as ruas onde se dão as suas existências. A pecha do perigoso incide sobre essas pessoas pelo caminho do discurso jurídico e criminológico que relaciona a mendicância ao crime; ainda que essa lei não mais exista no Código Penal Brasileiro, seu conteúdo ainda permeia o imaginário social, reiterando o estigma. Como coitado dá lugar a práticas religiosas, nas quais o morador de rua é alvo de piedade. (NOGUEIRA, 2008)

A estigmatização e seus efeitos, tais como a discriminação, segregação, marginalização e exclusão, produzem reações na população dita "normal", tais como indiferença, aversão, medo, desrespeito, hostilidade, pressão para dispersão ou recolhimento pelos órgãos públicos, como também, tolerância, solidariedade e ajuda eventual e continua. (ESCOREL, 1999) A indiferença e o preconceito, conforme afirma Luiz Batista Soares (2009), produzem invisibilidade. Sobre a invisibilidade, Soares (2009, p. 331) diz: 
[...] a identidade só existe no espelho, e esse espelho é o olhar do outro, é o reconhecimento dos outros. É a generosidade do olhar do outro que nos devolve a nossa própria imagem ungida de valor [...] Nada somos e não valemos nada se não contarmos com o olhar alheio acolhedor, se não formos vistos, se o olhar do outro não nos recolher e salvar da invisibilidade - invisibilidade que nos anula e que é sinônimo, portanto, de solidão e incomunicabilidade, falta de sentido e valor.

Esta é outra marca importante da população em situação de rua. "Como não escolhem e não fazem as regras do mundo em que vivem” (ESCOREL, 1999, p. 236), não são tidos como “indivíduos” ou, quando reconhecidos como tal, são considerados "deslocados" e "fora do lugar"; isso corrobora com a ideia de Goffman (1978) de que o estigmatizado não se sente - ou não é visto como - completamente humanos.

Cabe ainda registrar que entre os principais atos desviantes produtores de estigmas atribuídos à população em situação de rua estão a privatização do espaço público e o uso de modalidades de sobrevivência que destoam em relação ao mundo do trabalho. A sobrevivência cotidiana dos moradores de rua é realizada em público o que, consoante Escorel (1999), transgride os princípios básicos de organização social que distinguem as esferas e atividades públicas daquelas que são colocadas na ordem do privado; em outras palavras, o que é próprio da rua e próprio da intimidade da casa. O que, de um modo geral, a sociedade entende como ação privada que não pode ser realizada em espaço público, os moradores de rua entendem como satisfação das necessidades vitais. DaMatta (1997) coloca que a oposição casa/ rua $^{3}$ é dinâmica e relativa. O ocupar a rua como espaço de moradia implica uma subversão de tal ordem que a ocupação define o ocupante. Ou seja, a rua é local de indesejável individualização, de luta e de malandragem e os que vivem ali são tidos como desviantes, marginais, meliantes. Ao realizar em público ações que seriam do âmbito do privado, o morador de rua

3 DaMatta (1997) utiliza em seus estudos casa erua como categorias sociológicas. A casa tal qual ele define, "é um espaço de calma, repouso, recuperação e hospitalidade, enfim, tudo aquilo que define a ideia de 'amor', 'carinho', 'calor'humano”. (DAMATTA, 1997, p. 57) Na casa o código fundamenta-se nas relações pessoais estabelecidas por laços familiares. Já a rua é um espaço definido como inverso, ou seja, como algo movimentado, propício a desgraças, semidesconhecido e semicontrolado, povoado pelo perigo. (DAMATTA, 1997) 
passa a ser marcado, identificado pelas características próprias da rua, tais como sujeira e periculosidade. Em relação ao trabalho, não se pode dizer de regularidade e continuidade, o que não permite o atendimento de suas necessidades no âmbito privado.

Em suma, a exclusão social e os estigmas atribuídos à população de rua em função de sua trajetória de vida são processos interligados. Ambos dificultam ou negam o acesso desses aos direitos mais básicos como moradia, saúde, educação, alimentação, etc.; e também pautam as ações direcionadas a esse grupo social, seja para construção de políticas públicas específicas, seja no que concerne às violações de direitos humanos vivenciadas diariamente. Em outras palavras, exclusão social, tanto quanto estigmas, atribuídos às pessoas que vivem parte de suas trajetórias de vida nas ruas são importantes motivadores das ações direcionadas a essa parcela da sociedade.

\section{CARIDADE PARA OS MERECEDORES E SALVAÇÃo PARA QUEM DOA COMIDA}

A busca por comida é um dos eixos centrais através dos quais a rotina na rua se constrói, estimulando os trajetos e deslocamentos dessas pessoas pela cidade e suas potenciais relações. (ESCOREL, 1999; FRANGELLA, 2004) Uma das formas mais comuns de acesso à alimentação se dá pelo que Escorel intitula de redes de sobrevivência que são compostas, em sua maioria, por entidades privadas religiosas que distribuem comida, roupas, prestam auxílio para retirada de documentos, para obtenção de assistência médica, etc. Essas redes são “parte crucial da 'mágica' da sobrevivência dos moradores de rua”. (ESCOREL, 1999, p. 229)

Reiterando os termos simbólicos em que as doações acontecem, a piedade apresenta-se como um dos principais motivadores para a ação de distribuição de comida nessas redes de sobrevivência, marcadamente, como majoritárias, entre as entidades religiosas. Tomemos a piedade como a capacidade de se ter compaixão pelo sofrimento alheio. (KARDEC, 2013) A partir deste sentimento é possível exercitar um dos principais preceitos do Cristianismo: o amor ao próximo, ou seja, fazer ao outro "[...] todo o bem que nos seja possível e que desejaríamos que nos fizessem”. (KARDEC, 2013, p. 379)

Tal como colocado, esse sentimento de piedade vem acompanhado de outro compromisso e dever cristão, a caridade; esta que, a partir de 
concepção cristã-ocidental, tem lugar como um conjunto de ações fundadas em valores como altruísmo e bondade, que objetivam dar aquilo que o outro necessita, seja de forma material, com as práticas de beneficência, isto é, práticas de distribuição de recursos materiais, seja de forma moral. (NEVES, 1999)

É interessante notar que o sentido de piedade e de caridade mudam a partir do entendimento de cada religião acerca de quem é o igual, o irmão, o merecedor de sua ajuda. Por exemplo, o advento do capitalismo e as transformações nos grandes centros urbanos decorrentes da Revolução Industrial e Agrícola acarretaram aumento significativo do número de pessoas empobrecidas, o que tornou a pobreza - e nessa condição, as pessoas em situação de rua - um problema social. A partir daí, as igrejas investem mais na criação de critérios que definiriam os deveres dos fieis frente à pobreza. Chama-se de caridade discriminatória ou seletiva essa interpretação cristã da caridade que a relaciona com o merecimento. (CASTEL, 1998; VISCARDI, 2011)

Nos discursos e práticas dessas instituições religiosas que distribuem comida e prestam outras assistências aos que vivem nas ruas, a questão da caridade discriminatória ou seletiva está presente. Os moradores de rua que frequentam instituições filantrópicas e de assistência social estatal, para sobreviver cotidianamente na rua, devem provar que merecem essa atenção, demonstrando sua passividade e não periculosidade. Segundo Neves (1999), o morador de rua precisa vestir a roupa de "bom pobre", para que seja merecedor daquela ação. Os próprios moradores de rua sabem o que precisam fazer e dominam as condutas “aceitas” por aqueles que doam os alimentos. E valem-se disso para percorrer determinados círculos de relação social.

Ainda nos espaços caritativos de doação de alimentos, a pessoa em situação de rua precisa seguir determinadas regras para conseguir a comida pretendida. O interesse em "civilizar" os moradores de rua surge nas regras para o merecimento da caridade produzida pela caridade seletiva, pela construção de regras de sociabilidade dentro do espaço de doações e pelas pregações e sermões feitos dentro de determinados preceitos religiosos.

As ações de distribuição de comida, seja na rua, seja nas instituições, muitas das vezes são acompanhadas por pregações religiosas, cujos temas, segundo Frangella (2004), são similares nos diferentes grupos. Em sua maioria, são baseados na perspectiva cristã ocidental; são poucos os grupos que seguem outras perspectivas religiosas e que fazem esse tipo de trabalho 
com a população em situação de rua. Mas, mesmo que o grupo não siga os preceitos cristãos, o entendimento das falas que acompanham o trabalho é similar, correspondendo a "[...] um convite ao exorcismo e, consequentemente, à mudança de vida”. (FRANGELLA, 2004, p. 229)

A comida aqui assume o papel de mote para a evangelização, esta que não aparece somente nas pregações, estando presente também nos atos sacros e ritos que envolvem tanto o preparo como o processo de distribuição da comida para os que vivem nas ruas. Segundo Silva e demais autores (2011), a eficácia da evangelização daqueles que vão aos serviços religiosos - seja nas instituições, seja na própria rua - é medida, não apenas pela efetiva conversão do morador de rua em determinada religião, mas também pelo próprio ato de evangelizar o outro e pelo efeito que isso produz: a garantia da sensação de dever cristão cumprido. Todos esses atos de caridade têm como objeto prioritário o merecedor que recebe a comida naquele momento; mas, também, têm como objetivo a salvação eterna daquele que faz a doação.

\section{ALIMENTAÇÃO E A CONSTRUÇÃO DE CORPOS DÓCEIS}

Jogos de força estão presentes no campo da Alimentação e Nutrição quando está em questão a comida distribuída para a população em situação de rua. Nesse microcosmo estão imersos os agentes sociais e as instituições produtoras, reprodutoras e transmissoras de saberes, práticas e modos de ser conformando uma rede, um conjunto de relações objetivas entre posições definidas a partir das diferentes posições ocupadas pelos atores num determinado arranjo na estrutura da distribuição das diferentes espécies de poder ou de capital. No campo religioso, diferentes lógicas regulam a atividade humana, produzindo os sentidos das ações humanas e os sujeitos, subjetividade. Diversos grupos religiosos que estabelecem relações entre si e com os demais, seguem produzindo, transmitindo e reforçando modos de sentir, agir e pensar que repercutem em cada indivíduo em particular e na própria comunidade. Modos de ser, agir e pensar, assimilados e repetidos através do habitus, ou seja, um sistema de disposições duradouras adquiridas pelo indivíduo durante o processo de socialização.

Nesse jogo, a comida distribuída pelas instituições religiosas corresponde a um importante capital simbólico. Ela assume um caráter divino, 
que se manifesta nos atos sacros e ritos religiosos que envolvem o processo de preparo, cocção e distribuição da mesma. Aí, a comida atende não só ao corpo físico, como também à alma, servindo como remédio para as dores da existência e ponto de apoio para aqueles que vivem em situação de rua. A título de ilustração: o Movimento de Amor ao Próximo (AOS OBREIROS..., 2018), em carta destinada aos obreiros das quentinhas, publicada em sua página na internet, coloca que junto à fome, aquela quentinha leva esperança aos “desditosos irmãos” (sic).

Ao realizar em público ações que, segundo as normas hegemônicas, seriam do âmbito privado, a população em situação de rua assume os status do local que ocupa. Se a rua é local da sujeira, da luta, da malandragem, os que ali vivem são tidos como sujos, perigosos, vagabundos, malandros. A população de rua funciona numa lógica diferente das referências culturais hegemônicas e, nesse sentido, as práticas de distribuição de comida a esse grupo social orientam-se pela expectativa de retorno e adequação desse grupo aos padrões sociais dominantes. Isso já está internalizado pelos moradores de rua, visto que, como observa Neves (1999), para conseguir a comida eles precisam demonstrar sua docilidade e não periculosidade. Para chamar a atenção dos doadores é necessário lançar mão de inúmeros recursos, comprovando, assim, que são merecedores daquela ajuda. Os moradores de rua dominam as condutas “aceitas” e valem-se disso para percorrer determinados círculos de doação de comida.

As práticas de distribuição de comida são ritualizadas e cheias de regras, assumindo um importante papel civilizatório desta população. As lógicas presentes no campo religioso são normatizadoras e esquadrinham as subjetividades desse grupo social, induzindo a produção de um sujeito de desejo assujeitado aos interesses dominantes. No jogo de forças, essa relação é ainda mais perversa, pois gera e mantém uma espécie de dependência da população em situação de rua a esses serviços visto que a comida ali oferecida é, em sua maioria, a única refeição que aquele indivíduo fez no dia.

Nessas ações, o discurso religioso da piedade e da caridade modela o estigma do coitado e a ação de distribuição de comida pode ser entendida como estruturada e estruturante de uma não valorização da autonomia da população em situação de rua. Essas práticas, em certa medida, tornam os corpos da população em situação de rua dóceis, um pouco mais disciplinados, encaixando-os em subjetividades predeterminadas, assujeitadas, adequadas 
às lógicas vigentes. Essas instituições, geralmente, não questionam as causas da desigualdade social e da exclusão que levam as pessoas para a rua, elas atuam apenas no sentido de mitigar as consequências e ocupar espaço no jogo político e social.

Sempre há lugar para as contingências; parece-nos, contudo, que o espaço para singularidades é bastante reduzido nessas condições em que praticamente não é possível escolher o que comer, nem o quanto comer ou onde comer e menos ainda quando comer. Tudo é previamente definido pelo doador, ficando as pessoas submetidas às condições e normas das instituições. Ainda assim, a comida é um importante catalisador de vínculos, solidariedade e agregação da população em situação de rua. (ESCOREL, 1999; FRANGELLA, 2004) Isso nos leva à reflexão de que o ato de distribuir a comida, apesar de imbricado ao estigma do coitado, torna-se uma importante ferramenta no combate às violências que a indiferença e a invisibilidade produzem.

Mas não podemos esquecer que a mesma comida que alimenta os corpos biológicos e sociais das pessoas que vivem em situação de rua, alimenta também os corpos institucionais dos grupos que promovem a doação, além de alimentar a alma, o corpo simbólico dos sujeitos que realizam a ação. $\mathrm{Na}$ mesma quentinha que é distribuída na rua cabem os nutrientes, os códigos sociais, os valores morais e a salvação espiritual. Cabe muita coisa numa simples quentinha de alumínio.

\section{REFERÊNCIAS}

AOS OBREIROS das quentinhas. Movimento amor ao próximo, Rio de Janeiro, 2018. Disponível em: http://www.map.org.br/blog/page/9/. Acesso em: 15 out. 2019.

ARENDT, H. A condição humana. Rio de Janeiro: Forense Universitária, 2007.

ARENDT, H. Origens do totalitarismo. São Paulo: Companhia das Letras, 1989.

BAREMBLIT, G. Compêndio de análise institucional e outras correntes: teoria e prática. Rio de Janeiro: Rosa dos Ventos, 1994.

BAUMAN, Z. Vidas desperdiçadas. Rio de Janeiro: Zahar, 2005.

BOURDIEU, P. O poder simbólico. Rio de Janeiro: Bertrand, 1989. 
BOVE, C.; FIGUEIREDO, G. A política nacional para a população em situação de rua: processo e participação. In: GRINOVER, A. P.; ASSAGR, G.; GUSTIN, M. et al. Direitos fundamentais das pessoas em situação de rua. Belo Horizonte: D’Plácido, 2014. p. 421-437.

CARVALHO, M.; LUZ, M.; PRADO, S. Comer, alimentar e nutrir: categorias analíticas no campo da pesquisa científica. Ciências e Saúde Coletiva, Rio de Janeiro, v. 16, n. 1, p. 155-163, 2011.

CASTEL, R. As metamorfoses da questão social. Petrópolis: Vozes, 1998.

CASTRO, E. Vocabulário de Foucault. 2. ed. Belo Horizonte: Autêntica, 2016.

CONTRERAS, J.; GRACIA, M. Alimentação, sociedade e cultura. Rio de Janeiro: Fiocruz, 2011.

DAMATTA, R. A casa e a rua: espaço, cidadania, mulher e morte no Brasil. Rio de Janeiro: Rocco, 1997.

ESCOREL, S. Vidas ao léu: trajetória de exclusão social. Rio de Janeiro: Fiocruz, 1999.

FOUCAULT, M. A hermenêutica do sujeito. São Paulo: Martins Fontes, 2004b.

FOUCAULT, M. Ditos e Escritos: ética, sexualidade e política. 3. ed. Rio de Janeiro: Forense Universitária, 2004a.

FOUCAULT, M. Ditos e Escritos: estratégia, poder-saber. Rio de Janeiro: Forense Universitária, 2012.

FOUCAULT, M. Em defesa da sociedade. São Paulo: Martins Fontes, 2002.

FOUCAULT, M. História da sexualidade: a vontade de saber. Rio de Janeiro: Graal, 1988.

FOUCAULT, M. Microfísica do poder. 8. ed. Rio de Janeiro: Graal, 1989.

FOUCAULT, M. Vigiar e punir: o nascimento das prisões. 35. ed. Petrópolis: Vozes, 2008.

FRANGELLA, S. M. Corpos urbanos errantes: uma etnografia da corporalidade de moradores de rua em São Paulo. 2004. Tese (Doutorado em Ciências Sociais) - Institutos de Filosofias e Ciências Humanas, Universidade Estadual Campinas, Campinas, 2004.

GOFFMAN, E. Estigma: notas sobre a manipulação da identidade deteriorada. Rio de Janeiro: Zahar, 1978.

GUATTARI, F.; ROLNIK, S. Micropolítica: cartografia do desejo. 12. ed. Petrópolis: Vozes, 2013.

KARDEC, A. O livro dos espíritos. Brasília, DF: FEB, 2013.

NAIFF, L. Exclusão social no contexto familiar: uma história de mulheres. In: OLIVEIRA, E. S.; GATTO, M. Programa de jovens mães: uma experiência do feminino. Rio de Janeiro: Imperial Novo Milênio, 2016. p. 19-41. 
NASSER, J. H. O que comem os excluídos? Os diferentes sentidos da comida oferecida para a População em Situação de Rua. 2018. Dissertação (Mestrado em Alimentação, Nutrição e Saúde) - Programa de Pós-graduação em Alimentação, Nutrição e Saúde, Instituto de Nutrição, Universidade do Estado do Rio de Janeiro, Rio de Janeiro, 2018.

NEVES, D. P. Os miseráveis e a ocupação dos espaços públicos. Caderno CRH, Salvador, n. 30-31, p. 111-134, 1999.

NOGUEIRA, F. D. Hóspedes incômodos: estudos sobre moradores de rua no hospital de emergência. 2008. Dissertação (Mestrado em Serviço Social) - Pontifícia Universidade Católica do Rio de Janeiro, Rio de Janeiro, 2008.

OKSALA, J. Como ler Foucault. Rio de Janeiro: Zahar, 2011.

PASTORAL da População de Rua. Arquidiocese de São Sebastião, Rio de Janeiro, 2014. Disponível em: http://arqrio.org/formacao/detalhes/443/pastoral-dapopulacao-de-rua. Acesso em: 3 dez. 2016.

REVEL, J. Dicionário de Foucault. Rio de Janeiro: Forense Universitária, 2011.

SILVA, J. K.; PRADO, S. D.; CARVALHO, M. C. et al. Alimentação e cultura como campo científico no Brasil.Physis: revista de saúde coletiva, Rio de Janeiro, v. 20, n. 2, p. 413-442, 2010.

SOARES, L. E. Juventude e violência no Brasil contemporâneo. In: MAIA, M. (org.). Por uma ética do cuidado. Rio de Janeiro: Garamond, 2009. p. 323-356.

VISCARDI, C. M. Pobreza e assistência no Rio de Janeiro na Primeira República. História, Ciência, Saúde, Rio de Janeiro, v. 18, n. 1, p. 179-197, 2011.

WEBER, M. Ação social e relação social. In: FORACCHI, M. M.; MARTINS, J. S. Sociologia e Sociedade: leituras de introdução à Sociologia. Rio de Janeiro: LTC, 1977. p. 139-144.

WEBER, M. Conceitos sociológicos fundamentais. Covilhã: Lusosofia, 2010.

WOLLZ, L. E.; LEITE, B. F.; FERREIRA, F. R. et al. Alimentação, cidadania e direitos da população em situação de rua: um tema ainda negligenciado. In: PRADO, S. D.; KRAEMER, F. B.; SEIXAS, C. M. et al. Alimentação e consumo de tecnologias. Curitiba: CRV, 2015. p. 434-451. 


\title{
DISCURSOS SOBRE ALIMENTAÇÃO SAUDÁVEL NA EDUCAÇÃO BÁSICA DISSONÂNCIAS OU ALTERNATIVAS DE EDUCAÇÃO ALIMENTAR? ${ }^{1}$
}

\author{
VANESSA NASCIMENTO MOREIRA \\ MARIA CLÁUDIA DA VEIGA SOARES CARVALHO \\ ELIANE PORTES VARGAS \\ FLÁVIA MILAGRES CAMPOS
}

\section{INTRODUÇÃO}

Alimentação sempre foi um tema incluído de algum modo nos currículos das escolas em geral. Os conteúdos sobre alimentação alinham-se às disciplinas de ciências (MOREIRA, 2018) e obedecem a categorias classificatórias que, embora pareçam naturais, são construtos sociais resultantes de acordos sociais entre os agentes e o jogo simbólico presente no campo da educação. Neste capítulo, debatemos os discursos que permeiam a temática alimentação a partir de um livro didático de ciências do $7^{\circ}$ ano do ensino

1 Texto derivado da dissertação de mestrado intitulada Discursos sobre alimentação e o ensino de ciências no contexto da educação básica em um colégio de aplicação do Rio de Janeiro, concluída no Programa de Pós-Graduação em Nutrição do Instituto Josué de Castro de Nutrição, da Universidade Federal do Rio de Janeiro (UFRJ). 
fundamental. Para isto, foi considerada a observação participante em atividades de apoio da disciplina de ciências, com alunos do $6^{\circ}$ e $7^{\circ}$ ano e outros espaços do cotidiano escolar. Foi problematizada uma naturalização do tema alimentação ligado à disciplina de ciências.

O livro didático, ainda que seu uso seja efetivado ou não no cotidiano, foi considerado um potente instrumento para promover a reflexão e estimular a capacidade investigativa do aluno para que este, conforme defende Vasconcellos (1993), assuma a condição de agente na construção de seu conhecimento. Na qualidade de recurso didático, ele é expressão dos acordos sobre a construção de proposta que se dispõe a aplicar métodos científicos, estimulando a análise de fenômenos, o teste de hipóteses e a formulação de conclusões, que por fim, visam seguir o processo de formação dos cidadãos de acordo com os Parâmetros Curriculares Nacionais (PCN). (BRASIL, 1997)

Assim, partimos do pressuposto que a ruptura epistemológica das ciências ditas naturais como a biologia deve ser considerada fruto de convenções e que teve um alto custo, sufocando uma pluralidade epistêmica de temas como a alimentação em uma só disciplina, de ciências. O maior desafio enfrentado na análise documental empreendida esteve em relacionar a prática pedagógica proposta pelo livro didático às possibilidades do contexto escolar, o que justificou a inclusão de observação participante no período de um semestre em atividade de uma disciplina de ciências do segundo segmento do ensino fundamental, neste desenho de estudo. Nas práticas da disciplina foram desenvolvidas atividades na, então em construção, horta escolar, pois os professores e pesquisadores entenderam que o corpo/conteúdo do livro didático se alimenta de modo diferente do corpo/ sujeito que experimenta a temática alimentação, por meio de práticas que têm como ambiente de possibilidades, a horta.

A delimitação do corpus discursivo analisado inscreve-se em um contexto político em que o Ministério da Educação é um dos agentes de uma série de ações promotoras de práticas saudáveis de vida e de Educação Alimentar e Nutricional (EAN). A escola opera como um espaço com potencial para promover saúde e qualidade de vida, influenciando na formação de hábitos alimentares e no desenvolvimento de habilidades para cuidar da saúde e prevenir riscos. Um espaço que permite congregar diferentes atores sociais, desde estudantes e educadores, até suas famílias, profissionais de saúde, 
manipuladores de alimentos, agricultores familiares, vendedores de alimentos e guloseimas da região, enfim, uma gama de agentes sociais articulados em um território legitimado para o debate. (BRASIL, 2015b) Isto corrobora com a participação e influência, direta e indiretamente, de diversos atores sociais nas atividades desenvolvidas nesta escola.

Através da Lei $n^{\circ} 11.947$, a educação alimentar e nutricional deve ser incluída no processo de ensino e aprendizagem, que perpassa pelo currículo escolar, abordando assuntos relacionados à alimentação e nutrição e o desenvolvimento de práticas de alimentação saudável, na perspectiva da Segurança Alimentar e Nutricional. (BRASIL, 2009) Para isto, documentos norteadores, como o Marco de Referência em Educação Alimentar e Nutricional (Marco de EAN) (BRASIL, 2012), orientam ações de educação alimentar de modo contínuo, permanente, transdisciplinar, intersetorial e multiprofissional. Um recurso pedagógico que vem sendo amplamente utilizado para trabalhar essas questões de EAN de forma integrada é a horta escolar, que permite inúmeras possibilidades didáticas, podendo fazer interface, por exemplo, com outras questões climáticas e ambientais. (COELHO; BÓGUS, 2016)

A EAN vem sendo pauta de interesse do governo no desenvolvimento e cumprimento de políticas públicas, com inserção em programas de promoção de saúde, o que vai ao encontro das necessidades da população. A Promoção de Alimentação Adequada e Saudável (PAAS) é uma das diretrizes da Política Nacional de Alimentação e Nutrição (PNAN), e entende-se por estratégias direcionadas a indivíduos e coletividades que promovam a realização de práticas alimentares adequadas às características fisiológicas e socioculturais. Além disto, deve-se incentivar o uso do meio ambiente de maneira sustentável. (BRASIL, 2013) A PAAS destaca também o fato de o alimento ter funções que vão além do aspecto nutricional, que são ricos de significados culturais, comportamentais e afetivos. O alimento deve ser visto não só como um substrato para o organismo, mas também como um objeto carregado de valores simbólicos, o que viabiliza estratégias pedagógicas interdisciplinares, as quais, entre outras contribuições, ampliam as alternativas de comensalidade em diferentes contextos de cenas contemporâneas, além dos espaços escolares.

Nosso intuito nesse capítulo foi o de compreender os discursos envolvendo alimentação que analisamos em práticas no território social de um 
Colégio de Aplicação, assim como em dispositivos educativos específicos, como horta escolar e livro didático, circunscritos arbitrariamente a uma categoria disciplinar de ciências. Para estarmos sensíveis às disposições presentes nas diversas perspectivas discursivas, ancoramo-nos em teorias sociais da Sociologia e da Antropologia que as situam em um jogo simbólico em que cada agente social é dotado de experiências socioculturais específicas que determinam um conjunto de disposições duradouras em habitus. (BOURDIEU, 2013) Esses múltiplos olhares auxiliaram na compreensão de dissonâncias nos discursos, assim como em possibilidades dessas disposições para uma “alimentação saudável” operarem como alternativas educativas no ambiente escolar desta instituição.

\section{O UNIVERSO DO ESTUDO E SEU CAMPO}

A pesquisa de campo focalizou a tríade ensino, pesquisa e extensão e por esta razão foi preciso dimensionar a proposta dos Colégios de Aplicação no Brasil e como eles se diferenciam das demais instituições de ensino.

Sua gênese está relacionada ao Decreto-Lei Federal n 9.053/12 de março de 1946 que determinou a obrigatoriedade de todas as Faculdades de Filosofia manterem Ginásios de Aplicação destinados à prática docente dos alunos dos cursos de Didática. São, originalmente, os objetivos desses Ginásios: prover os recursos com a finalidade de proporcionar a prática de didática apropriada ao ensino; instituir uma casa de ensino modelar para estímulo e emulação de outras do mesmo grau; abrir um campo de estágio evolutivo sob a égide da Faculdade de Filosofia. Sua concepção apoia-se nos seguintes pilares: se constituírem em campo de estágio obrigatório para os licenciandos e o de oportunizarem a experimentação de novas práticas pedagógicas.

O Projeto Político Pedagógico do Colégio de Aplicação da Universidade Federal do Rio de Janeiro (CAp UFRJ), onde desenvolvemos o trabalho de campo, informa que o colégio é um órgão suplementar do Centro de Filosofia e Ciências Humanas (CFCH) e a unidade de Ensino Fundamental e Médio da UFRJ. Sua função acadêmica e institucional apoia-se nos preceitos de ensino, da pesquisa e da extensão. Ademais, vem contribuindo para a formação inicial e continuada de professores a partir do trabalho pedagógico dos alunos de graduação da UFRJ e de instituições federais conveniadas e atuação em conjunto com a Faculdade de Educação. 
A porta de entrada do campo de pesquisa foi o projeto de extensão de educação alimentar e nutricional no Colégio de Aplicação da UFRJ, localizado na Lagoa Rodrigues de Freitas, um dos principais pontos turísticos da cidade do Rio de Janeiro, e escolhido a partir dos seguintes critérios: utilizar livros do Programa Nacional do Livro Didático brasileiro (PNLD); atuar em práticas de horta escolar e desenvolver atividades interdisciplinares. Trata-se de uma instituição de ensino com aproximadamente 70 anos de existência, que tem em seu escopo o fortalecimento da tríade ensino, pesquisa e extensão.

Em termos de filosofia de ensino, o Colégio de Aplicação da UFRJ consolidou seu espaço no cenário educacional do estado do Rio de Janeiro como uma instituição comprometida com a formação crítica de seus alunos, no sentido de que sejam capazes de assumir seu papel na sociedade em que estão inseridos. A defesa dos princípios de autonomia pedagógica e da permanente experimentação de metodologias e estratégias de ensino constituem a identidade do Colégio de Aplicação, que tem como premissa se constituir em espaço preferencial no âmbito da Universidade para a formação dos alunos dos cursos de Licenciatura. Destacamos desde já, a participação desses no planejamento e desenvolvimento de atividades de EAN, educação ambiental e horta escolar durante o desenvolvimento do nosso estudo.

Desde os anos 2000, o Ensino Fundamental foi ampliado para nove anos com a abertura da classe de alfabetização. Aproximadamente 760 alunos do $1^{\circ}$ ano do Ensino Fundamental ao Ensino Médio e cerca de 400 alunos de diversas licenciaturas foram atendidos.

Os alunos ingressam no CAp UFRJ, anualmente, por meio de sorteio público nas séries do ensino fundamental e no primeiro ano do ensino médio incluindo neste último o processo de nivelamento, o que garante uma heterogeneidade do corpo discente em termos de camadas sociais e pertencimento cultural a grupos sociais e comunidades.

Nas últimas três décadas, o CAp UFRJ agregou ao seu projeto político-pedagógico projetos de pesquisa e extensão com a participação de bolsistas de Iniciação Científica, de Extensão e de Iniciação Artística e Cultural sob a orientação dos docentes, o que tem atraído pesquisadores externos para o desenvolvimento de suas pesquisas na área de educação. 


\section{PROCEDIMENTOS TEÓRICO-METODOLÓGICOS DA PESQUISA}

A pesquisa conjugou diferentes estratégias metodológicas apresentadas aqui separadas, mas não realizadas de modo estanque: a) caracterização do universo do estudo; b) descrição do campo da pesquisa; c) análise dos discursos sobre a alimentação, por meio da análise documental proposta por Cellard (2012) - capítulos do livro didático de ciências e documentos norteadores do campo da alimentação e nutrição - entrevistas informais e observação participante (FOOTE-WHYTE, 1980) no espaço escolar. Os informantes-chaves foram professores de ciências do segundo segmento do Ensino Fundamental. O procedimento de observação não esteve restrito às reuniões de planejamento nem às práticas educativas interdisciplinares de apoio às aulas no ensino de ciências, alcançando diversos setores da vivência do cotidiano escolar tais como: reuniões, mutirões para cuidados com horta e alameda frutífera do pátio da escola, palestras e evento comemorativo do dia da alimentação. Um diário de campo foi utilizado para registro dos dados do trabalho de campo. O desenvolvimento do estudo correspondeu ao período entre setembro de 2016 a agosto de $2017 .{ }^{2}$

Os eixos de análise correspondem aos núcleos de sentido identificados nos discursos sobre alimentação presentes no livro didático bem como em práticas de EAN: higiene e alimentação; processo saúde-doença; hábitos alimentares; produção de alimentos; nutrientes; corresponsabilidade e cooperação, e discursos em reprodução.

\section{ANÁlise dOCUMENTAL E OBSERVAÇÃo PARTICIPANTE}

Considerando que este estudo se baseia nas Ciências Sociais e Humanas, a análise documental se mostra um procedimento metodológico pertinente, pois nesta linha de pesquisa as fontes escritas são amplamente utilizadas como base de investigação neste campo. A análise de documentos permite a construção de conhecimento a partir da compreensão dos fenômenos já existentes e como estes vêm se desenvolvendo. A importância do uso de

2 Quantoaos procedimentos éticos, o projeto de pesquisa foi submetido ao Comitê de Ética em Pesquisa do Hospital Clementino Fraga Filho, Faculdade de Medicina da UFRJ, número CAAE: 814653.17.0.0000.5257. 
documentos em pesquisas sobre educação e alimentação é reconhecida, porém, por ser um método exploratório, os problemas que surgem a partir da análise documental devem ser explorados através de outros métodos, de acordo com o questionamento do estudo. Como estamos analisando o discurso sobre alimentação no contexto do Ensino Fundamental, acreditamos que, como estratégia de campo, a observação participante auxilia a entender, na prática, este processo. De acordo com o nosso objeto de pesquisa, não tivemos a pretensão de destacar a análise documental como protagonista do nosso estudo, mas como um recurso metodológico utilizado de modo conjugado a outros na busca por investigar de modo mais amplo a temática alimentação nos processos educativos do campo escolar atrelados ao ensino de ciências.

Contextualizando o universo do livro didático de ciências, nos debruçamos nas diretrizes e parâmetros curriculares no que diz respeito a temas transversais relacionados à saúde e, por consequência, alimentação, fazendo um contraponto com o Programa de Saúde na Escola (PSE), o Marco de EAN e o Guia Alimentar para a População Brasileira (GAPB), o que nos dá subsídio para entender correlações dos discursos sobre alimentação presentes na escola. Dentre os documentos curriculares podemos citar: Parâmetros Curriculares Nacionais, Diretrizes Curriculares, Programa Nacional do Livro Didático, planos de aula, entre outros. Assim, é possível observar se há articulação entre os saberes de educação e alimentação presentes no livro didático e a prática escolar, bem como, as congruências e dissonâncias de ambos os discursos.

Os documentos norteadores de práticas de EAN selecionados foram: PSE, o Marco de EAN e GAPB. As seguintes etapas compõem a análise destes documentos: breve apresentação; elaboração de quadro com as diretrizes e princípios; discussão dos pontos de convergência e definição das principais categorias. O livro didático selecionado para análise documental intitula-se "Projeto Apoema Ciências 7" (versão "Manual do Professor", 448 páginas, 23 capítulos, 2015) e utilizado no ano letivo de 2016. (PEREIRA, A. M. et al., 2015)

Os seguintes critérios nortearam a seleção do livro didático: ter sido selecionado e disponibilizado pelo colégio a partir do Catálogo Nacional do Livro Didático; compor o ensino de ciências e possuir conteúdos explorados nas aulas de apoio; se dirigir aos anos finais do Ensino Fundamental 
$\left(6^{\circ}\right.$ ao $9^{\circ}$ ano); ter sido aprovado pelo Programa Nacional do Livro Didático no ano da pesquisa. Fragmentos do livro de ciências do $7^{\circ}$ ano foram analisados a partir da observação das reuniões de planejamento e das atividades práticas voltadas majoritariamente para o conteúdo do $7^{\circ}$ ano e práticas realizadas na aula de apoio.

A partir das informações geradas na análise preliminar, proposta por Cellard (2012), foram criadas categorias de análise que nortearam a análise relacional entre o plano de aula, o livro didático e as práticas, atrelados aos referenciais teóricos. É importante destacar que não tivemos a pretensão de avaliar se o conteúdo sobre alimentação e nutrição presente no livro está "correto" ou "errado", mas analisar o discurso no próprio tecido documental, unidades, relações e a sua apresentação. Isto é, aproximamo-nos de um referencial de linha francesa sobre o conceito de discurso, em que este é efeito de sentidos compartilhados entre cotextos e o contexto imediato, não existindo "[...] totalmente sem condicionantes lingüísticos ou determinações históricas, nem a língua totalmente fechada em si mesma, sem falhas ou equívocos”. (ORLANDI, 2012, p. 22)

$\mathrm{Na}$ análise desenvolvida, os dados obtidos são compostos pelo corpus da pesquisa, pelas referências bibliográficas e pelo modelo teórico que os sustentam. Assim, como cotextos da análise foram considerados os Parâmetros Curriculares Nacionais, no que tange aos temas transversais de saúde e estudo que problematiza a temática educação alimentar no livro didático (GREENWOOD; FONSECA, 2016) e a proposta do próprio PNLD Ciências. Com base no proposto por De Cicco (2012), vamos considerar no instrumento de coleta as seguintes categorias: a) localização do tema (capítulos), estrutura e formatação (seções e especialistas), conteúdo (como este foi elaborado, sob qual perspectiva), linguagem (call to action, para quem é direcionado, e se faz menção a políticas públicas) e características das ilustrações; b) análise global do livro didático que identificou temas principais associados a quais conteúdos de ciências; c) síntese das observações encontradas no livro didático com o previsto nos PCN; e d) discussão com referencial teórico, PCN e exemplos dos livros.

A observação prévia das práticas de Educação Alimentar direcionadas para o Ensino Fundamental foi um importante recurso metodológico no reconhecimento do campo e aproximação dos diversos atores sociais. As primeiras observações foram realizadas no período de setembro de 2016 
e contribuíram para um "quebra-gelo" entre pesquisadores e atores do campo de pesquisa. Foram realizadas, por um lado, reuniões semanais com docentes - Educação Básica e Ensino Superior -, discentes de Nutrição, grupo de educação ambiental, licenciandos/estagiários de biologia e nutricionistas do Sistema de Alimentação da UFRJ e, por outro, atividades interdisciplinares - dois blocos de quatro encontros semanais de 1h 40min -nas aulas de apoio no Clube de Ciências para alunos convidados pelas professoras de ciências, do $6^{\circ}$ e $7^{\circ}$ ano do Ensino Fundamental. Foram abordadas as temáticas: saúde, alimentação, cultura, educação ambiental, consumo consciente e o conteúdo programático de ciências utilizando recursos midiáticos, horta e oficinas culinárias. Ressaltamos que o intuito desta etapa foi analisar como a abordagem de alimentação articula-se ao ensino de ciências para os alunos dos anos finais do Ensino Fundamental.

A prática dialogada exercida com diferentes agentes sociais, dentro e fora da equipe, permitiu apontar a relevância da inserção da educação alimentar como temática de saúde transversal. Além de alguns desdobramentos: a) significativa troca de saberes e novas parcerias; b) integração universidade-escola; c) construção de uma singela alameda frutífera no campus da escola com o envolvimento de alunos por meio de doações do grêmio estudantil e da Associação dos Pais, Alunos e Amigos do CAp UFRJ (APACAp) - os debates envolvendo a escolha das árvores frutíferas estiveram articulados à iniciativa da horta do clube de ciências; d) construção de um dia da alimentação na escola, nomeado de "Festa Crioula - o nativo nascendo e crescendo na cultura local”, organização legitimada pela direção, com apoio da Associação de Nutrição do Estado do Rio de Janeiro (ANERJ) e Sistema de Alimentação da UFRJ (SIA-UFRJ); e e) convites às nutricionistas-pesquisadoras para realizarem atividades em sala de aula de ciências do $8^{\circ}$ ano. Esses frutos ratificam que um diálogo fluido desde a apresentação da pesquisa durante a entrada do campo, até a realização das culminantes atividades propostas permitiram o surgimento e ampliação de possibilidades na prática de Educação Alimentar no âmbito escolar. Destacando também que encontramos diante de nós, um campo disposto e inclinado a fortalecer a temática alimentação no cotidiano escolar.

Os parâmetros sobre os quais nós nos apoiamos para a realização da observação, tendo por base as Ciências Sociais, valorizam os discursos dos sujeitos, bem como, o processo reflexivo resultante da interação no campo 
entre os agentes sociais e o pesquisador. É importante que o analista esteja ciente da interferência que ele gera no campo e as formas de minimizá-la ou ao menos, considerá-la como parte da análise crítica. (CICCO, 2012) No nosso caso, a interferência gerada pela presença do pesquisador é necessária e benéfica para a construção dos resultados desta pesquisa, uma vez que possibilita entender a dinâmica da comunidade escolar, seu habitus, como as práticas se estruturam e como o discurso é formado. Algo que com apenas a observação ou entrevista não seria possível. O informante-chave, na relação intersubjetiva que se estabelece entre o pesquisador e os agentes sociais da pesquisa, é aquele que facilita e proporciona ao pesquisador informações e(ou) condições especiais para o desenvolvimento das suas observações. (FERNANDES, 2015) O diário de campo se apresenta nessa direção como uma das principais ferramentas do analista durante a observação participante, no qual ele pode tecer anotações das suas impressões e do que ocorre durante a interação com o campo. Esse pode ser associado ao uso de tecnologias, como gravadores e registros em foto. O diário de campo pode compreender a seleção do local de reunião ou atividade, acesso aos dados, os participantes presentes, a produção e análise dos dados mediados pela construção de um roteiro.

Nossa observação no contexto desse colégio incluiu o espaço físico, pois ele reflete as mãos e modos de pensar desta comunidade escolar. Essa escola possui uma estrutura similar a outras instituições de ensino, mas também particularidades. Quanto às instalações físicas, a escola tem dois andares destinados majoritariamente à sala de aulas no segundo andar. O térreo é também composto por salas, auditório, quadra poliesportiva e laboratórios. O local é agradável e propício ao ensino e ao convívio e manifestações culturais a exemplo da parte externa de um muro onde intervenções artísticas de grafite profissional foram observadas. O prédio é antigo e grafites modernos atualizam este passado apontando uma sensibilidade para as artes presente na escola. No interior do prédio também são encontradas intervenções artísticas fruto de trabalho coletivo e didático entre discentes e docentes de um ponto de vista crítico da realidade. A influência midiática exemplifica um tipo de conteúdo que expressa uma relação dinâmica criada pelo conjunto de seus integrantes, recursos e trajetórias particulares. Outra intervenção como as inscrições das assinaturas dos alunos do último ano do ensino médio registram a relação positiva de pertencimento à escola. 
Quanto ao espaço aberto, há área verde composta de árvores e um singelo e charmoso jardim vertical.

Há duas cantinas, localizadas uma exatamente em frente da outra, sendo uma pública e outra privada. A primeira distribui gratuitamente pequenas refeições (lanches rápidos) por meio do Sistema de Alimentação da UFRJ. A segunda é um tipo presente tradicionalmente em colégios da Educação Básica no Brasil com oferta de refeições e alimentos industrializados. Observou-se nas atividades de Educação Alimentar e Nutricional, realizadas na escola, disponibilidade dos funcionários de ambas as cantinas em relação à temática da alimentação, demonstrando predisposição em "melhorar" a qualidade dos itens fornecidos na privada, por exemplo. Enquanto na pública, as cantineiras se mostraram abertas a participar na organização dos itens para atividades culinárias enquanto compartilhavam suas experiências familiares com o cultivo de temperos e seu uso cotidiano.

Conforme a observação transcorria vimos que conjugar a entrevista informal à observação participante seria um bom caminho para o delineamento da pesquisa, uma vez que poderia esclarecer pontos que permaneceram obscuros. Isto porque, apesar da integração e familiarização do pesquisador no campo, algumas informações não se apresentariam por meio da observação. A nossa proposta de entrevista, porém, não se constitui em elaboração de um roteiro/questionário ou qualquer estruturação, mas sim de perguntas que emergiram no contexto da observação no decorrer das práticas observadas e relacionadas a temas que não ficaram totalmente esclarecidos. Dessa forma, procedemos por meio destas perguntas informais na etapa final do processo de observação participante realizando anotações durante ou imediatamente após tê-las concluído. Assim como Foote-Whyte (1980), em sua pesquisa no distrito North End em Boston (chamado pelo autor de "Cornerville"), percebeu que a riqueza de sua pesquisa etnográfica se constituía na observação participante, nós experimentamos, tendo em vista a teoria vivida (PEIRANO, 2014), o potencial deste recurso valioso na produção de reflexões sobre o objeto de estudo. Essa forneceria, em algumas circunstâncias, muito mais respostas sem ser necessário realizar algumas perguntas diretas aos nossos informantes ainda que estes autores não as abandonem por completo, por entenderem o poder complementar que elas fornecem para a pesquisa, quando feitas no momento certo. 


\section{PRINCIPIOS E DIRETRIZES DE DOCUMENTOS OFICIAIS PARA AÇÕES DE EAN}

Consideramos como documentos norteadores, nesta pesquisa, um conjunto de programas e guias que tem como um dos objetivos, orientar os profissionais de saúde que atuam na escola. O PSE foi selecionado, pois é o documento que trata da intersetorialidade entre saúde e educação. O Marco de EAN, por sua vez, representa o documento que norteia as práticas de promoção de alimentação adequada do nutricionista e demais profissionais de saúde. O GAPB torna-se importante, pois sua proposta é de ser a política pública em linguagem acessível para toda a população e é utilizado como material de consulta complementar pelos professores de ciências do CAp UFRJ. (BRASIL, 2011, 2012, 2014)

Em dezembro de 2007 o Decreto $n^{\circ} 6.286$ instituiu o Programa Saúde na Escola (PSE) e suas finalidades, para regulamentar as atividades para a saúde no âmbito escolar. O PSE é resultado de uma parceria entre os Ministérios da Saúde e Educação e entre seus objetivos está a promoção da saúde e da cultura da paz, enfatizando a prevenção de agravos à saúde; articular ações do setor da saúde e da educação, aproveitando o espaço escolar e seus recursos; fortalecer o enfrentamento das vulnerabilidades desta clientela; e incentivar a participação comunitária contribuindo para a formação integral dos estudantes da rede básica. (BRASIL, 2007)

O lançamento, em 2012, do Marco de Referência em Educação Alimentar e Nutricional para as políticas públicas, contribuiu para reafirmar o papel da EAN na escola, pois é um contexto de conhecimento e prática transdisciplinar e multiprofissional, que busca a autonomia do sujeito. O GAPB vai ao encontro do Marco de EAN ao tratar a alimentação não apenas pela ótica de nutrientes e suas quantidades, mas também pelo os modos de comer e a comensalidade. O Quadro 1 compila os princípios e diretrizes destes três documentos norteadores. 
Quadro 1: Relação de princípios e diretrizes dos documentos norteadores, de modo simplificado

\begin{tabular}{|c|c|}
\hline Documentos & Princípios e diretrizes \\
\hline \multirow{8}{*}{ PSE } & $\begin{array}{l}\text { Saúde e educação de modo integral contribuindo para a cidadania e } \\
\text { usufruto dos direitos humanos; }\end{array}$ \\
\hline & $\begin{array}{l}\text { Ampliação intersetorial das ações dos sistemas de saúde e de educação } \\
\text { para atenção integral à saúde de escolares; }\end{array}$ \\
\hline & $\begin{array}{l}\text { Articulação de saberes e participação da comunidade escolar e sociedade } \\
\text { na construção e controle de políticas públicas; }\end{array}$ \\
\hline & $\begin{array}{l}\text { Promoção da saúde e da cultura da paz, prevenindo agravos à saúde e } \\
\text { fortalecendo a intersetorialidade entre saúde e educação; }\end{array}$ \\
\hline & $\begin{array}{l}\text { Articulação das ações do Sistema Único de Saúde* às ações das redes } \\
\text { de educação pública para ampliar o alcance e o impacto de suas } \\
\text { ações, otimizando a utilização dos espaços, equipamentos e recursos } \\
\text { disponíveis; }\end{array}$ \\
\hline & $\begin{array}{l}\text { Fortalecimento do enfrentamento das vulnerabilidades, no campo da } \\
\text { saúde, que prejudicam o desenvolvimento escolar; }\end{array}$ \\
\hline & $\begin{array}{l}\text { Promoção da comunicação, encaminhamento e resolutividade entre } \\
\text { escolas e unidades de saúde, assegurando as ações de atenção e cuidado } \\
\text { sobre as condições de saúde dos estudantes; }\end{array}$ \\
\hline & $\begin{array}{l}\text { Atuar, efetivamente, na reorientação dos serviços de saúde para além de } \\
\text { suas responsabilidades técnicas no atendimento clínico, para oferecer } \\
\text { uma atenção básica e integral aos educandos e à comunidade. }\end{array}$ \\
\hline \multirow{6}{*}{ Marco de EAN } & Sustentabilidade social, ambiental e econômica; \\
\hline & Abordagem do sistema alimentar, na sua integralidade; \\
\hline & $\begin{array}{l}\text { Valorização da cultura alimentar local e respeito à diversidade de opiniões } \\
\text { e perspectivas, considerando a legitimidade dos saberes de diferentes } \\
\text { naturezas; }\end{array}$ \\
\hline & $\begin{array}{l}\text { A comida e o alimento como referências; valorização da culinária } \\
\text { enquanto prática emancipatória; }\end{array}$ \\
\hline & A promoção do autocuidado e da autonomia; \\
\hline & $\begin{array}{l}\text { A Educação enquanto processo permanente e gerador de autonomia e } \\
\text { participação ativa e informada dos sujeitos. }\end{array}$ \\
\hline \multirow{5}{*}{ GAPB } & Alimentação é mais que ingestão de nutrientes; \\
\hline & $\begin{array}{l}\text { Recomendações sobre alimentação devem estar em sintonia com seu } \\
\text { tempo; }\end{array}$ \\
\hline & $\begin{array}{l}\text { Alimentação adequada e saudável deriva de sistema alimentar } \\
\text { socialmente e ambientalmente sustentável; }\end{array}$ \\
\hline & $\begin{array}{l}\text { Diferentes saberes geram o conhecimento para a formulação de guias } \\
\text { alimentares; }\end{array}$ \\
\hline & Guias alimentares ampliam a autonomia nas escolhas alimentares. \\
\hline
\end{tabular}

Fonte: adaptado de Brasil (2007), Brasil (2012) e Brasil (2014). 
Nos três documentos analisados (Quadro 1), é possível observar pontos convergentes entre os seus princípios e diretrizes: integralidade; intersetorialidade; sustentabilidade; cultura alimentar; saberes populares e científicos; autocuidado e cidadania; valor simbólico do alimento. Buscaremos no decorrer das próximas seções analisar como esses princípios aparecem (ou não) no contexto deste estudo.

\section{A CONSTRUÇÃO DE CONFIABILIDADE DO LIVRO DIDÁTICO “PROJETO APOEMA 7"}

Os interesses e motivos que refletem no livro didático são múltiplos devido aos diferentes grupos sociais que o elaboram e selecionam. O livro Projeto Apoema 7 foi escrito por três autoras principais, todas profissionais da educação, com experiência em lecionar para ensino fundamental, médio e superior. Essas autoras estão sujeitas às expectativas, propostas e formato do corpo editorial que considera as bases e diretrizes curriculares, o que segundo Megid-Neto e Fracalanza (2003), exerce enorme influência sobre o livro didático no Brasil, que dificulta a atualização com resultados de pesquisas de Programas de Pós-Graduação. O Governo Federal, por meio do Programa Nacional do Livro Didático (PNLD) é o principal comprador das obras didáticas e, ao definir critérios de avaliação dos compêndios escolares, tem privilegiado mais aspectos gráficos editoriais - diagramação, qualidade do papel, da impressão e da encadernação -, do que aqueles associados a erros conceituais, inadequação metodológica, prejuízos à construção da cidadania, riscos à integridade física dos alunos.

Os editores, submetidos à pressão do principal comprador de seus produtos, sofrem pressão de agentes governamentais com intensa campanha de "marketing" nas escolas, distribuindo exemplares de seus livros aos professores, na expectativa de que o Governo compre futuramente os seus compêndios, à medida que seriam possivelmente indicados pelo corpo editorial. Os editores, juntamente com os autores, apregoam a fidelidade dos seus livros didáticos às diretrizes curriculares oficiais, contudo, essa divulgação se revela uma estratégia de mercado para gerar credibilidade. Este discurso sustentado pelos autores, indicam que o livro apresenta informações científicas atuais e corretas, as quais sofrem pequenas 
adaptações em vista de uma divulgação de cunho didático. (MEGID-NETO; FRACALANZA, 2003)

De acordo com o site oficial da editora responsável pela publicação do livro (EDITORA BRASIL, 2017), esta deu início as suas atividades em 1943, isto é, possui mais de 70 anos de experiência, trabalhando exclusivamente na área de educação em todo o território nacional. Desde 1980 tem parceria com o ensino público. O Projeto Apoema, direcionado para o segundo segmento do Ensino Fundamental foi criado em 2013. O livro tem versão impressa bem como, um serviço de multimídia com um espaço interativo. Portanto, é legitimado como um documento autêntico e de confiabilidade do texto, tendo passado por revisão técnica rigorosa no processo de seleção do PNLD. O processo de seleção do PNLD e o fato de constar no Guia do Livro Didático (GLD), conferem autenticidade e confiabilidade ao texto, segundo os critérios de inclusão e exclusão previstos pelo programa, bem como as etapas de revisão que são realizadas por diversos agentes sociais de diferentes instituições.

Sendo assim, o que nos cabe nessa análise de discurso não se resume a uma interpretação de questões dos textos e cotextos, mas identificar seus limites e mecanismos como parte de um processo de ressignificação. Não há uma verdade oculta atrás do texto, há gestos que o constituem. Segundo Orlandi (2009, p. 26): "Compreender é saber como um objeto simbólico (enunciado, texto, pintura, música etc) produz sentidos. É saber como as interpretações funcionam. Quando se interpreta já se está preso em um sentido”.

\section{O PADRÃO BIOMÉDICO PREVENTIVISTA LIMITA O UNIVERSO DE SIGNIFICAÇÃO}

O discurso de alimentação aparece em diversos capítulos transversalmente ao conteúdo de ciências agrupados pelos temas transversais previstos nos Parâmetros Curriculares Nacionais. (BRASIL, 1998) A escola tem o papel de motivar e capacitar esses jovens para compreensão da saúde como direito e responsabilidade pessoal e social. (BRASIL, 1998) Isso está consoante com o discurso do Marco de EAN e também do Guia Alimentar para População Brasileira, sobre "participação ativa” e autonomia, respectivamente. (BRASIL, 2012, 2014) 
Quadro 2: Comparativo dos temas presentes no livro didático com as orientações dos PCN

\begin{tabular}{|c|c|c|}
\hline \multirow{2}{*}{$\begin{array}{l}\text { Tema } \\
\text { transversal } \\
\text { PCN }\end{array}$} & \multicolumn{2}{|l|}{ Abordagem dos conteúdos } \\
\hline & PCN & Livro didático \\
\hline $\begin{array}{l}\text { Higiene e } \\
\text { alimentação }\end{array}$ & $\begin{array}{l}\text { Água para o consumo humano, processos } \\
\text { de produção e manuseio de alimentos; }\end{array}$ & $\begin{array}{l}\text { Processo saúde-doença; } \\
\text { Durabilidade dos alimentos } \\
\text { (fungos); } \\
\text { Higienização pessoal e de } \\
\text { alimentos; } \\
\text { Micro-organismos; }\end{array}$ \\
\hline $\begin{array}{l}\text { Finalidades de } \\
\text { alimentação }\end{array}$ & $\begin{array}{l}\text { Necessidades corporais, socioculturais e } \\
\text { emocionais; }\end{array}$ & $\begin{array}{l}\text { Importância econômica e } \\
\text { ecológica; } \\
\text { Caráter sociocultural; }\end{array}$ \\
\hline $\begin{array}{l}\text { Estudo do } \\
\text { processo de } \\
\text { nutrição }\end{array}$ & $\begin{array}{l}\text { Ingestão, digestão, absorção, anabolismo, } \\
\text { catabolismo e excreção; }\end{array}$ & $\begin{array}{l}\text { Nutrientes; } \\
\text { Intestino - corpo - } \\
\text { nutrição - bactérias } \\
\text { benéficas; }\end{array}$ \\
\hline $\begin{array}{l}\text { Da produção ao } \\
\text { consumidor } \\
\text { (Do campo à } \\
\text { mesa) }\end{array}$ & $\begin{array}{l}\text { Trabalho humano envolvido, utilização de } \\
\text { aditivos e agrotóxicos e seus efeitos sobre } \\
\text { a saúde dos produtores e consumidores; }\end{array}$ & $\begin{array}{l}\text { Importância econômica e } \\
\text { ecológica; } \\
\text { Produção de alimentos } \\
\text { (agroindústria e agricultura } \\
\text { familiar); }\end{array}$ \\
\hline $\begin{array}{l}\text { Hábitos } \\
\text { alimentares }\end{array}$ & $\begin{array}{l}\text { Geração artificial de “necessidades” } \\
\text { pela mídia e os efeitos da publicidade } \\
\text { no incentivo ao consumo de produtos } \\
\text { energéticos, vitaminas e alimentos } \\
\text { industrializados; }\end{array}$ & $\begin{array}{l}\text { Rotulagem de alimentos } \\
\text { (transgênicos); }\end{array}$ \\
\hline $\begin{array}{l}\text { Obesidade } \\
\text { e carências } \\
\text { nutricionais }\end{array}$ & $\begin{array}{l}\text { Consumo de medicamentos } \\
\text { emagrecedores, uso excessivo de açúcar na } \\
\text { dieta, fator de risco para doenças crônico- } \\
\text { degenerativas. }\end{array}$ & Processo saúde-doença. \\
\hline
\end{tabular}

Fonte: elaborado pelas autoras.

Nos anos finais do Ensino Fundamental, o conteúdo diretamente voltado à alimentação e nutrição aparece no $8^{\circ}$ ano, entretanto, ao analisar o livro didático do $7^{\circ}$ ano foi possível observar também a presença de pontos de ligação entre o conteúdo de ciências e os temas previstos pelos PCN para abordagens que devem aparecer de modo transversal ao currículo escolar, e são estes: higiene e alimentação; processo saúde-doença; hábitos alimentares; produção de alimentos; e nutrientes. 
Ao final do capítulo sobre seres vivos, a seção "Ciências e cidadania" fala sobre a classificação e a preservação da biodiversidade. Esta temática, presente nos discursos das práticas educativas de EAN, tem estreita relação com a produção e variedade de alimentos e a responsabilidade do ser humano na sua preservação. Entretanto, no livro, a biodiversidade fica resumida a queimadas, exploração predatória da madeira e avanços dos garimpos e implantação de agroindústrias que causam desequilíbrios ecológicos, sem problematização em relação ao papel das agroindústrias e a influência destas no consumo alimentar dos escolares e por consequência, seu impacto ambiental.

No "Reino Monera", são dados exemplos de laticínios fabricados a partir de bactérias e a isto credita a importância desses microrganismos no setor econômico e para o setor que formula novos produtos alimentícios, devido aos seus processos químicos que originam em alimentos como coalhadas e vinagres. Também é destacada a presença e importância de bactérias no intestino do ser humano para produção de vitaminas do complexo B. Neste caso, há uma relação com nutrientes. Observamos, como alertam MegidNeto e Fracalanza (2003), que algumas pesquisas produzem extrapolações que se situam ao nível do senso comum e não são sustentadas, nem por evidências empíricas, nem por sólida argumentação.

No capítulo 10, existe uma seção que direciona o aluno-leitor, através de QR code, para uma página de blog colorida destinada ao público infantil com recomendações sobre higiene de alimentos e higiene pessoal como profilaxia, além de conectar com texto de pesquisador do departamento de zoologia de uma universidade pública da Região Sudeste. A seção "Explorando" enfatiza o GAPB quanto à adaptação de recomendações a ferramentas. (BRASIL, 2014) O uso dessas ferramentas de internet está de acordo com os tempos atuais, no qual a internet é representativa no cotidiano de muitos adolescentes, pois estes sujeitos estão imersos na cibercultura própria da geração deles; no entanto, nem sempre esse uso ocorre de modo crítico e de modo ressignificado para a educação no ambiente escolar, com consciência e reflexão. (TONO; FREITAS, 2008)

Na seção "Agora é com você", há uma pergunta sobre leguminosas e sua associação com proteínas, apresentando uma relação entre alimentação e conteúdo de ciências abordado quanto ao aspecto biomédico e processos saúde-doença. Em uma análise comparativa de imagens e textos de livros 
didáticos utilizados em 16 países, Carvalho e demais autores (2008) mostraram a predominância da abordagem biomédica na maioria dos países investigados. Em nossa pesquisa, há similaridade neste quesito, uma vez que, por muitas vezes temas que poderiam ser explorados sob diversos aspectos ficam limitados a questões de caráter preventivo.

Isso pode ser observado, por exemplo, nos capítulos das Unidades 2 e 3 , nos quais os alimentos aparecem como um possível risco à saúde, que apresentam verminoses e o alimento do ser humano está representado como hospedeiro intermediário. Também no capítulo sobre mamíferos, a amamentação, que é um tema importante para gerar um pensamento crítico nos alunos, é tratada sob a ótica biomédica e também sob os riscos que ela pode causar caso a nutriz seja portadora do vírus HIV, não tratando das questões socioculturais que envolvem a amamentação e da subjetividade envolvida neste ato de alimentar um novo ser - ou na escolha de não o fazê-lo e até sua impossibilidade e seus impactos.

Galvão e Silva (2013) ao analisarem a temática amamentação nos livros didáticos nos anos iniciais do Ensino Fundamental, também constataram que havia diversas possibilidades de abordagem transversalmente ao currículo de ciências, que foram subexploradas, como: a degradação ambiental, funções da alimentação e reprodução, questões de corpo humano, seus aparelhos e sistemas, crescimento e desenvolvimento, reconhecimento de alimentos como fonte de energia e manutenção do corpo saudável, higiene pessoal e ambiental, entre outras possibilidades em perspectivas socioculturais envolvidos no ato de amamentar.

O discurso sobre alimentação intimamente relacionado com o processo saúde-doença, também está correlacionado a importância de hábitos de higiene pessoal e alimentar. Isto pode ser exemplificado quando o livro traz questões como a doença botulismo. Esta é uma das poucas vezes em que o livro se posiciona ou estimula a reflexão, nos remetendo aos princípios incutidos no Guia alimentar (BRASIL, 2014), quando traz à tona uma questão atual sobre o direito às informações obrigatórias em rotulagem de alimentos e suas tensões no jogo de poder (PEREIRA, 2017) e também sobre a disseminação desses saberes para a comunidade.

Finalizando esse grupo de sentidos saúde-doença, cuja ênfase recai sobre a prevenção, destacamos e analisamos o texto complementar que ilustra essa disposição. No livro ele intitulava-se $O$ chazinho da vovó é bom, mas 
cuidado!. Os saberes milenares sobre plantas medicinais, cultura herdada de índios também evocam a cultura popular, mas que em nossa análise é inferiorizada pelos autores quando comparada ao saber biomédico. Esse padrão de "prevenção" e a "questão de fatores nutricionais e antinutricionais” estão apresentados como superiores em relação à cultura popular que, por sua vez, é marginalizada pela hegemonia do discurso preventivo como alternativa de menor valor, até perigosa. Essa, que seria uma oportunidade para ampliar o universo da alimentação, silencia-o.

Nesta perspectiva, entende-se que os sentidos podem ser lidos num texto mesmo não estando ali, sendo de suma importância que se considere tanto o que o texto diz quanto o que ele não diz, ou seja, o que está implícito, que não é dito, mas é significado. Pensar o imaginário linguístico é, então, 'tirar as consequências do fato de que o não dito precede e domina o dizer'. (PÊCHEUX, 1988, p. 291)

\section{ESPAÇOS INTERDISCIPLINARES COM ALIMENTAÇÃO EM PRÁTICAS PEDAGÓGICAS}

Os muros do CAp UFRJ operam também como um espaço para inscrição de mensagens dos alunos e neles pudemos registrar discursos mandatórios em grafites associados à alimentação nas paredes internas, usando os verbos conjugados no imperativo como "hidrate-se!” e “evite açúcar”, por exemplo - estes acompanhados por desenhos livres complementares. Do mesmo modo, a diretoria reforçou o espaço da horta escolar, sendo este um espaço plural e multidisciplinar, já existente no interior do Clube de Ciências, sob supervisão dos professores dessa disciplina.

Apesar de a horta escolar ser o fio condutor das práticas, outros recursos foram selecionados tanto nas atividades da aula de apoio quanto nos eventos que aconteceram concomitantemente para toda a comunidade escolar. Foi possível observar a riqueza da área comum da escola, o pátio, pois ali é o local de fornecimento dos lanches rápidos onde há diferentes espaços para comensalidade. Nos corredores que dão acesso às salas de aula, nos deparamos com um cartaz que dizia: "Você sabe de onde vêm os alimentos que você come?”. Com isto, percebemos que a estrutura física também fala, reverberando a voz da comunidade escolar. 
Durante as reuniões de planejamento das aulas de apoio no espaço denominado Clube de Ciências, sempre quando tratávamos a possibilidade de os alunos pesquisarem por conta própria os assuntos da aula de apoio, era citado o GAPB, bem como experiências que envolviam culinária. Os docentes estavam ávidos por compartilhar suas experiências práticas de sala de aula conosco (nutricionistas pesquisadores). O uso do GAPB vai ao encontro de uma valorização da alimentação saudável reforçada em ações de EAN em nosso estudo, assim como em outros. (PRADO et al., 2016)

Apesar de o GAPB ter sido o documento mais utilizado e(ou) citado nas práticas no período que estivemos neste ambiente escolar, por ser didático e diretamente relacionado à alimentação, outros materiais similares foram selecionados, como o livro Alimentos regionais brasileiros (BRASIL, 2015a), manuais sobre horta escolar e Plantas Alimentícias Não Convencionais (PANC) também foram consultados e apresentados aos estudantes. O uso de material com linguagem objetiva e visualmente estimulante foi crucial para as atividades na aula de apoio para o ensino fundamental. Quando se tratava de estimular a pesquisa pelos próprios alunos, era citado o uso da internet agregado aos métodos tradicionais de ensino, como uma forma de promover atividades lúdicas, dinâmicas e prazerosas. A internet representou uma das fontes de pesquisa para criação de um questionário pelos próprios alunos sobre a vivência de horta dos atores sociais da escola, materializando-se na captação de entrevistados e realização de entrevistas pelos próprios estudantes.

Outro recurso com livre acesso e disponível na escola, porém não utilizado durante as aulas de apoio são os livros didáticos e paradidáticos, uma vez que não atendem as expectativas e desenhos pedagógicos das professoras. Essa conclusão corrobora com o encontrado por Silva e Marques (2016) numa pesquisa em um centro urbano do Maranhão, sobre a seleção e uso do livro didático pelos professores, na qual foi observada uma insatisfação com relação à qualidade no que se refere ao excesso de conteúdos e a falta de contextualização, de relação com o cotidiano.

As aulas de apoio congregavam eventos como "Festa Crioula” e outros recursos como a exposição de curtas-metragens e vídeos didáticos sobre alimentação, uso de banner exposto no pátio, próximo às cantinas, que relatava as experiências exitosas realizadas no Sistema de Alimentação da UFRJ em ações de EAN em parceria com os graduandos de nutrição desta 
universidade. A diversidade de materiais didáticos utilizados ao longo das atividades revelou um anseio por abarcar diferentes metodologias de modo a tornar o conteúdo mais próximo à realidade cotidiana da escola.

\section{UM DISCURSO DE CORRESPONSABILIDADE E COPARTICIPAÇÃO}

Nesses espaços, o discurso sobre alimentação que se manifestou durante toda a pesquisa de campo, esteve relacionado à ideia de corresponsabilidade e coparticipação, que remete a proposta dos princípios e diretrizes de EAN de ser multiprofissional e dialógica. O querer fazer em conjunto, distribuindo as responsabilidades com equidade, no contexto do Colégio de Aplicação, potencializa os sentidos da colaboração. Há uma disposição para estas atividades interdisciplinares. Isso pode ser atribuído à valorização da tríade ensino, pesquisa e extensão já mencionada, que é própria desta escola que por ser de referência e vinculada à uma universidade pública na educação básica se ocupa das três vertentes chave (ensino, pesquisa e extensão). Apesar do cerne da pesquisa estar voltado para a demanda da escola em trabalharmos dentro do setor de ciências, e ele ter se tornado nosso cenário principal de atuação, nossa presença era sempre atravessada por reuniões e propostas mais ampliadas para toda a comunidade escolar, por meio da Diretoria Adjunta de Licenciatura, Pesquisa e Extensão (DALPE), que mesmo ciente da nossa atuação na horta escolar do clube de ciências, mostrou interesse em desenvolver hortas nos espaços coletivos da escola e se prontificou em contatar, juntamente conosco, o Grêmio Estudantil e a APACAp para parcerias e doações de material para uma singela alameda frutífera. Esse movimento sobressaltou dois aspectos: o envolvimento dos pais e o capital simbólico que a horta escolar representa. Neste último, percebemos que a maior visibilidade da horta era cara para a comunidade escolar, uma vez que a horta já existente ficava numa área externa nos fundos do Clube de Ciências.

O papel de mediação da diretoria em nos apresentar aos pais responsáveis pela Associação possibilitou compreendermos o papel destes no cotidiano escolar e seu impacto indireto em ações de EAN. Os pais têm voz ativa e são participantes das decisões da escola, assim como também cooperam com suas habilidades. É importante compreender as subjetividades inerentes a 
estes sujeitos. Para entender a função destes atores na comunidade escolar, cabe compreender tudo que forma o discurso de um sujeito: sua história, a linguagem e a sua singularidade. (ORLANDI, 2001) Esses sujeitos não têm vínculo direto com a escola, porém seu interesse surge pela preocupação com o ambiente social escolar que seus filhos estão inseridos, compreendendo que este espaço é responsável também pela formação de hábitos, como os alimentares, coletivamente. Com base nesse contexto, os pais tem a responsabilidade de opinar sobre as decisões da escola, se posicionando sobre propostas para novas incursões e comprometimento com a educação dos alunos.

Foi na reunião com o APACAp e a DALPE que materializamos os anseios dos primeiros e pudemos conhecer seus representantes. A proposta naquele momento era unir esforços e habilidades de acordo com a formação profissional e(ou) aptidões de cada um para construção de um evento com várias atividades. Pais paisagistas poderiam auxiliar na estética, por exemplo, a professora de artes poderia auxiliar com a carpintaria, assim como uma figura representativa da comunidade que presta pequenos serviços para a escola. A entrada nunca é simples, é movida por um interesse em conhecer o projeto envolto por curiosidade e grau de envolvimento de tempo e ação exigidos.

O grêmio estudantil também esteve presente na reunião, na qual se mostravam interessados e dispostos a ajudar na arrecadação do dinheiro. As propostas de atividades que interessavam os alunos do grêmio eram variadas e estavam sendo contempladas regularmente pelo Ciclo de Debates organizado pela escola. Entre os temas de interesse estavam alimentação e sexualidade. Na reunião também foi vista a possibilidade de doação de vasos para terra e plantio. Durante as sugestões, exemplos do cotidiano emergiam, assim como o projeto "Doe sua orquídea", que acontece pelos arredores da zona sul do Rio de Janeiro. Isso destaca também como o entorno da escola influencia as práticas internas. $\mathrm{Na}$ alimentação, o mesmo acontece, quando consideramos que a região turística possui diversas opções de estabelecimentos comerciais de alimentação, oferecendo além das duas cantinas do próprio colégio, opções e variedades de produtos e preparações alimentícias que influenciam na formação e consolidação dos gostos alimentares desses adolescentes.

A interação com os pais no cenário escolar é valorosa para o Colégio de Aplicação, que, fazendo um paralelo com os documentos oficiais de 
EAN, representam a sociedade civil. Este contato entre responsáveis dos discentes e corpo técnico-administrativo da escola foi cultivado, e sermos inseridos nesta parceria dialógica, também reforça que o discurso sobre alimentação também está envolvido com a perspectiva de colaboração, de trabalho em conjunto com pesquisadores. No processo de comunicação e mobilização na educação alimentar e nutricional, é necessária esta formação de vínculo entre os diferentes sujeitos que integram o processo. (BRASIL, 2012) Entendemos que essa é uma disposição para uma socialização.

Essa disposição dos agentes sociais ampliou o espaço horta escolar do Clube de Ciências para outros dois espaços do Colégio de Aplicação com alameda frutífera e vasos suspensos nos muros. Fomos junto ao grêmio estudantil para sensibilizar os alunos do ensino médio a ajudarem na aquisição dos insumos necessários para este projeto da alameda frutífera. Os alunos se mostraram interessados, levantaram questionamentos sobre alimentação e relatos pessoais, em especial sobre hábitos alimentares. A DALPE também entrou em contato com a APACAp para contribuir com doações.

Assim como ocorrido com a APACAp, o vínculo estabelecido com os representantes do Grêmio Estudantil foi intermediado pela diretoria de extensão, e foi importante para que pudéssemos compreender as singularidades deste coletivo. Os representantes discentes têm um papel fundamental em perpetuar a ideia de corresponsabilidade e participação nas tomadas de decisão e propostas da escola.

\section{A HORTA COMO UM “CONTRADISCURSO DA HEGEMONIA DA ALIMENTAÇÃO"}

Retomando nossa relação com os atores envolvidos com o ensino de ciências, na primeira reunião de planejamento das atividades junto ao setor de ciências, em setembro de 2016, estiveram presentes as professoras de ciências do $6^{\circ}$ e $7^{\circ}$ ano do Ensino Fundamental, a licencianda de biologia integrante do grupo de Educação Ambiental para Professores da Educação Básica -, e mestrandas de nosso grupo de pesquisa. O ponto central desse diálogo foi a horta escolar do clube de ciências, iniciada em julho de 2016 e em fase de construção. As professoras destacaram a importância da horta escolar como um "contradiscurso da hegemonia da alimentação", palavras proferidas por uma delas, o que nos mostra uma preocupação da equipe de 
explorar a horta para além de questões meramente nutricionais e conteudistas, e aponta um olhar mais ampliado sobre alimentação e seu impacto na sociedade. Isso também demonstra um discurso de resistência às grandes indústrias alimentícias, ao passo que reproduz os discursos das políticas públicas, aqui já citadas, no cotidiano escolar. Há uma ideia de corresponsabilidade em estimular um pensamento crítico dos alunos quanto à alimentação.

Um anseio das professoras de ciências desde o início foi para a elaboração de uma ficha técnica para cada planta da horta com as informações científicas de botânica, propriedades nutricionais e uso culinário, como uma forma de agregar e preservar todo o conhecimento diverso e legitimado representado pelos grupos de pesquisa da UFRJ presentes nesse projeto, como o setor de nutrição e o setor de educação ambiental. Cabe aqui destacar, que até o final das atividades conjuntas, estas fichas técnicas estavam em construção e não foram finalizadas, o que demonstra que o próprio campo se mostra dinâmico e criativo, trazendo necessidades dos sujeitos envolvidos no decorrer das atividades, que podem ou não ser congruentes com as expectativas iniciais.

Outra expectativa na qual a professora demonstrou entusiasmo por sua concretização, era para a confecção de uma composteira com articulação com o Sistema de Alimentação da UFRJ no fornecimento de material orgânico, como cascas de frutas. Isto demonstra que a equipe, apesar de se concentrar no Clube de Ciências, via a necessidade de envolver outros atores da escola nas práticas, trazendo a questão de pertencimento da horta por toda comunidade escolar, que é estimulado também nas políticas públicas de um fazer integral em prol da comunidade. Outra questão que as professoras encontravam no dia a dia era quanto à manutenção da horta e a dificuldade de parceiros para auxiliar no cuidado da horta.

Essa primeira reunião foi crucial para definição de como atuaríamos na escola e também calibrou o olhar sobre como a pesquisa abordaria alimentação no ensino de ciências. Ressaltamos aqui que a alimentação foi tratada no ensino de ciências por uma demanda do corpo escolar que nos direcionou para este setor, e também, por meio da análise do livro didático, foi possível perceber que havia fortes relações entre alimentação e ciências, que poderiam ser mais exploradas, sendo assim, por essas diversas disposições fomos destinados ao ensino de ciências. Foram definidas que as atividades seriam realizadas na aula de apoio (às quintas-feiras de $13 \mathrm{~h}$ 30min 
às $15 \mathrm{~h} 10 \mathrm{~min}$ ), em bloco de quatro aulas consecutivas, em datas pré-definidas, com estimativa de dez alunos que em sua maioria possuem dificuldades de interpretação do conteúdo de ciências e na escrita. Portanto, a proposta de construção da ficha técnica pelos alunos seria uma forma de trabalhar a escrita.

A proposta inicial da aula de apoio com a ferramenta da horta escolar era de ser um projeto-piloto, onde todo o processo seria avaliado para que no ano subsequente os demais professores fossem convidados a participar da horta, bem como de outras atividades. Após essa reunião, cada membro da equipe ficou com uma incumbência. As professoras de ciências deveriam enviar o planejamento das aulas, nós do Laboratório Digital de Educação Alimentar e Nutricional (LADIG'E) ${ }^{3}$ e a equipe de Educação Alimentar para Professores da Educação Básica (EAPEB) ficamos responsáveis por enviar propostas de atividades que dialogassem entre si.

Essa reunião inicial foi marcada pela troca mútua de saberes e experiências numa construção coletiva das práticas educativas. Foram levantadas questões da horta escolar, sobre como foi sua implantação, ao passo que também tratamos da matriz de Horta Escolar (SUpHORTA) feita pelo LADIG'E em 2014 na comunidade Pavão-Pavãozinho que despertou curiosidade das professoras sobre esse relato de experiência. As professoras de ciências se mostravam sempre abertas e entusiasmadas com este projeto. E toda a equipe valorizou o planejamento como estratégia de estreitamento de laços entre a equipe multidisciplinar.

A definição da horta como ambiente de aprendizagem para tratar de temas de alimentação, educação ambiental e ciências, mostra que o setor se importa em criar mecanismos de aprendizagem que envolva a prática e gerem a autonomia do indivíduo. Outro ponto levantado pelas professoras é com relação à dificuldade na escrita dos alunos participantes da aula de apoio, portanto, indicaram fazermos alguma pesquisa sobre as espécies da horta que contribuíssem para: escrita, raciocínio e mobilização da comunidade escolar. Nas reuniões de planejamento iniciais, quando o grupo ainda

3 O Laboratório Digital de Educação Alimentar e Nutricional (LADIG'E) do Instituto de Nutrição Josué de Castro da Universidade Federal do Rio de Janeiro é um núcleo de estudos e ações de educação alimentar e nutricional que tem como objetivo a construção de saberes e materiais didáticos e técnicos com acesso livre, em versão digital e ecológica. 
estava conhecendo o modo de cada um trabalhar, havia um interesse grande na ligação entre o conteúdo de ciências, alimentação e educação ambiental.

Os professores se prontificaram a dividir os custos com os insumos de oficinas culinárias que não puderam ser adquiridas diretamente com o Sistema de Alimentação, por questões de logística. A disponibilidade dos docentes em ratear o custo das atividades também é um modo de mostrar a unidade de equipe e a ideia de corresponsabilidade ao invés de prestação de serviço, marcando essas interações na e com a comunidade escolar.

A participação dos discentes nas aulas de apoio não é coercitiva, mas sim, estimulada e orientada para os alunos nos quais foram identificadas algumas fragilidades, como por exemplo, dificuldade na escrita. Isto mostra uma interdisciplinaridade dentro do ensino de ciências, uma vez que há uma preocupação com a redação, poder de argumentação e uso da língua portuguesa dos alunos. Para isto, na primeira aula de apoio, os alunos foram convidados a realizar uma pesquisa sobre as experiências dos atores sociais da escola quanto as suas experiências pessoais com a horta escolar e transcrever as respostas e suas principais impressões. Isto retoma a questão da visibilidade das nossas atividades, a partir do diálogo com a comunidade escolar, que em sua maioria trouxe um discurso sobre saberes populares, hábitos familiares e cultura. Essa visibilidade foi importante, pois demonstrou uma cooperação dos atores sociais da escola com a formação desses alunos e também porque permitiu atenuar esse "silenciamento" da horta de ciências, por ser esta, localizada em um espaço pouco visível, e pelas atividades internas não reverberarem por toda a escola.

Compreendendo a horta escolar como um importante dispositivo para promover a integração da comunidade escolar, foi possível perceber que isto se concretizou durante as aulas de apoio, à medida que os discentes se envolviam com os conteúdos dados a partir do momento que havia uma ligação com a horta escolar, que é prática e é palpável. Assim como constataram Coelho e Bógus (2016), nossa experiência promoveu a produção de sentidos que dizem respeito ao aprendizado de modo horizontal e à troca de saberes, à vivência prática de conteúdos curriculares de ciência e a ideia de corresponsabilidade e coparticipação no cuidado com a comunidade. A horta escolar é, portanto, uma estratégia pedagógica que possibilita o pensar em conjunto sobre as relações do ser humano com a alimentação. As diversas experiências que tivemos ao longo desse período, 
demonstraram uma disposição para a corresponsabilidade em práticas de educação alimentar e nutricional.

\section{CONSIDERAÇÕES FINAIS}

Uma afirmação categórica manifestada durante os momentos informais no Clube de Ciências expressa a ruptura entre livro didático e práticas didáticas: “Mas a gente não usa [o livro]”, relata uma das professoras ao serem indagadas sobre este exemplar. A postura das professoras em não terem o livro didático como um dos principais norteadores de suas práticas corrobora com o que foi concluído por Gramowski, Delizoicov e Maestrelli (2017) que, ao analisarem os GNLD de Ciências de 1999 a 2014, notaram que livro didático configura-se, apenas, como uma alternativa no desenvolvimento do trabalho em sala de aula e cabe a cada professor avaliar o modo de planejar e estruturar os conhecimentos relativos a cada segmento do ensino fundamental, considerando seus alunos e a realidade em que vivem. Assim como a pesquisa desses autores, também percebemos ao analisar o livro didático, que apesar de os documentos oficiais (como o Guia do Livro Didático) apontarem para um ensino de ciências articulado com conhecimentos de diferentes áreas, a maioria dos livros didáticos em uso no contexto escolar, apresentam conteúdos organizados de maneira fragmentada, o que limita as opções dos professores em práticas.

Foi possível perceber pontos de congruência entre práticas de EAN e o conteúdo do livro didático. No contexto do ensino de ciências durante as aulas de apoio, as ações de Educação Alimentar e Nutricional vão ao encontro das políticas públicas de saúde. Harrison (2005) destaca em seu estudo a importância do professor incorporar o rótulo de educador em saúde à sua identidade profissional. A autora evidencia essa necessidade, após analisar a produção científica sobre educação em saúde e constatar que estas raramente estão presentes na literatura do ensino de ciências, mas sim, na área da saúde.

Compreendemos que esses discursos que reproduzem os documentos oficiais são norteadores de práticas, mas não as definem. Há uma disposição por classificação no GAPB, por exemplo, no que se refere à divisão dos alimentos por categorias quanto ao tipo de processamento, do mesmo modo que o livro didático expressa dicotomias de diversos tipos, 
a relação do homem com o alimento é vista também pela classificação de "pode" ou "não pode", a higienização em correta e incorreta. Por isto, a alimentação estar inserida no ensino de ciências aparece de modo tão naturalizado, porque existe um mecanismo semelhante de classificação. Esse discurso sobre alimentação também tem o intuito de seguir uma classificação de acordo com as políticas públicas, por isto conceitos como "interdisciplinaridade", "sustentabilidade", "integralidade" migravam de um pra outro no cotidiano escolar. Isto é exatamente o que encontramos nos documentos oficiais aqui relatados (BRASIL, 2012, 2014), e o que podemos ressaltar é que o poder simbólico existente nos discursos das políticas é tão presente, que a escola acaba por reproduzir, muitas vezes, sem plena consciência do que se trata, tornando-se prescritivo, mesmo quando pretende refutar isto.

Esse caráter reprodutor da escola é discutido por Bourdieu (2013), e ir contra isto demanda um esforço considerável. Um exemplo disto ocorreu na Festa Crioula, na qual na proposta inicial, o objetivo central era promover ações interdisciplinares, mas no dia do evento, houve uma setorização de cada atividade dificultando, quase impedindo um diálogo entre os atores sociais. Apesar de essa festa ter tido bons frutos quanto à oportunidade de discutir de modo mais específico sobre as questões que envolvem a alimentação, os discursos de integralidade, transversalidade e interdisciplinaridade não fizeram sentido nos discursos como ação prática.

Assim, a partir da imersão no campo de pesquisa por meio da observação participante de práticas de Educação Alimentar e Nutricional, foi possível constatar que existe um conhecimento prévio sobre alimentação por parte dos atores sociais da escola e que o modo de conduzir essa temática de modo transversal ao currículo escolar no ensino fundamental, permeia as diretrizes e princípios dos documentos oficiais de alimentação e nutrição. De igual modo, ao analisar o livro didático de ciências, vislumbramos diversas possibilidades de diálogo deste conteúdo com a temática alimentação, considerando as questões como a cultura local e a subjetividade que o ato de comer carrega, além do caráter biomédico e normativo.

Os discursos sobre alimentação observados não são homogêneos, porém, possuem um elo entre si. O livro didático é uma expressão das políticas públicas de educação e currículo, pois são aprovados pelo Plano Nacional do Livro Didático, e apesar de não ser o principal documento norteador 
das práticas no ensino de ciências, o discurso presente no livro aparece também nas práticas, associados a outras fontes de consulta. $\mathrm{O}$ discurso está presente estruturalmente de forma naturalizada e propaga-se nos diversos espaços. Este discurso se apresenta com tendência a uma alimentação prescritiva, mas ao mesmo tempo com uma intenção de seguir diretrizes como integralidade, autonomia, cultura local e sustentabilidade.

Quanto ao livro didático selecionado, analisar o tema da alimentação inserido no contexto do ensino de ciências permitiu concluir que a temática não se esgota no ensino de ciências. Foi possível desnaturalizar essa relação da alimentação com o ensino de ciências, abrindo alternativas de EAN com matemática, geografia ou português. Se no conteúdo curricular, que já está consolidado a associação direta com as ciências biológicas, há dissonâncias e caminhos a explorar, nas demais disciplinas curriculares há diversas possibilidades de concretização da alimentação como um tema de fato transversal ao currículo escolar.

A interdisciplinaridade agrega valor e permite a construção mútua de saberes na prática, pois o sentido de cooperação que perdurou durante todas as etapas da pesquisa, corrobora com a ampliação dos elos entre agentes da escola e a comunidade escolar. Estabelecer um espaço para horta escolar foi propício para atividades de EAN, o que minimiza as dificuldades normalmente encontradas quando o ambiente ou atores sociais não são favoráveis às práticas de promoção de saúde, possibilitando que os esforços estejam voltados para o planejamento minucioso das ações multidisciplinares envolvendo saúde.

Podemos afirmar que a análise documental do livro didático de ciências do $7^{0}$ ano evidenciou convergência com princípios e diretrizes de políticas públicas sobre alimentação saudável, reproduzidos com um caráter prescritivo e dispostos com naturalidade, que se contrapunham a uma autonomia, pressuposto de uma proposta crítica apresentada como base. Por outro lado, analisamos discursos militantes contra os alimentos ultraprocessados e todo seu arsenal industrial, que com docilidade obedeciam ao GAPB. O espaço da horta se mostrou um universo interdisciplinar de significação com limites ampliados para a experiência cotidiana na escola. $\mathrm{O}$ conteúdo de alimentação saudável do livro é incorporado nos discursos como verdade e condição única para se ter um corpo saudável, o que produz efeitos de responsabilização e obediência. 
Por fim, concluímos que os diversos documentos e práticas analisados sobre alimentação produzem discursos ora dissonantes em relação aos conteúdos estruturados por Políticas Públicas, ora produzindo sentidos e alternativas às regras inalcançáveis dessas diretrizes políticas, e, nessa condição, esses discursos com os dois efeitos formam cidadãos no espaço de experiências socializadas entre professores e alunos, como a da horta, onde se configuram novos saberes que dão sentido do coletivo, a cada um desenvolvendo potencial para construir uma espécie de "respiradouros da escola". Compreender o olhar da escola sobre a alimentação, permite compartilhar sentidos coletivos no planejamento de ações de Educação Alimentar e Nutricional, contribuindo para uma autonomia dos sujeitos articulada com o "bem" coletivo como um conhecimento que perpassa a trajetória de vida de todo ser humano.

\section{REFERÊNCIAS}

BOURDIEU, P. A economia das trocas simbólicas. São Paulo: Perspectiva, 2013.

BRASIL. Decreto n ${ }^{0}$ 6.286, de 5 de dezembro de 2007. Institui o Programa Saúde na Escola - PSE, e dá outras providências. Diário Oficial da União: seção 1, Brasília, DF, 6 dez. 2007.

BRASIL. Decreto-Lei no 9.053, de 12 de março de 1946. Cria um ginásio de aplicação nas Faculdades de Filosofia do país. Diário Oficial da União: seção 1, Brasília, DF, 14 mar. 1946.

BRASIL. Lei $\mathrm{n}^{\circ} 11.947$, de 16 de junho de 2009. Dispõe sobre o atendimento da alimentação escolar e do Programa Dinheiro Direto na Escola aos alunos da educação básica; altera as Leis nos 10.880, de 9 de junho de 2004, 11.273, de 6 de fevereiro de 2006, 11.507, de 20 de julho de 2007; revoga dispositivos da Medida Provisória $\mathrm{n}^{0}$ 2.178-36, de 24 de agosto de 2001, e a Lei $\mathrm{n}^{0} 8.913$, de 12 de julho de 1994; e dá outras providências. Diário Oficial da União: seção 1, Brasília, DF, 17 jun. 2009.

BRASIL. Ministério da Saúde. Alimentos regionais brasileiros. 2. ed. Brasília, DF: Ministério da Saúde, 2015a.

BRASIL. Ministério da Saúde. Caderno temático SAN e PAAS versão preliminar. Brasília, DF: Ministério da Saúde, 2015b. Disponível em: http://dab.saude.gov.br. Acesso em: 24 fev. 2016.

BRASIL. Ministério da Saúde. Guia alimentar para a população brasileira. 2. ed. Brasília, DF: Ministério da Saúde, 2014. 
BRASIL. Ministério da Saúde. Passo-a-passo: programa de saúde na escola. Brasília, DF: Ministério da Saúde, 2011.

BRASIL. Ministério da Saúde. Política Nacional de Alimentação e Nutrição. Brasília, DF: Ministério da Saúde, 2013.

BRASIL. Ministério do Desenvolvimento Social e Combate à Fome. Marco de referência de educação alimentar e nutricional para as políticas públicas. Brasília, DF: Ministério da Saúde, 2012.

BRASIL. Secretaria de Educação Fundamental. Parâmetros curriculares nacionais: terceiro e quarto ciclos do ensino fundamental: introdução aos parâmetros curriculares nacionais. Brasília, DF: Ministério da Educação: Secretaria de Educação Fundamental, 1998.

BRASIL. Secretaria de Educação Fundamental. Parâmetros curriculares nacionais: apresentação dos temas transversais, ética. Brasília, DF: Ministério da Educação: Secretaria de Educação Fundamental, 1997.

CARVALHO, G. S.; DANTAS, C.; LUZI, D. et al. Comparing health education approaches in textbooks of sixteen countries. Science Education International, London, v. 19, n. 2, p. 133-146, 2008.

CELLARD, A. A análise documental. In: POUPART, J.; DESLAURIERS, J.P.; GROULX, L.; LAPERRIÈRE, A.; MAYER, R; PIRES, A. A pesquisa qualitativa: enfoques epistemológicos e metodológicos. 3. ed. Petrópolis: Vozes, p. 295-314, 2012. p. 2095-314.

CICCO, R. R. Potencialidades e limites do ensino das doenças sexualmente transmissíveis: um estudo qualitativo na perspectiva socioantropológica. 2012. Dissertação (Mestrado em Ensino em Biociências e Saúde) - Fundação Oswaldo Cruz, Instituto Oswaldo Cruz, Rio de Janeiro, 2012.

COELHO, D. E. P.; BÓGUS, C. M. Vivências de plantar e comer: a horta escolar como prática educativa, sob a perspectiva dos educadores. Saúde e sociedade, São Paulo, v. 25, p. 761-770, 2016.

EDITORA BRASIL. Brasília, DF, [2---]. Disponível em: http//:www.editorabrasil. com.br. Acesso em: 7 ago. 2017.

FERNANDES, F. M. B. Considerações Metodológicas sobre a Técnica da Observação Participante. In: MATTOS, R. A.; BAPTISTA, T. W. F. Caminhos para análise das políticas de saúde. Porto Alegre: Rede UNIDA, 2015. p. 487-503.

FOOTE-WHYTE, W. Treinando a observação participante. In: ZALUAR, A. (org.). Desvendando máscaras sociais. Rio de Janeiro: Francisco Alves, 1980. p. 77-86.

GALVÃO, D. M. P. G.; SILVA, I. A. Abordagem da amamentação nos primeiros anos do ensino fundamental. Revista da Escola de Enfermagem, São Paulo, v. 47, n. 2, p. 477-85, 2013. Disponível em: www.ee.usp.br/reeusp/. Acesso em: 17 ago. 2017. 
GRAMOWSKI, V. B.; DELIZOICOV, N. C.; MAESTRELLI, S. R. P. O PNLD e os guias dos livros didáticos de ciências (1999 - 2014): uma análise possível. Ensaio Pesquisa em Educação em Ciências, Belo Horizonte, v. 19, p. 1-18, 2017. Disponível em: http://dx.doi.org/10.1590/1983-21172017190110. Acesso em: 12 dez. 2017.

GREENWOOD, S. A.; FONSECA, A. B. Espaços e caminhos da educação alimentar e nutricional no livro didático. Ciência \& Educação, Bauru, v. 22, n. 1, p. 201-218, 2016.

HARRISON, J. K. Science education and health education: locating the connections. Studies in Science Education, Abingdon, v. 41, n. 1, p. 51-90, 2005.

MEGID-NETO, J.; FRACALANZA, H. O livro didático de ciências: problemas e soluções. Ciência \& Educação, Bauru, v. 9, n. 2, p. 147-157, 2003. Disponível em: http://dx.doi.org/10.1590/S1516-73132003000200001. Acesso em: 17 ago. 2017.

MOREIRA, V. N. Discursos sobre alimentação e o ensino de ciências no contexto da educação básica em um colégio de aplicação do Rio de Janeiro. 2018. Dissertação (Mestrado em Nutrição Humana) - Instituto de Nutrição Josué de Castro, Universidade Federal do Rio de Janeiro, Rio de Janeiro, 2018.

ORLANDI, E.P. Análise de discurso: princípios \& procedimentos. 8. ed. Campinas: Pontes, 2009. 100p

ORLANDI, E. P. Discurso e Texto: formulação e circulação dos sentidos. Campinas: Pontes, 2001.

ORLANDI, E. P. Discurso em análise: sujeito, sentido, ideologia. Campinas: Pontes, 2012 .

PÊCHEUX, M. Semântica e discurso: uma crítica à afirmação do óbvio. Campinas: UNICAMP, 1988.

PEIRANO, M. Etnografia não é método. Horizontes Antropológicos, Porto Alegre, v. 20 , n. 42 , p. $377-391,2014$

PEREIRA, A. B. Do controverso "chão da escola” às controvérsias da etnografia. Horizontes Antropológicos, Porto Alegre, v. 23, n. 49, p. 149-176, 2017.

PEREIRA, A.M.; SANTANA, M.; WALDHELM, M. Projeto Apoema ciências 7. 2 ed. São Paulo: Editora do Brasil, 2015. 448p.

PRADO, B. G.; FORTES, E. N. S.; LOPES, M. A. L. et al. Ações de educação alimentar e nutricional para escolares: um relato de experiência. Demetra, Rio de Janeiro, v. 11, n. 2, p. 369-382, 2016. Disponível em: 10.12957/demetra.2016.16168. Acesso em: 1 out. 2017.

SILVA, M. C. G.; MARQUES, C. V. V. C. O. O livro didático de ciências: concepções de seleção e utilização por professores da zona urbana da cidade de Codó-MA.

Pesquisa em Foco, São Luís, v. 21, n. 1, p. 46-66. 2016. 
TONO, C. C. P.; FREITAS, M. C. D. A Cibercultura e o papel do professor da escola pública na aprendizagem humana mediada pelo computador e internet para além do domínio técnico. Cadernos da Escola de Educação e Humanidades, Curitiba, v. 3, p. 1-18, 2008.

VASCONCELLOS, C. S. Construção do conhecimento em sala de aula. São Paulo: Libertad, 1993. 



\section{SOBRE OS AUTORES}

\section{Alessandra de Figueredo Porto}

Doutoranda do Programa de Pós-Graduação em Comunicação e pesquisadora associada ao Laboratório de Comunicação, Arte e Cidade e do Laboratório de Comunicação, Cidade e Consumo da Faculdade de Comunicação Social da Universidade do Estado do Rio de Janeiro. Professora do IBMEC do Rio de Janeiro, Brasil.

\section{Ana Gretel Echazú Böschemeier}

Doutora em Antropologia pela Universidade de Brasília. Professora do Departamento de Antropologia da Universidade Federal de Rio Grande do Norte, Brasil.

\section{Anna Silvia Penteado Setti da Rocha}

Doutora em Radiologia Odontológica pela Universidade Estadual de Campinas com Pós-doutorado em Bioética pela Pontifícia Universidade Católica do Paraná. Professora da Universidade Tecnológica Federal do Paraná, Brasil. 


\section{Carolina Daltoé da Cunha}

Mestranda do Programa de Pós-Graduação em Alimentação, Nutrição e Saúde com bacharelado e licenciatura em Geografia pela Universidade Federal Fluminense e integrante do Núcleo de Estudos sobre Alimentação e Cultura (NECTAR) do Instituto de Nutrição da Universidade do Estado do Rio de Janeiro, Brasil.

\section{Carolina Muniz Pessanha D'Almeida de Brito}

Graduanda no Curso de Nutrição do Instituto de Nutrição Josué de Castro da Universidade Federal do Rio de Janeiro, Brasil.

\section{Caroline Filla Rosaneli}

Doutora em Ciências da Saúde pela Pontifícia Universidade Católica do Paraná com Pós-Doutorado pela Cátedra Unesco de Bioética da Universidade de Brasília. Docente visitante no Curso de Doutorado de Humanidades da Universidade Católica de Moçambique. Professora do Programa de Pós-Graduação em Bioética e vice-líder do Grupo Pesquisa Saúde Pública, Bioética e Direitos Humanos da Pontifícia Universidade Católica do Paraná, Brasil.

\section{Cintia Sanmartin Fernandes}

Doutora em Sociologia Política pela Universidade Federal de Santa Catarina com Pós-Doutorado pela Escola de Comunicação da Universidade Federal do Rio de Janeiro e pelo Programa de Comunicação e Semiótica da Pontifícia Universidade Católica de São Paulo. Professora do Programa de Pós-Graduação em Comunicação e líder do grupo de pesquisa Comunicação, Arte e Cidade (CAC) da Faculdade de Comunicação Social da Universidade do Estado do Rio de Janeiro, Brasil.

\section{Cristiane Marques Seixas}

Doutora em Teoria Psicanalítica pela Universidade Federal do Rio de Janeiro, Professora Adjunta no Programa de Pós-Graduação em Alimentação, Nutrição e Saúde e pesquisadora do Núcleo de Estudos sobre Cultura e 
Alimentação (NECTAR) do Instituto de Nutrição da Universidade do Estado do Rio de Janeiro, Brasil.

\section{Daniela Menezes Neiva Barcellos}

Doutora pelo Programa de Pós-graduação em Alimentação, Nutrição e Saúde e pesquisadora do Núcleo de Estudos sobre Cultura e Alimentação (NECTAR) do Instituto de Nutrição da Universidade do Estado do Rio de Janeiro. Bolsista de Pós-Doutorado no Programa de Pós-graduação em Nutrição e pesquisadora do Laboratório Digital de Educação Alimentar (LADIG’E) do Instituto de Nutrição Josué de Castro da Universidade Federal do Rio de Janeiro, Brasil.

\section{Eliane Portes Vargas}

Doutora em Saúde Coletiva pelo Instituto de Medicinal Social da Universidade do Estado do Rio de Janeiro. Pesquisadora Titular e Docente dos Programas de Pós-Graduação em Ensino em Biociências e Saúde do Instituto Oswaldo Cruz e em Saúde Pública da Escola Nacional de Saúde Pública da Fundação Oswaldo Cruz. Líder do grupo de pesquisa CORPUS Estudos Socioculturais sobre Corpo, Gênero, Reprodução e Sexualidade da Universidade Federal Rural do Rio de Janeiro e pesquisadora do Núcleo de Estudos sobre Cultura e Alimentação (NECTAR) do Instituto de Nutrição da Universidade do Estado do Rio de Janeiro, Brasil.

\section{Ewerton Reubens Coelho-Costa}

Doutorando em Sociologia pela Universidade Estadual do Ceará e membro do Grupo de Pesquisa Gestão do Turismo e da Hospitalidade nos Territórios Instituto Federal do Ceará - Campus Fortaleza, Brasil.

\section{Fabiana Bom Kraemer}

Doutora em Alimentação, Nutrição e Saúde pela Universidade do Estado do Rio de Janeiro modalidade sanduíche na Universitat Rovira i Virgili, Espanha. Professora Adjunta no Programa de Pós-Graduação em Alimentação, Nutrição e Saúde e pesquisadora no Núcleo de Estudos Sobre Cultura e 
Alimentação (NECTAR) do Instituto de Nutrição da Universidade do Estado do Rio de Janeiro, Brasil.

\section{Flávia Milagres Campos}

Doutora pelo Programa de Pós-Graduação em Alimentação, Nutrição e Saúde do Instituto de Nutrição da Universidade do Estado do Rio de Janeiro e docente da Escola de Nutrição da Universidade Federal do Estado do Rio de Janeiro, Brasil.

\section{Francisco Romão Ferreira}

Doutor em Ciências pela Escola Nacional de Saúde Pública com pós-doutorado em Ensino de Biociências na Saúde pelo Instituto Oswaldo Cruz. Professor Adjunto e Pesquisador no Programa de Pós-Graduação em Alimentação, Nutrição e Saúde e Líder do Núcleo de Estudos sobre Cultura e Alimentação (NECTAR) do Instituto de Nutrição da Universidade do Estado do Rio de Janeiro, Brasil.

\section{Jesica Carreras}

Consejo Nacional de Investigaciones Científicas y Técnicas (CONICET) e Instituto Interdisciplinario de Tilcara, Facultad de Filosofía y Letras, Universidad de Buenos Aires, Buenos Aires, Argentina.

\section{Julia Horta Nasser}

Doutoranda do Programa de Pós-Graduação em Alimentação, Nutrição e Saúde e integrante do Núcleo de Estudos sobre Alimentação e Cultura (NECTAR) do Instituto de Nutrição da Universidade do Estado do Rio de Janeiro, Brasil.

\section{Laura Pey Consejo}

Consejo Nacional de Investigaciones Científicas y Técnicas (CONICET) e Instituto de arqueología, Facultad de Filosofía y Letras, Universidad de Buenos Aires, Buenos Aires, Argentina. 


\section{Letícia da Silva Coutinho}

Mestranda do Programa de Pós-Graduação em Nutrição da Universidade Federal do Rio de Janeiro, Brasil.

\section{Lucrecia Raquel Greco}

Doutora em Antropología Social pela Universidad de Buenos Aires. Professora Visitante do Departamento de Antropologia da Universidade Federal de Bahia, Brasil.

\section{Maria Cláudia da Veiga Soares Carvalho}

Doutora em Saúde Coletiva pelo Instituto de Medicina Social da Universidade do Estado do Rio de Janeiro. Professora Adjunta do Programa de Pós-graduação em Nutrição e líder do Laboratório de Ações de Educação Alimentar e Nutricional em Versão Digital (LADIG'E) do Instituto Josué de Castro de Nutrição da Universidade Federal do Rio de Janeiro. Pesquisadora do Núcleo de Estudos sobre Cultura e Alimentação (NECTAR) e do Programa de Pós-Graduação em Alimentação, Nutrição e Saúde do Instituto de Nutrição da Universidade do Estado do Rio de Janeiro, Brasil.

\section{Nathália César Nunes}

Doutoranda do Programa de Pós-Graduação em Nutrição em Saúde Pública e colaboradora do Grupo de Pesquisa em Alimentação e Cultura da Universidade de São Paulo, Brasil.

\section{Rodrigo Alvarenga}

Doutor em Filosofia pela Universidade Federal de Santa Catarina, com estágio de pesquisa na Université Paris 1 (Panthéon-Sorbonne). Professor do Programa de Pós-Graduação em Direitos Humanos e Políticas Públicas. Coordenador do Grupo de pesquisa em Direitos Humanos, Saúde Mental e Políticas Públicas e membro do Grupo de pesquisa Direitos Humanos e Fluxos Migratórios da Pontifícia Universidade Católica do Paraná, Brasil. 


\section{Shirley Donizete Prado}

Doutora em Saúde Coletiva pelo Instituto de Medicina Social da Universidade do Estado do Rio de Janeiro. Professora Titular no Programa de Pós-Graduação em Alimentação, Nutrição e Saúde. Pesquisadora líder do Núcleo de Estudos sobre Cultura e Alimentação (NECTAR) do Instituto de Nutrição da Universidade do Estado do Rio de Janeiro e Coordenadora da Rede Ibero-Americana de Pesquisa Qualitativa em Alimentação e Sociedade (REDE NAUS).

\section{Silvana Silveira Campos}

Doutoranda pelo Programa de Pós-Graduação em Alimentação, Nutrição e Saúde e integrante do Núcleo de Estudos sobre Alimentação e Cultura (NECTAR) do Instituto de Nutrição da Universidade do Estado do Rio de Janeiro, Brasil.

\section{Talita Prado Barbosa Roim}

Doutora pelo Programa de Pós-Graduação em Ciências Sociais Universidade Estadual Paulista Júlio de Mesquita Filho. Participa como pesquisadora no Grupo de Estudos Consumo, Cultura e Alimentação (GECCA). Vinculada como pós-doutoranda e professora colaboradora ao Programa de Pós-Graduação em Antropologia Social da Universidade Federal de Goiás, Brasil.

\section{Tatyana Scheila Friedrich}

Doutora em Direito com pós-doutorado na Fordham University, NY. Docente do Programa de Pós-Graduação em Direito e líder do Núcleo de Pesquisa em Direito Público do Mercosul (Nupesul) da Universidade Federal do Paraná, Brasil.

\section{Vanessa Nascimento Moreira}

Mestre em Nutrição pelo Programa de Pós-Graduação em Nutrição do Instituto Josué de Castro de Nutrição da Universidade Federal do Rio de Janeiro, Brasil. 


\section{Verônica Oliveira Figueiredo}

Doutora em Ciências Farmacêuticas e docente do Instituto de Nutrição Josué de Castro da Universidade Federal do Rio de Janeiro, Brasil. 
$E_{\text {ste livro foi produzido em formato } 170 \times 240 \mathrm{~mm} \text { e utiliza as tipografias }}$ Calluna e Barlow Condensed, com miolo em papel Alta Alvura $75 \mathrm{~g} / \mathrm{m}^{2}$ e capa em Cartão Supremo $300 \mathrm{~g} / \mathrm{m}^{2}$, impressa na I. Bigraf. Tiragem: 300 exemplares. 


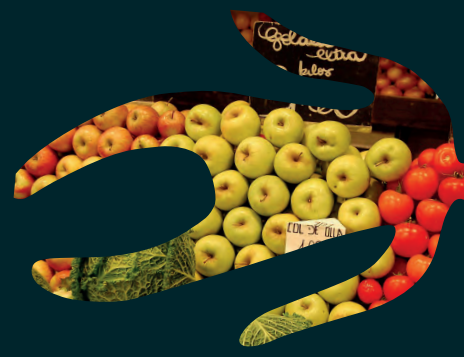

Comensalidades em Trânsito reúne estudos cujo olhar está voltado para o caráter provisório dos códigos culturais que vamos assumindo em função de determinados contextos históricos. Consumir uma ou outra comida, em grupo ou sozinho, postando ou não nas redes sociais faz parte de um modo inerente ao espírito humano de afirmar e de negar sentidos sempre em fluxo. São abordagens que investem na desnaturalização da alimentação e do corpo, reorientando o foco dos debates para tensões presentes nas relações sociais cotidianas marcadas por moralizações e jogos de poder. Ao mesmo tempo, conformam perspectivas inovadoras dirigidas aos processos de construção das identidades sociais e de subjetividades, conferindo visibilidade aos nexos entre essas temáticas complexas e a comensalidade em diferentes cenas contemporâneas.
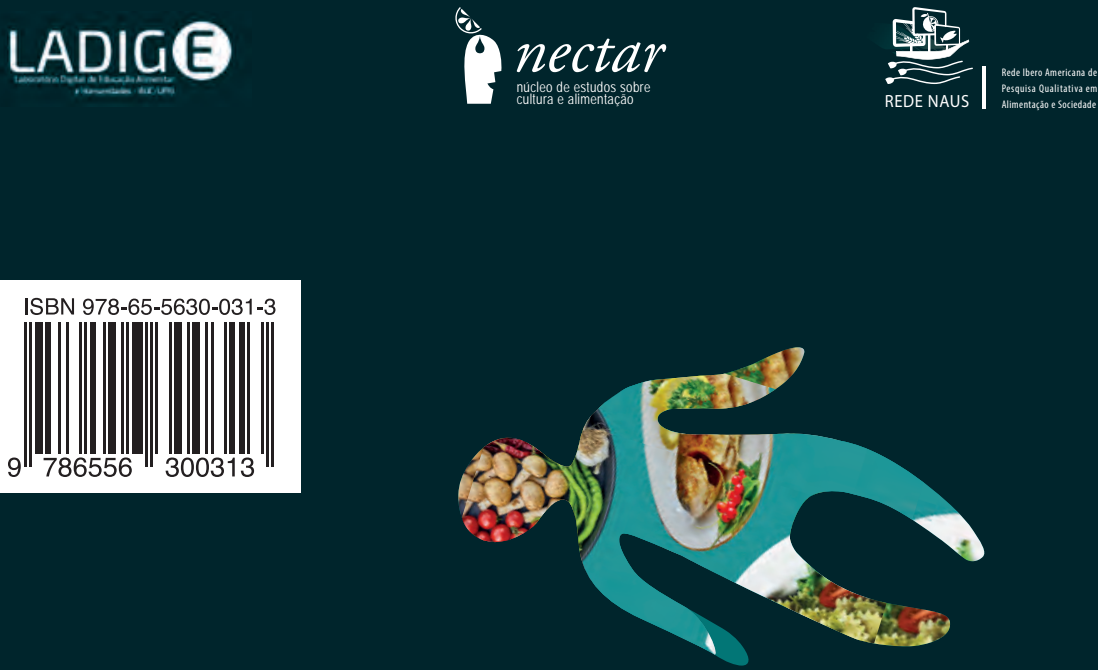